\title{
Environmental Management Performance Report May 2000
}

Prepared for the U.S. Department of Energy

Assistant Secretary for Environmental Management

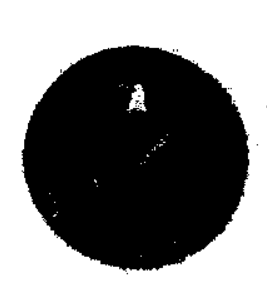

\section{United States \\ Department of Energy \\ Richland Operations Office \\ P.O. Box 550 \\ Richland, Washington 99352}

Approved for Public Release; Further Dissemination Unlimited 


\section{CORRESPONDENCE DISTRIBUTION COVERSHEET}

Author

G. J. McCleary, FDH

(D. M. Eder, 376-0755)

CONTRACT NO. DE-AC06-96RL13200 -

Subject:
Addressee

G. M. Bell, RL

Correspondence No.

FDH-9553093 R58

PERFORMANCE REPORT - MAY 2000

\section{DISTRIBUTION}

\begin{tabular}{|c|c|c|c|c|c|}
\hline Name & Location & w/att & Name & Location & w/att \\
\hline Correspondence Control & A3-01 & $\mathrm{x}$ & \multirow{2}{*}{\multicolumn{3}{|c|}{ Bechtel Hanford, Inc. }} \\
\hline Central Files & B1-07 & $x$ & & & \\
\hline DOE/RL Reading Room & $\mathrm{H} 2.53$ & $\mathrm{x}$ & M.C. Hughes & H0-09 & $\mathrm{x}$ \\
\hline DPC & H6-08 & $\mathrm{x}$ & J. L. Walsh & H0.11 & $x$ \\
\hline Hanford Technical Library & P8-55 & $\mathrm{x}$ & & & \\
\hline & & & \multicolumn{3}{|l|}{ DynCorp } \\
\hline Fluor Hanford & & & & & \\
\hline E. S. Aromi, Jr. & H6-10 & $\mathbf{x}$ & M. D. Dallas & H5. 33 & $x$ \\
\hline B. A. Austin & H8-67 & $\mathrm{x}$ & \multicolumn{3}{|c|}{ Pacific Northwest National Laboratory } \\
\hline M. A. Baumann & $\mathrm{R} 3-61$ & $\mathbf{x}$ & & & \\
\hline P. S. Blaír & R3-11 & & R. L. Dirkes & K6-75 & $\mathrm{x}$ \\
\hline S. W. Bork & B3-70 & $\mathbf{x}$ & E. Maloney & $\mathrm{K} 9-26$ & $\mathrm{x}$ \\
\hline N. C. Boyter & L5-66 & $\mathrm{x}$ & M. A. Williams & K1-74 & $\mathrm{x}$ \\
\hline M. E. Buxbaum & B3.53 & $\mathrm{x}$ & & & \\
\hline P. A. Callendar & GS. 51 & & & & \\
\hline D. B. Cartmell & L5-66 & & & & \\
\hline D. M. Eder $/ 20$ & B3-53 & $\mathrm{x}$ & & & \\
\hline J. W. Hales & Al-14 & $\hat{x}$ & & & \\
\hline B. J. Hanni & H6-05 & $\ddot{x}$ & & & \\
\hline R. D. Hanson & H5-20 & $\mathbf{x}$ & & & \\
\hline X. J. Hubert & H5-25 & $\mathrm{x}$ & & & \\
\hline G. W. Jackson & TS-50 & $\mathbf{x}$ & & & \\
\hline R. G. Jones & R3-11 & $\mathrm{x}$ & & & \\
\hline D. S. Ketly & G3.23 & $\mathrm{x}$ & & & \\
\hline L. M. Kinsey & L0-32 & $\ddot{x}$ & & & \\
\hline D. B. Klos & $\mathrm{N} 2-51$ & $\mathrm{x}$ & & & \\
\hline L. E. Maiden & B3.53 & $\mathrm{x}$ & & & \\
\hline G. J. McCleay & B3-53 & $x$ & & & \\
\hline K. A. McGinnls & G5.51 & $\mathbf{x}$ & & & \\
\hline T. L. Moore & G1.32 & & & & \\
\hline L. J. Olguin & HS-24 & & & & \\
\hline D. P. Olson & B3-53 & $\mathbf{x}$ & & & \\
\hline E. W. Penn, Jr. & H8-63 & & & & \\
\hline S. S. Prevette & H8-67 & & & & \\
\hline J. A. Rampon & R3-11 & $\mathbf{x}$ & & & \\
\hline D. L. Renberger & H6-10 & $\mathrm{x}$ & & & \\
\hline D. B. Van Leuven & $\mathrm{H} 5 \mathrm{r} 2 \mathrm{O}$ & $\mathrm{x}$ & & & \\
\hline R. B. Wilkinson & R3.11 & $x$ & & & \\
\hline PLNG File/LB & B3-53 & & & & \\
\hline
\end{tabular}


May 10,2000

Mr. G. M. Bell, Director

Analysis and Evaluation Division

U.S. Department of Energy

Richland Operations Office

Post Office Box 550

Richland, Washington 99352

Dear Mr. Bell:

CONTRACT NO. DE-AC06-96RL13200 - ENVIRONMENTAL MANAGEMENT PERFORMANCE REPORT - MAY 2000

Attached is DOE/RL-99-83, Revision 4, "Environmental Management Performance Report May 2000," which was delivered to the U.S. Department of Energy, Richland Operations Office on May 2, 2000, and in bound copy on May 5, 2000. Please note that this issue includes quarterly data regarding the status of Environmental Management (EM) performance measures. Also included is performance data associated with the draft EM Management Commitments provided to Fluor Hanford on April 24, 2000. Site Planning and Integration will continue to work with your staff regarding any additional enhancements to the report.

The monthly Environmental Management Performance Report is available on the Internet. The website address is http://www.hanford.gov/empr/toc.htm.

If you have any questions, no longer require the report in hard copy, or have problems accessing it electronically, please contact Mr. D. M. Eder of my staff at 376-0755.

Very truly yours,

G.J. McCleary, Director Uery

Project Controls

cas

Attachment

DOE-HQ - R. Lightner

RL - S. A. Sieracki w/o att.

V. Skinner w/o att. 
DOE/RL-99-83

Revision 4

\section{Environmental Management Performance Report May 2000}

www.hanford.gov/empr/toc.htm

Prepared for the U.S. Department of Energy

Assistant Secretary for Environmental Management

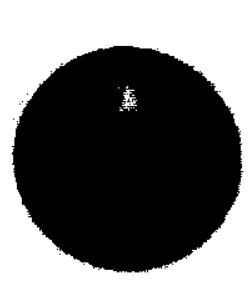

United States

Department of Energy

Richland Operations Office

P.O. Box 550

Richland, Washington 99352 
TRADEMARK DISCLAIMER

Reference herein to any specific commercial product, process, or service by trade name, trademark, manufacturer, or otherwise, does not necessarlly constitute or imply its endorsement, recommendation, or favoring by the United States Government or any agency thereof or its contractors or subcontractors.

This report has been reproduced from the best available copy. Available in paper copy and microfiche.

Available electronicalty at http://muw.doe.gov/bridge. Available for a processing foe to the U.S. Department of Energy and its contractors, in paper, from:

U.S. Department of Energy

Office of Scientific and Technical Information

P.O. Box 62

Oak Ridge, TN 37831-0062

phone: $865-576-8401$

fax: 865-576-5728

email: reports@adonis.osti.gov(423) 576-8401

Available for sale to the public, in paper, from:

U.S. Department of Commerce

National Technical Information Service

5285 Port Royal Road

Springfield, VA 22161

phone: 800-553-6847

fax: 703-605-6900

email: orders (1) ntis.fedworld.gov

online ordering: http://www.ntis.gov/ordering.htm 


\section{RELEASE AUTHORIZATION}

Document

DOE/RL-99-83, Revision 4

Number:

Document Title: Environmental Management Performance Report April 2000

\section{This document, reviewed in accordance with DOE Order 241.1, "Scientific and Technical Information Management," and DOE G 241.1-1, "Guide to the Management of Scientific and Technical Information," does not contain classified or sensitive unclassified information and is:}

\section{APPROVED FOR PUBLIC RELEASE}

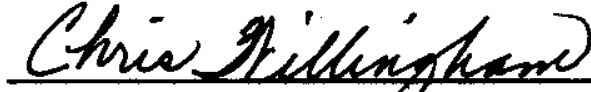

Christino Willingham

Lockheed Martin Services, Inc.

Document Control/nformation Clearance
$5 / 4 / 00$

Approval Date

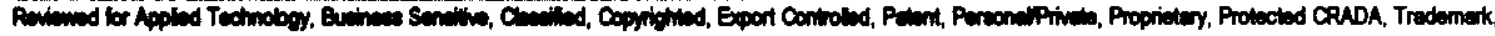

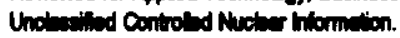

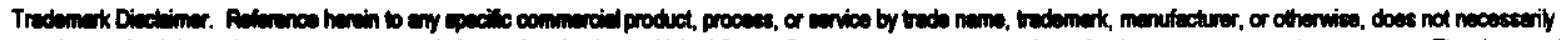

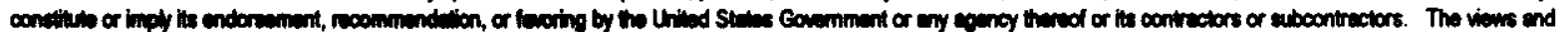

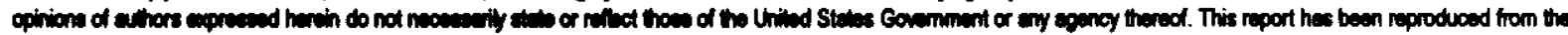

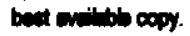

Pindind in the Unind Stime of Annite.

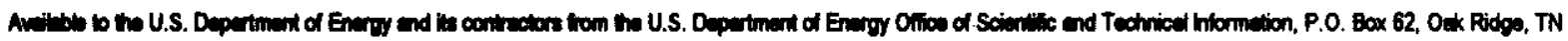
37831; Tehphon: 428576-101.

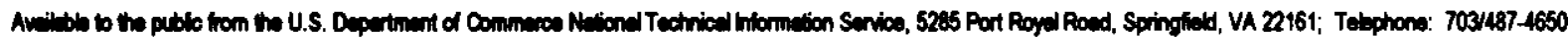




\section{INTRODUCTION}

The purpose of the Environmental Management Performance Report (EMPR) is to provide the Department of Energy Richland Operations Office's (DOE-RL's) report of Hanford's Environmental Management (EM) performance by:

- Project Hanford Management Contract (PHMC) through Fluor Hanford, Inc. (FH) and its subcontractors,

- Environmental Restoration Contract through Bechtel Hanford, Inc. (BHI), and its subcontractors,

- Pacific Northwest National Laboratories (PNNL) for Science and Technology support to the EM Mission, and

- Office of Safety Regulation of the TWRS Privatization Contractor.

This report is a monthly publication that summarizes EM Site performance under RL Operations Office. It is organized by the four sections listed above, with each section containing an Executive Summary and Area Performance Summaries.

The report date on the cover reflects the month in which the report is released. 


\section{Project Hanford Management Contractor Environmental Management Performance Report to DOE Richland Operations Office May 2000}

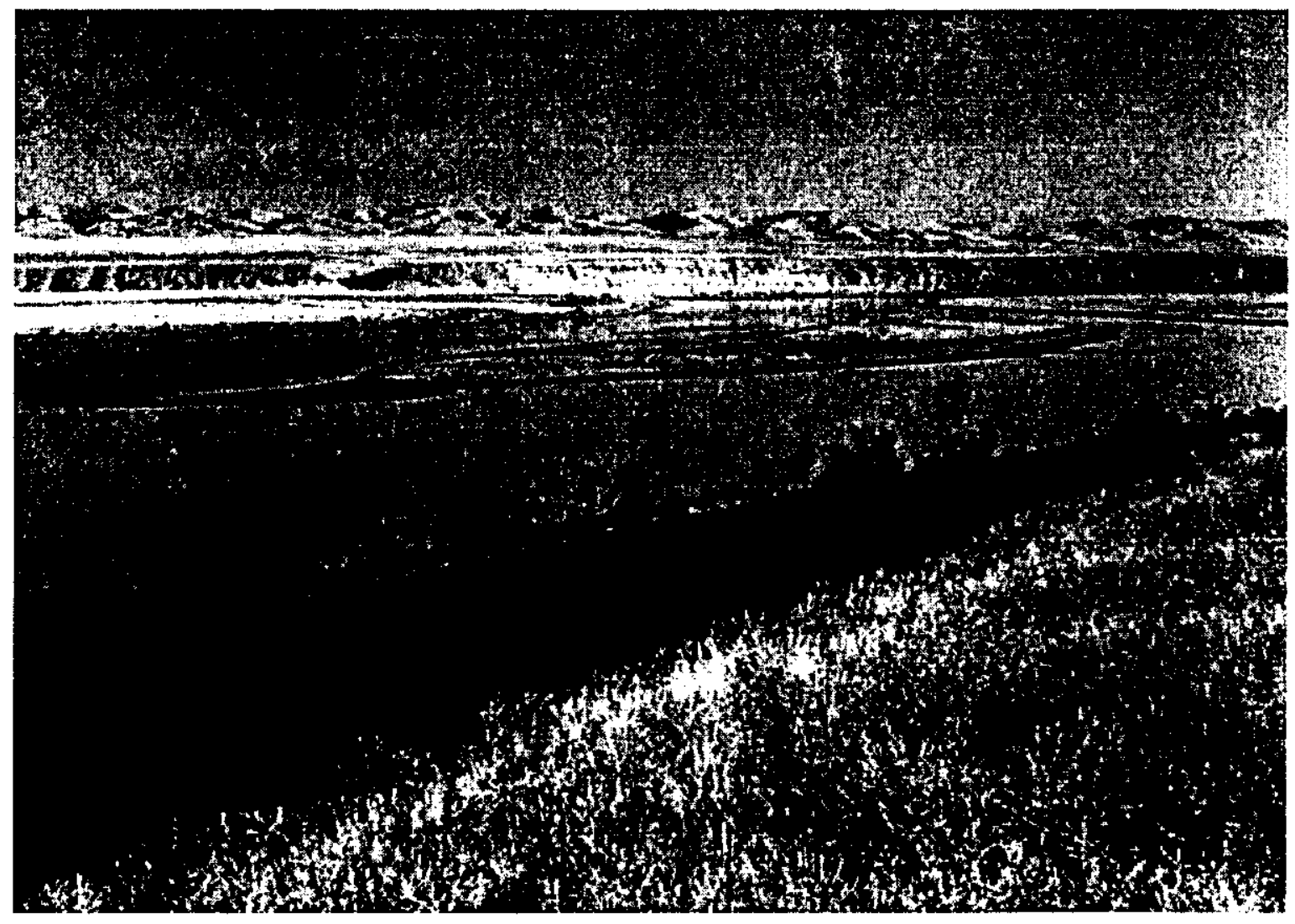

\section{Fluor Hanford}

A Fluor Global Services Company 
PHMC Environmental Management Performance Report $M a y, 00070$

\section{Table of Contents}

Section

Executive Summary

The Plateau

Waste Management....................................................... B: 1

Analytical Services (222-S, HASP, WSCF) ........................ B: 2

Nuclear Material Stabilization ......................................... C: 1

\section{The River}

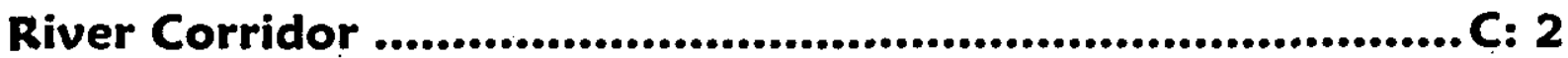

Spent Nuclear Fuel .................................................................. D

Advanced Reactors Transition ...................................................... E

EM - 50 Science \& Technology Activities.................................... F

\section{The Future}

HAMMER

\section{Multiple Outcomes}

Landlord

Support.

National Programs 


\section{INTRODUCTION}

The purpose of this report is to provide the Department of Energy Richland Operations Office 1 (DOE-RL) a report of the Project Hanford Management Contractors' (PHMC)

Environmental Management (EM) performance by Fluor Hanford (FH) and its subcontractors. This report is a monthly publication that summarizes the PHMC EM performance. In addition, it includes some PHMC-level data not detailed elsewhere in the report.

Section A, Executive Summary, provides an executive level summary of the cost, schedule, and technical performance described in this report. It summarizes performance for the period covered, highlights areas worthy of management attention, and provides a forward look to some of the upcoming key performance activities as extracted from the PHMC baseline.

The remaining sections provide detailed performance data relative to each individual Project (e.g., Waste Management, Spent Nuclear Fuels, etc.), in support of Section A of the report. A glossary of terms is provided at the end of this report for reference purposes. Unless otherwise noted, the Safety, Conduct of Operations, Metrics, and Cost/Schedule data contained herein is as of March 31, 2000. All other information is updated as noted. 


\section{INTRODUCTION}

This section provides an executive level summary of the performance information covered in this report and is intended to bring to Management's attention that information considered to be most noteworthy. All cost, schedule, milestone commitments, performance measures, and safety data is current as of March 31 . Accomplishments, Issues and Integration items are current as of April 19 unless otherwise noted.

The section begins with a description of notable accomplishments that have occurred since the last report and are considered to have made the greatest contribution toward safe, timely, and costeffective clean up. Following the accomplishment section is an overall fiscal year-to-date summary analysis addressing cost, schedule, and milestone performance. Overviews of safety ensue. The next segment of the Executive Summary, entitled Critical Issues, is designed to identify the high-level challenges to achieving cleanup progress.

The next section includes Critical Few Performance Measures and FY 2000 EM Management Commitments. The EM Management Commitments include both High Visibility Project milestones and EM Corporate Performance Measures.

The Key Integration Activities section follows next, highlighting PHMC activities that cross contractor boundaries and demonstrate the shared value of partnering with other Site entities to accomplish the work. Concluding the Executive Summary, a forward-looking synopsis of Upcoming Planned Key Events is provided.

\section{NOTABLE ACCOMPLISHMENTS}

- As of April 14, 2000, a total of 224 cans of Plutonium oxides and sludges have been stabilized through thermal stabilization (23 items since last report).

- The installation of three additional muffle furnaces for thermal stabilization of oxides was completed. A total of five furnaces are now operational.

- The first four Multi-Canister Overpacks (MCOs) were shipped from Joseph Oat, Inc. Fabrication of the MCO baskets continued at the Hanford Site.

- The SNF sludge acceleration strategy was approved by RL. This strategy will accelerate completion of sludge removal from the $\mathrm{K}$ Basins by one year, while reducing the SNF Project total life cycle cost by approximately $\$ 16$ million.

- The results of the follow up visit for certification of the Hanford Site for characterization, certification and shipment of TRU wastes to the WIPP was completed. All five Corrective Action Reports (CARs) were closed.

- Progress continues toward Accelerated Deactivation of the 327 Facility with the removal of 157 of $\sim 300$ sample cans from Dry Storage. Additionally, size reduction of Pin Tubes for packaging into shielded drums is complete.

- In a ceremony at the Volpentest HAMMER Training and Education Center, the U.S. Department of Labor, OSHA (Occupational Safety and Health Administration) and the U.S. Department of Energy formally celebrated their new partnership. The partnership will bring effective, rigorous, performance-based training programs (formerly offered only at the OSHA Training Institute in Des Plaines, Illinois) to the Tri-Cities region. 


\section{Performance Data AND ANalysis}

The following provides a brief synopsis of overall PHMC Environmental Management (EM) cost, schedule, and milestone performance.

\section{FY 2000 Cost and Schedule Performance}

Cost Performance - Fiscal-year-to-date (FYTD) cost performance reflects a four percent ( $\$ 11.0$ million) unfavorable cost variance that is within the established $+10 /-5$ percent threshold.

Schedule Performance - There is a FYTD eight percent ( $\$ 23.9$ million) unfavorable schedule variance.

Data Through March 2000

\begin{tabular}{|c|c|c|c|c|c|c|c|}
\hline & & \multirow{3}{*}{ PEM } & \multicolumn{5}{|c|}{ Current Fiscal Year Performance (S $\times$ Million) } \\
\hline & & & \multicolumn{3}{|c|}{ FYTD } & \multirow{2}{*}{$\begin{array}{l}\text { Schedule } \\
\text { Variance }\end{array}$} & \multirow{2}{*}{$\begin{array}{c}\text { Cost } \\
\text { Variance }\end{array}$} \\
\hline & & & BCWS & BCWP & ACWP & & \\
\hline 1.2 & $\begin{array}{l}\text { Waste Management } \\
\text { TP02,WM03-05 }\end{array}$ & 110.1 & 51.4 & 48.6 & 48.6 & (2.8) & 0.0 \\
\hline 1.2 .4 & $\begin{array}{l}\text { Analytical Sves (222-S,HASP,WSCF) } \\
\text { wM06 }\end{array}$ & 27.8 & 13.7 & 13.4 & 14.2 & $(0.3)$ & $(0.8)$ \\
\hline 3.3 & $\begin{array}{l}\text { Spent Nuclear Fuel } \\
\text { WM0I }\end{array}$ & 195.1 & 91.4 & 89.4 & 104.9 & (2.0) & $(15.5)$ \\
\hline 1.4 .5 & $\begin{array}{l}\text { Nuclear Materials Stabilization } \\
\text { TP0S }\end{array}$ & 127.2 & 65.7 & 54.0 & 54.5 & (11.8) & (0.5) \\
\hline 1.4 & $\begin{array}{l}\text { River Corridor } \\
\text { TP01,TP04,TP08,TP10,TP12,TP14 }\end{array}$ & 59.9 & 27.0 & 26.3 & 26.0 & $(0.7)$ & 0.3 \\
\hline 1.5 & $\begin{array}{l}\text { Landiord } \\
\text { TP13 }\end{array}$ & 14.3 & 6.3 & 5.1 & 3.0 & (1.2) & 2.1 \\
\hline 1.8 & $\begin{array}{l}\text { Mission Support } \\
\text { OT01, От04 }\end{array}$ & 46.9 & 23.5 & 20.3 & 18.0 & (3.2) & 2.3 \\
\hline 1.9 & $\underset{\text { HMO1 }}{\text { HAMMER }}$ & 6.2 & 3.0 & 3.0 & 2.7 & 0.0 & 0.4 \\
\hline \multirow[t]{2}{*}{1.12} & Advanced Reactors (EM) & 1.5 & 0.6 & 0.6 & 0.6 & 0.0 & 0.0 \\
\hline & PHMC EM Clean-Up Projects & 589.0 & 282.6 & 260.7 & 272.4 & (21.9) & $(11.7)$ \\
\hline \multirow[t]{4}{*}{1.11} & $\begin{array}{l}\text { National Programs } \\
\text { OT02, wM07 }\end{array}$ & 5.8 & 2.0 & 1.8 & 1.8 & $(0.2)$ & 0.0 \\
\hline & $\begin{array}{l}\text { Technology Development } \\
\text { (EM-s0) }\end{array}$ & 22.1 & 10.2 & 8.4 & 7.8 & (1.8) & 0.6 \\
\hline & Total Other Projects & 27.9 & 12.2 & 10.2 & 9.6 & $(2.0)$ & 0.6 \\
\hline & Total PHMC Projects & 616.8 & 294.8 & 271.0 & 282.0 & (23.9) & (11.0) \\
\hline
\end{tabular}

Notes: Column headings (BCWS, BCWP, etc.) are defined in the glossary at the end of the report. Calculations are based on Project Baseline Summary detail. Waste Management and Nuclear Materials Stabilization have included RL-Directed costs (e.g. steam and laundry) in the PEM BCWS. Advanced Reactors (EM) have included steam. Technology Development does not include ORP/RPP TTPs currently reported in the RL Dataset in the HQ-IPABSPEM.

The following Cost/Schedule and Variance to Plan chart provides an overall graphical view of fiscal year to date performance and cost and schedule performance indicators. 
fy 2000 Cost / Schedule Performance March 2000 Cumulative to Date Status

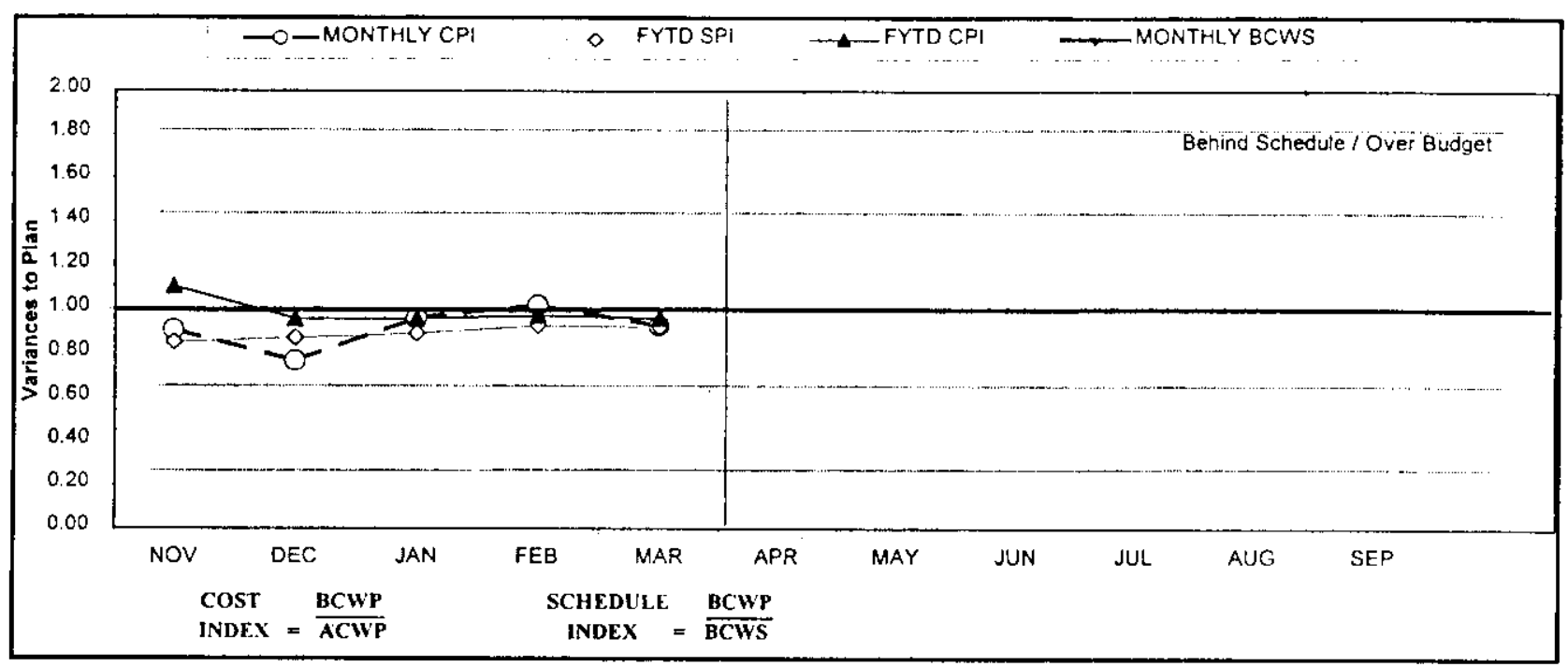

\begin{tabular}{|c|c|c|c|c|c|c|c|c|c|c|c|c|}
\hline FY 2000 & OCT & NOV & DEC & JAN & FEB & MAR & APR & MAY & JUN" & JUL & AUG & SEP \\
\hline MONTHLY SPI & 091 & 0.82 & $\overline{0.91}$ & 0.94 & 1.06 & 7 & & & & & & \\
\hline MONTHILYCPI & 1.63 & 0.91 & 0.77 & 0.96 & $\overline{1.02}$ & $6 \cdot 2$ & & & & & & \\
\hline FYTD SP1 & 0.91 & 0.85 & 087 & 0.89 & $\overline{0.93}$ & 092 & & & & & & \\
\hline FYTDCPI & 1.63 & 1.10 & 0.96 & 096 & 097 & 096 & & & & & & \\
\hline MONTHLY BCWS & 5 & $\begin{array}{l}533,767 \\
\end{array}$ & 43,044 & 45,672 & 48,699 & $\begin{array}{lll}5 & 71,043\end{array}$ & 48,523 & 59.465 & 45,872 & (5 $\quad 47,144$ & 59,103 & 581,879 \\
\hline MONTHLYBCWP & 529.522 & \$ 44,109 & 39.143 & 42,999 & $5 \longdiv { , 4 6 8 }$ & 63.739 & & & & & & \\
\hline MONTHLY ACWP & 518,079 & \begin{tabular}{|ll}
5 & 48,593
\end{tabular} & 30,990 & 44,809 & 50.494 & 69,041 & & & & & & \\
\hline FYTD BCWS & \$ 32,593 & 586,360 & \begin{tabular}{|l|l}
5 & 129,403
\end{tabular} & \begin{tabular}{|l|l|}
5 & 175,075 \\
\end{tabular} & 5223,774 & $\begin{array}{ll}5 & 294,817\end{array}$ & $\$ 343,340$ & 5402,805 & 5448,677 & 5495,821 & $\$ 554.924$ & S 616,803 \\
\hline FYTD BCWP & $\$ 29,522$ & \begin{tabular}{|l|} 
S 73,631 \\
\end{tabular} & $\begin{array}{ll}5 & 112,774\end{array}$ & $\begin{array}{ll} & 155,753 \\
\end{array}$ & $\begin{array}{ll}5 & 207.221\end{array}$ & $\$ 270,960$ & & & & & & \\
\hline FYTD ACWP & 5 18,079 & S 66,672 & \$ 1117,662 & \begin{tabular}{|ll}
5 & 162,471 \\
\end{tabular} & \begin{tabular}{|l|l|} 
S & 212.965 \\
\end{tabular} & 5282,006 & & & & & & \\
\hline
\end{tabular}

\section{Milestone Performance}

Milestones represent significant events in project execution. They are established to provide a higher level of visibility to critical deliverables and to provide specific status about the accomplishment of these key events. Because of the relative importance of milestones, the ability to track and assess milestone performance provides an effective tool for managing the PHMC EM cleanup mission.

FYTD milestone performance (Enforceable Agreement [EA], U.S. Department of Energy-Headquarters [DOE-HQ], and RL) shows that 26 of 36 (72 percent) approved baseline milestones were completed on or ahead of schedule, 2 milestones ( 6 percent) were completed late, and 8 milestones ( 22 percent) are overdue. The eight overdue milestones are associated with six projects: Nuclear Material Stabilization-two, River Corridor-one, Spent Nuclear Fuel —one, Environmental Management (EM)-50 - two, Landlord—one, and Mission Support-one. These overdue milestones do not share a common cause.

In addition to the FY2000 milestones described above, there are three overduc milestones from the prior fiscal year (FY1999). Further details regarding these milestones may be found in the Project Sections.

FY 2000 information is depicted graphically below and on the following page. For additional details related to the data in the graphs and prior year milestones, refer to the relevant project section titled "Milestone Exception Report." 
FY 2000 information reflects the current approved baseline. Changes in both the number and type of milestones from month to month are the result of Baseline Change Requests (BCRs) approved during the year.

\begin{tabular}{|c|c|c|c|c|c|c|c|c|}
\hline \multirow[b]{2}{*}{ MILESTONE TYPE } & \multicolumn{4}{|c|}{ FISCAL YEAR-TO-DATE } & \multicolumn{3}{|c|}{ REMAINING SCHEDULED } & \multirow[b]{2}{*}{$\begin{array}{c}\text { TOTAL } \\
\text { FY } \\
2000\end{array}$} \\
\hline & $\begin{array}{c}\text { Completed } \\
\text { Early }\end{array}$ & $\begin{array}{c}\text { Completed } \\
\text { On } \\
\text { Schedule }\end{array}$ & $\begin{array}{c}\text { Completed } \\
\text { Late }\end{array}$ & Overdue & $\begin{array}{c}\text { Forecast } \\
\text { Early }\end{array}$ & $\begin{array}{c}\text { Forecast On } \\
\text { Schedule }\end{array}$ & $\begin{array}{c}\text { Forecast } \\
\text { Late }\end{array}$ & \\
\hline Enforceable Agreement & 14 & 2 & 0 & 1 & 0 & $\sqrt{6}$ & 0 & 33 \\
\hline DOE-HQ & 0 & 0 & 0 & 1 & 0 & 3 & 0 & 4 \\
\hline $\mathrm{RL}$ & 6 & 4 & 2 & 6 & 0 & 57 & 0 & 75 \\
\hline Total Project & 20 & 6 & 2 & 8 & 0 & 76 & 0 & 112 \\
\hline
\end{tabular}

\section{Total Project}

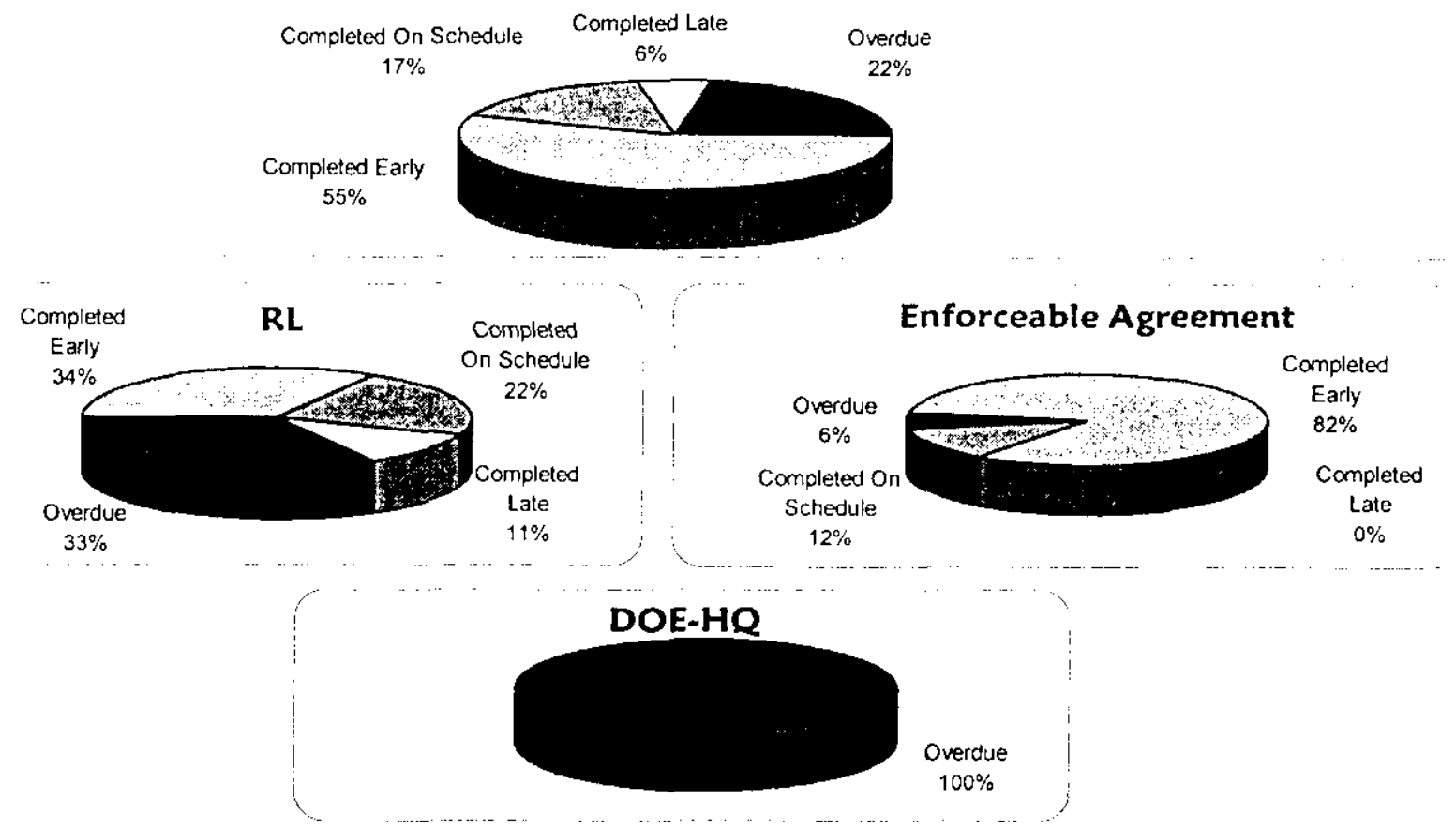




\section{MILESTONE EXCEPTIONS}

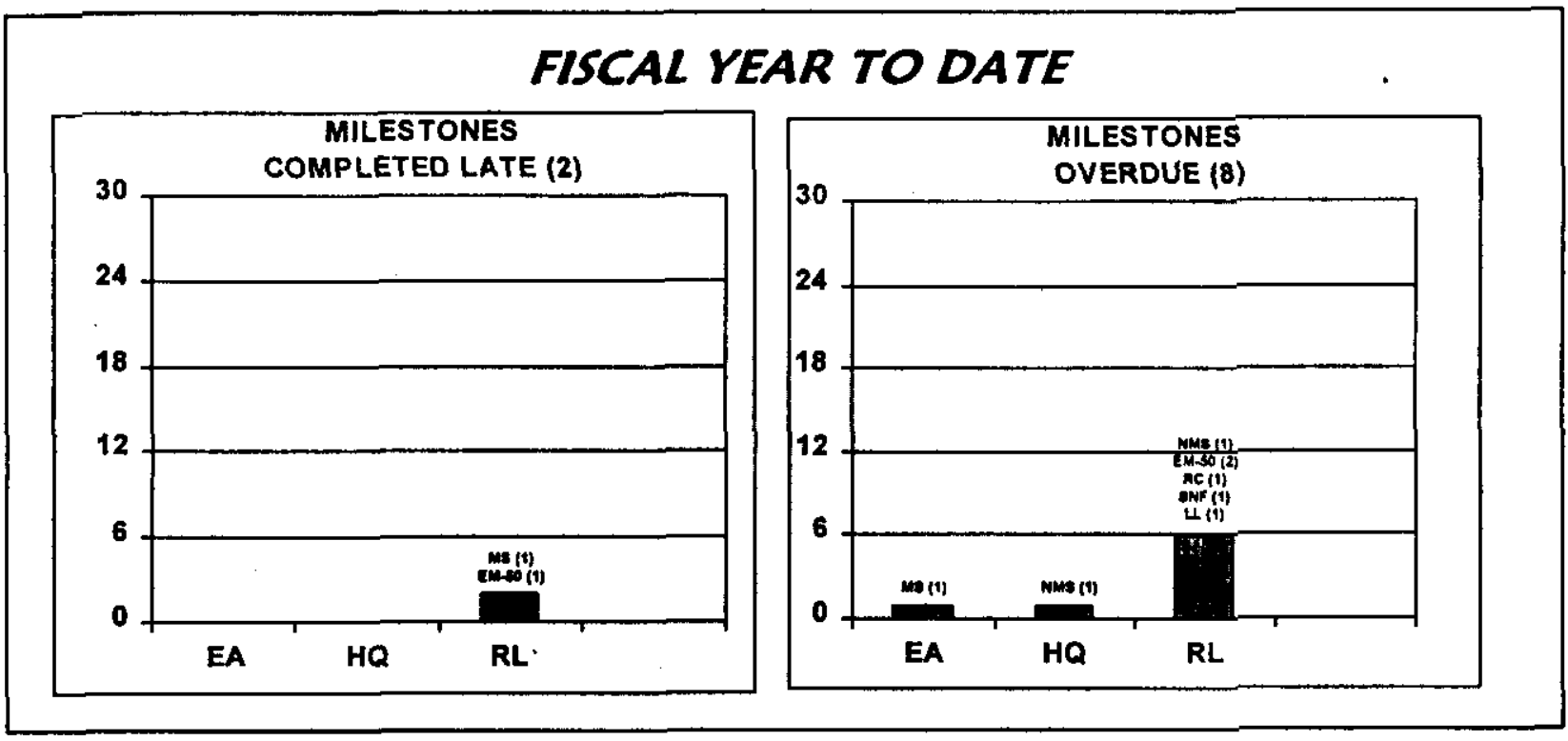

\section{REMAINING SCHEDULED}

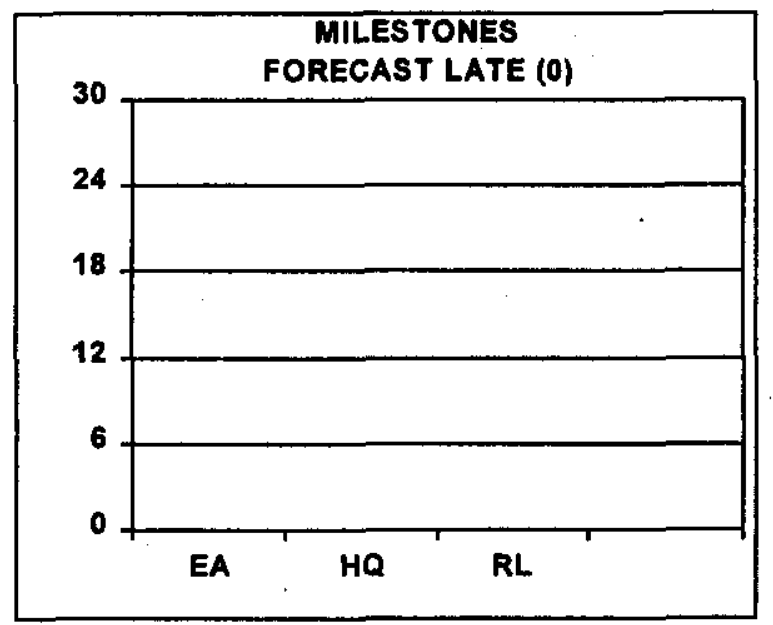

These charts provide detail by project and milestone level / type for milestones

- Completed Late

- Overdue

- Forecast Late

- Detailed information can be found in the individual project sections 


\title{
SAFETY OVERVIEW
}

The focus of this section is to document trends in occurrences. Improvements in these rates are due to the efforts of the PHMC workforce as they implement the Integrated ES\&H

Management System (ISMS), work towards achieving Voluntary Protection Program (VPP) "star" status, and accomplish work through Enhanced Work Planning (EWP). Safety and health statistical data is presented in this section.

\section{Significant Safety and Health EVENTS}

Rates have been stable for over two years. This safety performance plateau has been recognized by the safety organizations, and Fluor Hanford kicked off its Integrated Safety Approach initiative on December 6, 1999 in order to take safety performance to a new level. This initiative focuses on the "people side" of accident prevention.

\section{Total OSHA Recordable Case Rate}

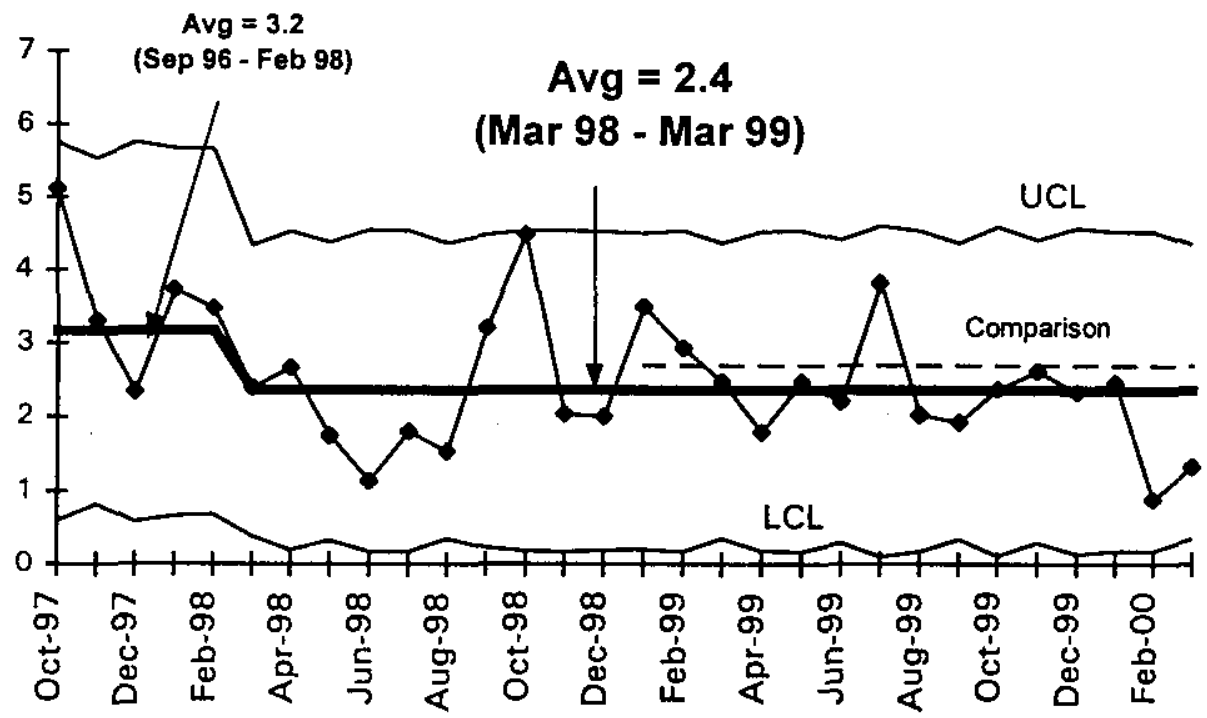

\author{
PHMC \\ FY $1999=2.6$ \\ FY $2000=2.0$ \\ Contractor Comparison \\ Average $=32.7($ CY99) \\ This indicator had a \\ nearly significant \\ decrease in February \\ and March. \\ Consolidation of the \\ projects under Fluor \\ Hanford, and actions \\ taken at the end of FY \\ 1999 to look at injury \\ sources appears to be \\ having an effect.
}




\section{OSHA LOST/RESTRICTED WORKDAY CASE RATE}

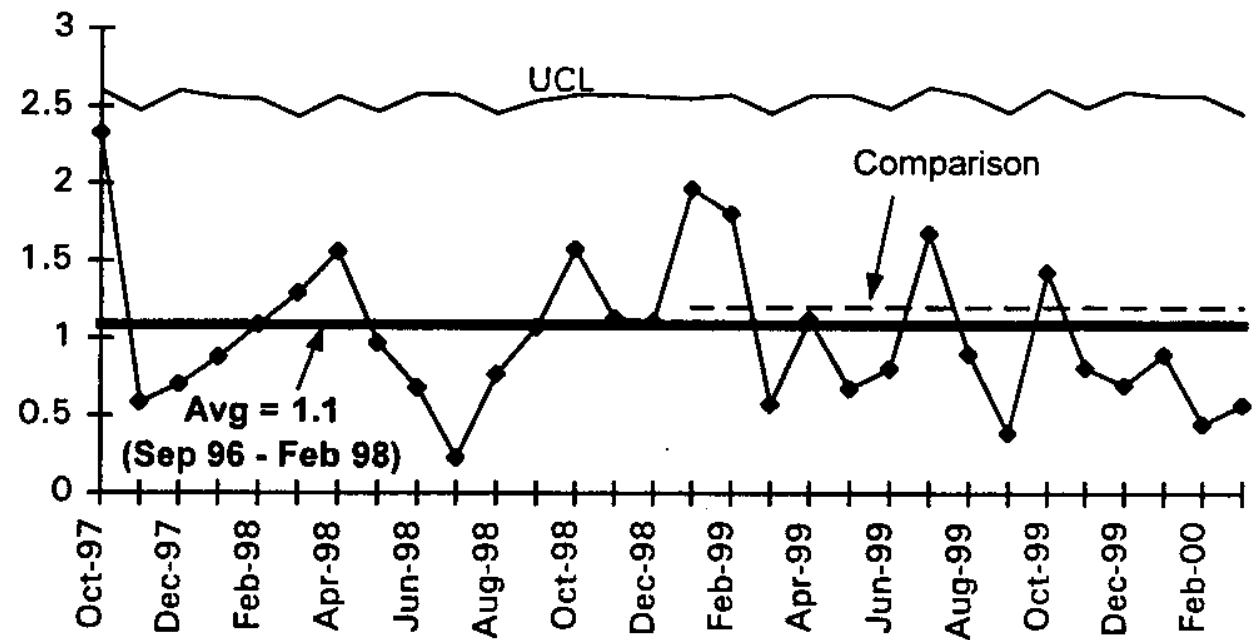

PHMC

FY $1999=1.1$

FY 2000 to date $=0.8$

Contractor Comparison

Average $=1.2($ CY99)

The data have been stable for the past two years. Most of the recent months (over the past year) have been well below average, an indicator of potential improvement.

\section{First Aid Case Rate}

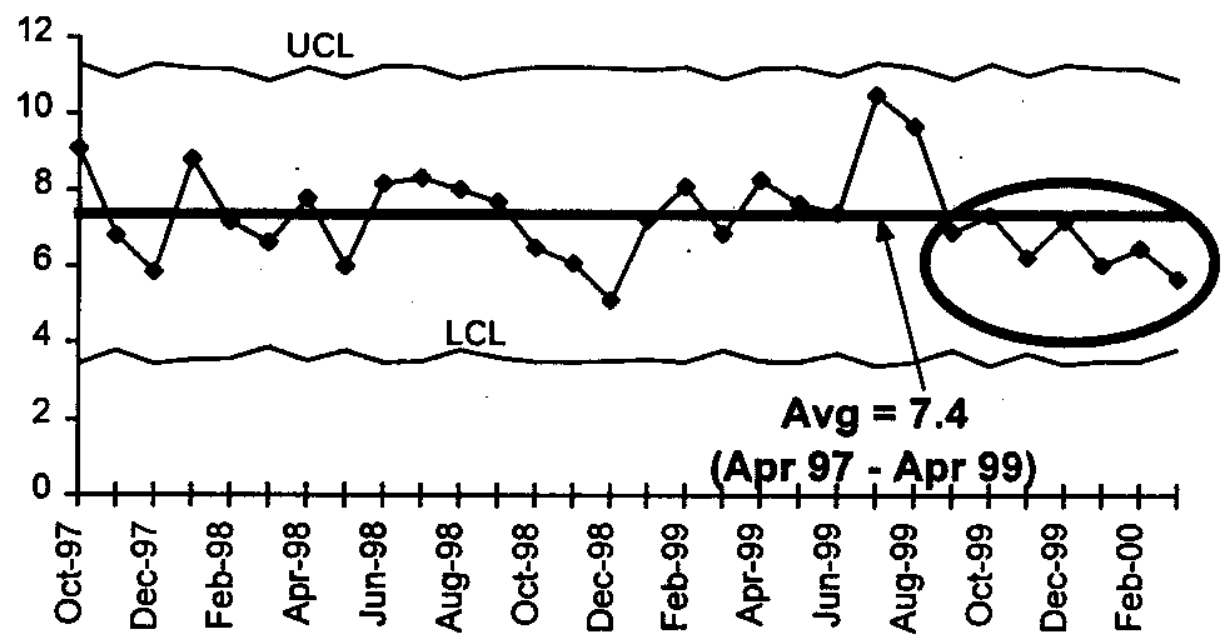

\section{PHMC}

First Aid Rate undergoes seasonal cycles. Increases occur in warmer weather due to insect and animal encounters, and due to wind related minor injuries. First Aid case rate has remained relatively stable, a good indicator that injuries are not being underreported. There are currently 7 months in a row below average. 


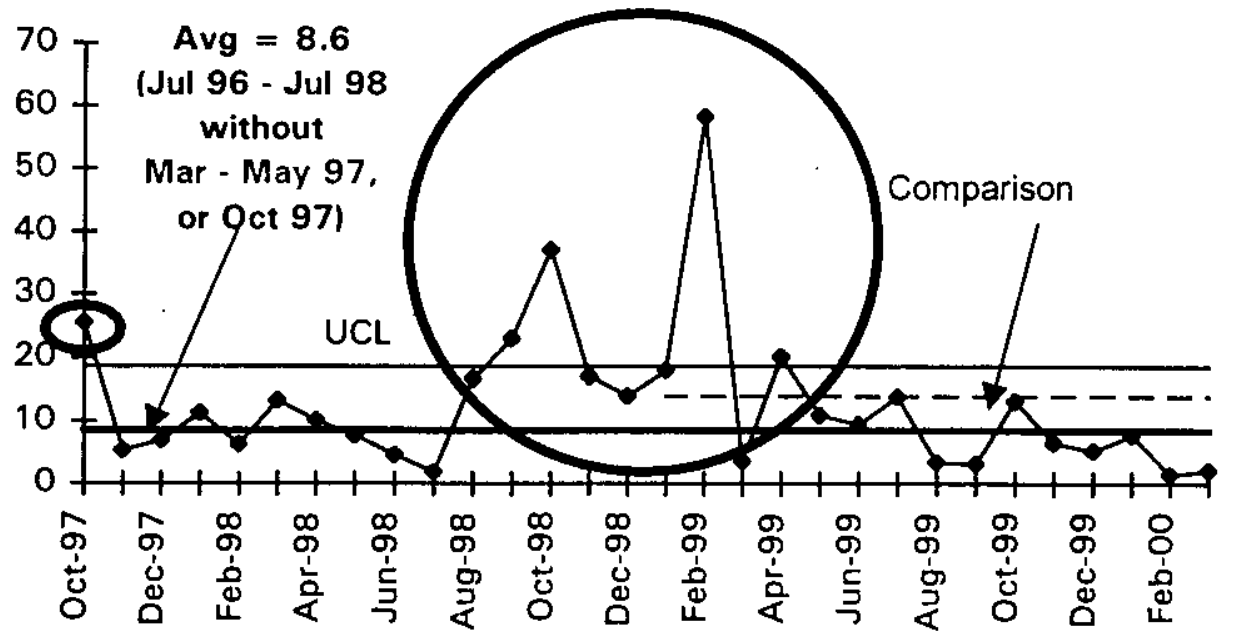

PHMC

FY $1999=17$

FY 2000 to date $=5.9$ Contractor Comparison Average $=13.9$ (CY99) There has been a long term cycle over the past three years of decreases for 7 to 9 months, followed by increases. Additional days gained on cases in FY 1999 have negated the previously noted significant decrease.

\section{Critical Technical Issues}

\section{- 324 FACILITY BEHIND SCHEDULE}

The 324 Building Fire Hazards Analysis (FHA) revision supporting the 324 Building Safety Analysis Report (SAR) update resulted in revised combustible load limits. An implementation plan has been submitted for approval that allows either 1) work to continue while maintaining revised combustible load limits or 2) implements compensatory measures, such as establishing a fire watch, eliminating ignition sources, and shutting off lights when not needed. This change will not cause a schedule impact, but it may create a cost impact to work in progress.

\section{- CRACK DISCOVERED ON B PLANT W-059 DUCT REPLACEMENT}

Good progress was made toward closeout of the actions required by the B Plant transfer Memorandum of Agreement (MOA). Vibration testing of the ducting was completed. Subject matter experts verified that the crack was caused by vibration from harmonics that occurred when the system was operated at a low-flow condition. The system will be run at full-flow to avoid the problem once the field repair/plate welding is complete. The Department of Health has extended the due date to June 30,2000 for restart of the exhaust system. 
em Corporate Performance Measures

\begin{tabular}{|c|c|c|c|c|}
\hline Performance Measures & $\begin{array}{l}\text { EMManagement } \\
\text { Commitment }\end{array}$ & $\begin{array}{c}\text { FY } 2000 \text { Current } \\
\text { Baseline }\end{array}$ & $\begin{array}{l}\text { FYTD } \\
\text { Planned }\end{array}$ & $\begin{array}{l}\text { FYTD } \\
\text { Actual }\end{array}$ \\
\hline \multicolumn{5}{|l|}{ Facilities Deactivated/Decommissioned } \\
\hline Facifities deactivated & $2 \pi$ & $2 \pi$ & .12 & 20 \\
\hline Facilities decommissioned & T4 & 13 & 5 & 5 \\
\hline \multicolumn{5}{|l|}{ TRansUranic (TRU) Waste } \\
\hline Stored - total inventory $\left(\mathrm{m}^{3}\right)$ & 16,333 & 16,316 & 16,333 & 16,324 \\
\hline Disposed (shipped to DOE site $\mathrm{m}^{3}$ ) & 55 & 55 & 0 & 0 \\
\hline \multicolumn{5}{|l|}{ High Level Waste } \\
\hline Treated $\left(\mathrm{m}^{3}\right)$ & 3,600 & 3,600 & 0 & 0 \\
\hline \multicolumn{5}{|l|}{ Mixed Low LeveI Waste } \\
\hline Stored - total inventory $\left(\mathrm{m}^{3}\right)$ & 7,852 & 7,852 & 8,862 & 9,112 \\
\hline Treated $\left(\mathrm{m}^{3}\right)$ & 1,060 & 1,060 & 560 & 98 \\
\hline Disposed & 835 & 835 & 479 & 248 \\
\hline \multicolumn{5}{|l|}{ Low LeveTWaste } \\
\hline Stored - total inventory $\left(\mathrm{m}^{3}\right)$ & 180 & 180 & 180 & 180 \\
\hline Disposed (on-site/commercial) $\left(m^{3}\right)$ & 6,936 & 6,936 & 3,328 & 3,018 \\
\hline \multicolumn{5}{|l|}{ Material Stabilized } \\
\hline Plutonium Oxide (containers) & 400 & 140 & 47 & 164 \\
\hline Plutonium Solution (L) & 255 & 255 & 0 & 13 \\
\hline Plutonium Residue $(\mathrm{kg})$ & 29 & 29 & 0 & 0 \\
\hline Technology Deployments & 9 & 7 & 2 & \\
\hline \multicolumn{5}{|l|}{ Pollution Prevention } \\
\hline HAZ (MT) & 470 & 470 & 104 & T04 \\
\hline SAN(MT) & 138 & T38 & 60 & 60 \\
\hline $\mathrm{LLW}(\mathrm{m} 3)$ & 45 & 45 & TI & $\pi$ \\
\hline MLLW $(\mathrm{m} 3)$ & T,781 & 1,781 & 322 & 322 \\
\hline \multicolumn{5}{|l|}{ Cleanup/Stabilized Waste Avoided } \\
\hline FY 2000 planned baseline amount $\left(\mathrm{m}^{3}\right)$ & 19,160 & 19,160 & 2,997 & 2,997 \\
\hline FY 2001 planned baseline amount $\left(\mathrm{m}^{3}\right)$ & 19,257 & 19,257 & N/A & N/A \\
\hline
\end{tabular}

All of the above reflect the status as of March 31 . For deviations $+/-10 \%$, see the following projects sections: Facilities Deactivated (Landlord); MLLW Treated, MLLW Disposed (Waste Management Project); Materials Stabilized, Plutonium Oxide and Solution (Nuclear Materials Stabilization Project). Technology Deployment Management Committments are shared with ERC. 
Management Commitment Milestones as of March 31, 2000

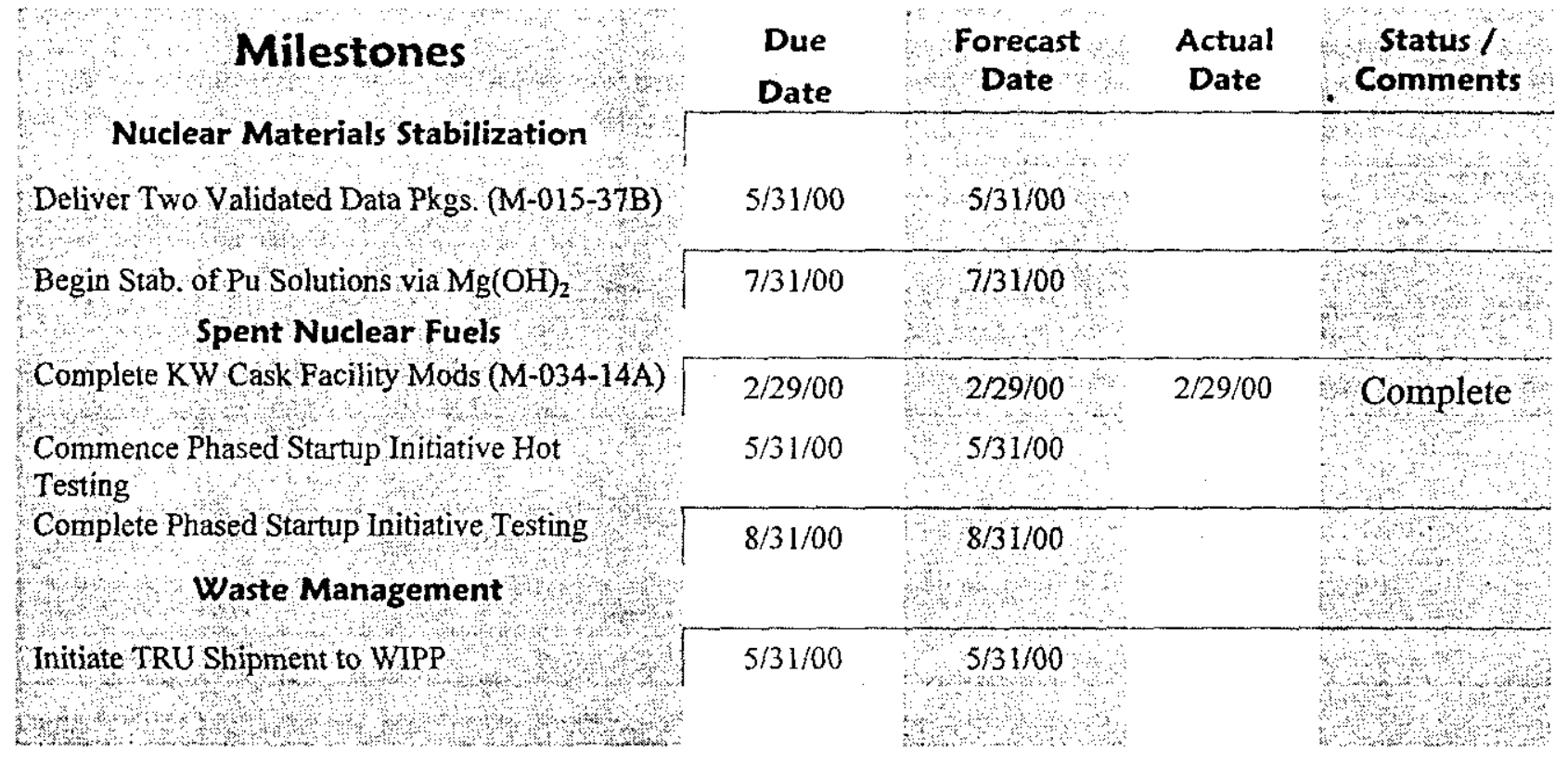

\section{Critical Few Performance Measures}

\section{Performance Measure} Spent Nuclear Fuel:

Measure - Amount of fuel removed

Declaration of Readiness to move Spent Nuclear Fuel

Phased Startup Initiative Phases I \& II

K-East Fuel Retrieval System facility modifications to allow FRS installation

Measure - Amount of SNF Stabilized

\section{$324 / 327$ Building Deactivation}

Measure - Number of buildings dispositioned

\section{Waste Management:}

Measure - Adequacy of waste management services support

Number of analytical equivalent units (AEU's) analyzed

Through-put efficiency of effluent treatment facility (ETF) gpm

Number of 242-A evaporator campaigns completed

Measure - Retrieve and ship TRU offsite

Number of drums retrieved

Number of shipments to WIPP

Measure - MLLW Treated (m3)

Measure - MLLW Disposed (m3)

\section{Plutonium Stabilization:}

Measure - Pu metal/oxides/other types dispositioned (items)

Status as of March 31, 2000

\section{Green}

Red

NA (contract mod issued to delete)

NA FY 2000

\section{Green}

\section{Green \\ Green \\ Green \\ Green \\ Green \\ Green \\ Green}

Yellow

Yellows noted above are behind schedule but recoverable, action plans in place. Red is either missed or unrecoverable. Details can be found in the Project Sections. 


\section{KEY INTEGRATION ACTIVITIES}

The following are the key technical integration activities that are currently underway and cross 1 project/contractor lines. These activities are being addressed by inter-discipline and interproject groups and demonstrate that Hanford Site contractors are working together to accomplish the EM Clean up mission.

- Spent nuclear fuel (SNF) final disposition interface activities, including OCRWM QA Program implementation, ongoing with National SNF Program.

- SNF Project fuel removal acceptance criteria and conceptual design reviews for 324 Building (B Cell) ongoing with River Corridor Project.

- K Basins sludge removal and Shippingport (PA) Pressurized Water Reactor Core 2 SNF removal implementation activities ongoing with Waste Management.

- WM working with DOE-RL, DOE-HQ and other Sites to develop and define Hanford's role in disposing of waste from other sites. Hanford's role as one of the identified LLW/MLLW disposal sites for the Complex is yet to be fully defined.

- WM supporting the RL declaration of Readiness-to-Proceed in support of the Office of River Protection (ORP) Privatization contract.

- WM working with PNNL, EM-50 and Mixed Waste Focus Area (MWFA) to obtain funding in support of mixed waste processing.

- Nuclear Material Stabilization Project continues working with PNNL on activities associated with the $\mathrm{Mg}(\mathrm{OH})_{2}$ process in order to accelerate the plutonium solution stabilization process, and polycube stabilization issues (gathering data for the SAR).

- Analytical Services continues to support BNFL efforts to establish required analytical support for glassification operations.

- In the longer term, BNFL could utilize unused space at WSCF for cold run test support and process laboratory analytical equipment testing.

- The 222-S laboratory, with some refurbishment might become a low cost option to a new large-scale laboratory associated with the glassification facility.

- Landlord is establishing a Hanford Site Planning Advisory Board made up of cooperating agencies and Tribal representatives. 


\section{Upcoming Planned Key Events}

The following Key events are extracted from the authorized baseline and are currently expected to be accomplished during the next eight months. Most are Enforceable Agreement (EA), HQ or DNFSB Milestones.

\section{Waste Management:}

- Complete the 242-A Evaporator Campaign in May 2000 in support of the River Protection Project.

- Treat 1,160 cubic meters (includes 100 cubic meters stretch) of MLLW at ATG by August 2000; dispose of Land Disposal Restriction compliant waste by September 2000.

- Retrieve 425 drums of suspect TRU waste from the Low-Level Burial Grounds by September 2000.

- Accelerate Readiness to Receive Spent Nuclear Fuel K Basin Sludge.

- Clear three sections of the T Plant Canyon deck in FY 2000.

- Complete entire deck clearing by FY 2001.

\section{Spent Nuclear Fuels:}

- Complete integrated subsystem testing of the Cold Vacuum Drying facility by the end of May.

- Deliver first shipment of Multi-Canister Overpack (MCO) baskets by June 1, 2000.

- Complete Cask Loadout System (CLS) startup testing by mid-June 2000.

- Begin DOE Operational Readiness Review (ORR) for fuel removal by mid-September 2000.

- Begin K West Basin fuel removal, drying \& storage operations by November 30, 2000.

\section{River Corridor Project:}

- Complete all B Plant closeout activities by June 2000.

- Complete ISMS verification of Phase I \& II readiness activities by June 2000.

- Issue the final report for the 300 Area Waste Acid Treatment System (WATS) Resource Conservation and Recovery Act (RCRA) Closure Activities by September 2000.

- Complete Removal of 324 Building Radiochemical Engineering Cell (REC) B Cell Mixed Waste (MW) and Equipment by November 2000.

\section{Nuclear Materials Stabilization:}

- Begin Pu solution stabilization via $\mathrm{Mg}(\mathrm{OH})_{2}$ in the 4th quarter of FY 2000.

- Deliver glove boxes and equipment for installation in April 2000.

- Complete ORR and training activities.

- Startup Cementation operations in the 4th quarter of FY 2000.

- Begin metal stabilization processing in November 2000.

\section{Landlord}

- Complete Definitive Design for Project L-309, "Replace Portion of Main Water Lines," which replaces approximately 1,500 feet of the sanitary water lines in 200 East Area by April 28, 2000.

- Complete Definitive Design for Project L-310, "Distribution Water Line" which replaces a 2.5mile section of the 24" export water line in the 200 West Area by May 26, 2000. 
Transitioning the central plateau for long-term waste management is a key part of the Hanford 1 vision. Determining the disposition of the "canyon". facilities, deactivating the Plutonium Finishing Plant and disposing of solid waste are the desired outcomes. Projects included in The Plateau are Waste Management, Analytical Services, and Nuclear Material Stabilization. 

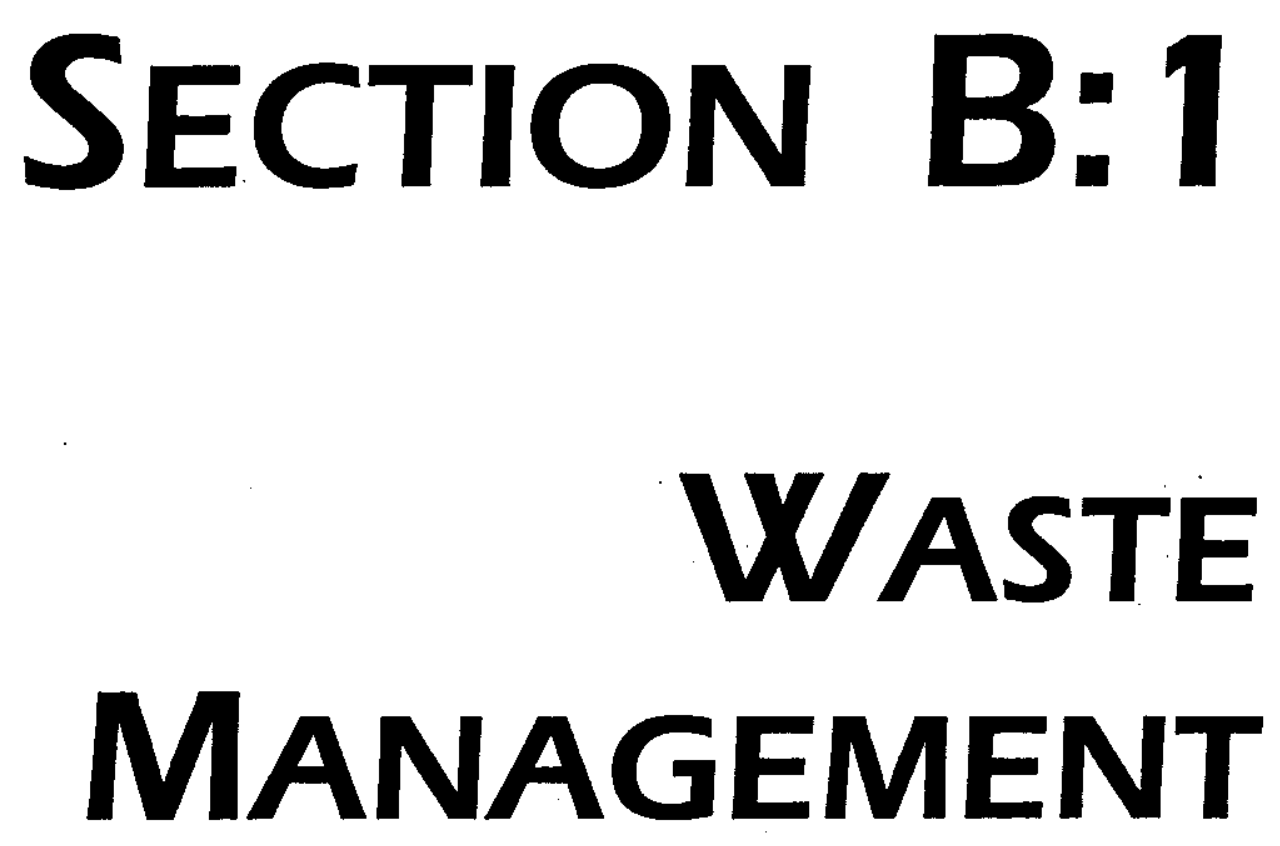

PROJECT MANAGERS

\author{
H. E. Bilson, RL
Phone: (509) $376-6628$ \\ H. E. Bilson, RL
Phone: (509) $376-6628$
}

E. S. Aromi Jr., WMH

Phone: (509) 372-1033 


\section{SUMMARY}

Waste Management consists of the Solid Waste Storage and Disposal, Project Baseline Summary (PBS) WM03, Work Breakdown Structure (WBS) 1.2.1; Solid Waste Treatment, PBS WM04, WBS 1.2.2; Liquid Effluents - 200 Area, PBS WM05, WBS 1.2.3.1; and the Waste Encapsulation and Storage Facility, PBS TP02, WBS 1.4.2.

PBS WM05 is divided between WBS 1.2.3.1, Liquid Effluents (200 LEF) and WBS 1.2.3.2, 310 TEDF/340 Facility ( 300 LEF). The 310 TEDF/340 Facility work scope is now included in the River Corridor Project, whereas the Liquid Effluents (200 LEF) work scope has remained in Waste Management. For the purpose of performance analysis, PBS WM05 is reported in its entirety in the Waste Management Project, which has the majority of the work scope and funding.

NOTE: Unless otherwise noted, the Safety, Conduct of Operations, Milestone Achievement, and Cost/Schedule Date contained herein is as of March 31, 2000. Other information is updated as noted.

The follow up visit for certification of the Hanford Site for characterization, certification and shipment of TransUranic (TRU) wastes to the Waste Isolation Pilot Plant (WIPP) was completed. All five Corrective Action Reports (CARs) have been closed and are in preparation for final signature and transmittal to the Carlsbad Area Office (CAO). The Lead Auditor will submit a letter to $\mathrm{CAO}$ recommending the Hanford Site be certified for all retrievably stored debris wastes. CAO intends to submit the final Hanford audit report to the New Mexico Environment Department (NMED) on April 28, 2000. Shipment of transuranic waste to WIPP will be scheduled as soon as practicable following NMED/CAO notification.

Fiscal-year-to-date milestone performance (EA, DOE-HQ and RL) shows that one of one milestones (100 percent) were completed on or ahead of schedule. Overall Project performance continues to be excellent. Cost and schedule goals are on track to be met.

\section{ACCOMPLISHMENTS}

- Disposed of $106,600 \mathrm{ft}^{3}\left(3000 \mathrm{~m}^{3}\right)$ (FYTD) of Low Level Waste (LLW) in the burial grounds, as planned.

- Initiated the 242A Evaporator campaign in support of RPP.

\section{SAFETY}

The project's safety rates are stable. The October 1999 Lost Away Case was a severe Acid Burn injury. However, this has been the only lost away workday case in 17 months. The project has exceeded the 668,000 safe hours. 

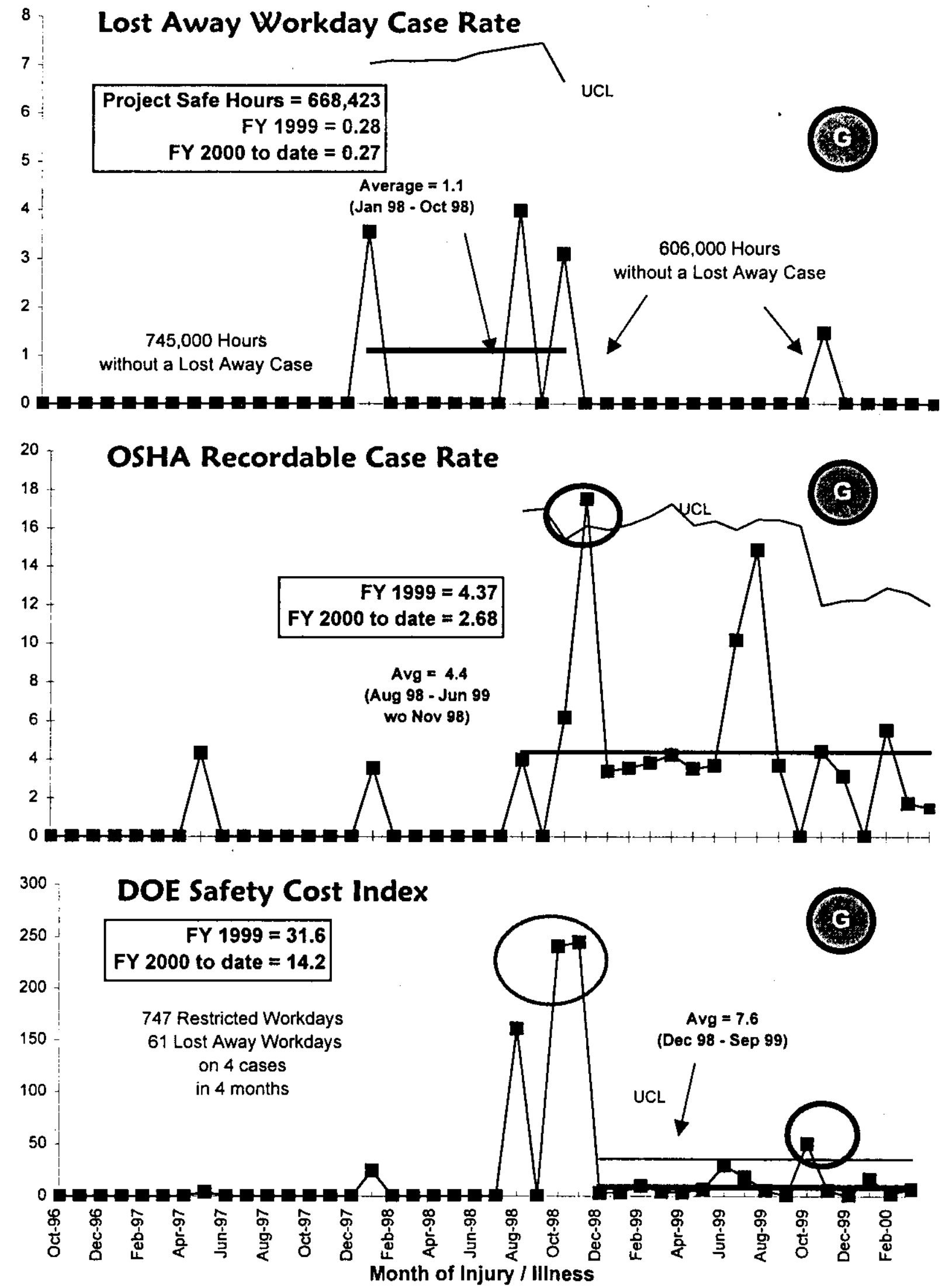


\section{CONDUCT OF OPERATIONS / ISMS STATUS CONDUCT OF OPERATIONS}

EVENTS PER 200,000 HOURS

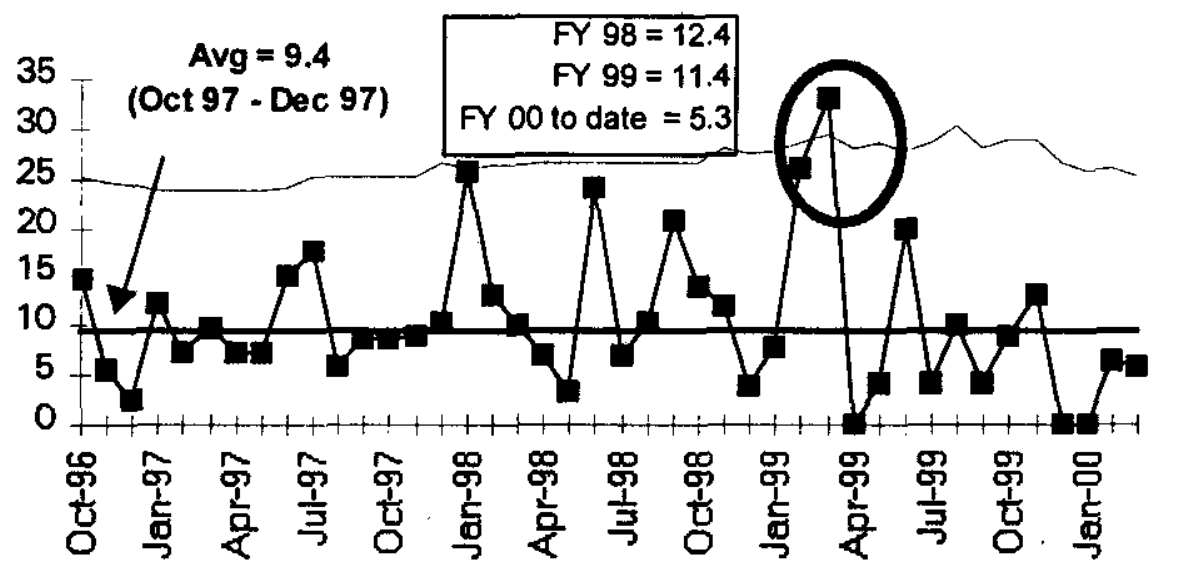

ISMS STATUS

\section{Completed activities:}

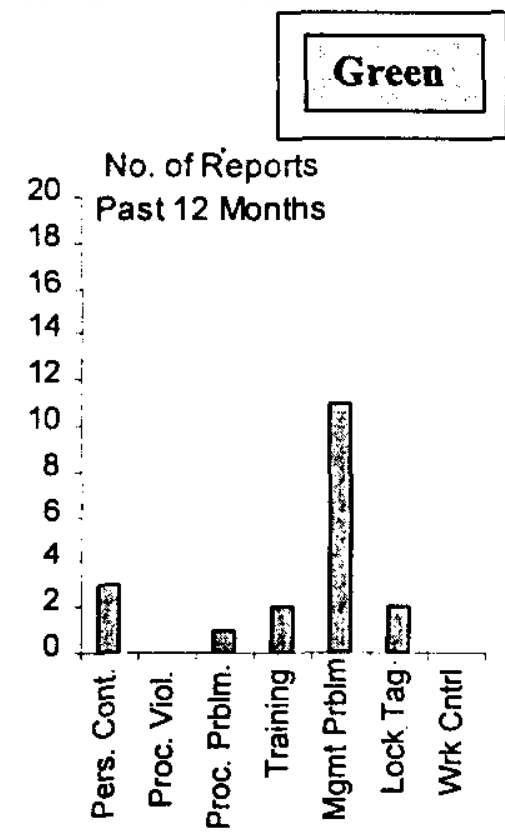

- $\quad$ Completed the appendices for Waste Management Project (WMP) / Analytical Services Project (ASP) which are a part of the FH System Description (FH MP-003). The System Description (SD) is the base document being assessed by the DOE Phase I Verification Team.

- The ISMS Self-Assessment data were combined into 22 groupings and 27 actions. Some are scheduled for completion before the end of Phase 1, some before the end of Phase II and some before the end of FY 2001.

- Training Session 4, "ISMS Verification and Your Role," is being finalized and will be presented to all employees before the start of Phase II verification.

- $\quad$ Completed the Authorization Agreements with one minor exception, which is being worked and should be complete by the end of Phase I verification.

- ISMS Workshop III complete.

\section{Planned Actions:}

- $\quad$ Complete Training Session 4 (ISMS Verification and Your Role)

- $\quad$ Revise and issue procedures and plans (based on Self-Assessment activity)

- Respond as necessary to Verification Team's findings regarding the SD's.

- Prepare and implement review process (including Senior Management Review Board) for Declaration of Readiness

- Declare Readiness

- Generate \& implement out-year plan to sustain and maintain ISMS effort 


\section{BREAKTHROUGHS / OPPORTUNITIES FOR IMPROVEMENT}

No Breakthroughs or Opportunities for Improvement are identified at this time.

\section{UPCOMING ACTIVITIES}

WIPP Certification and Waste Shipments - Complete Waste Isolation Pilot Project (WIPP) Certification of Hanford's TransUranic (TRU) Project and initiate TRU shipments in May 2000.

242A Evaporator Operations - Complete the 242-A Evaporator Campaign in May 2000 in support of the River Protection Project.

RH TRU PMP - Issue Project Management Plan (PMP) for RH TRU in June 2000 to meet M-91 milestone.

MLLW Treatment - Treat 1,160 cubic meters (includes 100 cubic meters stretch) of Mixed Low-Level Waste (MLLW) at Allied Technology Group (ATG) by August 2000; dispose of the Land Disposal Restriction compliant waste by September 2000.

Suspect TRU Waste Retrieval - Retrieve 425 drums of suspect TRU waste from the LowLevel Burial Grounds by September 2000.

Accelerate Readiness to Receive Spent Nuclear Fuel K Basin Sludge - Clear three sections of the T Plant Canyon deck in FY 2000 and complete entire deck clearing by FY 2001. Complete Project Execution Plan and Conceptual Design Document for removal of Shippingport Fuel from T Plant in FY 2000.

\section{Cost Performance $(\$ M):$}

\begin{tabular}{|l|c|c|c|}
\hline & BCWP & ACWP & VARIANCE \\
\hline Waste Management & $\$ 48.6$ & $\$ 48.6$ & $\$ 0.0$ \\
\hline
\end{tabular}

The cost variance is zero. Further information at the PBS level can be found in the following Cost Variance Analysis details. 


\section{SChedule Performance (\$M):}

\begin{tabular}{|l|c|c|c|}
\hline & BCWP & BCWS & VARIANCE \\
\hline Waste Management & $\$ 48.6$ & $\$ 51.4$ & $-\$ 2.8$ \\
\hline
\end{tabular}

The $\$ 2.8$ million (5 percent) unfavorable schedule variance is within established thresholds. Further information at the PBS level can be found in the following Schedule Variance Analysis details.

\section{FY 2000 Cost/Schedule Performance - All Fund Types Cumulative to Date Status - $(\$ 000)$}

\begin{tabular}{|c|c|c|c|c|c|c|c|c|c|c|c|c|c|}
\hline \multirow[b]{3}{*}{$\begin{array}{l}\text { PBS WM03 } \\
\text { WBS 1.2.1 }\end{array}$} & \multirow{3}{*}{$\begin{array}{l}\text { By PBS } \\
\text { Solid Waste Storage \& } \\
\text { Disposal }\end{array}$} & \multicolumn{11}{|c|}{ FYTD } & \multirow[b]{2}{*}{ PEM } \\
\hline & & \multicolumn{2}{|c|}{ Bcws } & \multicolumn{2}{|c|}{ BCWP } & \multicolumn{2}{|c|}{ ACWP } & \multicolumn{2}{|r|}{ sv } & $\%$ & CV & $\%$ & \\
\hline & & $\$$ & 17,658 & $\$$ & 17,601 & $\$$ & 16,501 & $\$$ & (57) & $0 \%$ & $\$ 1,101$ & $6 \%$ & $\$ 36,356$ \\
\hline $\begin{array}{l}\text { PBS WM04 } \\
\text { WBS 1.2.2 }\end{array}$ & Solid Waste Treatment & $\$$ & 13,554 & $\mathbf{s}$ & 12,397 & $\mathbf{s}$ & 14,252 & $\$$ & $(1,157)$ & $-9 \%$ & $\$(1,855)$ & $-15 \%$ & $\$ 30,124$ \\
\hline $\begin{array}{l}\text { PBS WM05* } \\
\text { WBS } 1.2 .3\end{array}$ & $\begin{array}{l}\text { Liquid Effluents - } \\
\text { 200/300 Area }\end{array}$ & $\$$ & 13,578 & $\$$ & 12,923 & $\mathbf{s}$ & 11,888 & $\$$ & (655) & $.5 \%$ & $\$ 1,035$ & $8 \%$ & $\$ 29,267$ \\
\hline $\begin{array}{l}\text { PBS TP02 WBS } \\
1.4 .2\end{array}$ & WESF & $\$$ & 6,614 & $\$$ & 5,688 & $\$$ & 5,946 & $\$$ & (926) & $-14 \%$ & $\$ \quad(258)$ & $-5 \%$ & $\$ 14,336$ \\
\hline & Total & $\mathbf{s}$ & 51,404 & $\mathbf{s}$ & 48,609 & $\boldsymbol{s}$ & 48,586 & $\mathbf{s}$ & $2,795)$ & $-5 \%$ & 23 & $0 \%$ & s 110,082 \\
\hline
\end{tabular}

* PBS WM05 includes the 300 Area Liquid Effluent, which is part of the River Corridor Project. 


\section{Cost/Schedule Performance Indices (MARCH 2000 AND FYTD)}

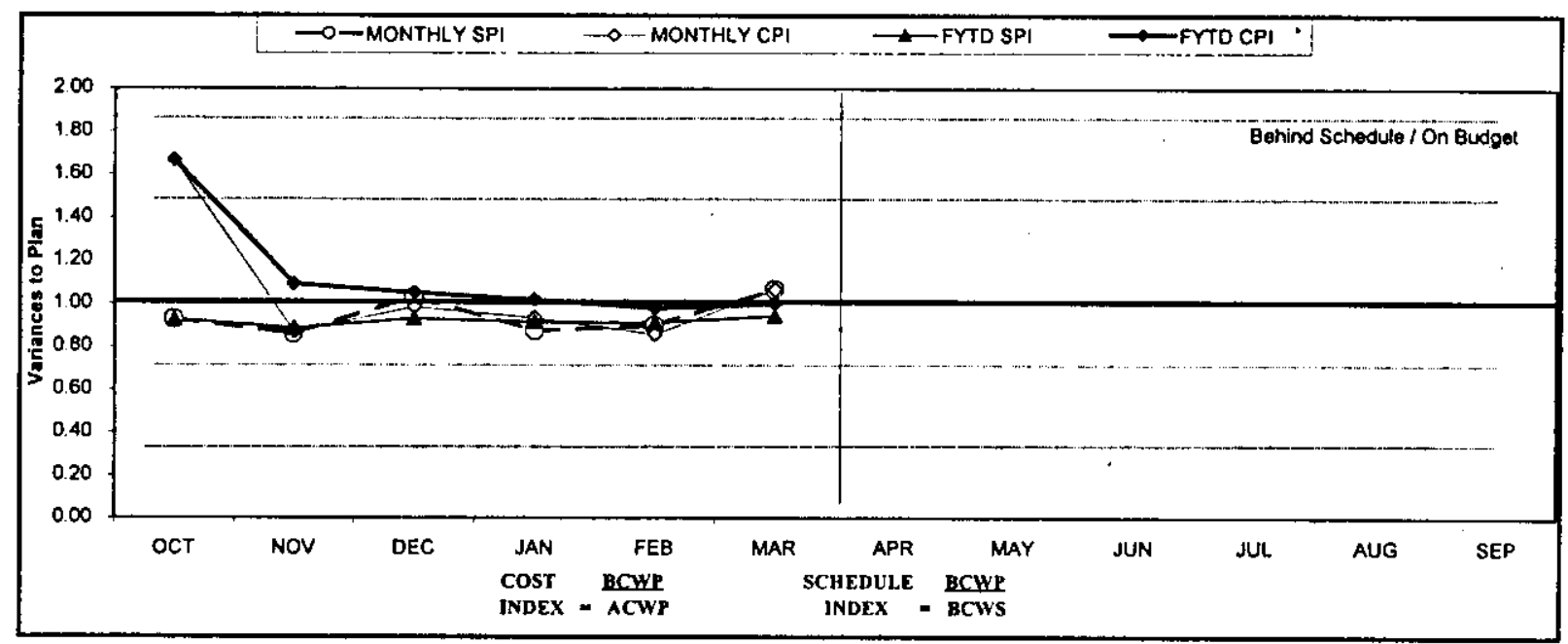

\begin{tabular}{|c|c|c|c|c|c|c|c|c|c|c|c|c|c|c|c|c|}
\hline FY 2000 & & OCT & & Nov & & DEC & & JAN & FEB & MAR & APR & MAY & JUN & JUL & AUC & SEP \\
\hline MONTHLY SPI & & 0.93 & & 0.86 & & 1.03 & & 0.88 & 0.90 & 1.07 & & & & & & \\
\hline MONTHLY CPI & & 1.66 & & 0.87 & & 0.98 & & 0.94 & 0.86 & 1.07 & & & & & & \\
\hline FYTD SPI & & 0.93 & & 0.89 & & 0.93 & & 0.92 & 0.91 & $0 . \overline{95}$ & & & & & & \\
\hline FYTD CPI & & 1.66 & & 1.09 & & 1.05 & & 1.02 & 0.98 & 100 & & & & & & \\
\hline MONTHLY BCWS & 5 & 6,641 & 5 & 9,616 & 5 & 7,269 & 5 & 8,331 & 8,862 & $10, \overline{886}$ & 8.804 & 10.979 & 8,170 & 8,091 & 10,757 & 11.877 \\
\hline MONTHLYBCWP & 5 & 6,163 & 5 & 8,277 & 5 & 7,499 & 5 & 7,291 & 7,973 & 11,406 & & & & & & \\
\hline MONTHL Y ACWP & $\mathbf{s}$ & 3,703 & 5 & 9,520 & 5 & 7.619 & 5 & 7,789 & 9,270 & 10,685 & & & & & & \\
\hline FYTD BCWS & 5 & 6,641 & 5 & 16.257 & 5 & 23,526 & 5 & 31,857 & 540,719 & 31,404 & $\$ 60.208$ & $\$ 71.187$ & 579.357 & 587,448 & 598,206 & S1 $10,0,02$ \\
\hline FYTD BCWP & $\mathbf{s}$ & 6,163 & 5 & 14,440 & 5 & 21,939 & 5 & 29,230 & 537,203 & 48,609 & & & & & & \\
\hline FYTD ACWP & 5 & 3,703 & 5 & 13,223 & $\mathbf{s}$ & 20,842 & 5 & 28,631 & 537,901 & 48.586 & & & & & & \\
\hline
\end{tabular}

\section{COST VARIANCE ANALYSIS: (\$0.0M)}

\section{$\underline{\text { WBS/PBS }} \quad \underline{\text { Title }}$}

\subsection{1/WM03 Solid Waste Storage \& Disposal}

Description/Cause: The favorable cost variance of $\$ 1.1 \mathrm{M}(6$ percent) is within the established threshold.

Impact: No impact.

Corrective Action: No corrective action required.

\subsection{2/WM04 Solid Waste Treatment}

Description/Cause: The unfavorable cost variance of $\$ 1.9 \mathrm{M}(15$ percent) is due to Canyon Deck Clean Off workscope being performed under an Advanced Work Authorization (AWA) for T Plant support to accelerated SNF sludge removal. In addition, there are retooling and TRU project recertification costs caused by the new WIPP permit changes.

Impact: No impact.

Corrective Action: A BCR has been submitted to reflect the additional workscope for T Plant and the TRU Project. 


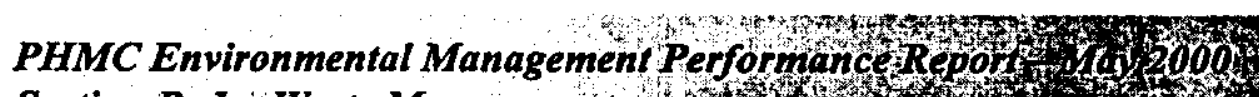

Section B: 1 -Waste Management

1.2.3.1/WM05

Liquid Effluents

Description/Cause: The favorable cost variance of $\$ 1.0 \mathrm{M}$ ( 8 percent) is within the established threshold.

Impact: No impact.

Corrective Action: No corrective action required.

\subsection{2/TP02 WESF}

Descripti $n$ /Cause: The unfavorable cost variance of $\$ 0.3 \mathrm{M}$ (5 percent) is due to unplanned activities for the Ultrasonic Test (UT) of Cesium capsules and electrical system upgrades.

Impact: No impact.

Corrective Action: The variance will be managed in the Corrective Maintenance budget.

\section{SCHEDUle VARIANCE ANALYSIS: (- \$2.8M)}

\section{WBS/PBS}

1.2.1/ WM03

Description /Cause: The unfavorable schedule variance is less than $1 \%$, which is within the established threshold.

Impact: . No Impact.

Corrective Action: No corrective action required.

\subsection{2/ WM04}

Solid Waste Treatment

Description /Cause: The unfavorable schedule variance of $\$ 1.2 \mathrm{M}$ (9\% percent) is due to the delay in TRU production and shipments, which is a result of WIPP permit changes and re-certification. MLLW treatment is behind schedule due to ATG not completing construction on their facility as scheduled.

Impact: No Impact.

Corrective Action: ATG processing began in late December 1999. The schedule will be recovered. TRU production is in the process of rebaselining to resolve WIPP certification audit comments and reworking the shipment schedule.

\subsubsection{1/WM05}

Liquid Effluents

Description /Cause: The unfavorable schedule variance of $\$ 0.7 \mathrm{M}$ ( $5 \%$ percent) is within the established thresholds.

Impact: No Impact.

Corrective Action: No corrective action required.

\subsection{2/ TP02}

WESF

Description /Cause: The unfavorable schedule variance of $\$ 0.9 \mathrm{M}$ (14\% percent) is due to the deferral of the FSAR to FY 2002 to resolve DOE funding reductions.

Impact: No Impact.

Corrective Action: A BCR has been approved and will be implemented in the April baseline. 


\section{ISSUES \\ TECHNICAL ISSUES}

Nothing to report at this time.

\section{DOE/REGULATOR/EXTERNAL ISSUES}

The Waste Management Programmatic Environmental Impact Statement (PEIS) was issued on February 25, 2000. These Records of Decision (ROD) for LLW and MLLW will affect Hanford's disposal role for the Complex and the ROD outcomes may have a significant impact on disposal volumes and rates at Hanford. DOE-HQ and WDOE negotiations continue; impacts depend upon results of these negotiations.

Certification of Hanford's TRU Project is necessary to initiate waste shipment to WIPP. Continue working with the Carlsbad Area Office, the Environmental Protection Agency (EPA) and the New Mexico Environment Department (NMED) to achieve WIPP certification of Hanford's TRU Project and initiate waste shipment to WIPP.

The State of Washington Department of Ecology issued a Final Determination (FD) regarding the "recent" dispute over the scope of the annual Land Disposal Restriction (LDR) report and TPA Milestone M-26-01. This FD contains a number of requirements for "improvement" of the LDR report, i.e. format and content changes. DOE-RL subsequently issued an advanced work authorization to $\mathrm{FH}$ to complete an Implementation Plan and Baseline Change Request for a Hanford Mixed Waste (MW) Management Program and including the Final Determination requirements in that program. Progress to date includes:

- $\quad$ Conducting multi-contractor team meetings to define scope and issues associated with this effort.

- Drafted definition of "waste stream" for inclusion in the LDR report and MW program.

- Defined path forward, budget estimate and schedule for development of the implementation plan.

- Drafted white paper regarding the proposed scope for both the 2000 and 2001 LDR submittals.

- Initiated preparation of Basis of Estimates (BOEs) for proposed new scope. 


\section{Baseline Change Requests Currently in Process \\ (\$000)}

\begin{tabular}{|c|c|c|c|c|c|c|c|c|c|}
\hline $\begin{array}{l}\text { PROJECT } \\
\text { CHANGE } \\
\text { NUMBER } \\
\end{array}$ & $\begin{array}{c}\text { DATE } \\
\text { ORIGIN. }\end{array}$ & BCR TITLE & $\begin{array}{c}\text { FYO0 } \\
\text { COST } \\
\text { IMPACT } \\
\text { SO00 } \\
\end{array}$ & SCH & TECH & $\begin{array}{c}\text { DATE } \\
\text { TOCCB } \\
\end{array}$ & $\begin{array}{c}\mathbf{C C B} \\
\text { APR'VD } \\
\end{array}$ & RL APR'VD & $\begin{array}{l}\text { CURRENT } \\
\text { STATUS }\end{array}$ \\
\hline WM-2000-002 & $1 / 5 / 00$ & $\begin{array}{l}\text { Waste Management FY } 2000 \text { Mandated } \\
\text { Funds Reduction }\end{array}$ & $-\$ 3,042$ & & & $02 / 17 / 00 \mid$ & $03 / 29 / 00$ & & At DOE-RL \\
\hline FSP-2000-018 & $1 / 25 / 00$ & $\begin{array}{l}\text { WESF Mandated Funds Reduction } \\
\text { T-PJant Canyon Deck Clean off and PWR }\end{array}$ & $-\$ 1,100$ & & & $02 / 29 / 00$ & $02 / 29 / 00$ & & Approved \\
\hline WM-2000-003 & $2 / 8 / 00$ & Fuel Removal & $\$ 3,085$ & & & $4 / 13 / 200$ & $04 / 13 / 00$ & & At DOE-RL \\
\hline WM-2000-004 & $2 / 8 / 00$ & WMP Stretch Goals & so & & & TBD & & & Draft at DOE-RL \\
\hline WM-2000-0005 & $3 / 21 / 00$ & WMP FY 2000 Repricing Impacts & $\$ 653$ & & & TBD & & & Draft at DOE-RL \\
\hline FSP-2000-030 & $3 / 21 / 00$ & WMP FY 2000 Repricing Impacts & (\$653) & & & TBD & & & Draft at DOE-RL \\
\hline \multicolumn{10}{|c|}{ ADVANCE WORK AUTHORIZATIONS } \\
\hline $\begin{array}{l}\text { AWA } \\
\text { AWA }\end{array}$ & $\begin{array}{l}2 / 24 / 00 \\
2 / 25 / 00\end{array}$ & $\begin{array}{l}\text { T Plant Canyon Deck cleanoutPWR Fuel } \\
\text { Removal } \\
\text { TRU Retrieval/TRU PMP }\end{array}$ & $\begin{array}{l}\$ 1,650 \\
\$ 555\end{array}$ & & & & & $\begin{array}{l}04 / 06 / 00 \\
04 / 06 / 00\end{array}$ & $\begin{array}{l}\text { Acceleration of } \\
\text { scope } \\
\text { Acceleration of } \\
\text { scope }\end{array}$ \\
\hline
\end{tabular}

\section{WASTE MANAGEMENT - WBS 1.2 MILESTONE ACHIEVEMENT}

\begin{tabular}{|c|c|c|c|c|c|c|c|c|}
\hline \multirow[b]{2}{*}{ MILESTONE TYPE } & \multicolumn{4}{|c|}{ FISCAL YEAR-TO-DATE } & \multicolumn{3}{|c|}{ REMAINING SCHEDULED } & \\
\hline & $\begin{array}{c}\text { Completed } \\
\text { Early }\end{array}$ & $\begin{array}{c}\text { Completed On } \\
\text { Schedule }\end{array}$ & $\begin{array}{l}\text { Completed } \\
\text { Late }\end{array}$ & Overdue & $\begin{array}{l}\text { Forecast } \\
\text { Early }\end{array}$ & $\begin{array}{c}\text { Forecast On } \\
\text { Schedule }\end{array}$ & $\begin{array}{l}\text { Forecast } \\
\text { Late }\end{array}$ & $\begin{array}{l}\text { TOTAL } \\
\text { FY } 2000\end{array}$ \\
\hline Enforceable Agreement & 1 & 0 & 0 & 0 & $\overline{0}$ & 1 & 0 & 2 \\
\hline DOE-HQ & 0 & 0 & 0 & 0 & 0 & 0 & 0 & 0 \\
\hline $\mathbf{R L}$ & 0 & 0 & 0 & 0 & 0 & 9 & 0 & 9 \\
\hline Total Project & 1 & 0 & 0 & 0 & 0 & 10 & 0 & 11 \\
\hline
\end{tabular}

Tri-Party Agreement TEA Milestones

\begin{tabular}{|l|l|l|}
\hline \multicolumn{1}{|c|}{ Number } & \multicolumn{1}{|c|}{ Milestone Title } & \multicolumn{1}{c|}{ Status } \\
\hline $\begin{array}{l}\text { M-91-03 } \\
\text { (WMH-00- } \\
\text { 001) }\end{array}$ & $\begin{array}{l}\text { Issue TRU/TRUM } \\
\text { Waste PMP }\end{array}$ & due 06/30/00 - On schedule (stretch) \\
\hline $\begin{array}{l}\text { M-91-04 } \\
\text { (A2J-00-001) }\end{array}$ & $\begin{array}{l}\text { Complete Construction } \\
\text { of CH TRU/TRUM } \\
\text { Retrieval Facility }\end{array}$ & $\begin{array}{l}\text { due 09/29/00 - DOE-RL issued a letter to Ecology on February 29, } \\
\text { 2000 documenting closure of the TPA milestone as retrieval has been } \\
\text { initiated and is planned to continue, even without construction of } \\
\text { Project W-113 facilities. }\end{array}$ \\
\hline & & \\
\hline
\end{tabular}

\section{DNFSB Commitments}

Nothing to report. 


\section{MILESTONE EXCEPTION REPORT}

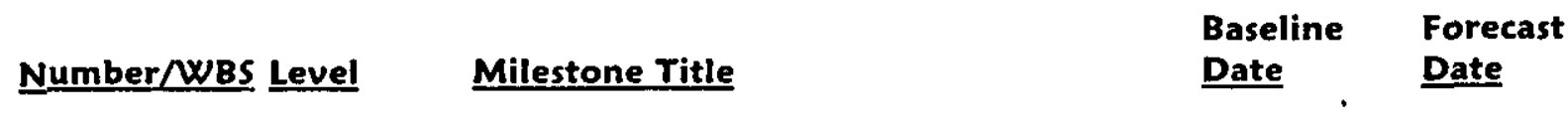

\section{OVERDUE - 0}

\section{FORECAST LATE - 0}

\section{FY 1999 OVERDUE - 1}

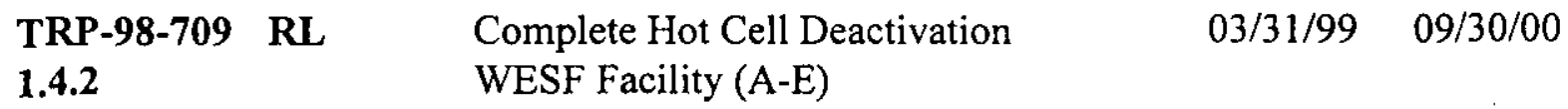

Cause: This milestone is not complete due to not being supported at the current funding level. Impact: No overall impact is expected.

Corrective Action: Return-on Investment (ROI) funding has been identified for this work scope and a new forecasted completion date of September 30, 2000 established. 
Performance Objectives MLLW TREATMENT

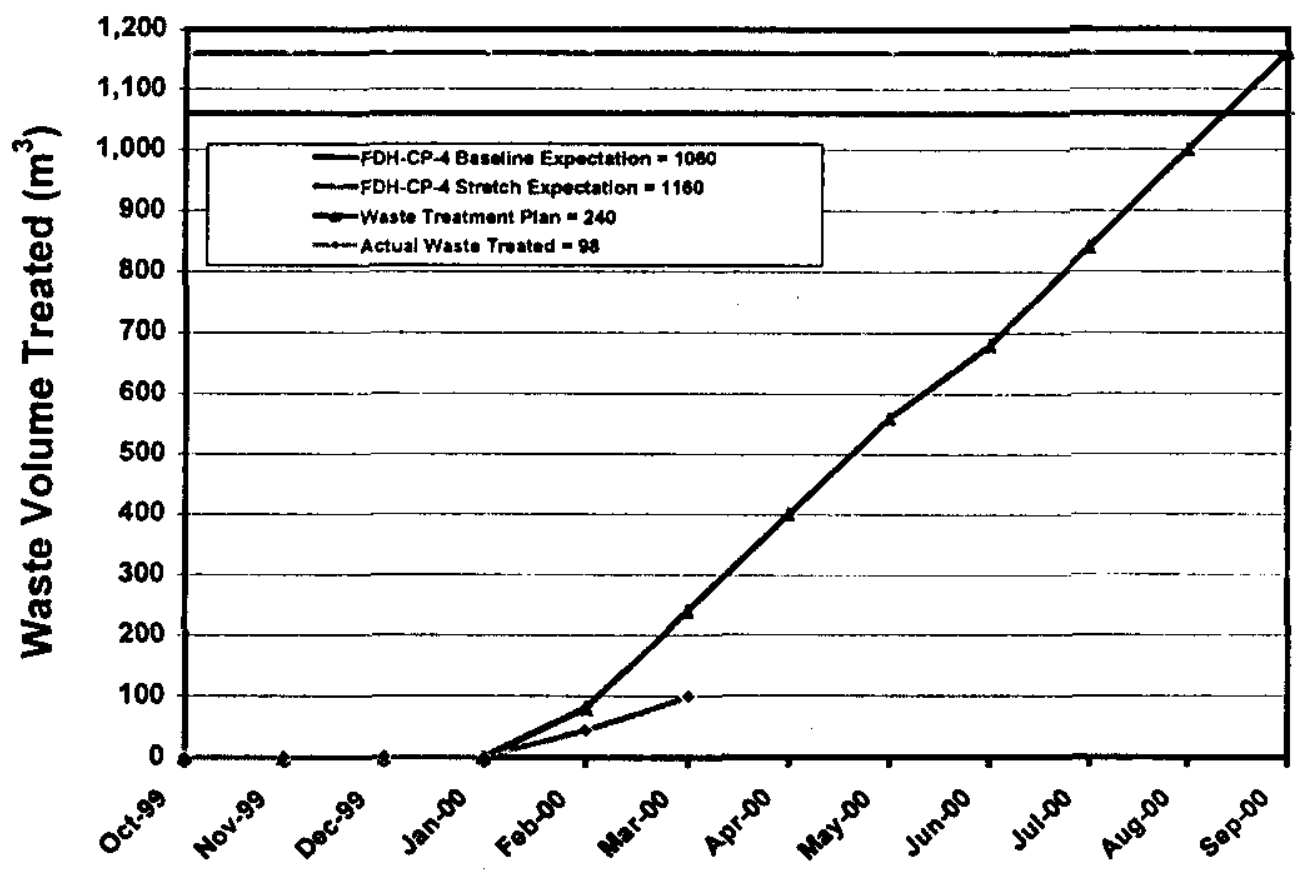

Action Plans: Reduced to yellow this month due to being significantly behind schedule.

Corrective actions are in place with the performing subcontractor to completely recover schedule (additional personnel assigned).

MLLW DISPOSAL

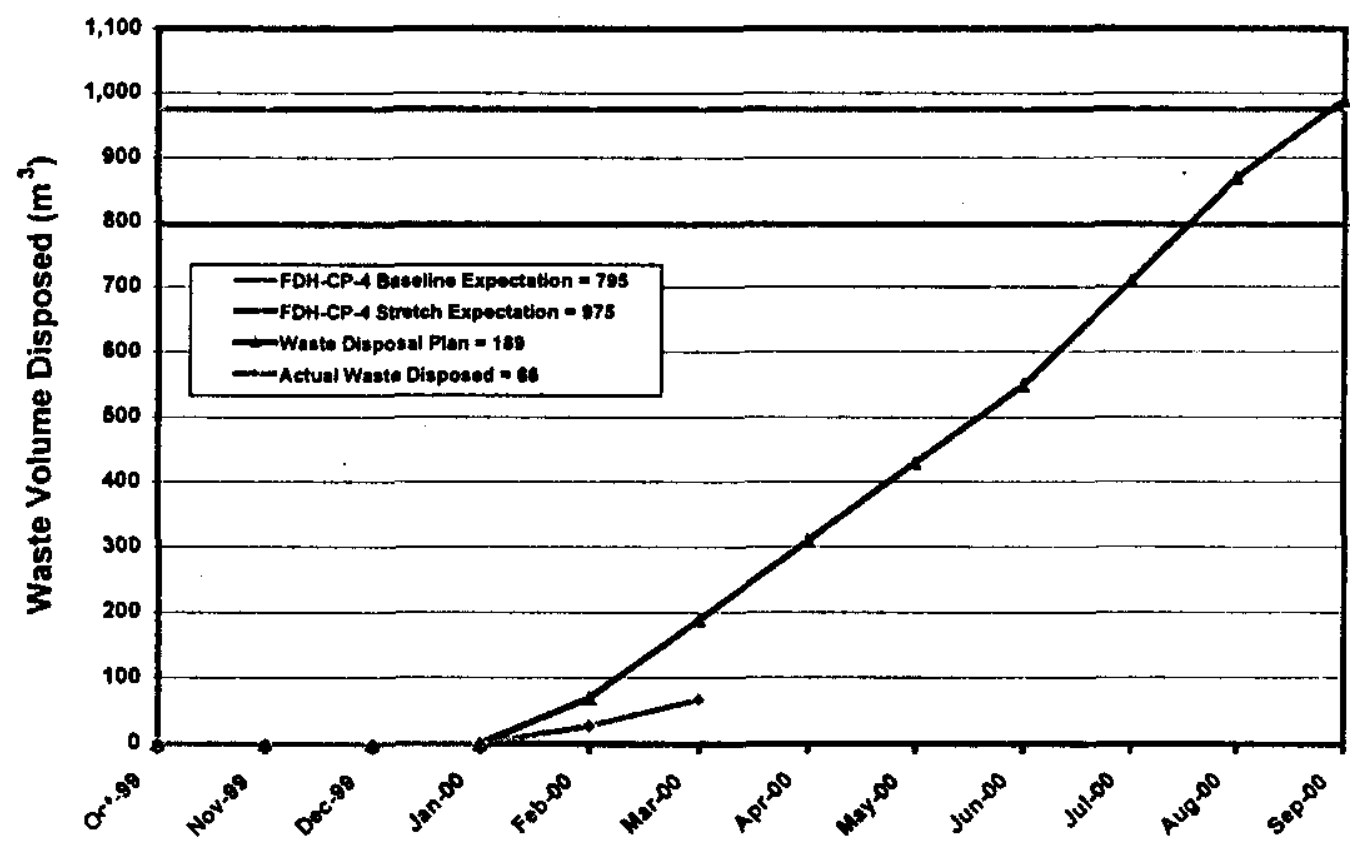

Yellow

ACTION Plans: Reduced to yellow this month due to being significantly behind schedule.

Corrective actions are in place with the performing subcontractor to completely recover schedule (additional personnel assigned). 


\section{TRU RETRIEVAL}

\section{Green}
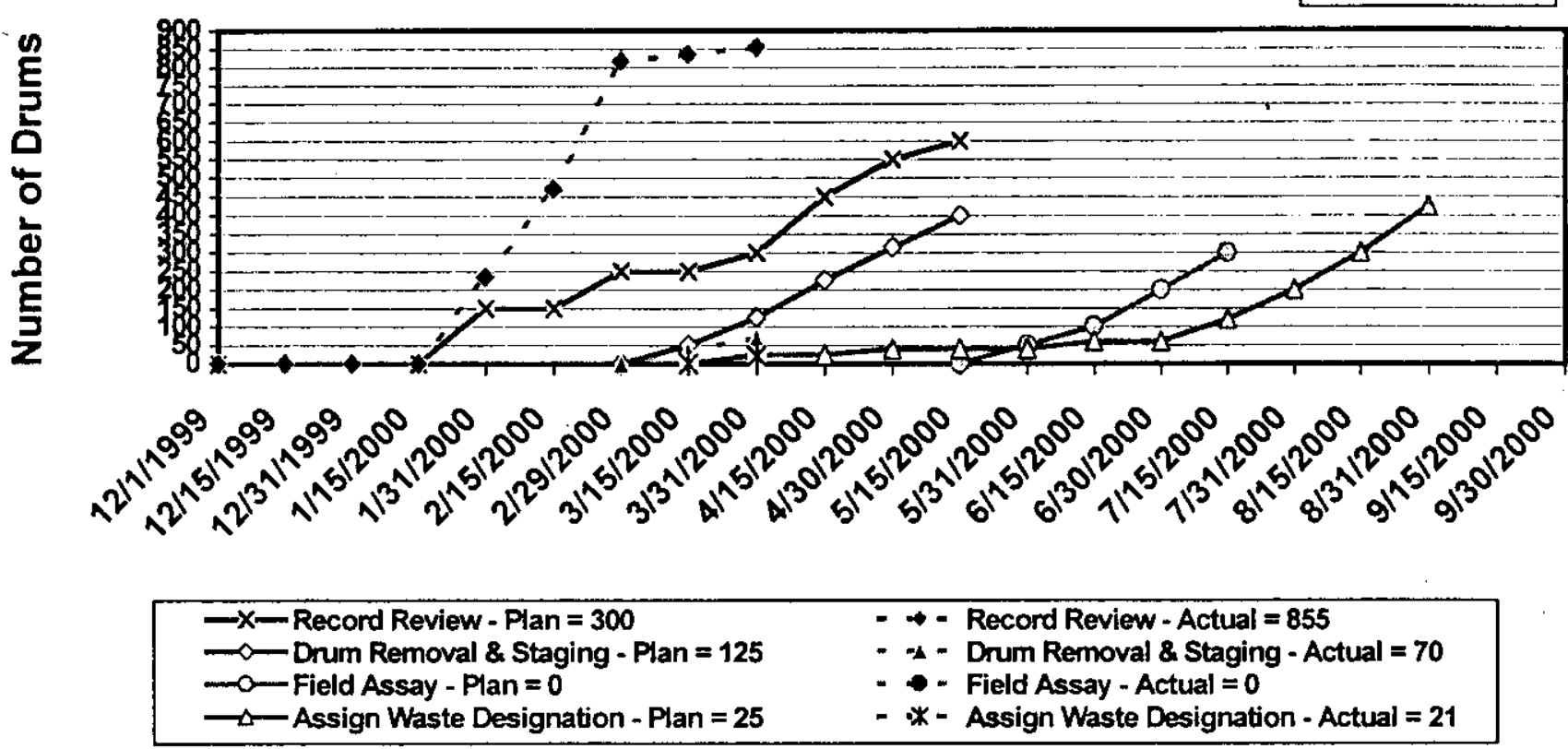

Action Plans: On track. Retrieved 70 drums from the stack and designated 21 drums as TRU waste. The 49 remaining drums require assay before designation as TRU or low-level waste. The revised performance incentive (FDH-CP-3, Measure 1) has been finalized, and the new stretch goal for drums designated is 425 .

\section{TRU Container Processing}

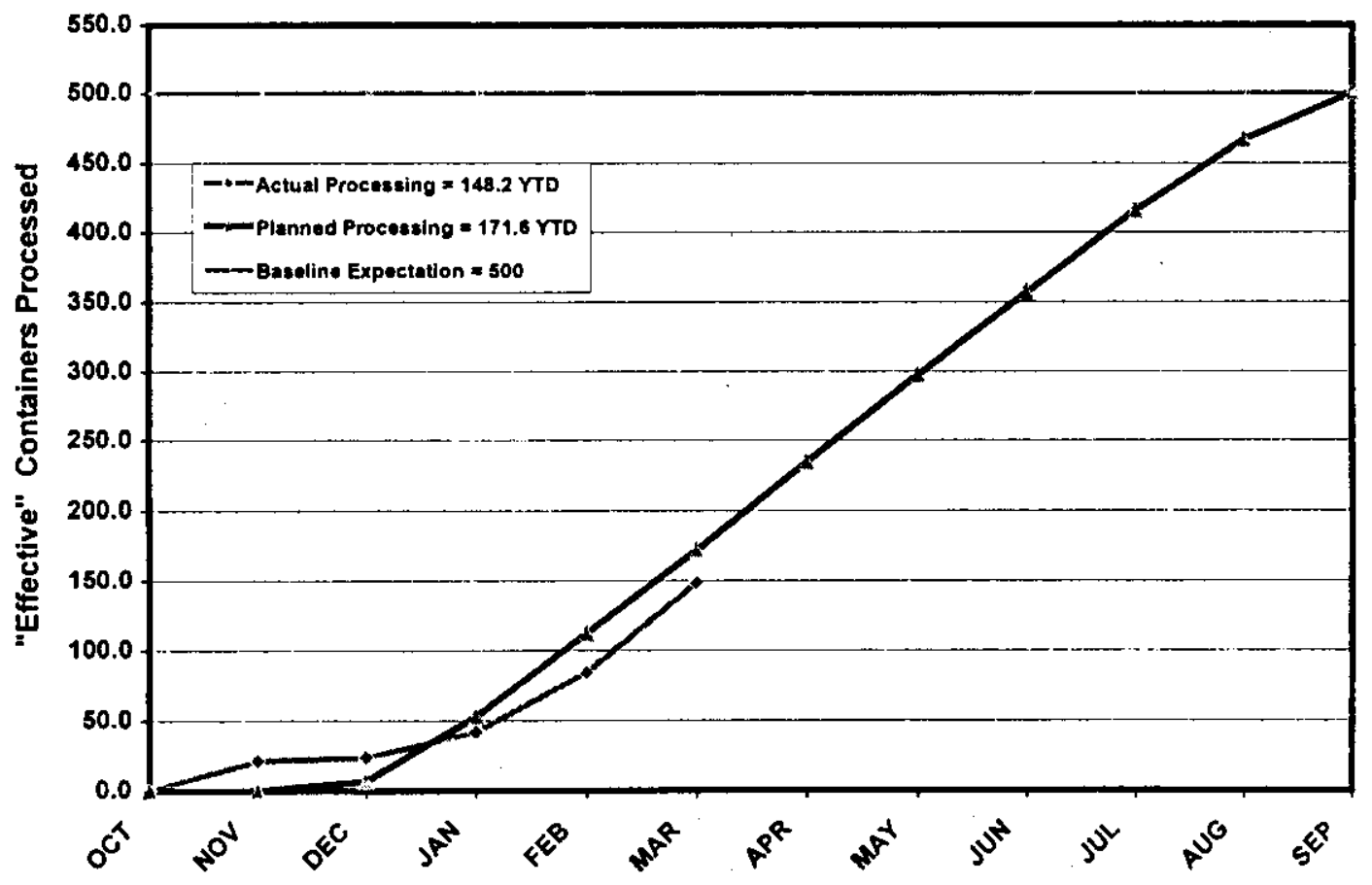

Action Plans: Change/negotiation required pending $\mathrm{CAO}$ audit results. 
TRU SHIPMENTS

\section{Green}

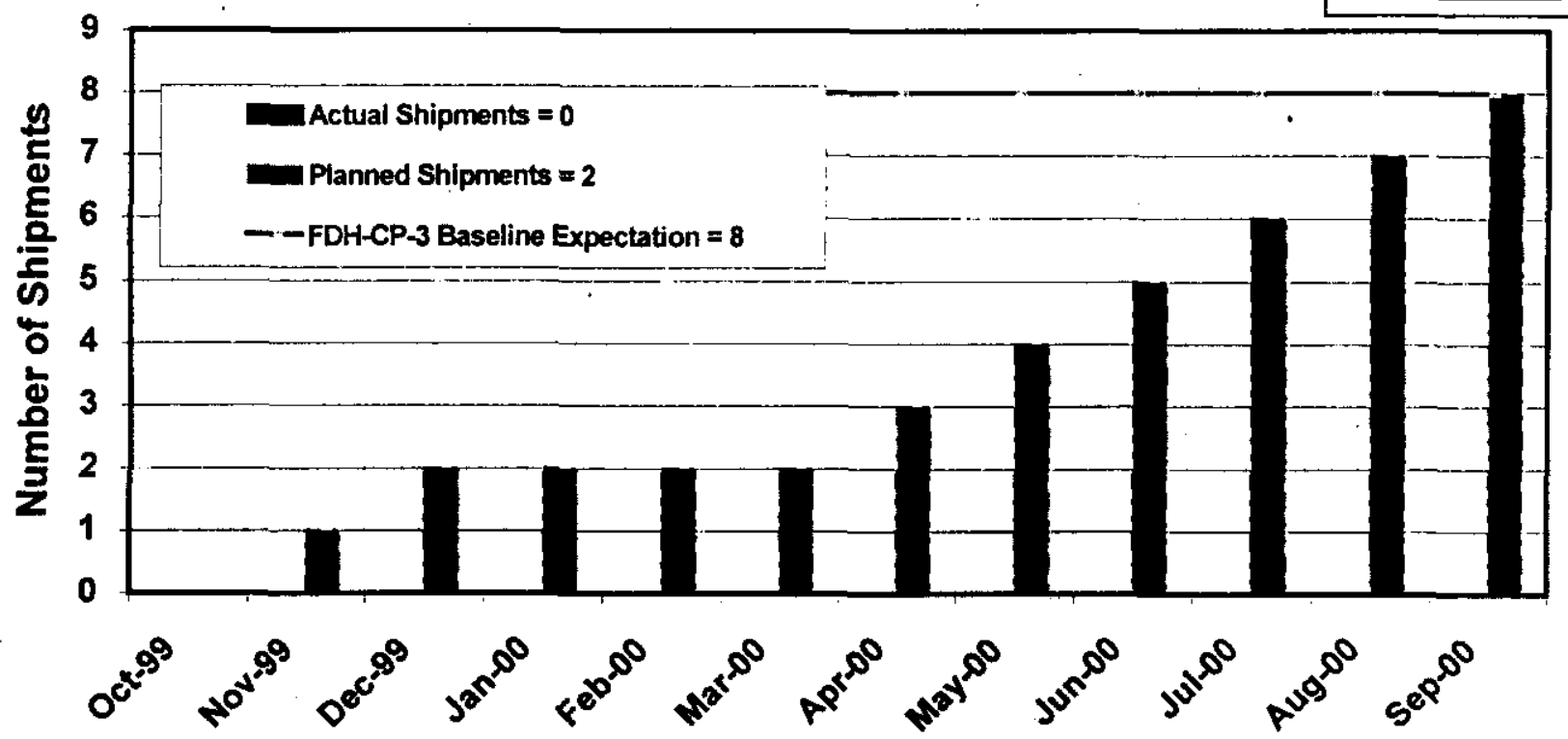

Action Plans: Change required based on additional CAO WIPP Certification requirements. Initial shipment delayed until spring 2000.

\section{LIRUID WASTE Processing}
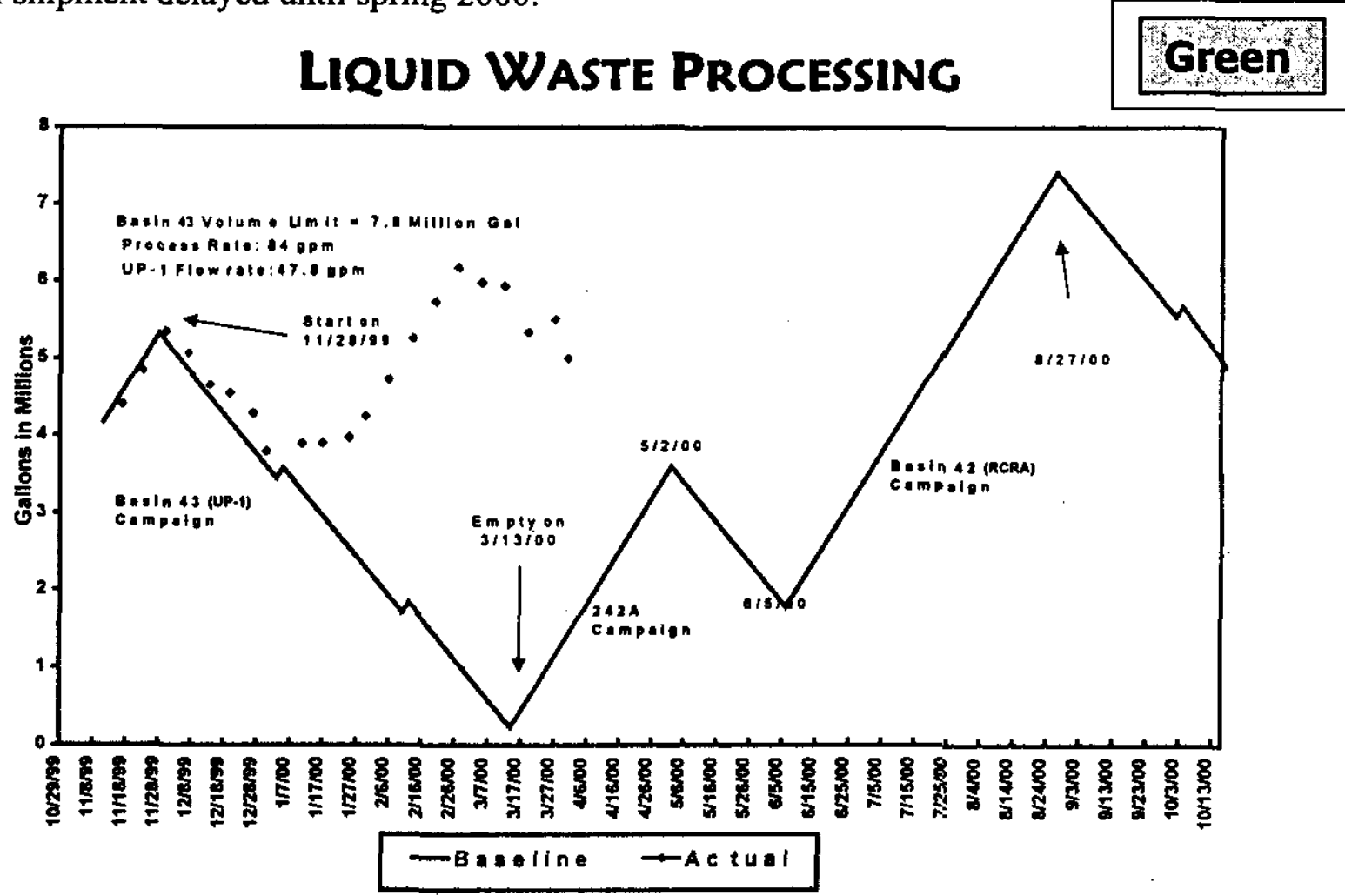

Action Plans: Production plans are being adjusted to incorporate incremental 242A Evaporator operations. Change negotiation required for the RCRA campaign. 


\section{KEY INTEGRATION ACTIVITIES}

- $\quad$ Preparing T Plant to receive Spent Nuclear Fuel K Basin sludge.

- Issuance of Records of Decision for LLW and MLLW is expected to affect Hanford's role in disposing of waste from other sites. Define Hanford's role as one of the identified LLW/MLLW disposal sites for the Complex working with DOE-RL, DOE-HQ, WDOE and other Sites.

- $\quad$ Support continued for UP-1 Groundwater treatment with BHI and increased RPP evaporator feed volumes.

- $\quad$ Support River Corridor Project in cleanup and removal of waste from 324 and 327 buildings.

- Support DOE-RL declaration of Readiness-to-Proceed in support of the Office of River Protection (ORP) Privatization contract.

- Working with PNNL, EM 50 and Mixed Waste Focus Area (MWFA) to obtain funding in support of mixed waste processing.

- $\quad$ Participated in the DOE Order 435.1 ("Radioactive Waste Management") workshop with other DOE and Contractor site representatives to share issues, lessons learned, and paths forward in complying with the Order.

- Continue to work with DOE- RL, -Oakland, and -Ohio to support resolution of TRU small quantity site disposition issues. 


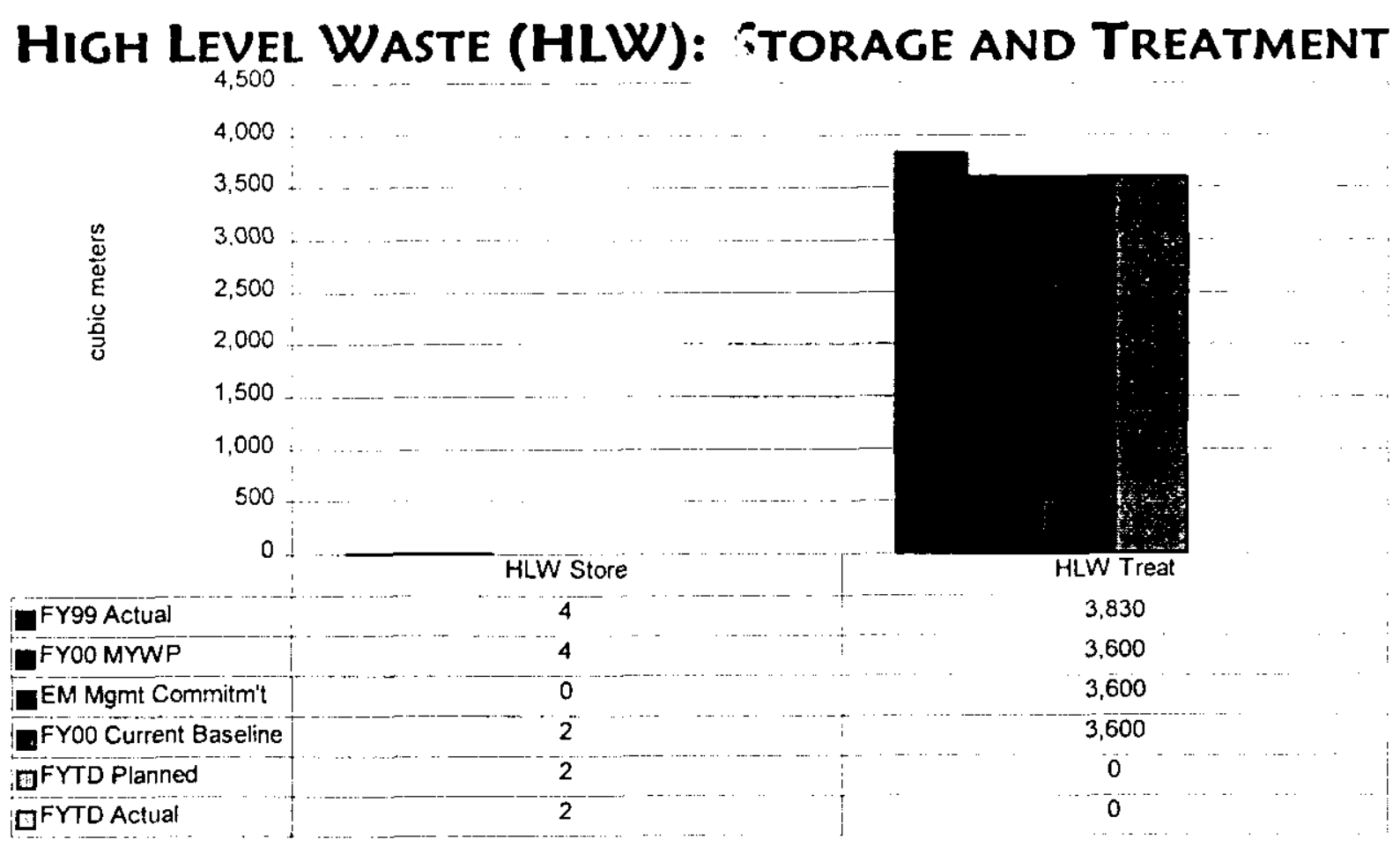

Storage: The HLW inventory of the Cesium (Cs) and Strontium 90 (Sr) capsules stored in the Waste Encapsulation and Storage Facility (WESF) pool cells has been adjusted to provide a consistent reporting basis. The previously reported 4 cubic meters was based on the capsule dimensions. However, the reported HLW inventory should included the volume that is HLW (i.e., the Cs and Sr salt), which is 2 cubic meters. The HLW Cs and Sr salt volume will be the basis for future reporting.

Treatment: No treatment planned this quarter. The evaporator campaign for treatment of high-level tank waste for the year is scheduled to be completed in May. 


\section{TransUranic (TRU) Waste: Storage, Treatment and Disposal}

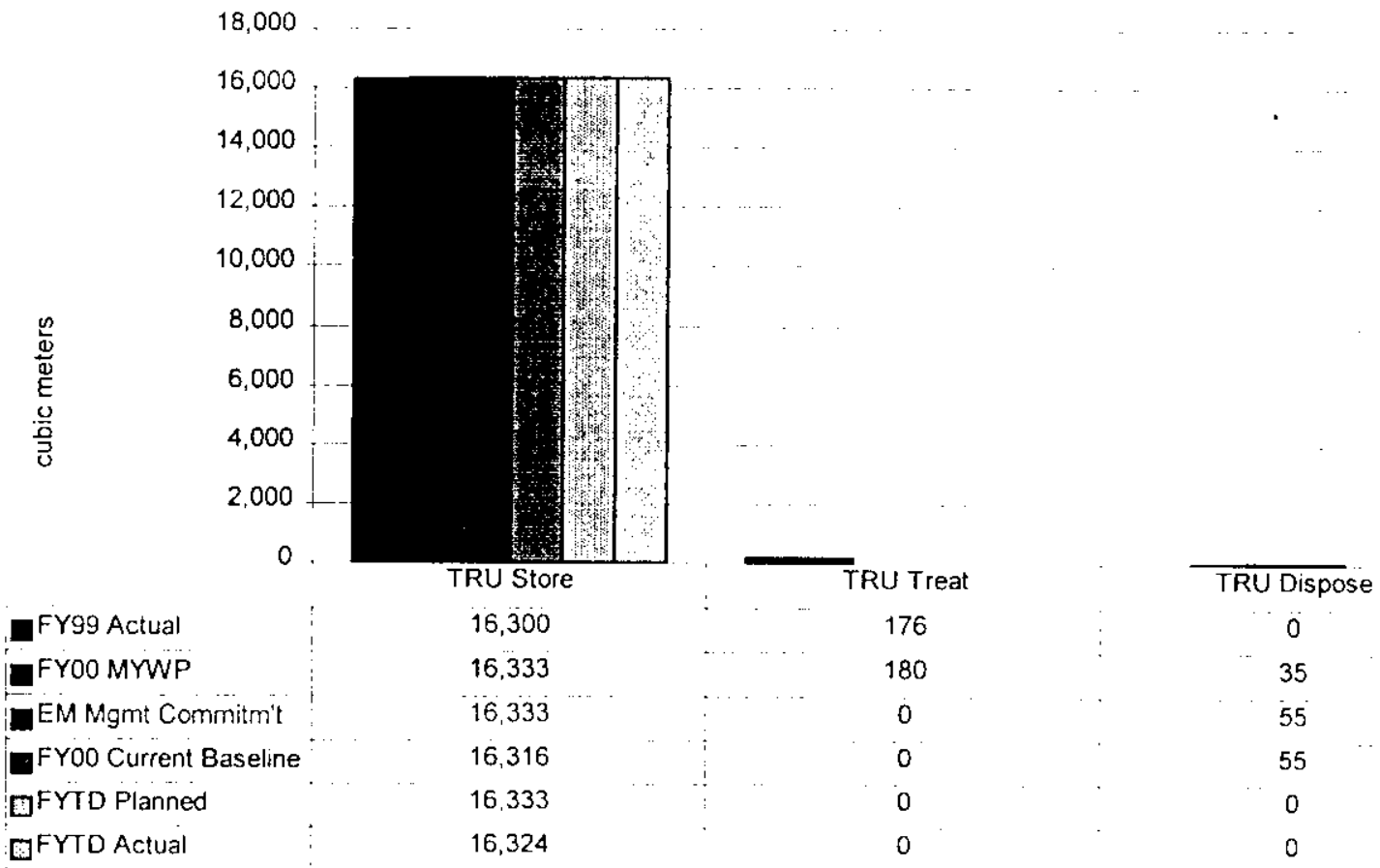

Storage: Storage continues to be provided for existing and newly generated TRU waste. The current volume of TRU in storage is within $10 \%$ of the planned amount.

Treatment: Based on DOE-HQ guidance, TRU processing at WRAP does not meet the revised TRU treatment definition. Therefore, TRU treatment volumes previously identified in the FY00 MYWP have been set to zero.

Disposal: None scheduled this period. 


\section{Mixed Low leVel Waste: Storage, Treatment, AND DISPOSAL}

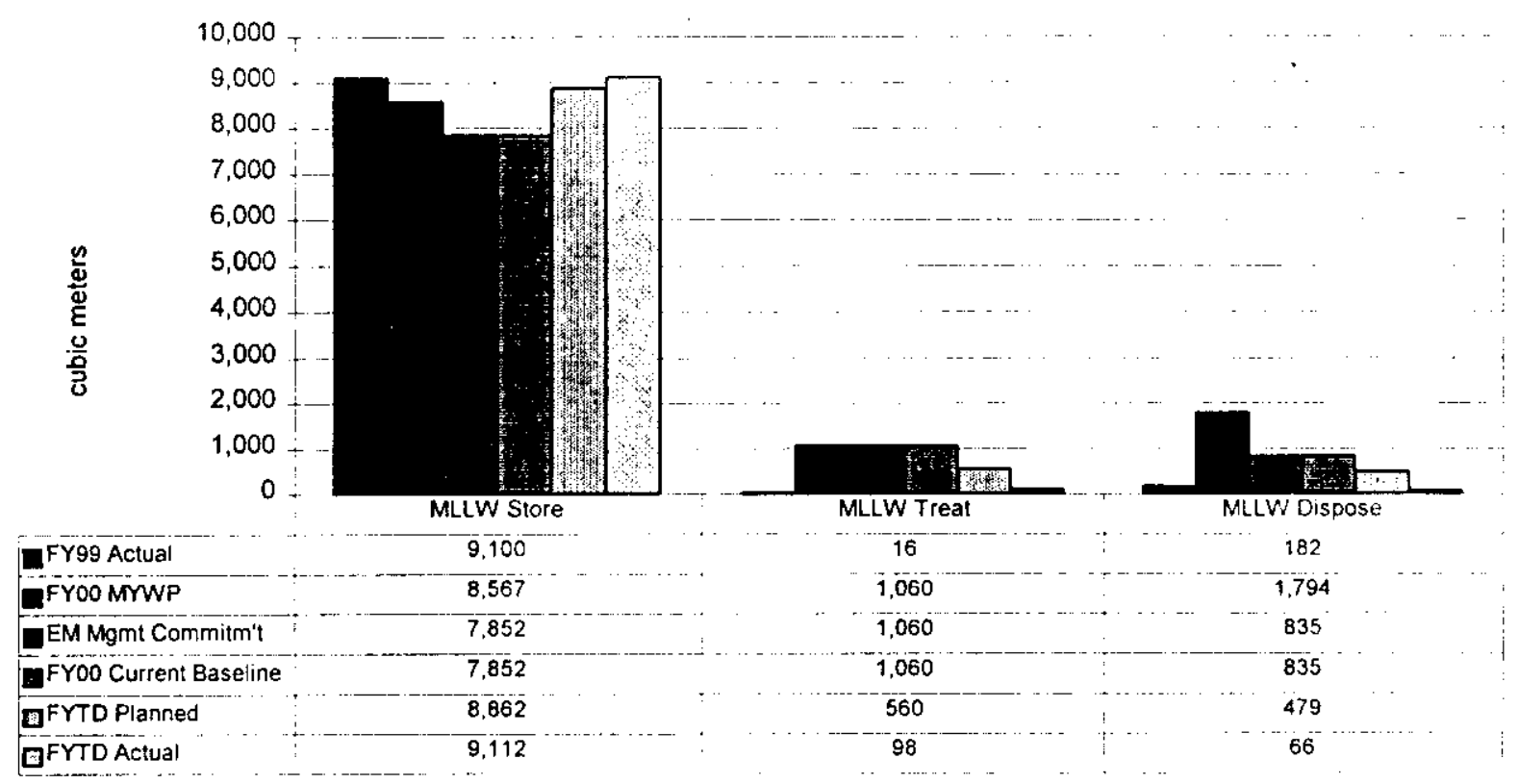

Storage: Storage continues to be provided for existing and newly generated MLLW waste. The current volume of MLLW in storage is within $10 \%$ of the planned amount.

Treatment: Allied Technology Group (ATG) is behind in delivering acceptance paperwork to $\mathrm{FH}$, thus there is a backlog of waste awaiting treatment acceptance from ATG. ATG states that they will recover the schedule by June 2000 .

Disposal: Correction to first quarter disposed quantity: There was no disposal of MLLW for the first quarter. The 182 cubic meters reported was erroneously carried over from FY1999. There were 66 cubic meters disposed of during the second quarter. Planned disposal quantity estimates after treatment/repackaging were reduced by 38 percent, which accounts for 81 cubic meters of the lower disposal rate. The remaining difference is due to the slip in waste treatment acceptance noted above. 


\section{Low LeVel Waste (LLW): Storage, Treatment, AND Disposal}

Low Level Waste as of March 31, 2000

$$
\begin{aligned}
& \frac{\omega}{9} \\
& \stackrel{0}{0} \\
& E \\
& \frac{0}{J} \\
& \hline 0
\end{aligned}
$$

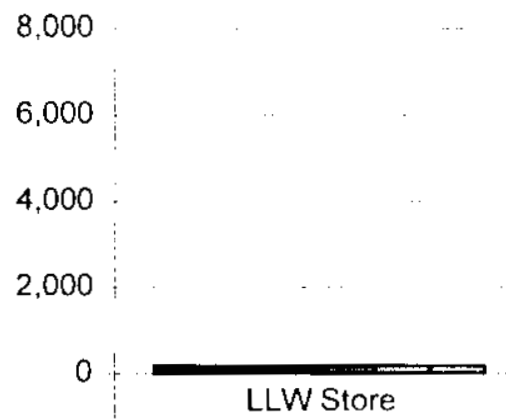

FY99 Actual

180

DFYOO MYWP

180

180

EM Mgmt Commitm't

DFYOO Current Baseline

180

DFYTD Planned

180

LLW Treat

0

0

0

0

0

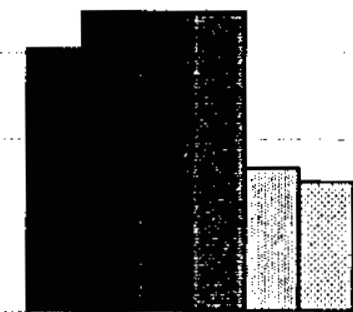

LLW Dispose

6,080

6,936

6,936

6,936

3,328

Storage: Storage remains unchanged for LLW not suitable for disposal. Contracting for commercial treatment of this waste is planned for FY2007.

Treatment: No treatment of LLW is planned until after FY2006 when a treatment alternative has been selected. All newly generated LLW receipts are prepared and packaged to the waste acceptance criteria for disposal of LLW in the burial grounds and no further treatment is required.

Disposal: Shipments are now being received from Argonne National Laboratory and Battelle Columbus and disposal is within $10 \%$ of the plan amount. 

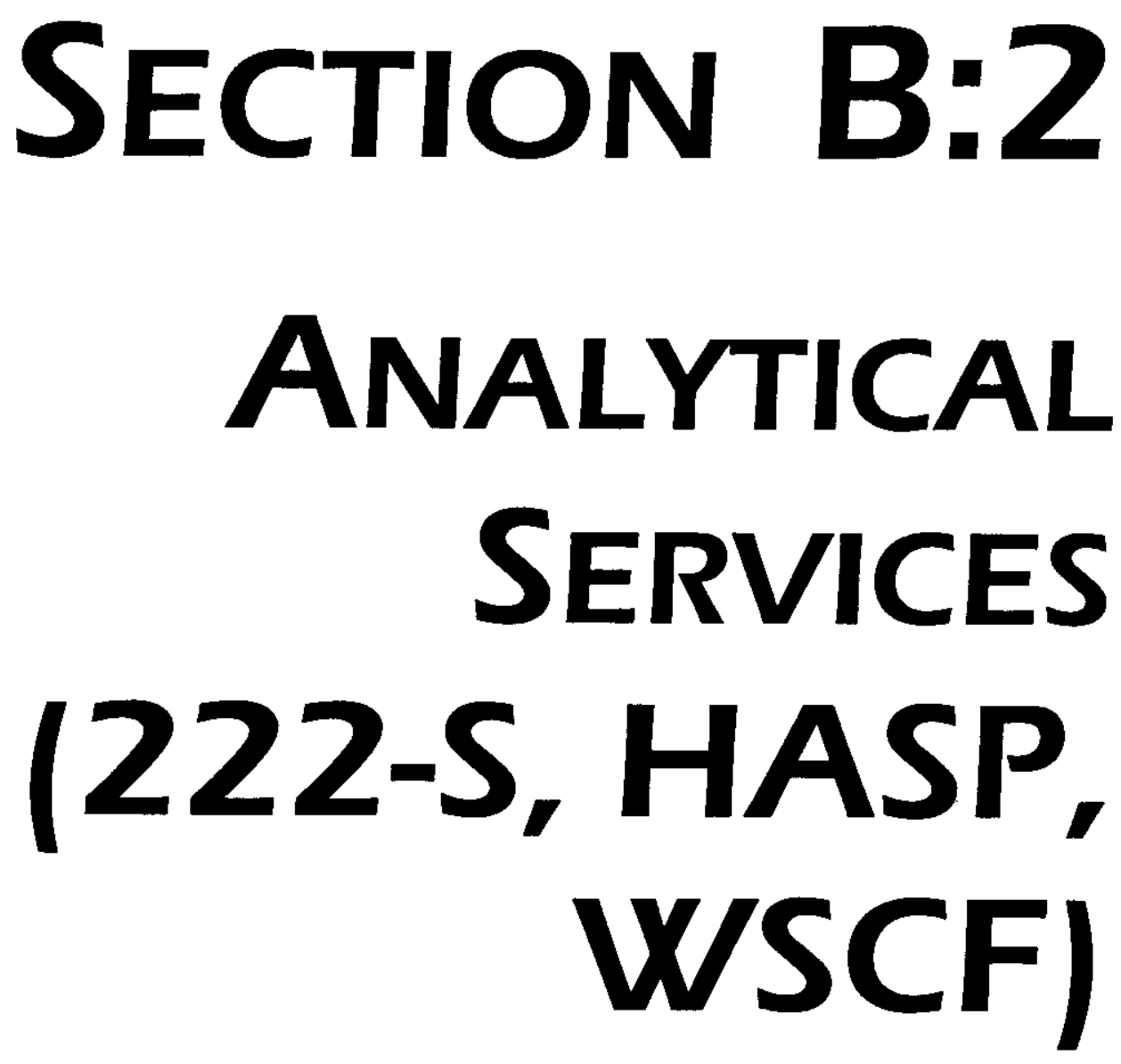

PROJECT MANAGERS

S. H. Wisness, RL

Phone: (509) 373-9337

D.L. Renberger, FH

Phone: (509) 372-0877 


\section{SUMMARY}

Analytical Services [222-S, Hanford Analytical Services Program (HASP), Waște Sampling and Characterization Facility (WSCF)] consists of Analytical Services, PBS WM06, WBS 1.2.4.

NOTE: Unless otherwise noted, the Safety, Conduct of Operations, Milestone Achievement, and Cost/Schedule data contained herein is as of March 31, 2000. Other information is updated as noted.

Fiscal-year-to-date-milestone performance (EA, DOE-HQ and RL) shows no milestones are due this reporting period.

\section{ACCOMPLISHMENTS}

- March analytical output has been high, with a total of 6.4 Analytical Equivalent Units (AEUs) processed at the 222-S Laboratory through April 21, 2000 (FYTD) in support of the RPP (TWRS) tank characterization program (versus 6.9 AEUs planned). Recent reports issued include AY-102 Safety Screen Results, and U-106 and SY-102 Compatibility Results.

- $\quad$ Procedures, methods, equipment, and training were significantly revised to meet the new WIPP permit from the State of New Mexico. Supported closure of the Corrective Action Reports (CARs) from the Carlsbad Area Office audit of the Hanford TRU Project. Performed 8,700 analyses (FYTD) through March 24, 2000 at WSCF for a wide variety of customers as planned.

\section{SAFETY}

In March, there were no OSHA recordable cases, no lost/restricted days and 2 first aid cases. The project continues to focus on safety and personal and team accountability. The four-month trend is a positive indication for performance during the second half of FY 2000. 
10

8

6

4

2

0

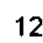

12 OSHA Recordable Case Rate

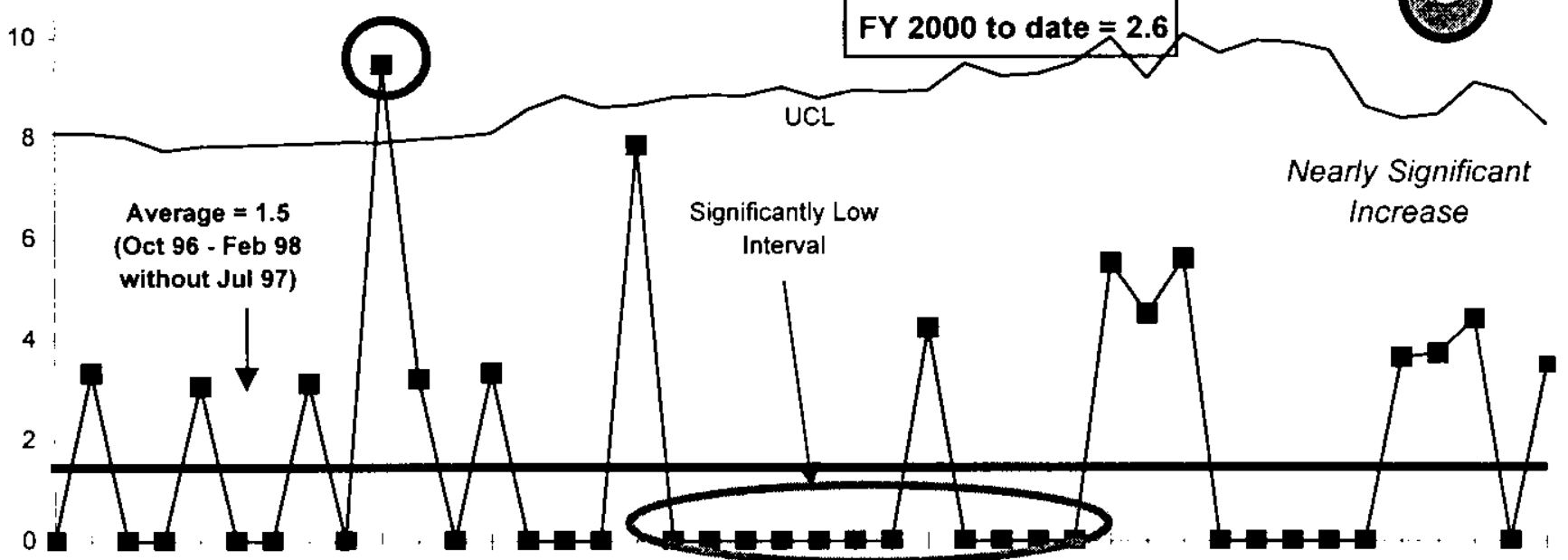

80. DOE Safety Cost Index

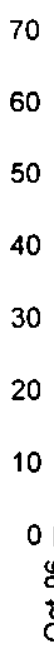

60
50
40
30
20
10
0
8
8

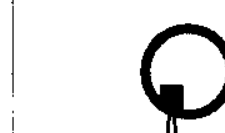

i
FY 2000 to date $=1.3$

$1,600,000$ hours without

Oct 96 - Apr 99)

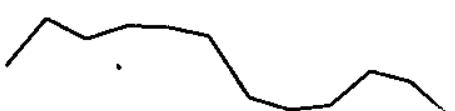

Average $=1.4$

(Apr 99 - Nov 99)

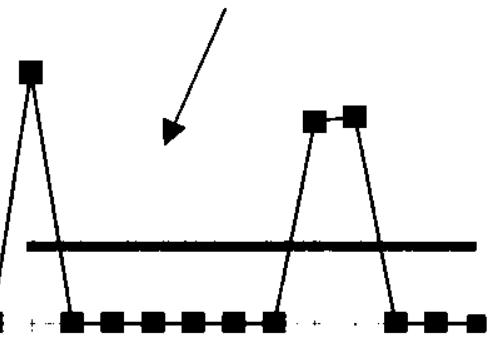




\section{CONDUCT OF OPERATIONS / ISMS STATUS CONDUCT OF OPERATIONS}
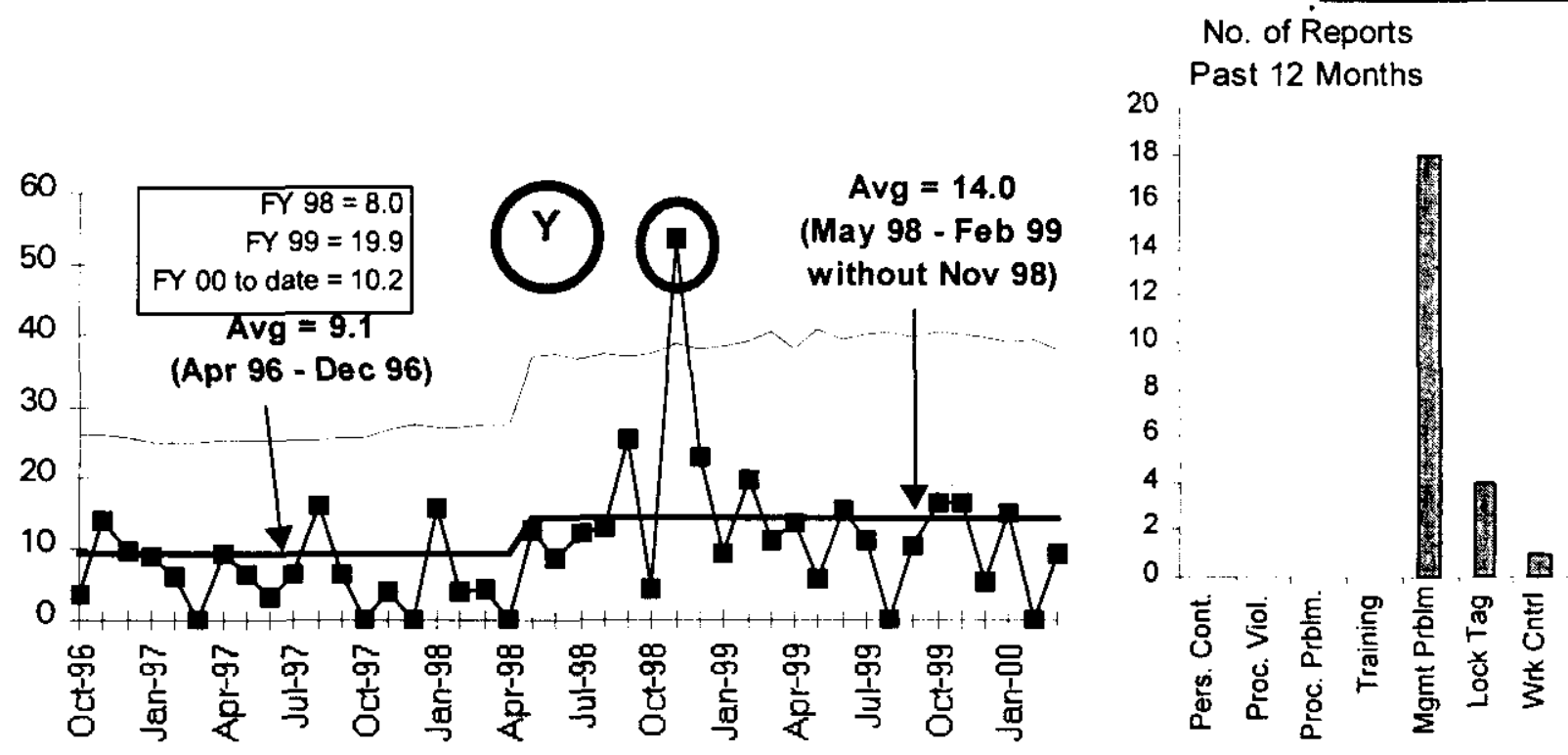

ISMS STATUS

Green

Analytical Services ISMS status is included in the Waste Management Project Section of this report. Overall, on track for the June 2000 Phase II verification.

\section{BREAKTHROUGHS / OPPORTUNITIES FOR IMPROVEMENT}

No breakthroughs or opportunities for improvement were identified at this time.

\section{UPCOMING ACTIVITIES}

WIPP Certification and Waste Shipments -- Continue headspace gas analysis in support of the Hanford TRU Project and waste shipment to WIPP.

242A Evaporator Operations - Support the April/May campaign.

ORP Readiness to Proceed - It has been determined that Analytical Services is prepared to support the readiness to proceed decision for the BNFL contract. Key follow-up actions are:

- Formal specification of requirements from ORP to RL and then to FH

- Stable funding of needed equipment and facility repair in Multi-Year Work Plans (RL and ORP)

- Funding replacement of obsolete laboratory support systems (Information Management)

- Funding of staff to maintain core competency. 


\section{Cost Performance (\$M):}

\begin{tabular}{|l|c|c|c|}
\hline & BCWP & ACWP & VARIANCE \\
\hline Analytical Services & $\$ 13.4$ & $\$ 14.2$ & $-\$ 0.8$ \\
\hline
\end{tabular}

The $\$ 0.8$ million (6 percent) unfavorable cost variance is due to increased cost for $222-\mathrm{S}$

Laboratory polychlorinated biphenyl $(\mathrm{PCB})$ recovery and increased resources required to support compliance issues.

\section{Schedule Performance ( $\$ M)$ :}

\begin{tabular}{|l|c|c|c|}
\hline & BCWP & BCWS & VARIANCE \\
\hline Analytical Services & $\$ 13.4$ & $\$ 13.7$ & $-\$ 0.3$ \\
\hline
\end{tabular}

The $\$ 0.3$ million (2 percent) unfavorable schedule variance is within the established threshold.

\section{FY 2000 Cost/SChedule Performance - All Fund Types Cumulative to Date Status - $(\$ 000)$ \\ By PBS

\begin{tabular}{llllllll}
\hline BCWS & BCWP & ACWP & SV & $\%$ & CV & $\%$ & PEM
\end{tabular}

WBS

1.2.4 Analytical

WM06 Services $\quad$\begin{tabular}{llllllllll}
$\$ 13,693$ & $\$ 13,421$ & $\$ 14,193$ & $\$(272)$ & $-2 \%$ & $\$(772)$ & $-6 \%$ & $\$ 27,818$ \\
\hline
\end{tabular}

Total $\quad \begin{array}{lllllllllll}\$ 13,693 & \$ 13,421 & \$ 14,193 & \$(272) & -2 \% & \$(772) & -6 \% & \$ 27,818\end{array}$ 


\section{Cost/Schedule Performance Indices (MARCH 2000 AND FYTD)}

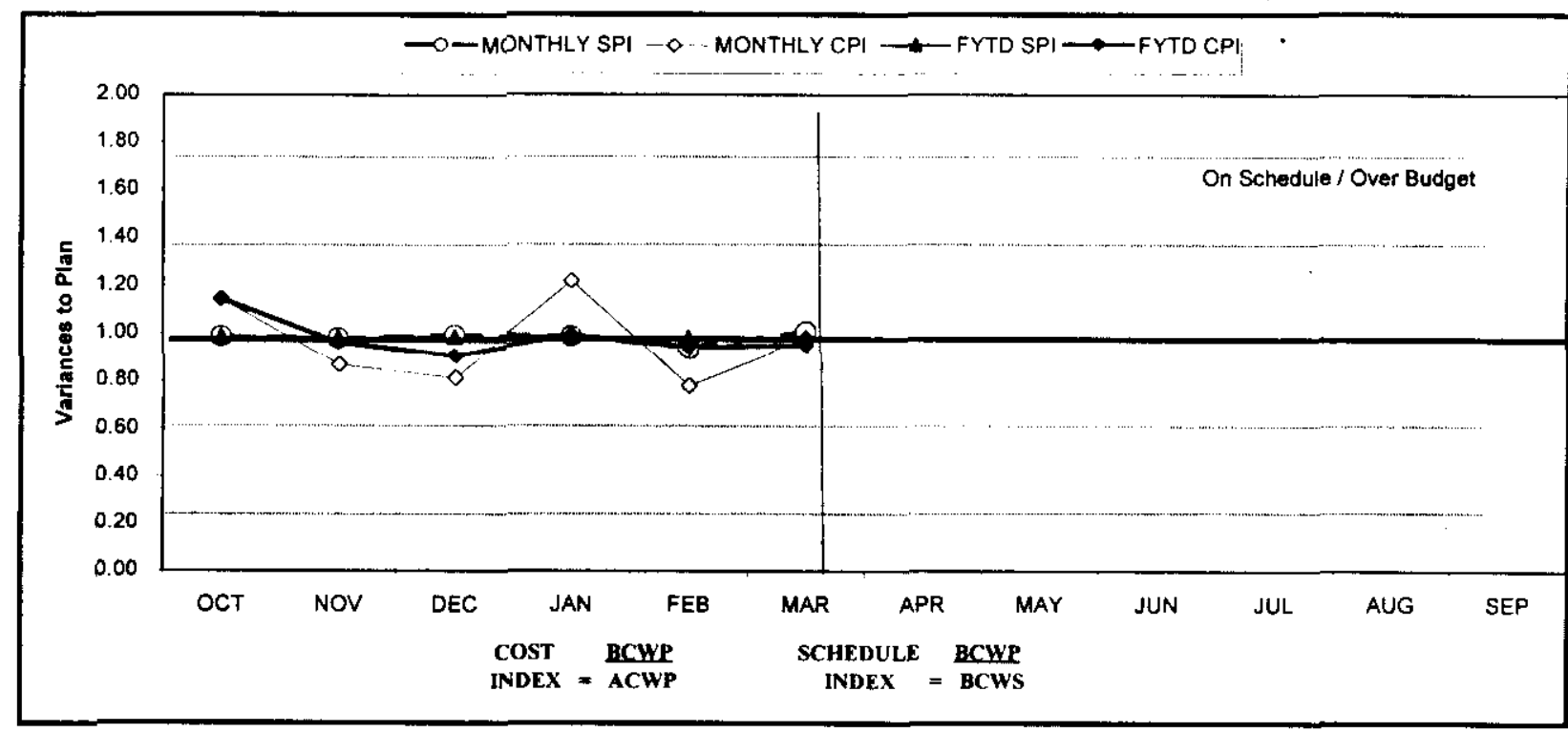

\begin{tabular}{|c|c|c|c|c|c|c|c|c|c|c|c|c|}
\hline FY 2000 & OCT & NOV & DEC & JAN & FEB & MAR & APR & $\mathbf{M A Y}$ & JUN & JUL & AldG & SEP \\
\hline MONTHLY SPI & 0.99 & 0.98 & 0.99 & 0.98 & 0.94 & 1.00 & & & & & & \\
\hline MONTHLY YPI & 1.14 & 0.87 & 0.81 & 1.22 & 0.78 & 0.98 & & & & & & \\
\hline FYID SPI & 0.99 & 0.98 & 0.99 & 0.98 & 0.97 & 0.98 & & & & & & \\
\hline FYTD CPI & 1.14 & 0.96 & 0.91 & 0.99 & 0.94 & 0.95 & & & & & & \\
\hline MONTHLY BCWS & $\$ 1,588$ & $\$ 2,340$ & 51,973 & $\$ 2,896$ & $\$ 2,283$ & $\$ 2,613$ & $\$ 2.279$ & $\$ 2,67,3$ & $\$ 1,990$ & $\$ 1.984$ & $\$ 2,581$ & $\$ 2,617$ \\
\hline MONTHLY BCWP & $\$ 1,566$ & $\$ 2,288$ & $\$ 1,960$ & $\$ 2,848$ & $\$ 2,135$ & $\$ 2,624$ & & & & & & \\
\hline MONTHLY ACWP & $\$ 1,369$ & $\$ 2,640$ & $\$ 2,414$ & $\$ 2,342$ & $\$ 2,741$ & $\$ 2,686$ & & & & & & \\
\hline FYTD BCWS & $\$ 1,588$ & $\$ 3,928$ & 55,901 & $\$ 8,797$ & $\$ 11,080$ & $\$ \$ 3,693$ & $\$ 15,973$ & $\$ 18.646$ & $\$ 20,635$ & $\$ 22,620$ & 525,201 & $\$ 27.818$ \\
\hline FYTD BCWP & $\$ 1,566$ & $\$ 3,854$ & $\$ 5,814$ & $\$ 8,662$ & $\$ 10,797$ & $\$ 13,421$ & & & & & & \\
\hline FYTD ACWP & $\$ 1,369$ & $\$ 4,009$ & $\$ 6,423$ & $\$ 8,765$ & $\$ 11,506$ & $\$ 14,193$ & & & & & & \\
\hline
\end{tabular}

\section{COST VARIANCE ANAlysis: $(-\$ 0.8 \mathrm{M})$}

\section{WBS/PBS}

\subsection{4/WM06}

Description/Cause: The unfavorable cost variance of $\$ 0.8$ million (5.8 percent) is due to increased costs for 222-S Tank 104 poly-chlorinated biphenyl recovery activities; increased resources in support of compliance issues, ISM implementation, corrective action management, and chemical technologist training development.

Impact: Current yearend spending projections indicate a $\$ 1.3 \mathrm{M}$ overrun.

Corrective Action: Corrective actions have been identified and implemented to control spending. Due to the unforeseen significant extra costs for PCB management, $\mathrm{FH}$ senior management is reviewing whether full recovery to budget will be necessary. 


\section{SCHEDULE VARIANCE ANALYSIS: (- \$0.3M)}

WBS/PBS

\subsection{4/WM06}

established threshold.

Impact: None

Corrective Action: None required.

\section{Title}

Analytical Services

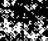

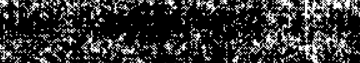

\section{ISSUES}

\section{Technical Issues}

Issues were self-identified in the WSCF laboratory's conformance to certain customers' (200 ETF, $300 \mathrm{TEDF}$ ) permit-mandated regulatory protocols (sample digestion, holding times and accreditation status). Impacts could be discharge permit violations depending on the type of samples. A regulatory penalty is unlikely. Corrective actions are being taken in each area and customers have been notified to enable impact assessment. Rework of all useable archived samples is complete.

\section{DOE/Regulator/External Issues}

Nothing to report.

\section{Baseline Change Requests Currently in Process (\$000)}

\begin{tabular}{|c|c|c|c|c|c|c|c|c|c|}
\hline $\begin{array}{l}\text { PROJECT } \\
\text { CHANGE } \\
\text { NUMBER }\end{array}$ & $\begin{array}{l}\text { DATE } \\
\text { ORIGIN. }\end{array}$ & BCR TITLE & $\begin{array}{c}\text { FYo0 } \\
\text { COST } \\
\text { IMPACT } \\
\text { S000 }\end{array}$ & $\mathrm{SCH}$ & TECH & $\begin{array}{c}\text { DATE } \\
\text { TO CCB }\end{array}$ & 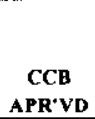 & RL APR'VD & $\begin{array}{l}\text { CURRENT } \\
\text { STATUS }\end{array}$ \\
\hline WM-2000-002 & $1 / 3 / 00$ & $\begin{array}{l}\text { Waste Management FY } 2000 \text { Mandated } \\
\text { Funds Reduction }\end{array}$ & $-\$ 879$ & & & $02 / 17 / 00$ & & & $\begin{array}{l}\text { BCR submitted to } \\
\text { RL for review } \\
\text { and approval. }\end{array}$ \\
\hline \multicolumn{10}{|c|}{ ADVANCE WORK AUTHORIZATIONS } \\
\hline & & Nothing to report at this time. & & & & & & & \\
\hline
\end{tabular}




\section{ANALYTICAL SERVICES - WBS 1.2.4 \\ Milestone ACHIEVEMENT}

\begin{tabular}{|c|c|c|c|c|c|c|c|c|}
\hline \multirow[b]{2}{*}{ MILESTONE TYPE } & \multicolumn{4}{|c|}{ FISCAL YEAR-TO-DATE } & \multicolumn{3}{|c|}{ REMAINING SCHEDULED } & \multirow[b]{2}{*}{$\begin{array}{l}\text { TOTAL } \\
\text { FY } 2000\end{array}$} \\
\hline & $\begin{array}{c}\text { Completed } \\
\text { Early }\end{array}$ & $\begin{array}{c}\text { Completed } \\
\text { On } \\
\text { Schedule }\end{array}$ & $\begin{array}{c}\text { Completed } \\
\text { Late }\end{array}$ & Overdue & $\begin{array}{c}\text { Forecast } \\
\text { Early }\end{array}$ & $\begin{array}{c}\text { Forecast } \\
\text { On } \\
\text { Schedule }\end{array}$ & $\begin{array}{c}\text { Forecast } \\
\text { Late }\end{array}$ & \\
\hline Enforceable Agreement & 0 & 0 & 0 & 0 & 0 & 0 & 0 & 0 \\
\hline DOE-HQ & 0 & 0 & 0 & 0 & 0 & 0 & 0 & 0 \\
\hline $\mathrm{FO}$ & 0 & 0 & 0 & 0 & 0 & 0 & 0 & 0 \\
\hline $\mathrm{RL}$ & 0 & 0 & 0 & 0 & 0 & 1 & 0 & 1 \\
\hline Total Project & 0 & 0 & 0 & 0 & 0 & 1 & 0 & \\
\hline
\end{tabular}

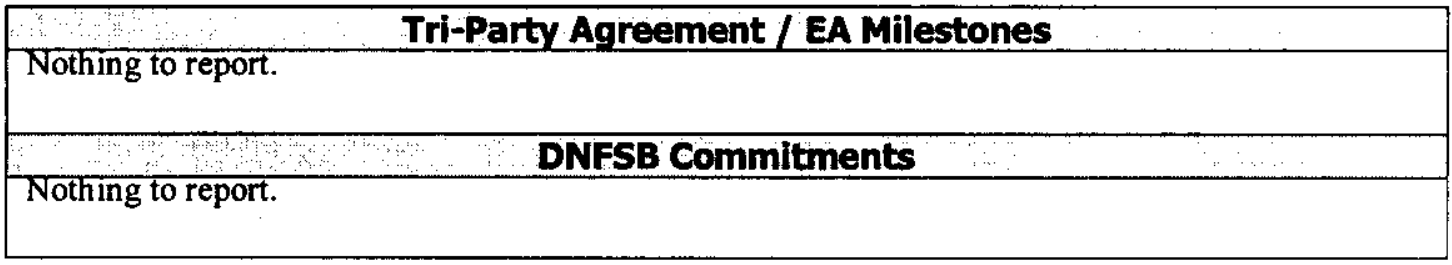

\section{MILESTONe EXCEPTION REPORT}

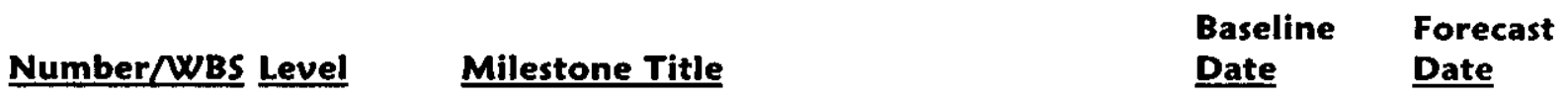

\section{OVERDUe - 0}

FORECAST LATE - 0 


\section{Performance Objectives}

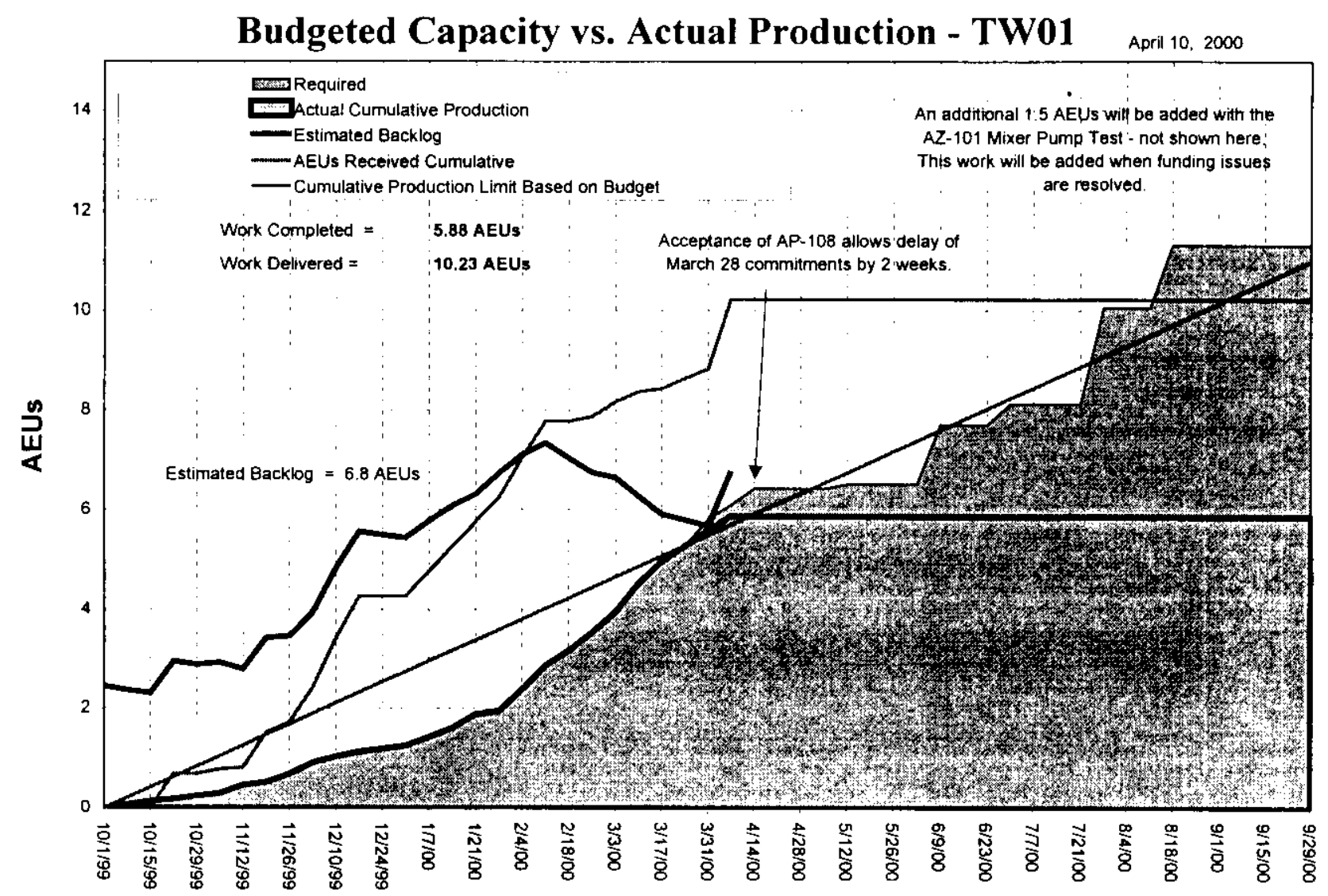

Continue working with RPP on 222-S laboratory production integration. Will Yellow meet September commitment of eleven AEUs. Production through April 21, 2000 is 6.4 AEUs.

\section{KEY INTEGRATION ACTIVITIES}

- Support ORP Privatization Readiness-to-Proceed activities.

- Continue to support BNFL efforts to establish required analytical support for glassification operations.

- In the longer term, BNFL could utilize unused space at WSCF for cold run test support and process laboratory analytical equipment testing.

- The 222-S laboratory, with some refurbishment might become a low cost option to a new large-scale laboratory associated with the glassification facility.

- Continue to support RL with the WSCF path-forward study, which evaluates the spectrum of services WSCF provides versus other potential options.

- $\quad$ Discussion by the Site Management Board is planned in May 2000. 

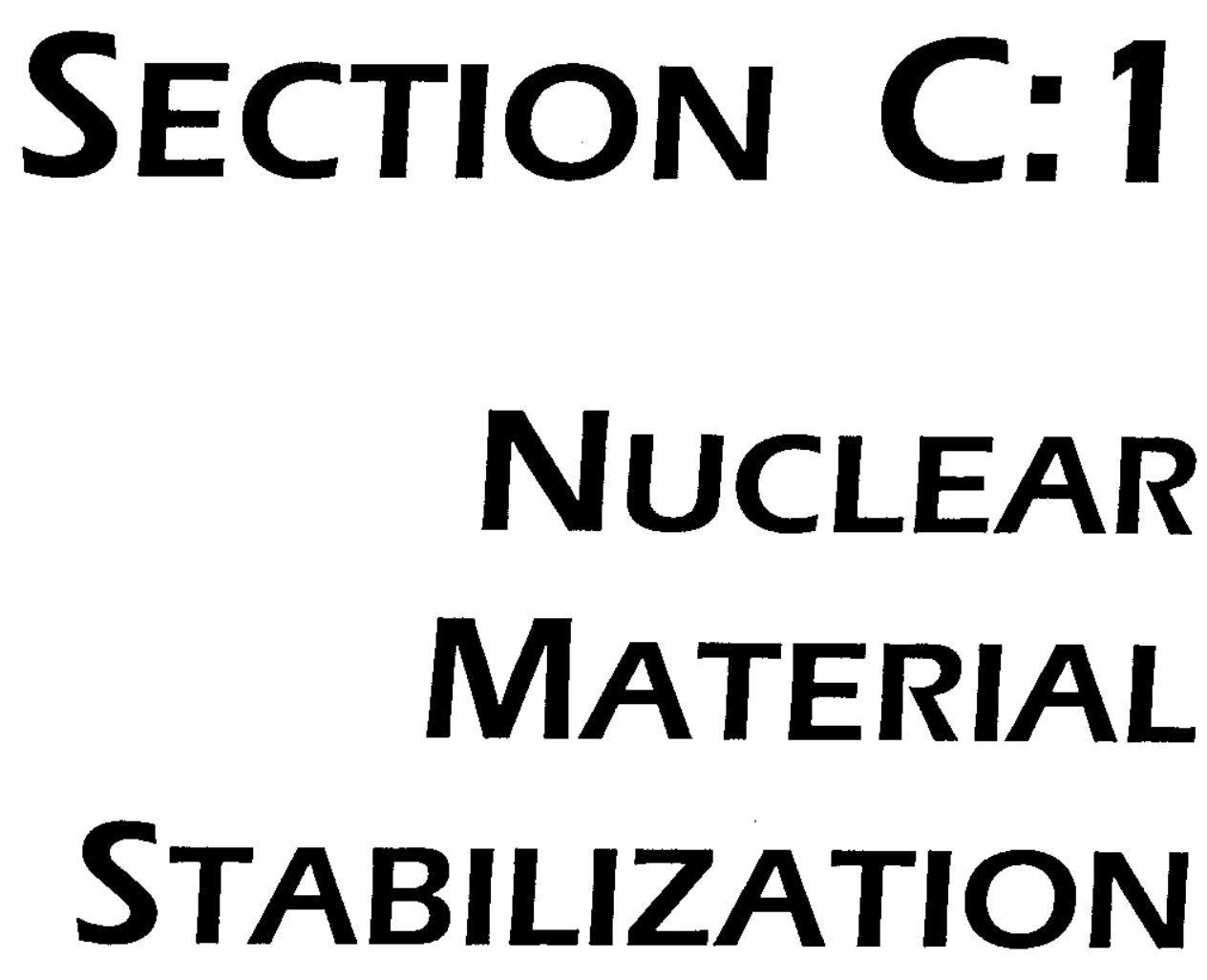

PROJECT MANAGERS

\author{
P. M. Knollmeyer, RL \\ Phone: (509) 376-7435
}

G. W. Jackson, WSMS Phone: (509) 373-6622 


\section{SUMMARY}

The Nuclear Material Stabilization mission consists of the Plutonicm Finishing Plant (PFP), WBS 1.4.5, PBS TP05.

NOTE: Unless otherwise noted, the Safety, Conduct of Operations, Milestone Achievement, and Cost/Schedule data contained herein is as of March 31,2000. All other information is as of April 14,2000 , unless otherwise stated.

As of April 14, 2000, a total of 224 cans of Plutonium oxides and sludges have been stabilized through thermal stabilization (23 items since last report). A total of 13 liters of Plutonium nitrate solution have been stabilized in the prototype vertical denitration calciner [no change since December 1999 due to focus on $\mathrm{Mg}(\mathrm{OH})_{2}$ Precipitation Process installation activities].

The installation of three additional muffle furnaces for thermal stabilization of oxides has been completed. A total of five furnaces are now operational.

Fiscal-year-to-date milestone performance (EA, DOE-HQ, and RL) shows that two of four milestones ( 50 percent) were completed on or ahead of schedule, no milestones were completed late, and two (50 percent) are overdue. Milestone TRP-00-415 is delayed due to comment incorporation before design release. The design is now scheduled for release May 5, 2000. Milestone TRP-00-500 is late due to a proposed change in process implementation. A letter was sent to RL indicating the milestone would not be met. Further details can be found in the milestone exception report following the cost and schedule variance analysis.

\section{ACCOMPLISHMENTS}

\section{Maintain Safe and Compliant PFP}

- As of April 21, 2000, there have been 141 days without a lost workday injury.

- $\quad$ Modified PFP airborne radioactivity area (ARA) posting practice allowing limited area ARA posting to support duct level decontamination without posting the entire processing area as ARA.

- Could provide a cost savings by reducing resources needed for duct level decontamination work.

- $\quad$ Also being reviewed for implementation in other areas.

- Completed the OMEGA Sprinkler Head Replacement Project in the 234-5Z duct level, enabling impairments against Risers \#9 and \#11 to be cleared.

\section{Oxides/Metals/Polycubes Stabilization}

- Completed startup of the three addition muffle furnaces in the HA21I glove box and initiated routine operations two months ahead of schedule. Year-to-date, 224 items have been stabilized.

- $\quad$ Successfully completed preliminary testing of PFP's ability to meet $950^{\circ}$ stabilization criterion. (DOE Standard 3013-99 requires that "oxides shall be stabilized by heating the 
material in an oxidizing atmosphere to a Material Temperature of at least $950^{\circ} \mathrm{C}$ for not less than two hours.").

\section{Maintain Safe \& Secure SNM}

- $\quad$ Proceeded with corrective actions established to support Pu metal vulnerability:

- Initiated enhanced surveillance (weighing/radiography) of 2736-Z metal inventory.

- $\quad$ Developed schedule to support stabilization of high risk items.

- $\quad$ Readiness expected April 28.

\section{Solution Stabilization}

- Continued progress to support startup of Pu Solution Stabilization:

- Glovebox 4 (filtrate) and the support frame for glovebox 3 (process) were received and glovebox 4 has been installed in room $230-\mathrm{C}$.

- $\quad$ Provisionally certified 5 operators on the $\mathrm{Mg}(\mathrm{OH})^{2}$ process during testing at the glovebox vendor: Identified equipment and arrangement problems. Finalized the draft operating procedures.

- Plan of Action for the ORR was issued for final internal review and informal review by RL.

- Download of solutions in room 227 has been completed in support of Phase II testing by Plutonium Processing Support Laboratories (PPSL).

\section{Polycube Stabilization}

- Completed Phase II testing of Polycubes stabilization (isotopics, heavy metals, pyrolysis products, gas generation, heat of reaction and process optimization). A report of the summary test results and the report documenting the operating parameters will be issued by the end of the April.

\section{SAFETY}

Safety performance continued to be excellent in March with no OSHA Recordable or Lost Workday Case injuries.

The DOE Safety Cost Index has both a new average and control limits reflecting the significant decrease noted last month. FY 2000 OSHA case rate and DOE Safety Cost Index are very favorable

OSHA recordable case rate has significantly improved in comparison to the adverse trend of Spring 1999. As of April 21, 2000, there have been 141 days without a lost workday injury. 

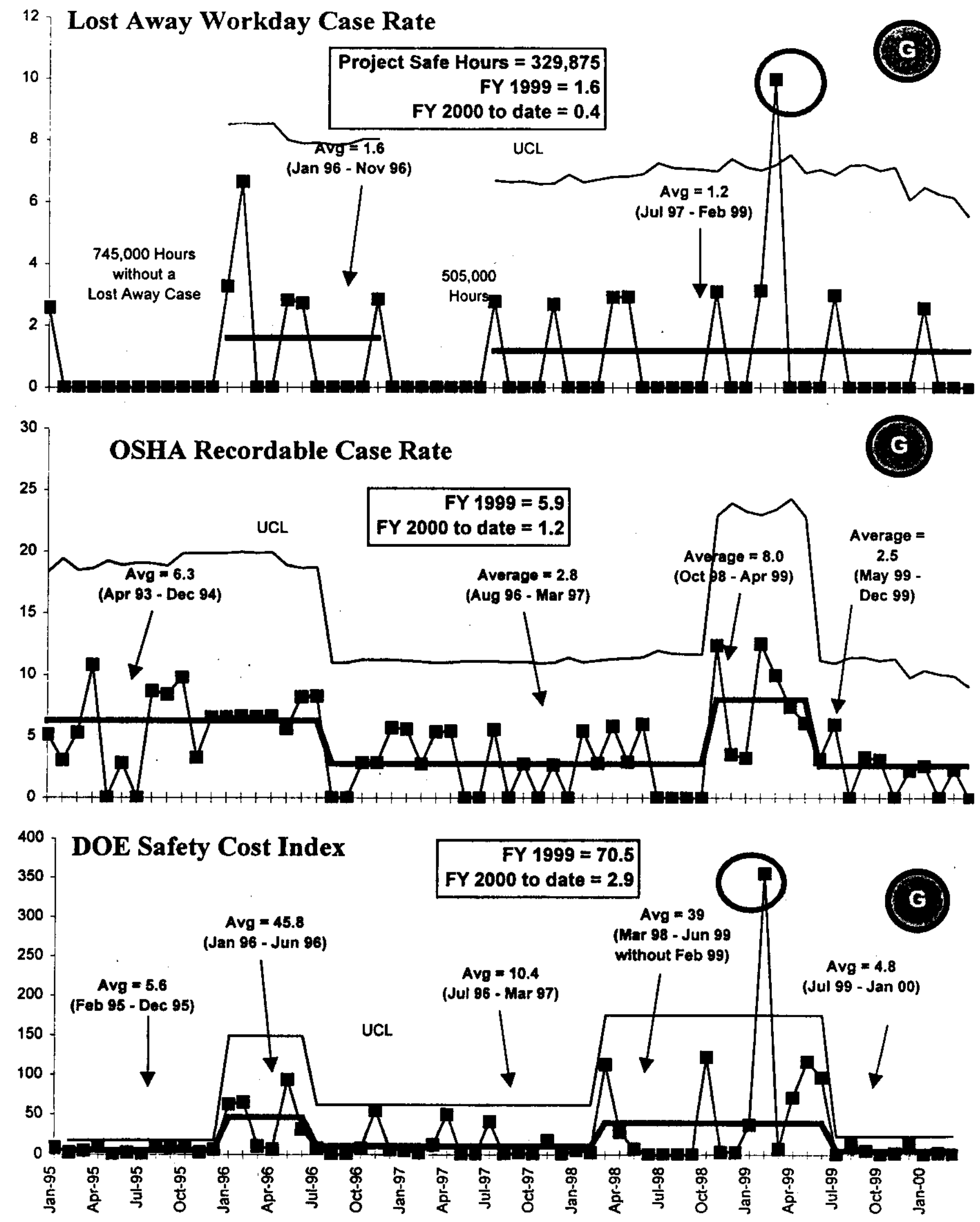


\section{CONDUCT OF OPERATIONS / ISMS STATUS}

CONDUCT OF OPERATIONS

Events per 200,000 Hours

Green
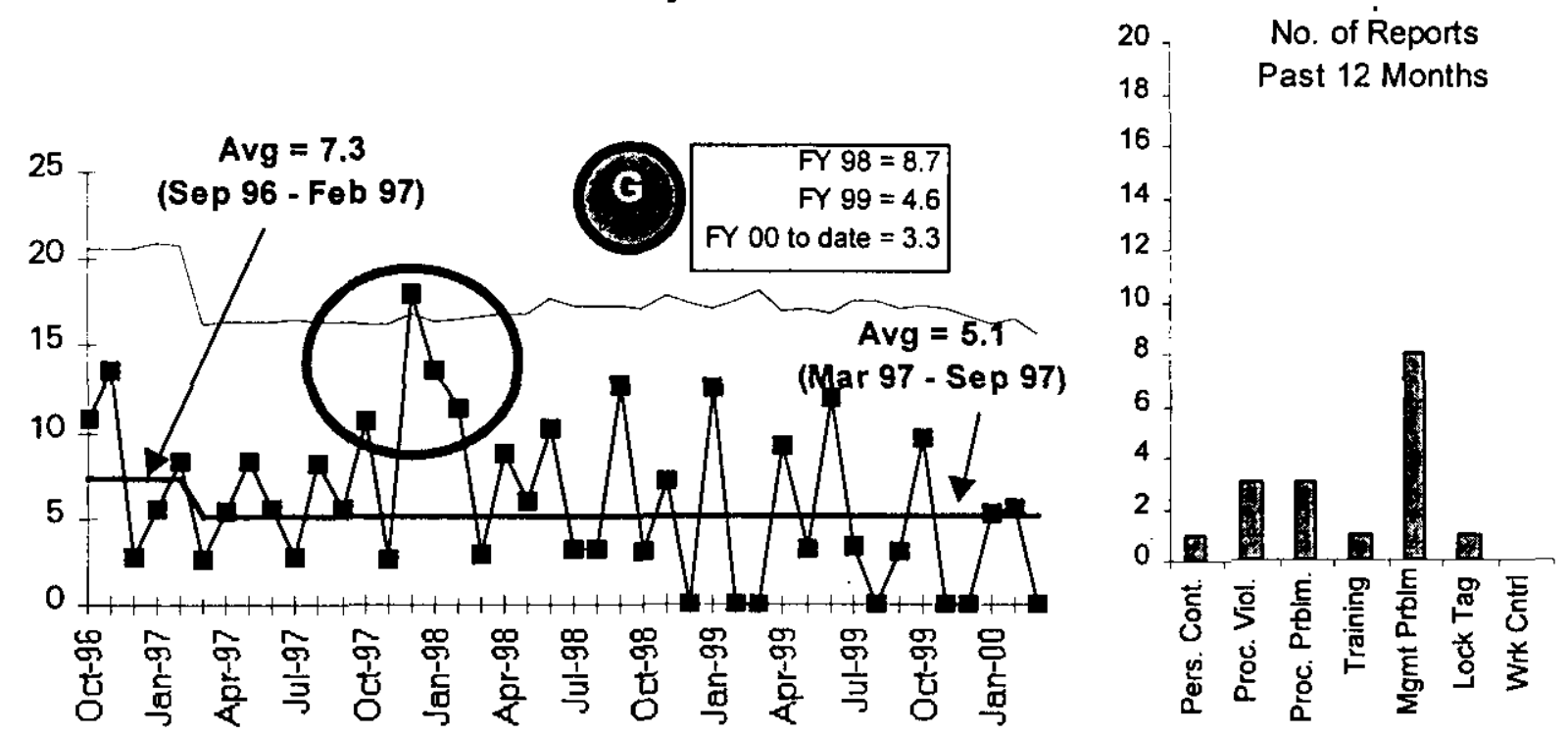

ISMS STATUS

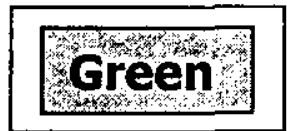

- All action items resulting from the Nuclear Material Stabilization Project Phase 1 verification assessment of the Integrated Safety Management System implementation have been completed.

- $\quad$ Phase II verification will be completed in conjunction with all Fluor projects during the 3 rd quarter of the fiscal year.

\section{BREAKTHROUGHS / OPPORTUNITIES FOR IMPROVEMENT}

\section{BREAKTHROUGHS}

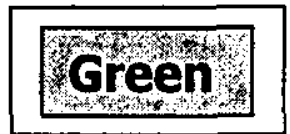

- Implementation of a WIPP "validated" plutonium measuring Nondestructive Assay (NDA) system in FY 2000 is being worked. If successful, implementation of this WIPP "validated" Pu NDA measurement for residues processing will significantly reduce shipment costs to WIPP (i.e., results in significantly fewer drums by as much as 1,000 , which will reduce overall costs by approximately $\$ 2.4 \mathrm{M}$ [i.e., $\$ 2.4 \mathrm{~K}$ per drum]. NDA equipment has been authorized and purchasing is in process. 


\section{OPPORTUNITIES FOR IMPROVEMENT}

- Modification of Personnel Security Assurance Program (PSAP) two-man rule requirements, which would provide a potential reduction of resources for facility surveillance and maintenance activities, is in committee review. A recommendation is expected by May 2000 .

- $\quad$ Modified PFP airborne radioactivity area (ARA) posting practice allowing limited area ARA posting to support duct level decontamination without posting the entire processing area as ARA. This not only provides a current cost savings by reducing resources needed for duct level decontamination work, it is also being reviewed for implementation in other areas.

- Discontinuing routine analysis of stabilized oxides for residual moisture in favor of testing prior to final canning could save staff-hours and radiation dose. An action plan is being developed with a completion schedule for May 2000.

- A new Criticallity Safety Evaluation Report (CSER) allowing additional boats in HC-18BS is under development. This will allow more efficient operations and should accelerate throughput. A rough draft will be available by the end of April.

\section{UPCOMING ACTIVITIES}

- Complete annual revision to Integrated Project Management Plan (IPMP) in May 2000.

- Deliver 2 Validated Data Packages on Tank 241-Z-361 core samples in May 2000.

- Thermally stabilize metals determined to be of higher risk as a result of ongoing surveillance activities (ie: radiography and weighing) in May 2000.

- $\quad$ Begin Pu solution stabilization via $\mathrm{Mg}(\mathrm{OH})_{2}$ in the fourth quarter of FY 2000.

- Deliver remaining glove boxes and equipment for installation in April 2000.

- Complete installation in July 2000.

- Complete ORR and training activities for stabilization activities in room 230-C in September 2000 .

- $\quad$ Startup Cementation operations in fourth quarter of FY 2000.

- Complete installation and startup of the Bagless Transfer System (BTS) in fourth quarter of FY 2000.

- Begin metal stabilization processing in November 2000.

- Initiate polycube stabilization in 1st quarter of FY 2001. 
- Complete Vulnerability Assessment that will be used to determine process location and storage location of Pipe-n-Go drums in May 2000.

- Complete RL Milestone FSP-00-415, Complete Project W-460 Facility Design, (now overdue) by incorporating comments to prepare design for release for construction by third quarter 2000 .

\section{Cost Performance $(-\$ 0.5 \mathrm{M})$ :}

\begin{tabular}{|l|c|c|c|}
\hline & BCWP & ACWP & VARIANCE \\
\hline Nuclear Material Stabilization & $\$ 54.0$ & $\$ 54.5$ & $-\$ 0.5$ \\
\hline
\end{tabular}

The $\$ 0.5$ million (one percent) unfavorable cost variance is within established thresholds. Some underruns in the cost variance due to a shortage of staff and lag in costs for contracts [e.g., including the Energy Services contract for steam, $\mathrm{Mg}(\mathrm{OH})_{2}$ glove box procurements, etc.] are being offset by the increased assessment for fee and analysis costs for the Tank 241-Z-361 samples.

\section{SChedule Performance ( $\$ \mathbf{\$ 1} .8 \mathrm{M})$ :}

\begin{tabular}{|l|c|c|c|}
\hline & BCWP & BCWS & VARIANCE \\
\hline Facility Stabilization & $\$ 54.0$ & $\$ 65.7$ & $-\$ 11.8$ \\
\hline
\end{tabular}

The $\$ 11.8$ million (18 percent) unfavorable schedule variance is due primarily to the behind status on Project W-460 capital activities, such as the elimination of trailers and vault modification design; infrastructure projects, such as criticality alarm panel and radiation constant air monitor upgrades; and the solution stabilization and cementation startup activities. The project is significantly ahead of schedule on oxide stabilization. 


\section{Fy 2000 Cost/Schedule Performance - All Fund Types Cumulative to Date Status - (\$000)}

WBS

\begin{tabular}{lllllllll}
\multicolumn{9}{c}{ FYTD } \\
\cline { 2 - 5 } By PBS & BCWS & BCWP & ACWP & SV & $\%$ & CV & $\%$ & PEM
\end{tabular}

1.4.5 PFP

TP05 Deactivation $\$ 65,706 \quad \$ 53,950 \quad \$ 54,477 \quad \$(11,755)-18 \% \quad \$(526)-1 \% \quad \$ 127,203$

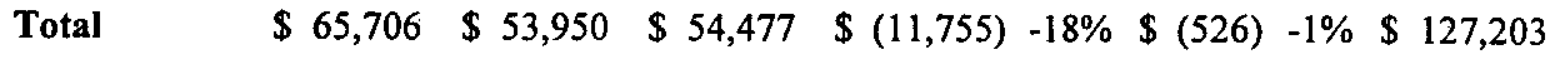

RL-Directed costs (steam) are included in the PEM BCWS.

\section{Cost/Schedule Performance Indices (MARCH 2000 AND FYTD)}

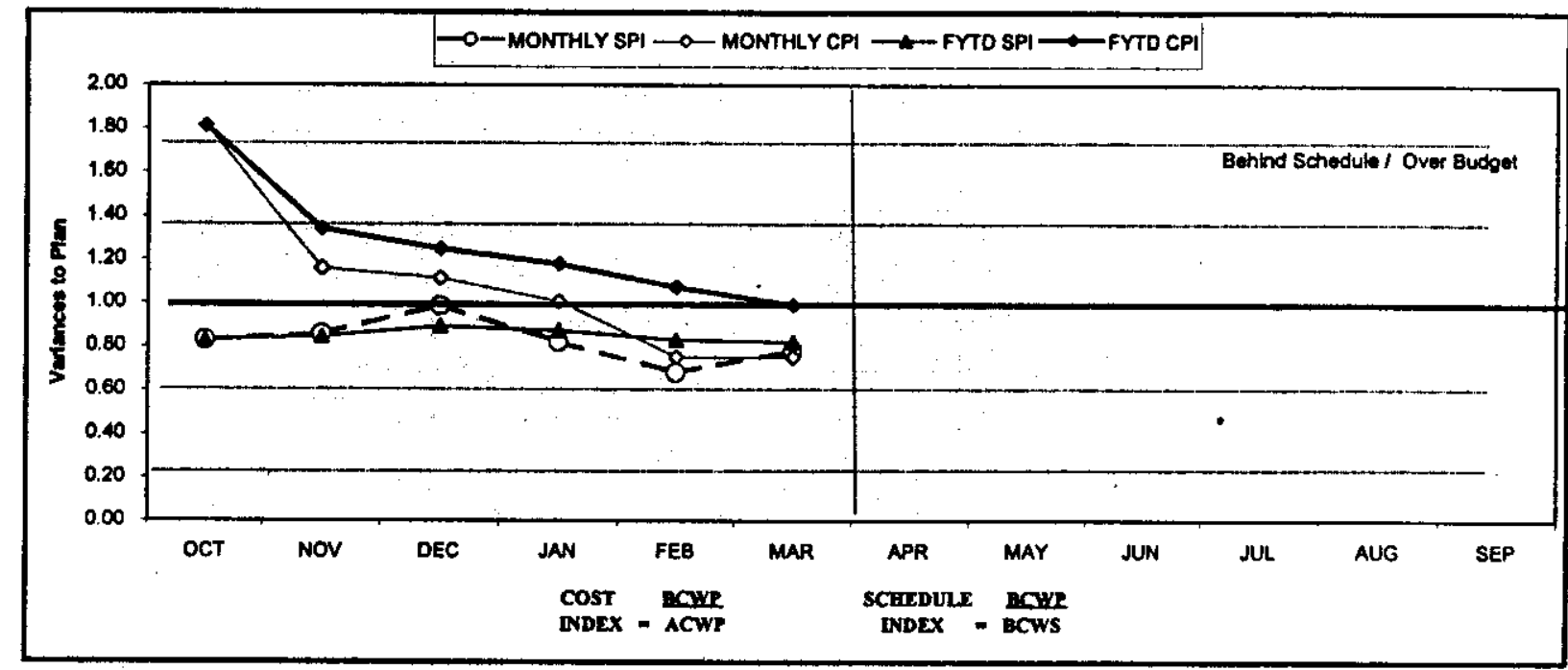

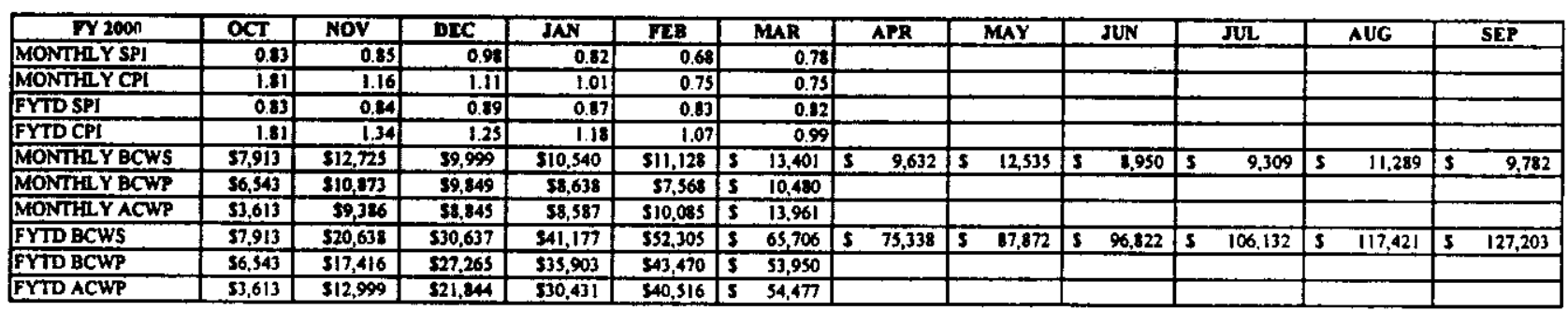




\section{COST VARIANCE ANALYSIS: $(-\$ 0.5 \mathrm{M})$}

\section{WBS/PBS}

\subsection{0/TP05}

\section{Title}

Description and Cause: Underrun due to lag in subcontractor (PTH) invoices and accruals for Safeguards and Security (SAS) contracts.

Impact: No impact.

Corrective Action: None required.

\subsection{4/TP05 Disposition of Nuclear Materials $(+\$ 1.6 \mathrm{M})$}

Description and Cause: Positive cost variance is the result of the ability to disposition waste and product materials at significantly reduced costs. There is a partially offsetting negative cost variance associated with Project W-460 because of delays in starting construction.

Impact: Project W-460 could cost more than originally estimated.

Corrective Action: Maintain aggressive hiring, training, and clearance program for Nuclear Operators and other support, which is now being implemented as planned.

\subsection{5/TP05 Transition PFP (-S0.6M)}

Description and Cause: The unfavorable cost variance is the result of increased costs for lab analysis of tank 361 samples as well as carryover work scope not yet reflected in the baseline. Laboratory Analysis has shown tank values exceed 50 ppm of PCBs. Evaluation as to disposition is underway.

Impact: If work scope is stopped due to budget issues, the Tri-Party Agreement milestone due May 31, 2000 would not be met. Continuing work scope will result in cost over run for this activity, savings from elsewhere within NMSP will be required to offset the overrun. Corrective Action: Approve and implement baseline change request to reflect FY 1999 carryover work scope. If PCBs are found to exceed allowable limits, a separate change request may be required to incorporate the additional special waste handling requirements into the baseline. Identify cost savings from elsewhere within the NMSP to offset this overrun.

\subsection{2/TP05 PFP Fee Allocation (-\$2.5M)}

Description and Cause: Unfavorable cost variance due to point adjustment $(-\$ 1,769 \mathrm{~K})$ in October to adjust for delay in staff hiring ramp-up at the beginning of FY 2000. Also an increase in the fee accrual from a rate of $90 \%$ to $100 \%$.

Impact: No impact.

Corrective Action: None required. 


\section{SCHEDULE VARIANCE ANALYSIS: (-\$11.8M)}

\section{WBS/PBS}

\subsection{4/TP05}

Description and Item Project W-460, Plutonium Stabilization and Packaging System, definitive design and construction. Facility construction modifications have not yet started as scheduled, due to deviations to the Definitive Design, required changes to the NEPA Supplement Analysis and approval of the Notice of Construction (NOC) by the Washington State Department of Health (WSDOH).

Impact: Potential delay in the startup of the Bagless Transfer and Stabilization system in 2736-ZB, which can impact stabilization activities in FY 2001.

Corrective Action: To assist in the recovery, a second BTS unit is being installed in the 234-5Z facility, which will enable BTS unit operation in FY 2000 as originally planned. Project W-460 management and WSDOH staffs are aggressively working to approve the NOC, which will enable construction to begin. The aggressive hiring, training and clearance program for Nuclear Operators and other support staff is being implemented as planned.

\subsection{3/TP05 Stabilize SNM (-\$3.1M)}

Description and Cause: The unfavorable schedule variance is due primarily to the behind schedule status on residues and solution stabilization activities. Solution stabilization construction activities are two months behind schedule, with startup now planned for September 2000. Also, restart activities for cementation are behind schedule due to the need for additional Nondestructive Assay (NDA) equipment necessary for WIPP validation. Restart of cementation is now anticipated in late July 2000 , versus the April 2000 restart. Oxide stabilization activities continue significantly ahead of schedule.

Impact: Potential delay in both restart of cementation and startup of $\mathrm{Mg}(\mathrm{OH})_{2}$ precipitation processing for solution stabilization; anticipate schedule recovery by the end of FY2000.

Corrective Action: An aggressive recovery plan has been developed for both solution stabilization and cementation activities to commence operations in September and July respectively. Plans are also in place to stabilize solutions and residues exceeding baseline commitments even with a late processing start. NDA equipment has been ordered and NMSP is working with the WM Project to meet the WIPP certification.

\section{ISSUES}

DOE Standard 3013-99 requires that "oxides shall be stabilized by heating the material in an oxidizing atmosphere to a Material Temperature of at least $950^{\circ} \mathrm{C}$... for not less than 2 hours."

Impact(s): This issue is resolved.

Corrective Action: A test plan was executed to evaluate the process options. Two tests with a surrogate oxide material in the spare thermal stabilization furnace indicate that the oxide powder temperature exceeds the minimum stabilization temperature of $950^{\circ} \mathrm{C}$ before the furnace reaches its steady-state control temperature of $1000^{\circ} \mathrm{C}$. The surrogate oxide remained above $950^{\circ} \mathrm{C}$ for at least $1 / 2$ hour before the furnace reached that 
temperature, throughout the 2 hours with the furnace at $1000^{\circ} \mathrm{C}$, and at least 0.1 hour after the furnace began to cool from $1000^{\circ} \mathrm{C}$.

Lack of certified shipping containers in the DOE Complex to meet PFP schedules. Impact(s): Prohibits shipment of nuclear materials that cannot go to either WIPP or DOT-6M containers (i.e., Pu standards for re-certification, shipment of reactive materials for processing elsewhere, etc.).

Corrective Action: Work with the DOE Complex to certify containers to meet PFP shipping needs (i.e., 9975 container to be re-certified in June 2000, etc.).

Jointly resolve issues associated with precipitation process. Concentration, Density, Filtrate Handling (permitting of $241-Z$ to handle heavy metals), discard directly to tank farms.

Impact(s): Concentration/density issue may significantly impact the number of containers to be stored under final disposition. The $241-\mathrm{Z}$ permitting issue, if not resolved, can impact the plant's ability to discard solution waste to tank farms resulting from the $\mathrm{Mg}(\mathrm{OH}) 2$ precipitation processing of plutonium solutions.

Corrective Action: Concentration/density issue is being worked through laboratory testing at both PNNL and PFP's Plutonium Process Support Laboratories. Appropriate actions will be taken according to laboratory results. Also, project management has worked with the Tank D-5/D-8 readiness team to ensure that these tanks are ready to support solution stabilization processing startup as scheduled.

Implementation of supercritical fluid extraction technology for moisture measurements will require installation of a new glovebox in room 235-B.

Impact(s): This installation will require several hundred thousand dollars more than budgeted for procurement and installation and result in several weeks of processing impact during the installation.

Corrective Action: Establish a cost and schedule estimate for the installation of this equipment and process a BCR to modify schedule. Problem being worked; last report on this issue.

Equipment for processing $\mathrm{Pu}$ inside the $\mathrm{Mg}(\mathrm{OH})_{2}$ gloveboxes needs to be defined and approved by $O$ perations before glovebox size can be finalized.

Impact(s): Gloveboxes cannot be ordered until size is finalized.

Corrective Action: Use mockup and daily meetings with Operations to finalize the internal arrangement of the gloveboxes to the point where a size can be determined and the gloveboxes ordered.

Seismic concerns related to the material storage cage in room 638 cage, 2736-ZB facility. Impact(s): Completing recovery plan to address these issues, resulting in higher exposure than normal to vault operators.

Corrective Action: Material movement out of cage completed. Statement of work issued to Fluor Federal Services (FFS) to install new seismically qualified racks in room 638 cage. This issue is considered resolved and no longer reported. 


\section{DOE/REGULATOR/EXTERNAL ISSUES}

- $\quad$ RCRA Permitting Part A revisic: for adding ignitability waste code was submitted to Ecology in support of Cementation startup.

- RCRA Permitting in support of Pipe-N-Go:

- A revised Notice of Intent (NOI) to define storage locations at PFP was released for public review

- $\quad$ Revised Part A to provide permitted storage at PFP will be transmitted to Ecology in May 2000

- $\quad$ Notice of Construction (NOC) was sent to Washington State Department of Health (WSDOH) on March 6,2000, could take up to 60 days for approval. No feedback received to-date.

Baseline Change Requests Currentiy in Process

$(\$ 000)$

\begin{tabular}{|c|c|c|c|c|c|c|c|c|c|}
\hline $\begin{array}{l}\text { PRONECT } \\
\text { CHANGE } \\
\text { NUMBER } \\
\end{array}$ & $\begin{array}{c}\text { DATE } \\
\text { ORIGIN. }\end{array}$ & BCR TITLE & $\begin{array}{c}\text { FYoo } \\
\text { COST } \\
\text { MPACT } \\
\$ 000 \\
\end{array}$ & SCH & TECH & $\begin{array}{c}\text { DATE TO } \\
\text { CCB }\end{array}$ & $\begin{array}{c}\text { CCB } \\
\text { APR'VD }\end{array}$ & $\begin{array}{c}R L \\
\text { APR'VD }\end{array}$ & $\begin{array}{l}\text { CURRENT } \\
\text { STATUS } \\
\end{array}$ \\
\hline FSP-2000-001 & $13-$ Oct-99 & $\begin{array}{l}\text { Delete TRP-99-419, Complete } \\
\text { Install. of Production Scale Vertical } \\
\text { Calciner }\end{array}$ & \$o & & & & & & Deleted \\
\hline FSP-2000-004 & 23-Nov-99 & $\begin{array}{l}\text { PFP Test Polycube Stabilization via } \\
\text { Muffle Furnace }\end{array}$ & $\$ 0$ & $\mathbf{x}$ & $\mathbf{X}$ & $17-\mathrm{Feb}-00$ & $17-F e b-00$ & & RL approved \\
\hline FSP-2000-005 & 30-Nov-99 & $\begin{array}{l}\text { Implement PFP Int Proj Mgmt Plan } \\
\text { Addendum 1 }\end{array}$ & $\$ 659$ & $\mathbf{x}$ & $\mathbf{x}$ & & & & In work at PFP \\
\hline FSP-2000-011 & 27-Dec-99 & $\begin{array}{l}\text { Adjusted PFP Cementation } \\
\text { Processing to include Sand, Slag and } \\
\text { Crucible }\end{array}$ & so & $\mathbf{X}$ & $\mathbf{X}$ & 14-Jan- 00 & 18-Jan-00 & $17-\mathrm{Feb}-00$ & Implemented \\
\hline FSP-2000-025 & $10-\mathrm{Mar}-00$ & PFP Replacement Transformer & $\$ 992$ & $\mathbf{x}$ & & 27-Mar-00 & 27-Mar-00 & Not Req'd & Implemented \\
\hline FSP-2000-029 & 26-Jan-00 & PFP FY2000 Funds Reduction & $(\$ 6,885)$ & $\mathbf{X}$ & & 9-Mar-00 & 23-Mar-00 & & $\begin{array}{l}\text { Submitted to } \\
\text { RL 3/24/2000 }\end{array}$ \\
\hline FSP-2000-032 & 22-Mar-00 & PFP 2nd Bagless Transfer System & $\$ 2,127$ & $\mathbf{x}$ & $\mathbf{x}$ & 29-Mar-00 & 7-Apr-00 & & $\begin{array}{l}\text { Submitted to } \\
\text { RL 4/7/2000 }\end{array}$ \\
\hline FSP-2000-035 & 3-Apr-00 & PFP Carry-over Workscope & $\$ 620$ & $\mathbf{X}$ & $\mathbf{X}$ & & & & In work at PFP \\
\hline \multicolumn{10}{|c|}{ ADVANCE WORK AUTHORZATIONS } \\
\hline AWA-00-001 & 21-Oct-99 & Polycube Stabilization Testing & $\$ 500$ & $\mathbf{X}$ & $\mathbf{X}$ & & & 21-Oct-99 & Completed \\
\hline AWA-00-002 & 22-Sep-99 & Residue Cementation & $\$ 500$ & $\mathbf{x}$ & $\bar{x}$ & & & 19.Oct-99 & Completed \\
\hline AWA-00-003 & 01-Jan-00 & Main Power Transformers & $\$ 350$ & $\bar{x}$ & & & & 31-Jan-00 & Completed \\
\hline AWA-00-004 & $01-\operatorname{Jan}-00$ & 2nd Bagless Transfer Unit & $\$ 500$ & $\mathbf{x}$ & $\mathbf{x}$ & & & 11-Feb-00 & Completed \\
\hline AWA-00-005 & 6-Mar-00 & 2nd Bagless Transfer Unit & $\$ 500$ & $\mathrm{x}$ & $\mathrm{x}$ & & & $8-\mathrm{Mar}-00$ & Completed \\
\hline
\end{tabular}


Milestone ACHieVement

\begin{tabular}{|r|r|r|r|r|r|r|r|r|}
\hline & \multicolumn{4}{|c|}{ FISCAL YEAR-TO-DATE } & \multicolumn{3}{c|}{ REMAINING SCHEDULED } & \\
\cline { 2 - 8 } MILESTONE TYPE & $\begin{array}{c}\text { Completed } \\
\text { Early }\end{array}$ & $\begin{array}{c}\text { Completed } \\
\text { On } \\
\text { Schedule }\end{array}$ & $\begin{array}{c}\text { Completed } \\
\text { Late }\end{array}$ & Overdue & $\begin{array}{c}\text { Forecast } \\
\text { Early }\end{array}$ & $\begin{array}{c}\text { Forecast } \\
\text { On } \\
\text { Schedule }\end{array}$ & $\begin{array}{c}\text { Forecast } \\
\text { Late }\end{array}$ & TOTAL \\
FY 2000 \\
\hline Enforceable Agreement & 1 & 0 & 0 & 0 & 0 & 1 & 0 & 2 \\
\hline DOE-HQ & 0 & 0 & 0 & 1 & 0 & 0 & 0 & 1 \\
\hline RL & 1 & 0 & 0 & 1 & 0 & 9 & 0 & 11 \\
\hline Total Project & 2 & 0 & 0 & 2 & 0 & 10 & 0 & 14 \\
\hline
\end{tabular}

\section{Tri-Party Agreement / EA Milestones}

Tri-Party Agreement Milestone M-15-37A (TRP-00-501), "Deliver Two (2)

Tank Z-361 Core Samples to 222-S", due 10/30/99

- $\quad$ Completed 1 month early $(9 / 28 / 99)$

Tri-Party Agreement Milestone (TRP-00-511), "Deliver Two (2) Validated Data Packages to EPA", due 5/31/00

- On Schedule

\section{DNFSB Commitments}

DNFSB Milestone IP-113 (TRP-00-500), "Install 2 LANL Pyrolysis Units for Stabilization of Polycubes at PFP", due $12 / 31 / 99$

- Alternative path forward using PFP muffle furnaces being evaluated. Thermal stabilization testing at PNNL and PFP's PPSL underway consistent with approved AWA. Issued path forward recommendation to use direct thermal stabilization process versus pyrolysis.

Letter issued to DOE-RL indicating milestone would not be met.

\section{MILESTONE EXCEPTION REPORT}

\begin{tabular}{|c|c|}
\hline & ritlo \\
\hline
\end{tabular}

\section{OVERDUe - 2}

TRP-00-415 HQ Complete Project W-460 Facility Design $\quad 02 / 29 / 00 \quad 05 / 05 / 00$

\subsection{5}

Cause: Issuing for review took longer than scheduled and then received more comments back than anticipated, thus comment incorporation taking longer than planned.

Corrective Action: Incorporating comments to ready design for release for construction. 
TRP-00-500 HQ

1.4.5
Install Two LANL Pyrolysis Units for Stabilization o' Polycubes
$12 / 31 / 99$

Proposed

Deletion

Cause: See DNFSB Commitment above

Corrective Action: A BCR to remove pyrolysis stabilization of polycubes and implement thermal stabilization in its stead has been approved by $\mathrm{RL}$ and implemented into the baseline. However, this is a HQ milestone and cannot be removed from the list.

\section{FY 1999 OVERDUE - 2}

\section{TRP-99-419 RL Complete Installation of Production 09/30/99 Proposed 1.4.5 Scale Vertical Calciner Deletion}

Cause: The production scale vertical calciner has been replaced with the Magnesium Hydroxide Precipitation process.

Impact: No impact. This milestone is obsolete.

Corrective Action: Since installation and testing of the production scale vertical calciner is an EM-65 Management Commitment, the Department of Energy, Richland Office (DOE-RL) change control process cannot remove this milestone.
TRP-99-500 HQ
Complete Installation \& Testing of
09/30/99 Proposed
1.4.5
Production Vertical Calciner
Deletion

Cause: The production scale vertical calciner has been replaced with the Magnesium Hydroxide Precipitation process.

Impact: No impact. This milestone is obsolete.

Corrective Action: Since this milestone is a DOE-HQ milestone and is part of the DOE-HQ 1998 DNFSB Recommendation 94-1 Implementation Plan, the Department of Energy, Richland Office change control process cannot remove this milestone. However, this milestone will be removed upon approval of the revised DOE-HQ DNFSB Recommendation 94-1 Implementation Plan. 


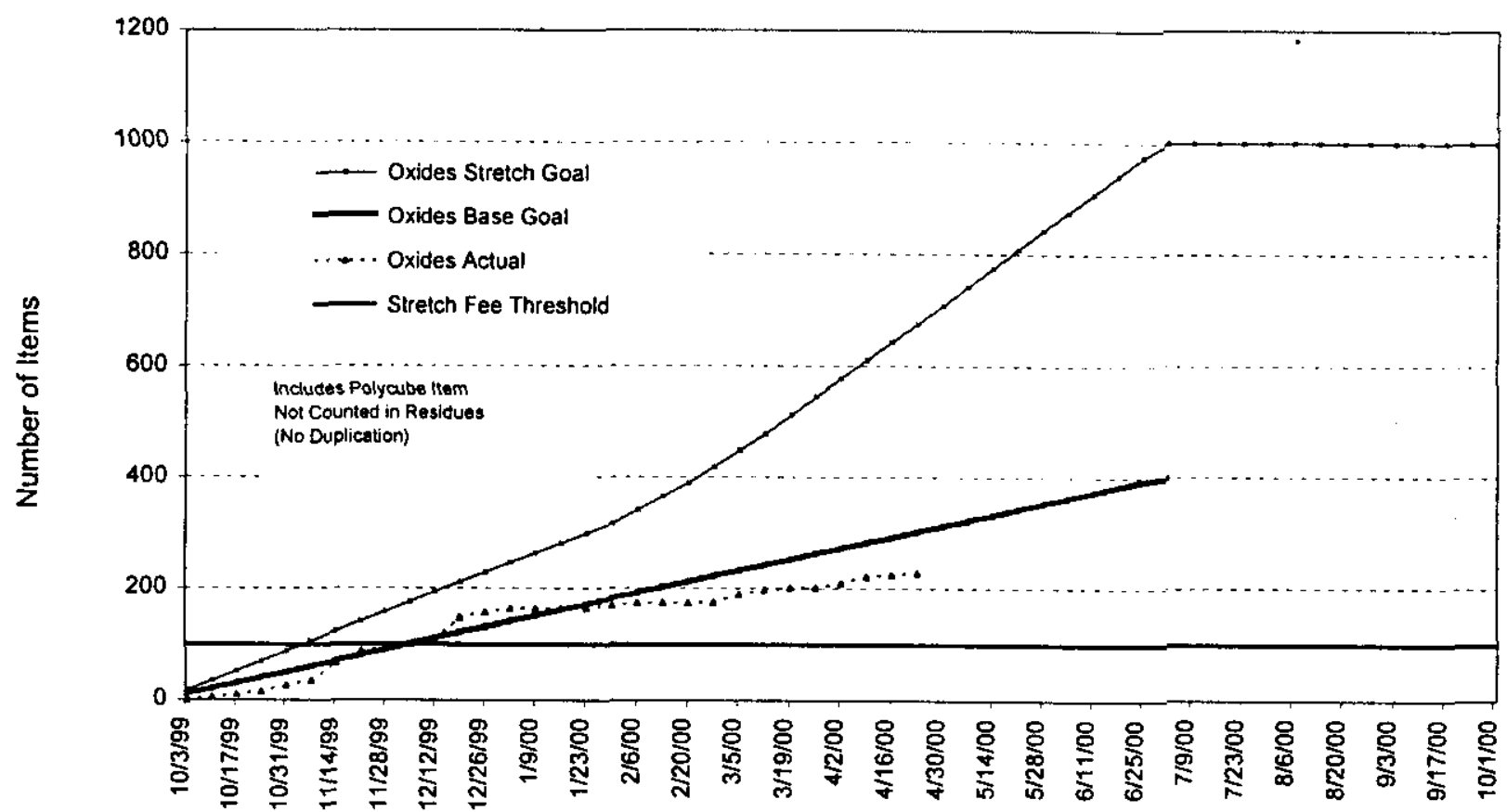

\begin{tabular}{|c|c|c|c|c|c|c|c|c|c|c|c|c|c|c|c|c|c|c|c|c|c|c|c|c|c|c|c|c|}
\hline & & & & & & $12 / 3$ & $12 / 10$ & $1 / 2$ & 20 & 1/30 & $2 / 13$ & 2227 & $3 / 12$ & 3281 & 40 & $4 / 16$ & $4 / 30$ & $3 / 14$ & $5 / 28$ & QVis? & $7 / 25$ & 70 & $7 / 23$ & 20 & $\theta / 3$ & & To10 & \\
\hline & 10 & 53 & 88 & 123 & 158 & 178 & $\overline{212}$ & 2 & 262 & 318 & 360 & 20 & 678 & 15 & $B 11$ & s+4 & $10 !$ & 1778 & $\infty \times 2$ & 8 & 1 & 1000 & $\infty$ & 1000 & 1000 & $\infty$ & ) & \\
\hline Dxde & 11 & \begin{tabular}{|l|l|}
30.2 \\
\end{tabular} & 4 & 70.8 & .7 & 10 & 121.0 & $i$ & 1161.3 & 11 & 201.6 & 8 & 241.0 & $\mid 202.12$ & 282.2 & 202.3 & 31 & 332.63 & 332.8 & 373.0 & 33 & & & & & & & \\
\hline & & 10 & 2 & 67 & 8 & 10 & 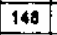 & 164 & $t$ & 18 & 174 & 11 & 197 & 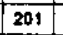 & 11 & 2 & & & & & & & & & & & & \\
\hline olet & 100 & 100 & 100 & 100 & 100 & 100 & 100 & 20 & 100 & 100 & 100 & 100 & 10 & . & 100 & 100 & 100 & 100 & & 100 & 100 & 100 & 100 & 100 & 100 & $\infty 0$ & $\infty$ & $\infty$ \\
\hline
\end{tabular}

\section{SOLUTION STABILIZATION}

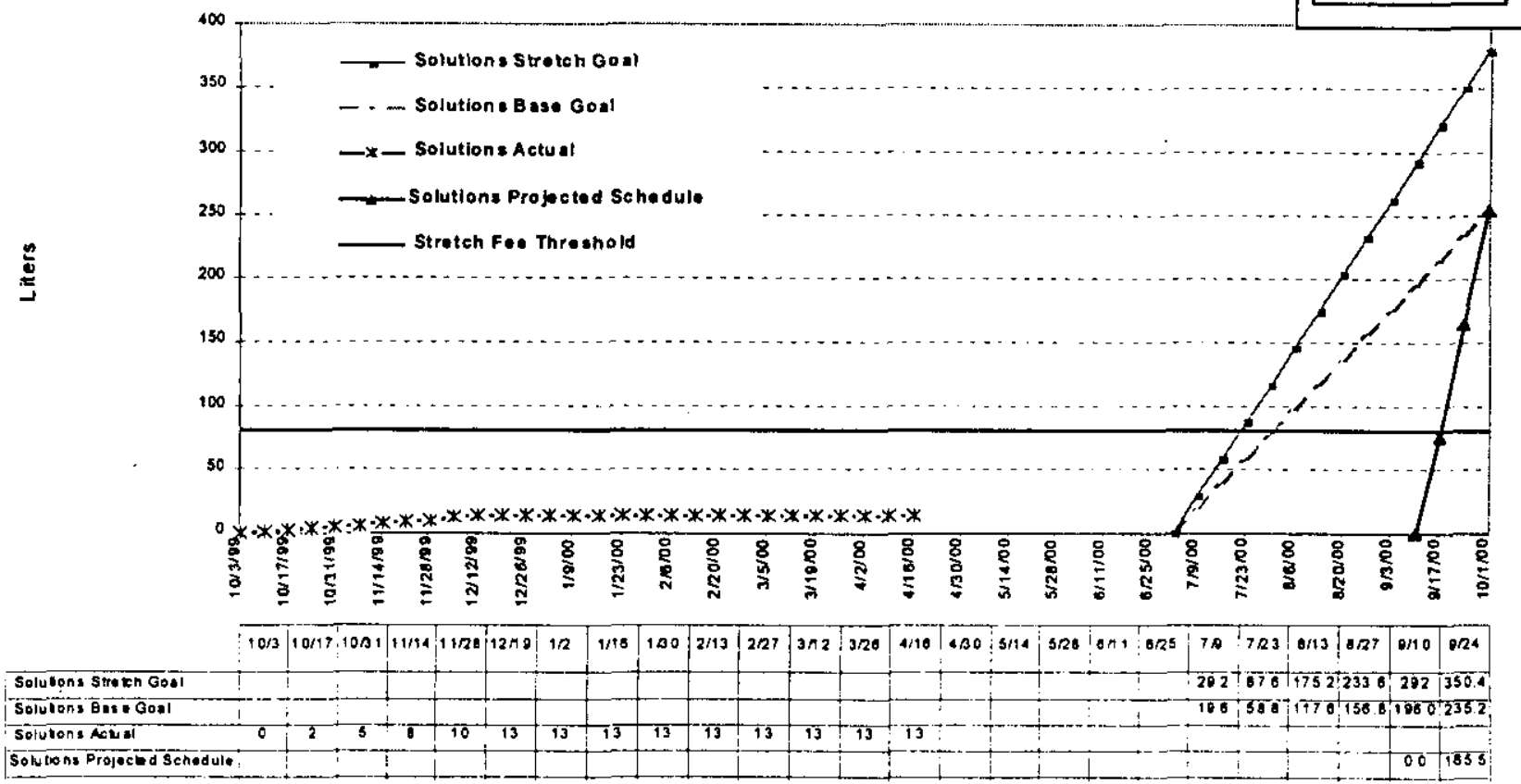

Aggressively pursuing construction completion in support of stabilization activities. 


\section{RESIDUES STABILIZATION}

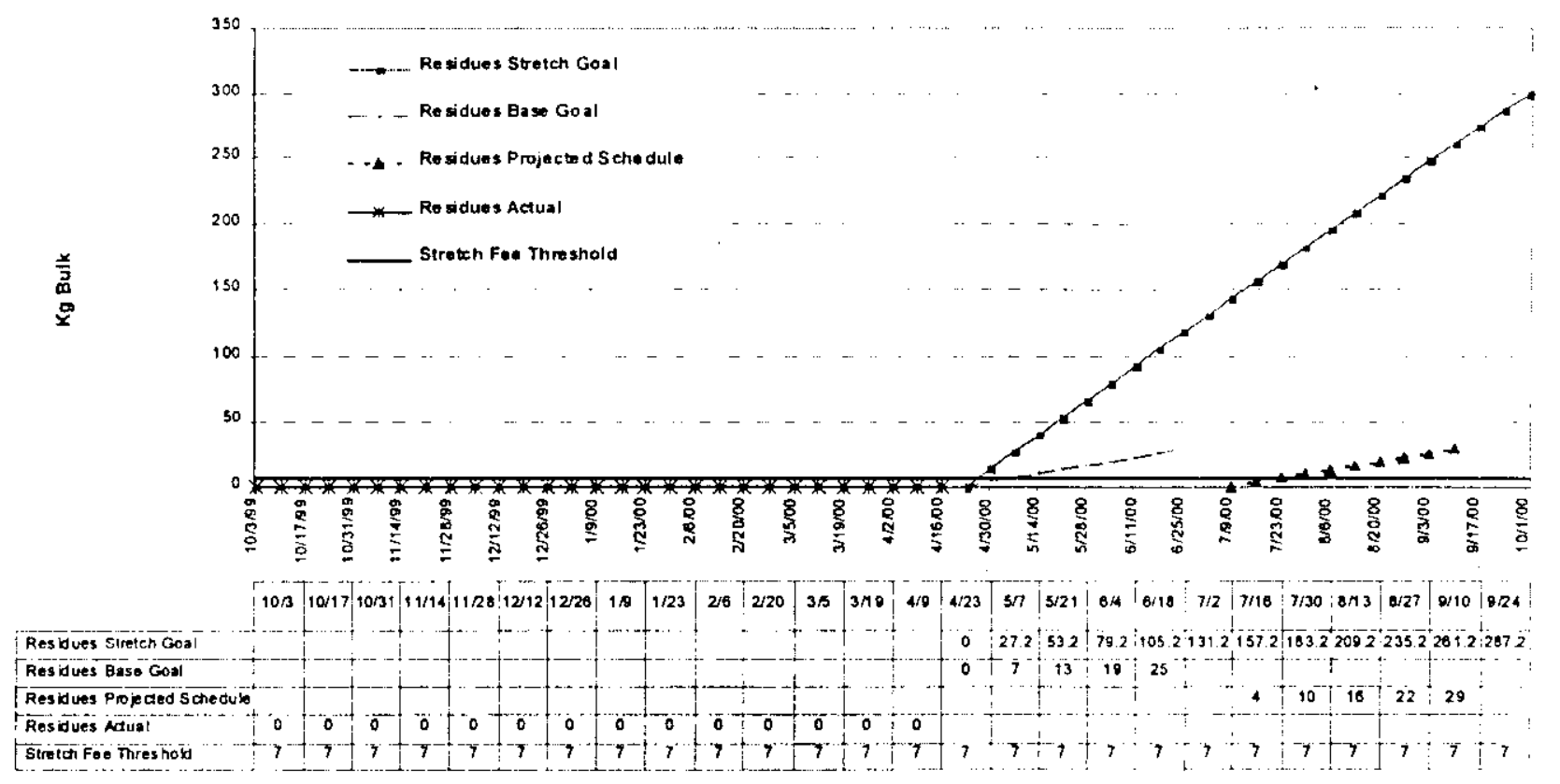

Update baseline schedule for new cementation start-up date and adjust ash schedule for preparatory work.

\section{KEY INTEGRATION ACTIVITIES}

- An internal workshop was held to start development of Data Quality Objectives (DQOs) for stabilized material sampling and analysis. This work is being led by PNNL.

- Work continues with Rocky Flats to come to a joint solution to PFP's stabilization heating process.

- $\quad$ There is a Memorandum of Understanding (MOU) with Waste Management to define requirements and responsibilities to support Central Waste Complex (CWC) and Waste Isolation Pilot Plant (WIPP).

- $\quad$ Phase I testing with surrogate solutions by PNNL continues.

- Continue work with Rocky Flats to procure containers (Pipe-n-Go) to support PFP Residue Stabilization without the need for another procurement action.

- Technical assessments by PNNL of various path forward decisions continue. 


\section{Nuclear Materials Stabilized During the Current Period}

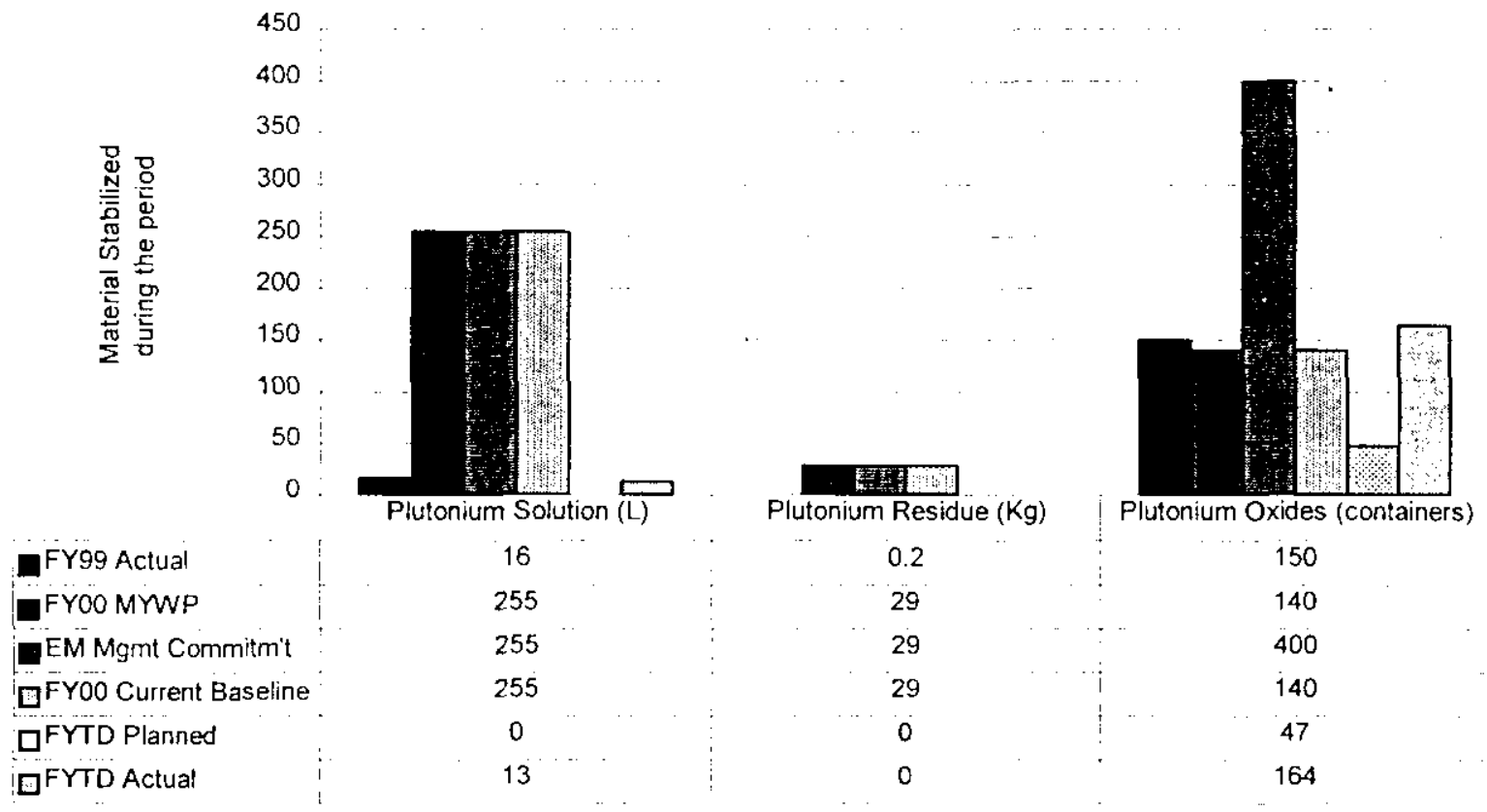

Plutonium Solution: It is expected that the current FY00 baseline will be met. Laboratory testing resulted in early stabilization of 13 liters of Plutonium solution during 1st quarter FY00.

Plutonium Oxides: Approval of Environmental Impact Statement via supplement analysis increasing charge size of furnaces by a factor of 4 and increasing number of furnaces from 2 to 5 allowed the actual stabilization to proceed faster than planned. Metal/oxide stabilization will continue for the next quarter, whereupon the focus will switch towards stabilization of the solutions.

Uranium in Other Forms: There is no Uranium inventory. 


\section{Building Deactivation}

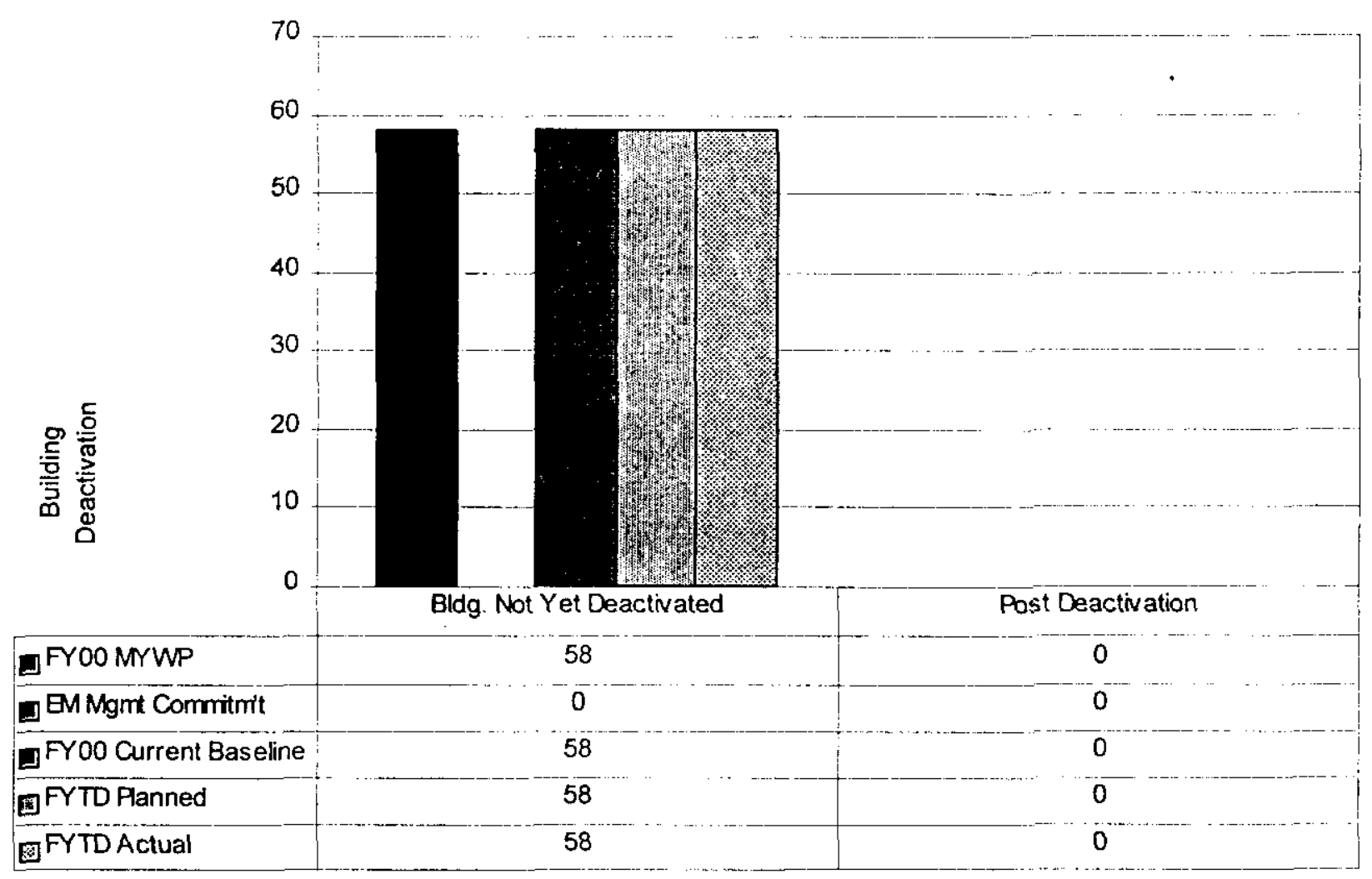

Buildings Not Yet Deactivated: Deactivation of buildings will not begin until FY 2009 as documented in the Integrated Project Management Plan for the River Corridor

Post Deactivation: There are no buildings in post deactivation. 
$\mathbf{R}_{\text {estoring the river corridor is one of the outcomes Hanford must focus on to move forward }}$

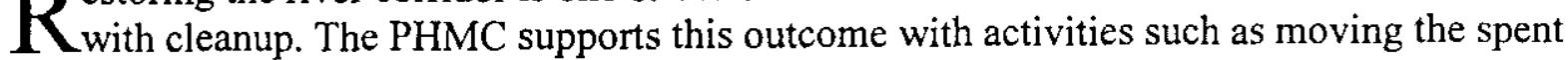
nuclear fuel, cleaning up the waste sites, and taking down surplus facilities. Projects supporting this effort are Facility Stabilization (River Corridor), Spent Nuclear Fuel, and Science \& Technology (EM - 50) activities. 

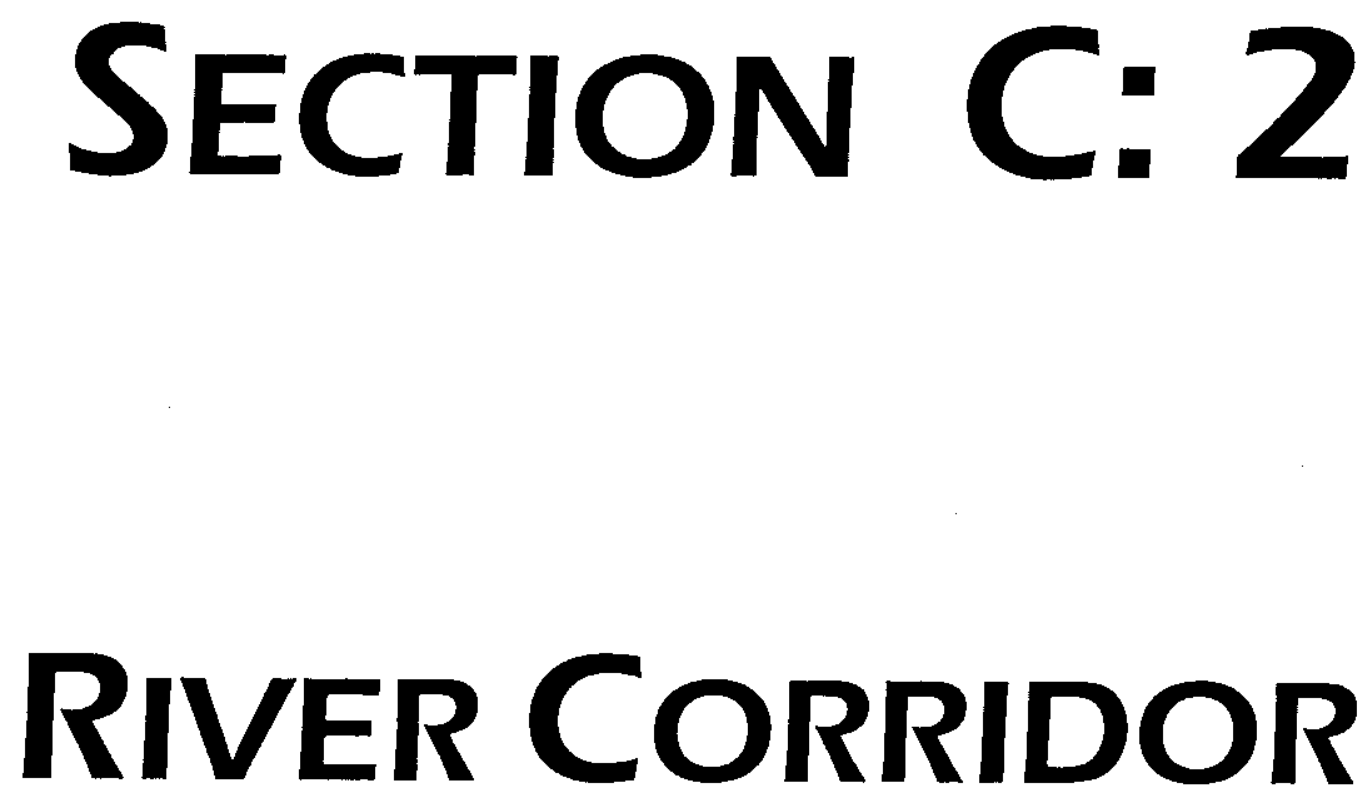

PROJECT MANAGERS

\author{
P. M. Knollmeyer, RL \\ Phone: (509) 376-7435
}

\author{
N. Boyter, FH \\ Phone: (509) 373-3725
}




\section{SUMMARY}

The River Corridor Project consists of the following projects: 300 Area Liquid Effluent Facility (LEF) WBS 1.2.3.2, Project Baseline Summary (PBS) WM05; B-Plant, WBS 1.4.1, PBS TP01; 300 Area/Special Nuclear Materials, WBS 1.4.4, PBS TP04; Transition Project Management, WBS 1.4.6, PBS TP12; Accelerated Deactivation, WBS 1.4.8, PBS TP10; 324/327 Facility Transition, WBS 1.4.10, PBS TP08; and Hanford Surplus Facility Program (300 Area Revitalization), WBS 1.4.11, PBS TP14.

PBS WM05 is divided between WBS 1.2.3.1, Liquid Effluents (200 LEF) and WBS 1.2.3.2, 310 TEDF/340 Facility (300 LEF). The 310 TEDF/340 Facility work scope is now included in the River Corridor Project, whereas the Liquid Effluents (200 LEF) work scope has remained in Waste Management. For the purpose of performance analysis, PBS WM05 is reported in its entirety in the Waste Management Project, which has the majority of the work scope and funding incorporated in their baseline.

NOTE: Unless otherwise noted, the Safety, Conduct of Operations, Milestone Achievement, Metrics and Cost/Schedule data contained herein is as of March 31, 2000. All other information is as of April 26, 2000.

Good progress was made toward closeout of the actions required by the B Plant transfer Memorandum of Agreement (MOA). Vibration testing of the ducting has been completed. The subject matter experts verified that the crack was caused by vibration from harmonics that occurred when the system was operated at a low-flow condition. The system will be run at fullflow to avoid the problem once the field repair/plate welding is complete. The Department of Health has extended the due date to June 30,2000 for restart of the exhaust system.

Progress continues toward Accelerated Deactivation of the 327 Facility with the removal of 180 of $\sim 300$ sample cans from Dry Storage. Additionally, size reduction of Pin Tubes for packaging into shielded drums is complete.

Size reduction of the 2A Rack, "clamshelling" the fallen pieces from the cell floor, and placing them in grout containers from the 324 Building B-Cell completes Milestone RL TRP-99-936.

Grout container GC-137 was shipped to the Low-Level Burial Grounds in 200 Area. Five containers have now been shipped for the 17-container campaign. These are the first containers to be shipped since the fall of 1998. The shipments close out all waste characterization and packaging, and shipping issues that have confronted the 324 team for the past $1 \frac{1}{2}$ years.

The Accelerated Deactivation project is making good progress in planning for the disposition of approximately 1,865 metric tons (MT) of Hanford Unirradiated Uranium. Responses to public comments on the Environmental Assessment (EA) have been incorporated and the revised EA is being reviewed by DOE-RL. Additionally, the Hanford Advisory Board was briefed on the intent to bury non-contaminated fuel at the Low-Level Burial Ground (LLBG). Final disposition of Unirridiated Uranium fuel elements to low-level waste burial grounds vs. packaging and 
transportation to Portsmouth, Ohio for interim storage provides the method to save in excess of $\$ 1 \mathrm{M}$ over the current Project Management Plan cost baseline. If funded and regulatory agreement is received, disposition of the Uranium fuel elements will occur in the last quarter of FY 2000. Concurrently, Phase I activities to prepare uranium billets and UO3 T-hoppers for shipment are continuing. Additional savings can be realized by consolidating shipments of Uranium billets and Uranium Oxide powder, which will save approximately $40 \%(\$ 200 \mathrm{~K})$ of the planned transportation cost to Portsmouth, Ohio. If funding is identified to support this initiative, shipment of the material to Portsmouth will occur in the June/July 2000 time frame.

The Project Management Plan for the 300 Area Special Case Waste, HNF-5068, Revision 1 (M092-14), was completed 30 months early, pending acceptance of the plan by Ecology.

Fiscal-year-to-date milestone performance (EA, DOE-HQ, and RL) shows that two of three milestones (67 percent) were completed on or ahead of schedule and one milestone is overdue. The Milestone Achievement details, found following cost and schedule variance analysis, provide further information on all milestone types.

\section{ACCOMPLISHMENTS}

- Grout container GC-137 was shipped from 324 to the Low-level Burial Grounds in 200 Area. Five containers have now been shipped for the 17-container campaign. These are the first containers to be shipped since the fall of 1998.

- The A Cell Request for Service was approved and the A Cell PVC tubes were shipped from 324 to the Low Level Burial Ground.

- Over 1 million gallons of water impacted by the citric acid upset have been successfully treated at the 300 Liquid Effluent Facility (LEF), with the process performing properly and effluent meeting discharge limits. Recovery from the process upset is complete.

- Corrective actions for access control for potential beryllium contaminated facilities in the Accelerated Deactivation organization are complete.

- The Auditable Safety Analysis and Hazard Classification for the 3706 Building are complete.

- Public comments for the Uranium Disposition National Environmental Protection Act Documentation (EA) have been incorporated, and the revised EA is being reviewed by DOE-RL.

- Removal of a total of 180 of the 300 specimen containers from Dry Storage at 327 Building and size reduction of Pin Tubes for packaging into shielded drums are complete. 
- Formation of the 300 Area Accelerated Deactivation team to develop the plan for the 300 Area Acislerated Deactivation is complete, and the kick-off of the planning has been initiated.

- NFDI hosted the multi-site joint National Facility Deactivation Initiativè and Decommissioning \& Decontamination National Committee Meeting April 25 through 27, 2000 .

\section{SAFETY}

Significant decreases in OSHA recordable case rate and in DOE Safety Cost Index have recently occurred. The project has exceeded 500,000 hours without an OSHA recordable.

The project has an overall green rating - stable at excellent rates. 

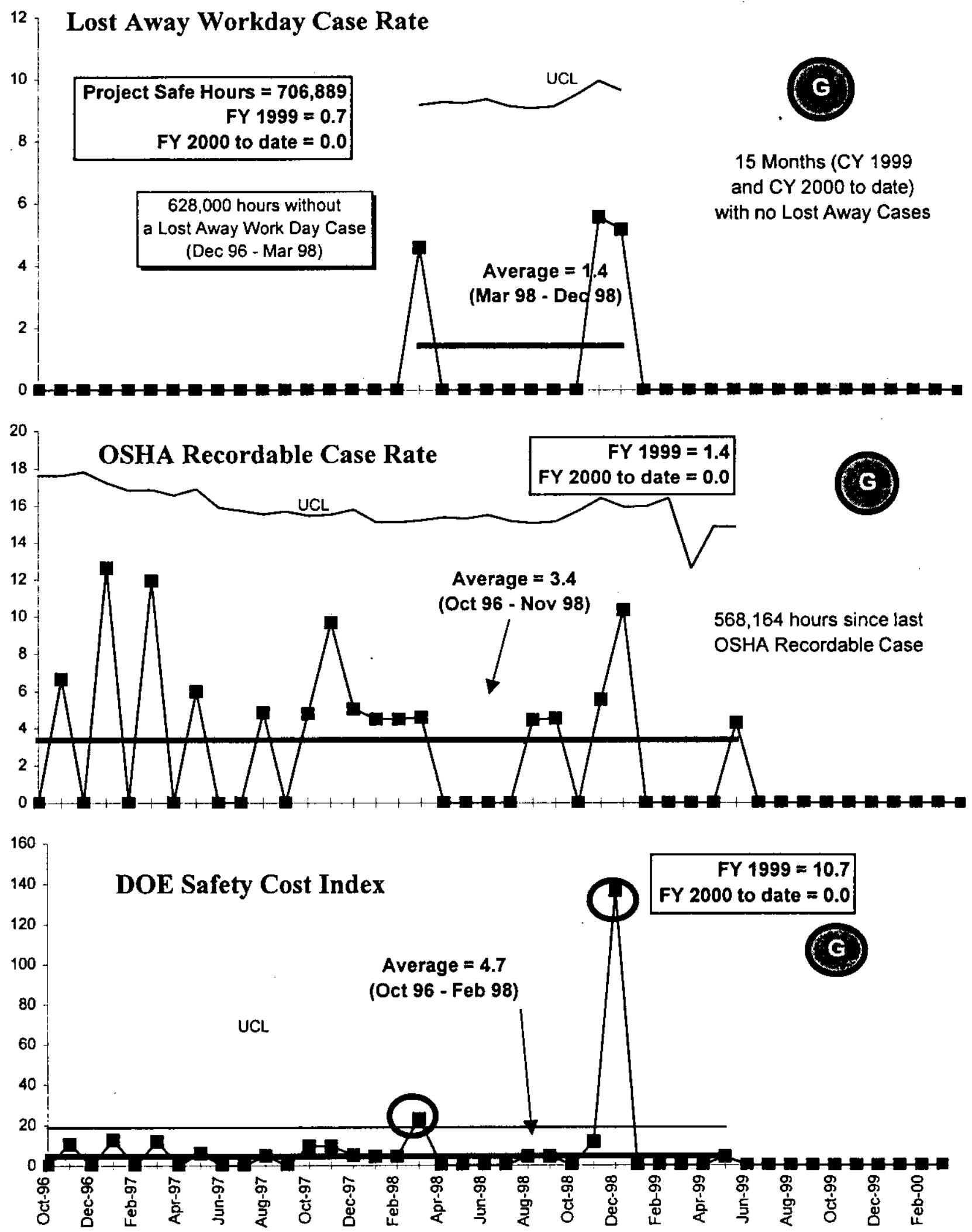


\section{CONDUCT OF OPERATIONS / ISMS STATUS}

\section{Events per 200,000 hours}
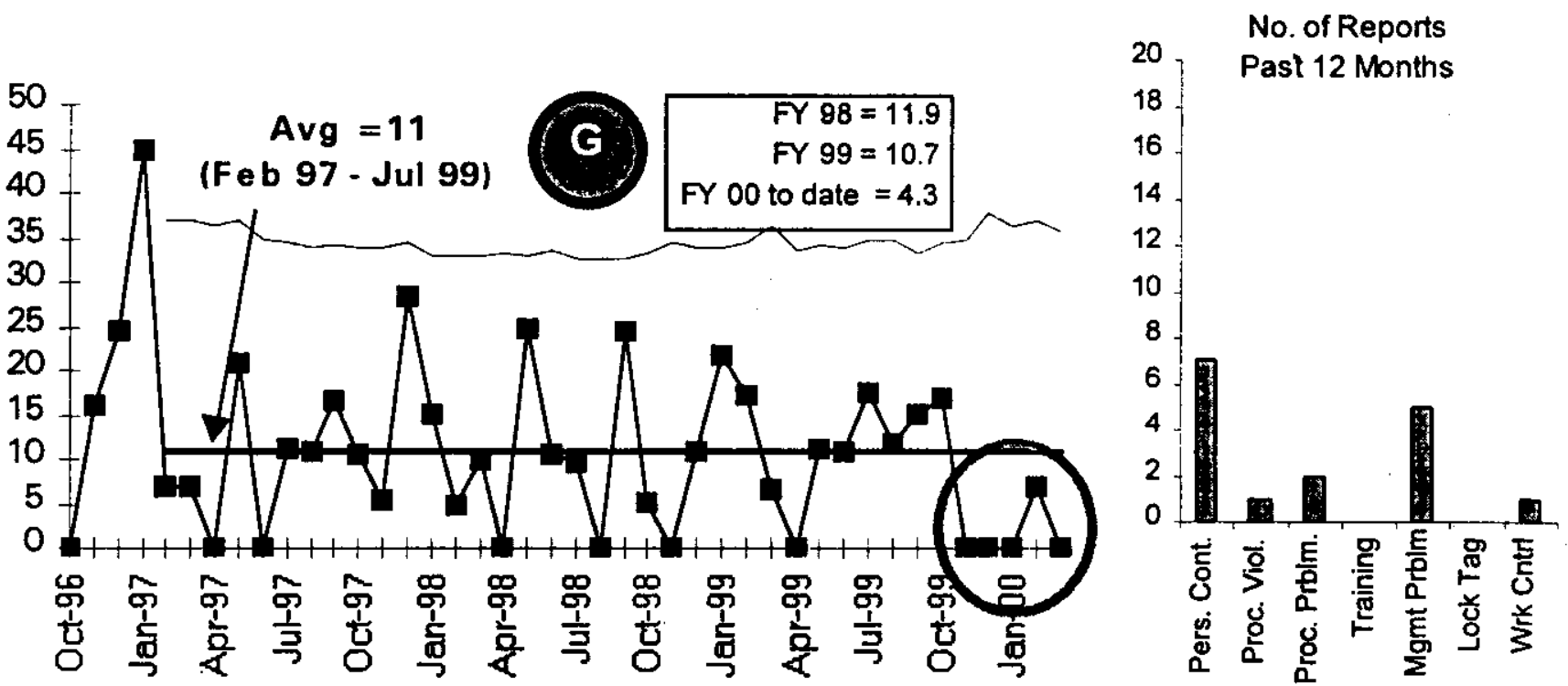

\section{ISMS STATUS}

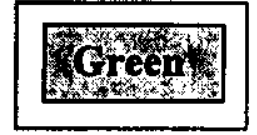

- ISMS Internal Readiness Review (IRR) completed; closure plan in progress

- Senior Management Review Board presentations completed

- $\quad$ Phase I Verification beginning April 17 and running through April 28, 2000

- $\quad$ ISMS Phase II Verification targeted for June 2000

\section{BREAKTHROUGHS / OPPORTUNITIES FOR IMPROVEMENT}

\section{BREAKTHROUGHS}

- Savings Through Alternative Disposition Strategy - Final disposition of Unirridiated Uranium fuel elements to low-level waste burial grounds vs. packaging and transportation to Portsmouth, Ohio for interim storage will save in excess of $\$ 1 \mathrm{M}$ over the current Project Management Plan cost baseline. If funded and regulatory concurrence is received disposition of the Uranium fuel elements will occur in the last quarter of FY 2000.

- $\quad 340$ Efficiencies - Efficiency initiatives have been identified to fund critical deactivation activities, i.e., Vault Tank $1 \& 2$ removal of residual Yellow heels ( 3,000 gallons). (Project held in abeyance due to higher priority work - funding redirected to support $\mathrm{K}$ Basin sludge work.) 


\section{OPPORTUNITIES FOR IMPROVEMENT}

- 324 Project Planning / Execution: Despite recent success in schedule recovery, therc is a need for continued emphasis on improved schedule management to ensure that critical path negative float is recovered to positive float. Current actions are directed at organization shift to projects and improving crane availability.

- Consolidating Uranium Shipments - Consolidating shipments of Uranium billets and Uranium Oxide powder will save approximately $40 \%(\$ 200 \mathrm{~K})$ off the planned transportation cost to Portsmouth, Ohio. If funding is identified to support this super stretch initiative, shipment of the material to Portsmouth will occur in the June/July 2000 time frame.

\section{UPCOMING ACTIVITIES}

- B Plant Transfer to ERC - Complete closeout activities by June 30, 2000.

- Integrated Environmental, Safety \& Health Management System (ISMS) Complete verification of Phase I \& II readiness activities by June 2000.

- 300 Area Accelerated Closure Project Plan - Prepare and issue the 300 Area Accelerated Closure Project Plan, schedule and estimate July 3, 2000.

- $\quad 300$ Area Waste Acid Treatment System (WATS) Resource Conservation and Recovery Act (RCRA) Closure Activities - The final report due to RL has been delayed until September 2000 due to the review and comment cycle with Washington Department of Ecology (WDOE). A baseline change request has been submitted to delete the milestone, TRP-99-301, "Submit Final Report on WATS Closure Activities to RL."

- $\quad$ TPA Milestone M-89-02 — Complete Removal of 324 Building Radiochemical Engineering Cell (REC) B Cell Mixed Waste (MW) and Equipment by November 2000.

\section{Cost Performance $(\$ M):$}

\begin{tabular}{|l|c|c|c|}
\hline & BCWP & ACWP & VARIANCE \\
\hline River Corridor Project & $\$ 26.3$ & $\$ 26.0$ & $+\$ 0.3$ \\
\hline
\end{tabular}

The $\$ 0.3$ million (1.0 percent) favorable cost variance is within the established threshold. Further information at the PBS level can be found in the following Cost Variance Analysis details. 


\section{Schedule Performance ( $\$ M)$ :}

\begin{tabular}{|l|c|c|c|}
\hline & BCWP & BCWS & VARIANCE \\
\hline River Corridor Project & $\$ 26.3$ & $\$ 27.0$ & $-\$ 0.7$ \\
\hline
\end{tabular}

The $\$ 0.7$ million (3.0 percent) unfavorable schedule variance is within the established threshold. Further information at the PBS level can be found in the following Schedule Variance Analysis details.

\section{FY 2000 Cost/SChedule Performance - All Fund Types Cumulative to Date Status - (\$000)}

\begin{tabular}{|c|c|c|c|c|c|c|c|c|c|c|c|c|c|c|c|}
\hline \multirow{2}{*}{\multicolumn{2}{|c|}{ By PBS }} & \multicolumn{13}{|c|}{ FYTD } & \multirow[b]{2}{*}{ PEM } \\
\hline & & \multicolumn{2}{|c|}{ BCWS } & \multicolumn{2}{|c|}{ BCWP } & \multicolumn{2}{|c|}{ ACWP } & \multicolumn{2}{|c|}{ SV } & \multicolumn{2}{|l|}{$\%$} & $\mathrm{CV}$ & $\%$ & & \\
\hline $\begin{array}{l}\text { PBS TP01 } \\
\text { WBS 1.4.1 }\end{array}$ & B-Plant & $\mathbf{S}$ & - & $\mathbf{s}$ & - & $\mathbf{s}$ & 397 & $\mathbf{s}$ & - & $0 \%$ & $\mathbf{s}$ & (397) & $0 \%$ & $\mathbf{s}$ & - \\
\hline $\begin{array}{l}\text { PBS TP04 } \\
\text { WBS 1.4.4 }\end{array}$ & $\begin{array}{c}300 \text { Area/ Special Nuclear } \\
\text { Materials }\end{array}$ & $\mathbf{s}$ & 1,295 & $\mathbf{s}$ & 1,285 & $\mathbf{s}$ & 1,286 & $\mathbf{s}$ & $(10)$ & $-1 \%$ & s & (1) & $0 \%$ & $\mathbf{s}$ & 2,686 \\
\hline $\begin{array}{l}\text { PBS TP12 } \\
\text { WBS } 1.4 .6\end{array}$ & Transition Program Management & $\mathbf{s}$ & 9,201 & $\mathbf{s}$ & 9,250 & $\mathbf{s}$ & 7,405 & $\mathbf{S}$ & 48 & $1 \%$ & s & 1,845 & $20 \%$ & $\mathbf{S}$ & 19,408 \\
\hline $\begin{array}{l}\text { PBS TP10 } \\
\text { WBS } 1.4 .8\end{array}$ & Accelerated Deactivation & $\mathbf{s}$ & 1,149 & $\mathbf{s}$ & 1,150 & s & 1,064 & $\mathbf{S}$ & 1 & $0 \%$ & $\mathbf{S}$ & 86 & $7 \%$ & $\mathbf{S}$ & 2,430 \\
\hline $\begin{array}{l}\text { PBS TP08 } \\
\text { WBS } 1.4 .10\end{array}$ & 324/327 Facility Transition & $\mathbf{s}$ & 15,017 & $s$ & 14,321 & $s$ & 15,591 & $S$ & (696) & $-5 \%$ & 5 & $(1,270)$ & $.9 \%$ & $\mathbf{S}$ & 34,683 \\
\hline $\begin{array}{l}\text { PBS TP14 } \\
\text { WBS } 1.4 .11\end{array}$ & $\begin{array}{l}\text { Hanford Surplus Facility Program } \\
\text { (300Area Revitalization) }\end{array}$ & $\mathbf{s}$ & 359 & 5 & 303 & $\mathbf{S}$ & 244 & 5 & (56) & $-16 \%$ & $S$ & 59 & $19 \%$ & $\$$ & 664 \\
\hline & Total & $\mathbf{s}$ & 27,021 & $\mathbf{s}$ & 26,309 & $s$ & 25,988 & s & (711) & $-3 \%$ & $s$ & 322 & $1 \%$ & $s$ & 59,871 \\
\hline
\end{tabular}




\section{Cost/SChedule Performance Indices (MARCH 2000 AND FYTD)}

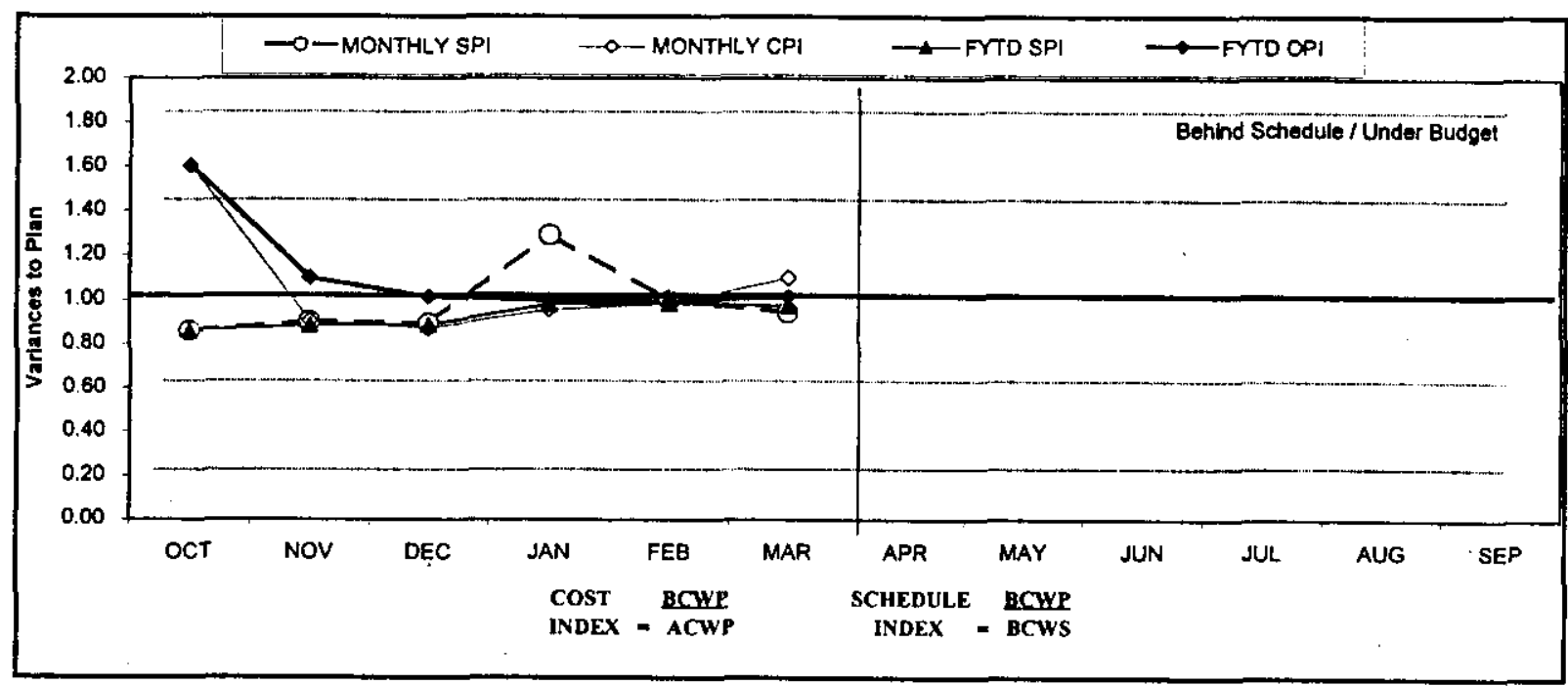

\begin{tabular}{|c|c|c|c|c|c|c|c|c|c|c|c|c|}
\hline FY 2000 & OCT & NOV & DEC & JAN & FEB & MAR & APR & MAY & JUN & JUL & AUG & SEP \\
\hline MONTHLY SPI & 0.86 & 0.90 & 0.89 & 1.29 & 1.00 & 0.94 & & & & & & \\
\hline MONTHLY CPI & 1.60 & 0.90 & 0.87 & 0.96 & 0.98 & $1 . \overline{10}$ & & & & & & \\
\hline FYTD SPI & 0.86 & 0.88 & 0.89 & 0.98 & 0.98 & 0.97 & & & & & & \\
\hline FYTOCPI & 1.60 & 1.10 & 1.01 & 0.99 & 0.99 & 1.01 & & & & & & \\
\hline MONTHLY BCWS & $\$ 3,649$ & $\$ 5,158$ & $\$ 4,089$ & $\$ 3,855$ & $\$ 4,290$ & $\$ 5,980$ & $\$ 4,983$ & $\$ 6,535$ & $\$ 4,751$ & $\$ 4,764$ & $\$ 6,409$ & $\$ 5,410$ \\
\hline MONTHLY BCWP & $\$ 3.131$ & $\$ 4,646$ & $\$ 3,654$ & $\$ 4,973$ & $\$ 4.270$ & $\$ 5,635$ & & & & & & \\
\hline MONTHLY ACWP & $\$ 1,854$ & 55.141 & $\$ 4,195$ & $\$ 5,206$ & $\$ 4,357$ & $\$ 5,135$ & & & & & & \\
\hline FYTD BCWS & $\$ 3,649$ & $\$ 8.807$ & $\$ 12,896$ & $\$ 16,751$ & $\$ 21,041$ & $\$ 27,021$ & $\$ 32.004$ & $\$ 38,539$ & $\$ 43,289$ & $\$ 48,053$ & $\$ 54.462$ & $\$ 59,871$ \\
\hline FYTD BCWP & $\$ 3,131$ & $\$ 7.777$ & $\$ 11,431$ & $\$ 16,404$ & $\$ 20,674$ & $\$ \quad 26,309$ & & & & & & \\
\hline FYTD ACWP & $\$ 1,954$ & $\$ 7,095$ & $\$ 11,290$ & $\$ 16,496$ & $\$ 20,853$ & $\$ 25,988$ & & & & & & \\
\hline
\end{tabular}

\section{COST VARIANCE ANALYsIS: (+\$0.3M)}

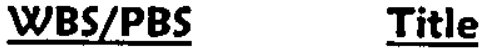

\subsection{1/TP01 B Plant}

Description and Cause: The unfavorable cost variance is due to unplanned costs associated with the ventilation filter change outs and ductwork repairs.

Impact: Deprives other projects of funding for current year priorities including accelerated deactivation activities.

Corrective Action: Work scope is being performed via an approved Advanced Work

Authorization (AWA) while BCR FSP-00-008, which incorporates the B Plant action items into the baseline, is dispositioned.

\subsection{6/TP12 Transition Project Management}

Description and Cause: While the subproject is reporting a favorable cost variance of $\$ 1,845 \mathrm{~K}$, the actual status is a favorable cost variance of $\$ 36 \mathrm{~K}$. The favorable cost variance is primarily due to the PHMC re-structuring which has mapped personnel from the sub-project to other subprojects (i.e. Nuclear Material Stabilization), resulting in underruns in labor and contractor support. 
Impact: The current Fiscal Year Spend Forecast (FYSF) projects a $\$ 1.2 \mathrm{M}$ unfavorable condition at fiscal year end for River Corridor. (Note: Funding has been identified.)

Corrective Action: Re-planning of this account is underway to reflect the new structure, including the transfer of funds to other PHMC sub-projects where former Facility Stabilization personnel have been mapped. A BCR FSP-2000-038 is in preparation to document the split of the sub-project. If incremental funding is not identified RCP project impacts will be incurred. (Note: Funding has been identified.)

\subsubsection{0/TP08 324/327 Building Deactivation}

Description and Cause: The unfavorable cost variance is primarily due to performance of unfunded accelerated 327 Building deactivation work scope via AWA (super stretch performance incentive). This is partially offset by efficiencies that are being realized in both the performance of MinSafe activities and deactivation scope.

Impact: None. Spending against AWAs is being closely monitored.

Corrective Action: Costs of work being performed via AWA will be measured against baseline performance once the applicable baseline change requests are approved.

\subsection{8/TP10 Accelerated Deactivation}

Description and Cause: The unfavorable cost variance is due to an incorrect accrual amount posted on the NFDI contract.

Impact: None.

Corrective Action: The incorrect accrual will be reversed and entered correctly in April.

\subsubsection{1/TP14 HSFP 300 Area Revitalization}

Description and Cause: The favorable cost variance is primarily due to lower than planned costs in Min Safe surveillance and corrective maintenance activities.

Impact: None.

Corrective Action: Funds made available via underruns will be utilized toward achievement of accelerated deactivation activities.

All other PBS variances are within established thresholds.

\section{SCHEDUle VARIANCE ANALYSIS: (-\$0.7M)}

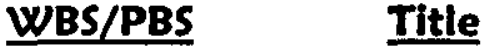

\subsubsection{1/TP14 HSFP 300 Area Revitalization}

Description and Cause: The unfavorable schedule variance is due to delays in performing the baseline estimate update activities. Changes in organization associated with the PHMC restructuring have caused the delay as a result of personnel performing other planned work either within sub-project or other areas.

Impact: None.

Corrective Action: The estimate update may not be required due to the 300 Area Accelerated Closure Plan Project planned via BCR FSP-2000-024, which was approved in March.

All other PBS variances are within established thresholds. 


\section{ISSUES}

\section{TECHNICAL ISSUES}

Issue: Shipping of ten grout containers filled with 1A Rack to be completed by May 2000. One has curie levels above limits allowed for shipment.

Impact: New Safety Analysis Report for Packaging (SARP) will be required for single high-curie container. RL Milestone TRP-99-907 currently states all 1A Rack grout containers are to be shipped by May 2000.

Corrective Action: Informal negotiations have begun between $\mathrm{RL}$ and $\mathrm{FH}$ to substitute another container from the B Cell, but still ship ten grout containers. Baseline Change Request is being drafted; no funding or schedule change required.

Issue: The 324 Building Fire Hazards Analysis (FHA) revision supporting the 324 Building Safety Analysis Report (SAR) update resulted in revised combustible load limits.

Impact: There is a potential adverse cost impact to work progress at the 324 Building. Corrective Action: An implementation plan that allows work to continue while maintaining revised combustible load limits or invoking compensatory measures has been submitted. Evaluation of alternative fire suppression capabilities to allow an increase in combustible load limits continues. This will be the last report on this issue.

Issue: A crack was discovered on the new B Plant W-059 Duct Replacement.

Impact: Possible delay to completion of B Plant turnover Memorandum of Agreement. Corrective Action: Vibration testing of the ducting has been completed. The problem was verified to have been caused by harmonics. The system will be run at full flow to avoid the problem after field repair/plate welding is complete. The Department of Health has extended the due date to June 30,2000 for restart of the exhaust system. This will be the last report on this issue.

\section{DOE/REGULATOR/EXTERNAL ISSUES}

Issue: Approval by the U.S. Department of Energy - Headquarters (DOE-HQ) of the Unirradiated Uranium (UU) billet Safety Analysis Report for Packaging (SARP) is required by May 31, 2000. Performance Incentives encourage the accelerated disposition of this material; however, review and approval time frames do not support attempts to accelerate shipments.

Impact: Failure to gain approval on or before May 31, 2000 will jeopardize the combined shipment of UU billets and T-Hoppers, thus losing the opportunity to save approximately $\$ 200,000$ in FY 2000. Performance Incentive RC3-SS Uranium Disposition will be impacted by the inability to ship billets and T-Hoppers in FY 2000.

Corrective Action: A revision to the SARP, which limits the amount of criticality analysis, may expedite the review process. Timely DOE-HQ review and approval of billet Safety Analysis Report for Packaging (SARP) is critical for disposition. 
Issue: Timely receipt of the U. S. Department of Energy - Richland (RL) review/comments on the Steel Waste Disposal Box (SWDB) Safety Analysis Report for Packaging (SARP) is critical to maintain the schedule for Tri-Party Agreement interim milestone M-89-02. The SARP was submitted to RL on February 4. In accordance with the 324/327 Buildings Stabilization/ Deactivation Project, Project Management Plan (PMP) (HNF-IP-1289, Rev. 3), the completion date for this review was March 31.

Impact: A further delay will place the project at risk in both cost and the Hanford Federal Facility Agreement and Consent Order (Tri-Party Agreement) interim milestone M-89-02 schedule. Fabrication and receipt of the SWDBs now proceed ahead of SARP completion, and it is estimated that the first SWDB will be received from the manufacturer prior to SARP approval. If Fluor Hanford (FH) delays the fabrication and receipt of these $S W D B s$, they will not be received in time. If design-altering comments are received from $R L$ at this point, rework of the received box(es) will be required, at a significant cost, and with the potential to impact or delay Tri-Party Agreement interim milestone M-89-02.

Corrective Action: The contractor will work closely with RL staff to support/facilitate the timely review of the SARP.

Baseline Change Requests Currently in Process $(\$ 000)$

\begin{tabular}{|c|c|c|c|c|c|c|c|c|c|}
\hline $\begin{array}{l}\text { PROECT } \\
\text { CHANCE } \\
\text { NMBER }\end{array}$ & $\begin{array}{l}\text { DATE } \\
\text { ORICIN }\end{array}$ & BCR ITRE & $\begin{array}{l}\text { FYOO COST } \\
\text { WPACT }\end{array}$ & $\mathrm{SCH}$ & TECH & $\begin{array}{l}\text { DATE } \\
\text { TOCOB }\end{array}$ & $\underset{\text { APRM }}{\operatorname{Cos}}$ & $\underset{A P R V D}{R L}$ & $\begin{array}{l}\text { CURENT } \\
\text { STATUS }\end{array}$ \\
\hline 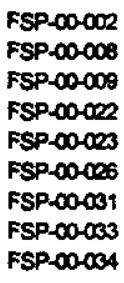 & $\begin{array}{l}11 / 2 / 99 \\
12 / 3 / 90 \\
12 / 9 / 99 \\
1 / 31 / 00 \\
2 / 6100 \\
2 / 2900 \\
3 / 20100 \\
3 / 23100 \\
3 / 2400\end{array}$ & 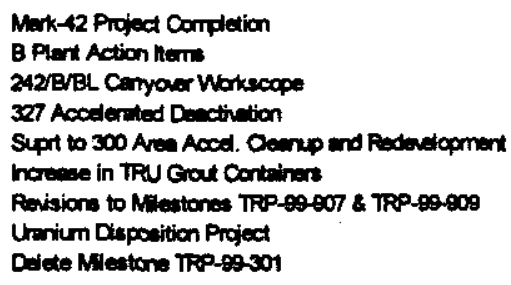 & $\begin{array}{l}\$ 0 \\
\$ 58 \\
\$ 36 \\
\$ 4,573 \\
2290 \\
? \\
\infty \\
\infty \\
\infty\end{array}$ & $x$ & $\begin{array}{l}x \\
x \\
x \\
x \\
x \\
x\end{array}$ & 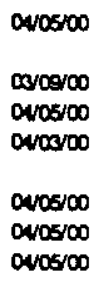 & $\begin{array}{l}\text { RMOA } \\
\text { O4/7/100 } \\
\text { O40S100 } \\
0413 / 00\end{array}$ & NA & 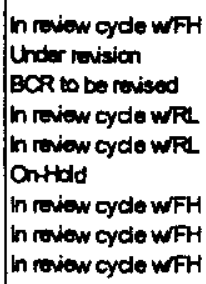 \\
\hline \multicolumn{10}{|c|}{ AOVANCE WOFK AUTHOAZATONS } \\
\hline $\begin{array}{l}\text { AWA } \\
\text { AWA }\end{array}$ & $\begin{array}{l}10 / 1 / 99 \\
2 / 2400\end{array}$ & $\begin{array}{l}327 \text { Stabilizationdenctivtion Project } \\
\text { Uranium Oisporition Project }\end{array}$ & $\begin{array}{l}\$ 1,500 \\
\$ 50\end{array}$ & $\begin{array}{l}x \\
x\end{array}$ & $\begin{array}{l}x \\
x\end{array}$ & & & $\begin{array}{l}02 / 07 / 00 \\
03 / 00 / 00\end{array}$ & $\begin{array}{l}B C R=S P-00-002 \\
B C R=S P-C 0-003\end{array}$ \\
\hline
\end{tabular}

MILESTONE ACHIEVEMENT

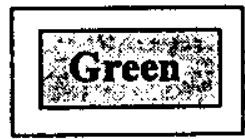

\begin{tabular}{|r|r|r|r|r|r|r|r|r|}
\hline & \multicolumn{4}{|c|}{ FISCAL YEAR-TO-DATE } & \multicolumn{2}{c|}{ REMAINING SCHEDULED } \\
\cline { 2 - 8 } MILESTONE TYPE & $\begin{array}{c}\text { Completed } \\
\text { Early }\end{array}$ & $\begin{array}{c}\text { Completed On } \\
\text { Schedule }\end{array}$ & $\begin{array}{c}\text { Completed } \\
\text { Late }\end{array}$ & Overdue & $\begin{array}{c}\text { Forecast } \\
\text { Early }\end{array}$ & $\begin{array}{c}\text { Forecast } \\
\text { On } \\
\text { Schedule }\end{array}$ & $\begin{array}{c}\text { Forecast } \\
\text { Late }\end{array}$ & $\begin{array}{c}\text { TOTAL } \\
\text { FY } \\
2000\end{array}$ \\
\hline Enforceable Agreement & 1 & 0 & 0 & 0 & 0 & 0 & 0 & 1 \\
\hline DOE-HQ & 0 & 0 & 0 & 0 & 0 & 0 & 0 & 0 \\
\hline RL & 0 & 1 & 0 & 1 & 0 & 3 & 0 & 5 \\
\hline Total Project & 1 & 1 & 0 & 1 & 0 & 3 & 0 & 6 \\
\hline
\end{tabular}




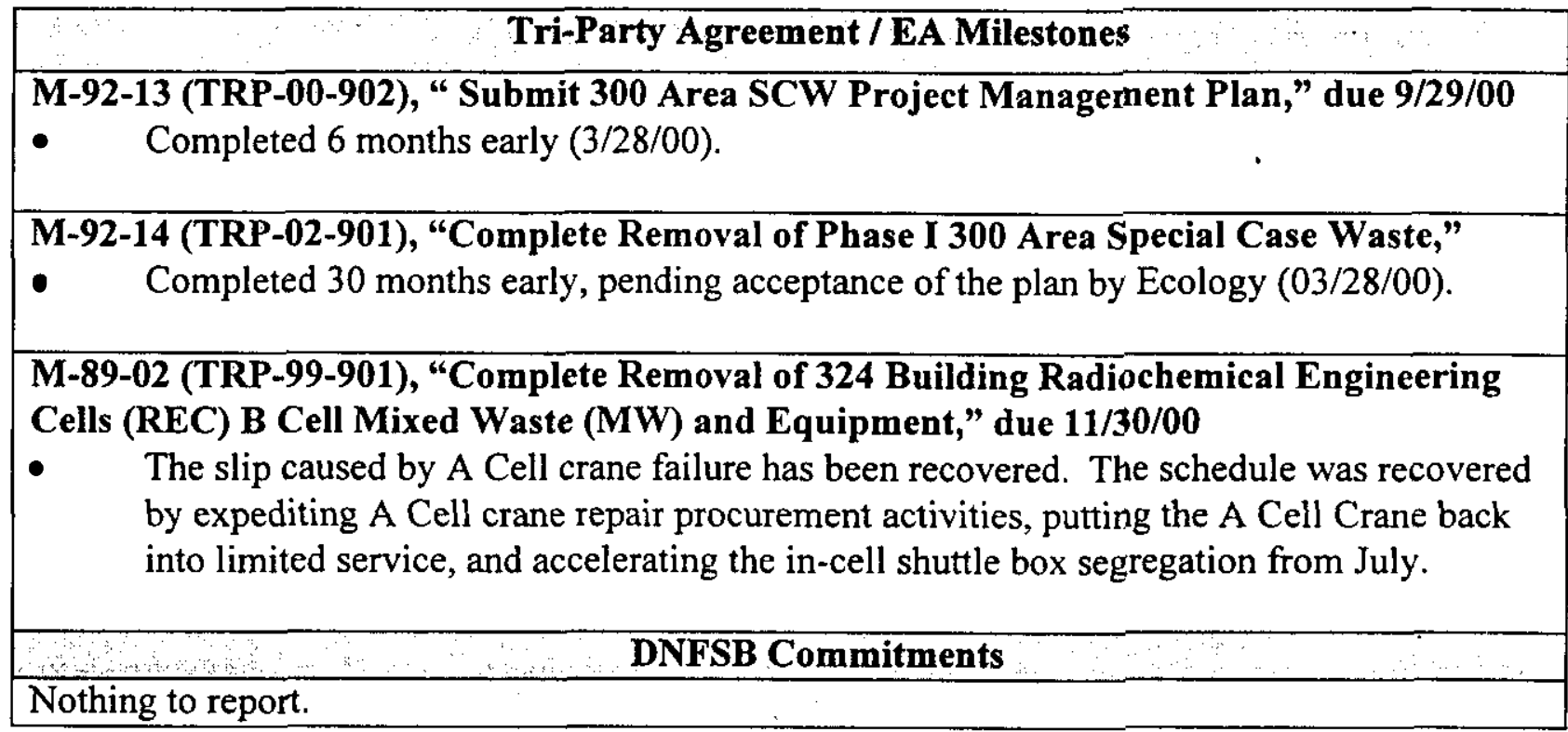

\section{MILESTONE EXCEPTION REPORT}

\begin{tabular}{|c|c|c|}
\hline caymang & evel & itle \\
\hline
\end{tabular}

\section{OVerdue - 1}

TRP-99-301 RL Submit Final Report on WATS Closure $\quad 03 / 31 / 00 \quad 09 / 29 / 00$ 1.4.4 Activities to DOE-RL

Cause: This report must include information obtained after the WDOE approves the Hanford Site RCRA permit which also includes the WATS permit. WDOE approval is not expected until late spring, consequently delaying the final report submittal until September 2000.

Impact: No impact. Does not delay any fieldwork.

Corrective Action: A change request has been prepared to delete this milestone.

\section{FORECAST LATE - 0}

\section{FY 1999 OVERDUE - 1}

TRP-99-800 RL End Point Improvement Method 06/25/99 To Be

\subsubsection{Deleted}

Cause: Resources necessary to complete this milestone were diverted to other priority work.

This milestone represents an enhancement in Facility Stabilization Project's ability to plan deactivation work, but it is not essential. 
Impact: No impact. This work scope is independent of PMBS critical path and does not impact any schedule.

Corrective Action: Deletion of this milestone is included in the BCR which re-baselines TP-10 and is currently in development.

\section{Performance Objectives}

\begin{tabular}{|c|c|c|}
\hline Outcome & Performance Indicator & Status \\
\hline \multirow{3}{*}{$\begin{array}{l}\text { Restore } \\
\text { the River } \\
\text { Corridor } \\
\text { for } \\
\text { Multiple } \\
\text { Uses }\end{array}$} & $\begin{array}{l}\text { FDH-RC-2 } \\
\text { Accelerate 324/327 } \\
\text { Deactivation }\end{array}$ & On track - no issues. BCR approved by RL. \\
\hline & $\begin{array}{l}\text { RDH-RC-2SS } \\
\text { Continue Acceleration of } \\
324 / 327 \text { Deactivation - } \\
\text { Complete } 327 \text { Facility } \\
\text { accelerated deactivation } \\
\text { activities by September } \\
2000 \text {. }\end{array}$ & $\begin{array}{l}\text { Good progress is being made in cleanout and packaging of selected legacy } \\
\text { waste material. While excellent progress is being made on selected } \\
\text { waste/material, not all targeted workscope in the super-stretch initiative will be } \\
\text { completed this year. Required funding has been identified }(04 / 06 / 00) \text { to } \\
\text { support substantive progress toward this initiative. }\end{array}$ \\
\hline & $\begin{array}{l}\text { Disposition Uranium } \\
\text { Complete disposition of } \\
\text { 1865 Metric Tons (MT) } \\
\text { of Hanford Uranium by } \\
\text { September } 2000 .\end{array}$ & $\begin{array}{l}\text { Incorporated public response to the Environmental Assessment (EA). Position } \\
\text { paper on disposal of fuel elements in Low-Level Burial Ground (LLBG) } \\
\text { submitted to DOE-RL. Continuing with Phase I activities to prepare uranium } \\
\text { billets, UO3 T-hoppers for shipment. Additional funds are required by May } \\
2000 \text { to initiate Phases II and III to complete this work activity by yearend. } \\
\text { Advance Work Authorization to exchange work between Tasks } 1 \text { and } 2 \\
\text { approved by DOE-RL. Baseline change request approved April } 13,2000 \text {. }\end{array}$ \\
\hline Multiple & $\begin{array}{l}\text { Comprehensive } \\
\text { performance }\end{array}$ & All baseline work projected to be complete per PI requirements. \\
\hline
\end{tabular}

\section{KEY INTEGRATION ACTIVITIES}

- Complete National Facility Deactivation Initiative (NFDI) DOE-complex implementation plan.

- The RCP 324 Building B Cell project, along with Spent Nuclear Fuel (SNF) developed an alternative plan for the fuel removal activity. Agreement to use a longer inner canister for the fuel permits greater end shielding and allows manual welding and testing in the Cask Handling Area (CHA) rather than the more expensive, remote effort in B Cell. SNF and DOE-RL are reviewing the options study to determine cost savings against the 200 Area Interim Storage life cycle costs. Following the review, a memorandum of agreement will be issued documenting the interface between SNF and RCP. 
- The DOE-HQ funded study of HLV Tank 105, located in the 324 Building is being conducted by AEA Technologies to identify and demonstrate the most effective technologies for deactivation of high dose radioactive tanks. The project technical plan, and implementation plan is completed while the draft of the alternatives assessment is in process.

- An integrated project team comprised of Fluor Hanford, Inc., Bechtel Hanford, Inc., and Pacific Northwest National Laboratory has been assembled to prepare a 300 Area Accelerated Closure Plan.

\section{Building Deactivation}

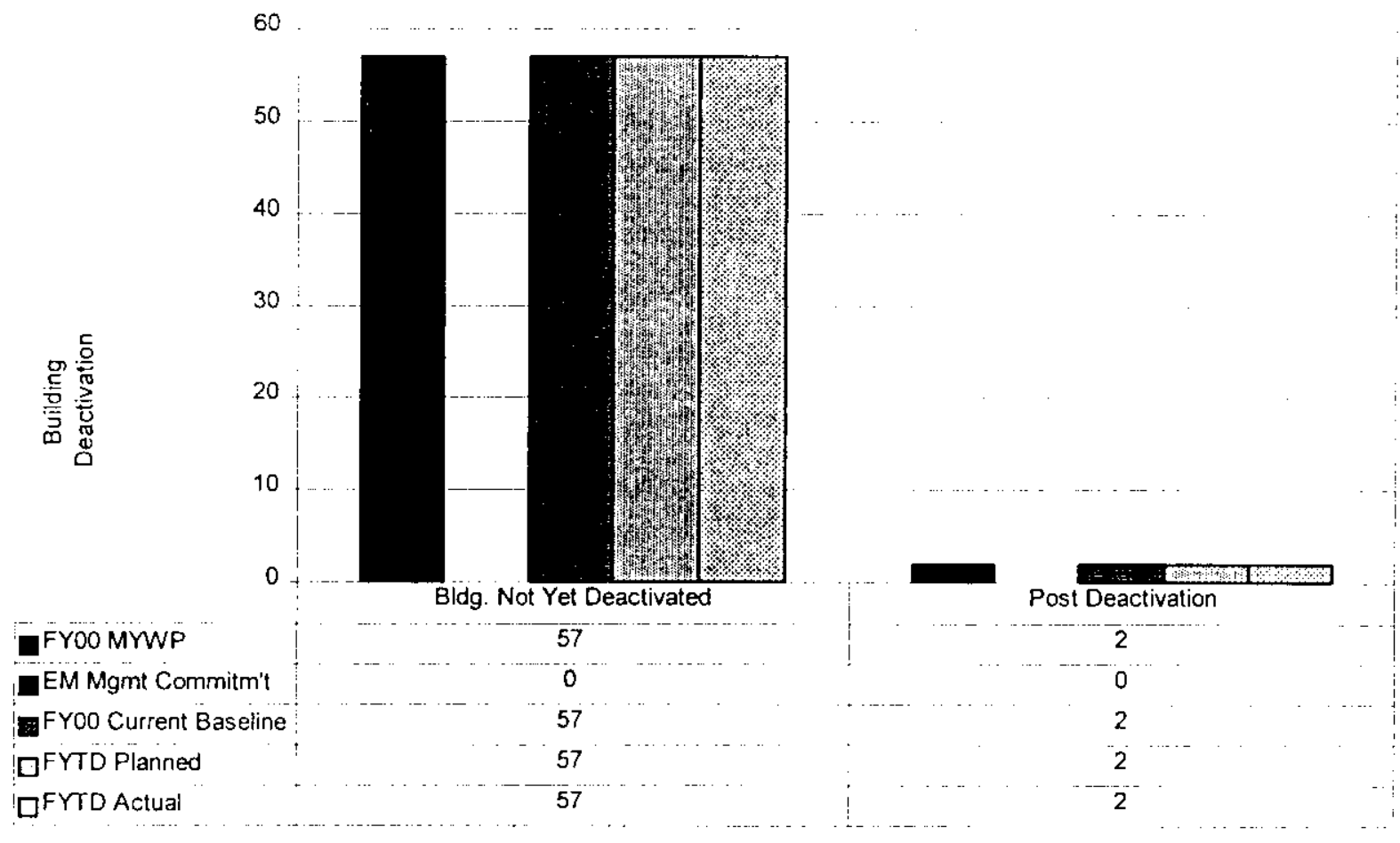

Buildings Not Yet Deactivated: Current approved budget does not fund building deactivation in the 300 area. Therefore, plans for deactivation have been deferred to FY 2002.

Post Deactivation: These are two storage buildings to be turned over to BHI when the 324/327 Transition Project is completed in FY 2007. 

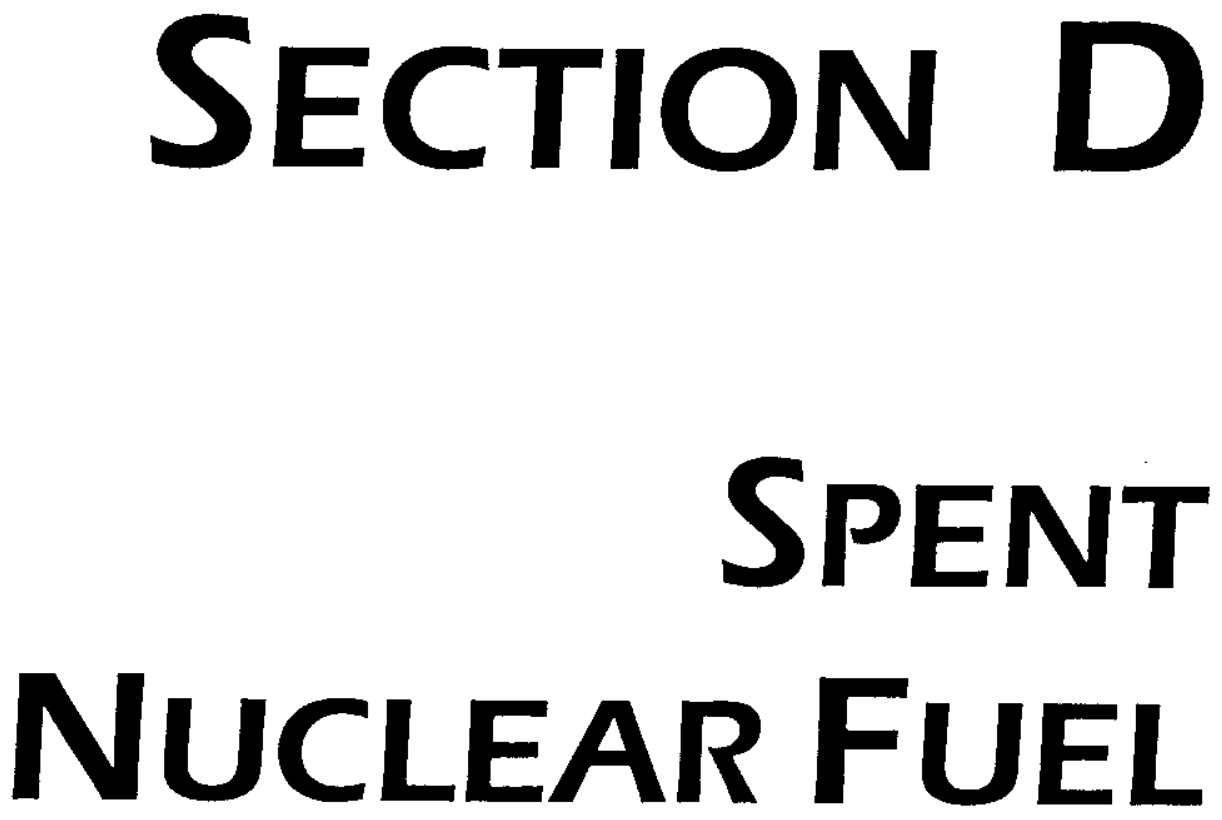

PROJECT MANAGERS

\author{
P. G. Loscoe, RL \\ Phone: (509) 373-7465 \\ R. G. Jones, FH \\ Phone: (509) 376-1413
}




\section{SUMMARY}

The Spent Nuclear Fuel (SNF) mission consists of the Spent Nuclear Fuel Project WBS 1.3.1.1 (Project Baseline Summary [PBS] WM01) and the subsequent Canister Storage. Building (CSB) Operations Project WBS 1.3.2.1 (PBS WM02), which doesn't start until FY 2004.

NOTE: Unless otherwise noted, the Safety, Conduct of Operations, Milestone Achievement, and Cost/Schedule data contained herein is as of March 31,2000. All other information is as of April $18,2000$.

The first four Multi-Canister Overpacks (MCOs) were shipped from Joseph Oat, Inc. Fabrication of the MCO baskets continued at the Hanford Site.

Pre-operational Acceptance Testing of systems within Bays 4 and 5 of the Cold Vacuum Drying (CVD) Facility continued. Fabrication of equipment for installation in Bay 3 also continued. The integrated MCO/Process Pre-operational Acceptance Test continued; initiated testing with dummy fuel.

Fiscal year-to-date milestone performance (EA, DOE-HQ, and RL) shows that two out of three milestones were completed on or ahead of schedule and one milestone was overdue as of the end of March. The Milestone Achievement details, found following cost and schedule variance analysis, provide further information on all milestone types.

\section{ACCOMPLISHMENTS}

- $\quad$ The Baseline Change Request (BCR) for the sludge acceleration strategy was approved by RL. This strategy will accelerate completion of sludge removal from the $\mathrm{K}$ Basins by one year, while reducing the SNF Project total project cost by approximately $\$ 16$ million.

- $\quad$ Received RL approval of the SNF Project Safety Authorization Basis documents for fuel removal from $K$ Basins, including CSB FSAR and TSR documents, SNF Project FSAR Volume 1, CVD Facility FSAR and TSR documents, and MCO Topical Report.

- $\quad$ Phase Startup Initiative (PSI) Phase 1 and II testing activities continued. Component tests of the Integrated Water Treatment System (IWTS) and the Fuel Retrieval System (FRS) were completed successfully.

- Initiated the integrated Multi-Canister Overpack (MCO)/Process Pre-operational Acceptance Test (PAT). This integrated test is being conducted after all subsystems' tests have been successfully performed, and when completed, it will demonstrate that the installed process equipment meets its performance criteria for safely drying fuel.

- Initiated work efforts in support of the Sludge Acceleration BCR.

- Began installation of Canister Storage Building Overpack Tubes. 
- $\quad$ Completed Baseline Drying Test for the Cold Vacuum Drying.

- The first four MCOs were shipped from Joseph Oat, Inc.

\section{SAFETY}

Although the SNF Project experienced some safety performance degradations with the start of FY 2000, performance appears to be recovering. October 1999 had two Restricted Workday Cases, and one Lost Away Workday Case. This was a nearly significant increase (close to but not above the UCL) on the OSHA Recordable Case Rate, and a significant increase (above the UCL) on the Lost / Restricted Workday Case Rate (which is a supplemental graph). The project has achieved almost 750,000 safe work hours. The past nine of ten months for the DOE Cost Index and Severity Rate have been below average.

The project's safety record is improving in both OSHA recordables and DOE Cost Index. Lost away overall has had only one case in the past year. 

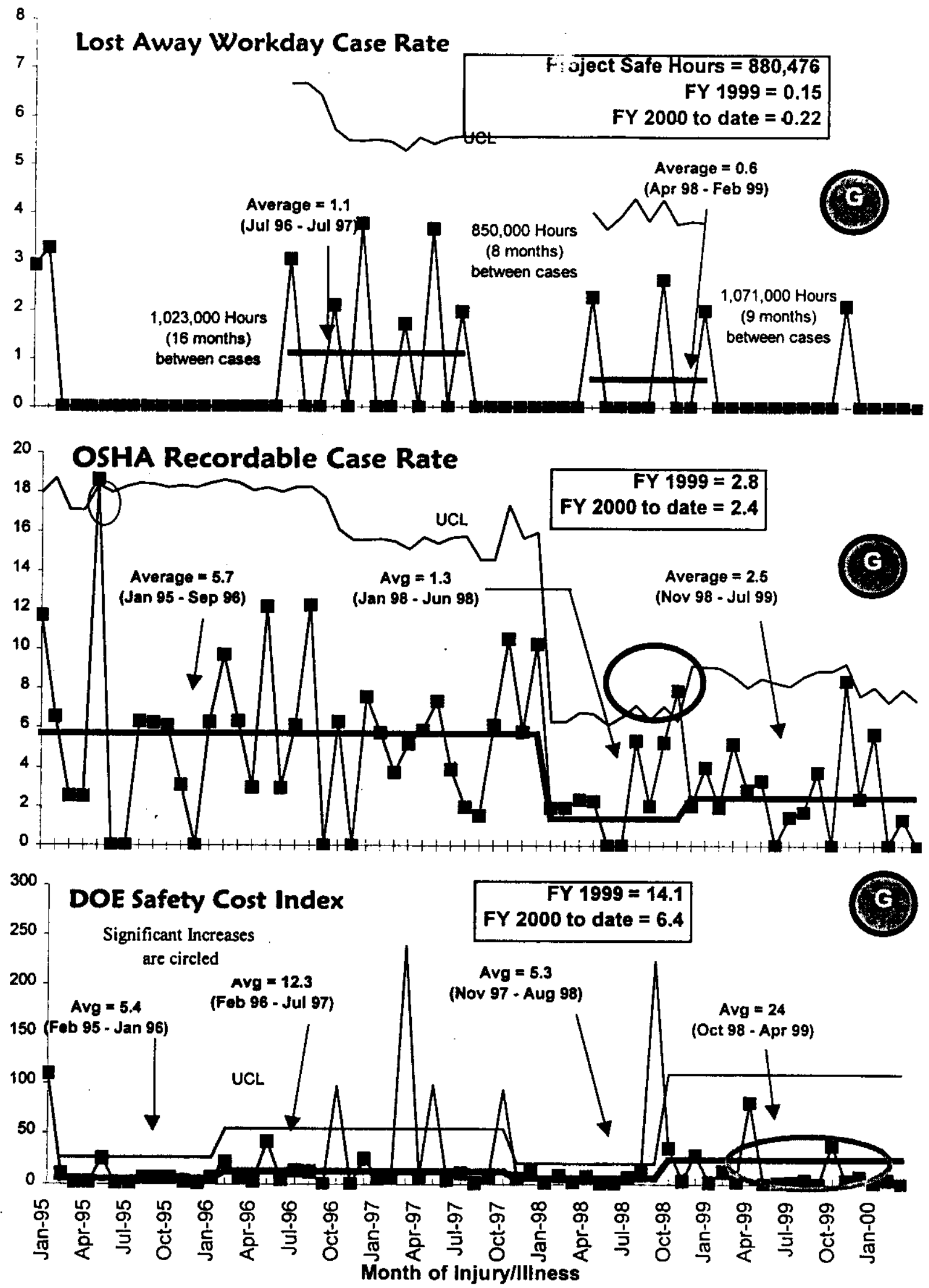


\section{CONDUCT OF OPERATIONS / ISMS STATUS CONDUCT OF OPERATIONS \\ Events per 200,000 hours}

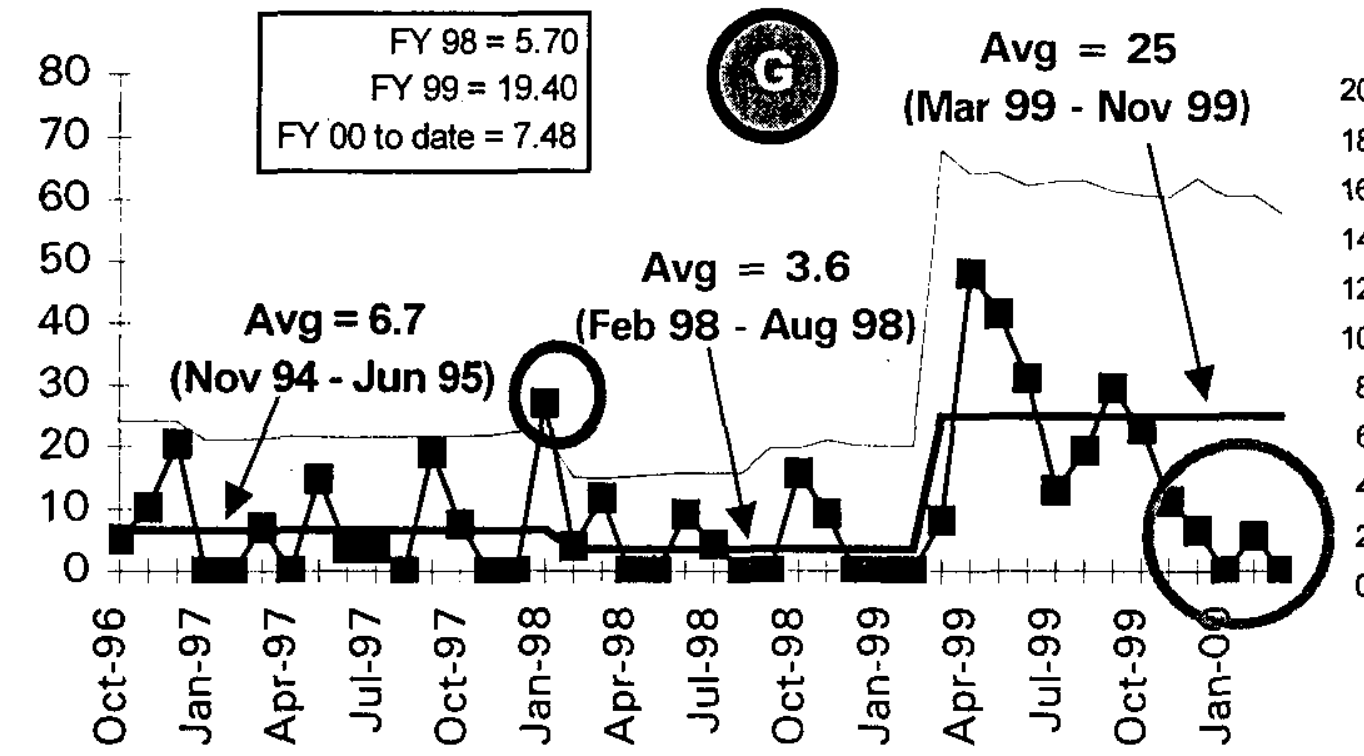

No. of Reports

20. Past 12 Months

\section{ISMS STATUS}

\section{Green}

- $\quad$ The ISMS Phase I/II verification for the SNF Project was completed on November 19, 1999.

- The Corrective Action Plans for the "Opportunities for Improvement" were developed and transmitted to RL on January 10, 2000.

- $\quad$ The actions required to enable ISMS implementation to be declared March 31, 2000 are now complete. Documentation packages are being prepared for transmittal to the Environmental, Safety \& Health organization.

\section{BREAKTHROUGHS / OPPORTUNITIES FOR IMPROVEMENT}

\section{Breakthroughs}

\section{Green}

- Baseline Change Request SNF-2000-009, which proposes a strategy to accelerate the completion of sludge removal by one year from August 2005 to August 2004 and reduce total project life cycle cost by $\$ 16$ million, was approved for Implementation. 


\section{Opportunities for Improvement}

Phased Startup Initiative (PSI) -- Results from the PSI are expected to improve the fuel production rates by approximately one month in FY 2001.

\section{UPCOMING ACTIVITIES}

CVD Facility Testing - Testing at the CVD Facility continues to remain on critical path. Completion of testing is scheduled for the end of May 2000.

Cask Loadout System (CLS) Testing - Complete startup testing by mid-June 2000.

Phased Startup Initiative (PSI) - Complete PSI Phases $1 \& 2$ in order to support start of Phase 3. Complete Phases $3 \& 4$ by mid-August 2000.

Storage Projects - Deliver first shipment of Multi-Canister Overpack baskets by June 1, 2000.

Fuel Removal Activities - Begin DOE Operations Readiness Review by mid-September 2000. Begin K West Basin fuel removal, drying \& storage operations by November 30, 2000.

\section{Cost Performance $(\$ M):$}

\begin{tabular}{|l|c|c|c|}
\hline & BCWP & ACWP & VARIANCE \\
\hline Spent Nuclear Fuel & $\$ 89.4$ & $\$ 104.9$ & $-\$ 15.5$ \\
\hline
\end{tabular}

The unfavorable cost variance of $\$ 15.5$ million (17 percent) is primarily due to engineering, testing, transition and administrative support being underestimated for FY 2000; KW punchlist items not in baseline; and Hanford Site assessments higher than baseline.

\section{SCHedule Performance ( $\$ M)$ :}

\begin{tabular}{|l|c|c|c|}
\hline & BCWP & BCWS & VARIANCE \\
\hline Spent Nuclear Fuel & $\$ 89.4$ & $\$ 91.4$ & $-\$ 2.0$ \\
\hline
\end{tabular}

The unfavorable schedule variance of $\$ 2.0$ million ( 2 percent) is primarily a result of $\mathrm{K}$ East basin work that has been stopped pending approval of the sludge acceleration strategy, upon which the workscope will be deferred to later years. In addition, site-wide spent nuclear fuel work has been stopped as a result of site workscope prioritization. 
Fy 2000 Cost/SChedule PerformanCe - All Fund TyPes Cumulative to Date Status - $(\$ 000)$

FYTD

By PBS

BCWS BCWP ACWP

sv

$\%$

cV

PEM

PBS WM01 Spent Nuclear

WBS 1.3 Fuel Project $\$ 991,382 \quad \$ 89,428 \quad \$ 104,925 \quad \$(1,955)-2 \% \quad \$(15,497)-17 \% \quad \$ 195,073$

Total

$\begin{array}{llllllll}\$ 91,382 & \$ 89,428 & \$ 104,925 & \$(1,955) & -2 \% & \$(15,497) & -17 \% & \$ 195,073\end{array}$

\section{Cost/Schedule Performance Indices (MARCH 2000 AND FYTD)}

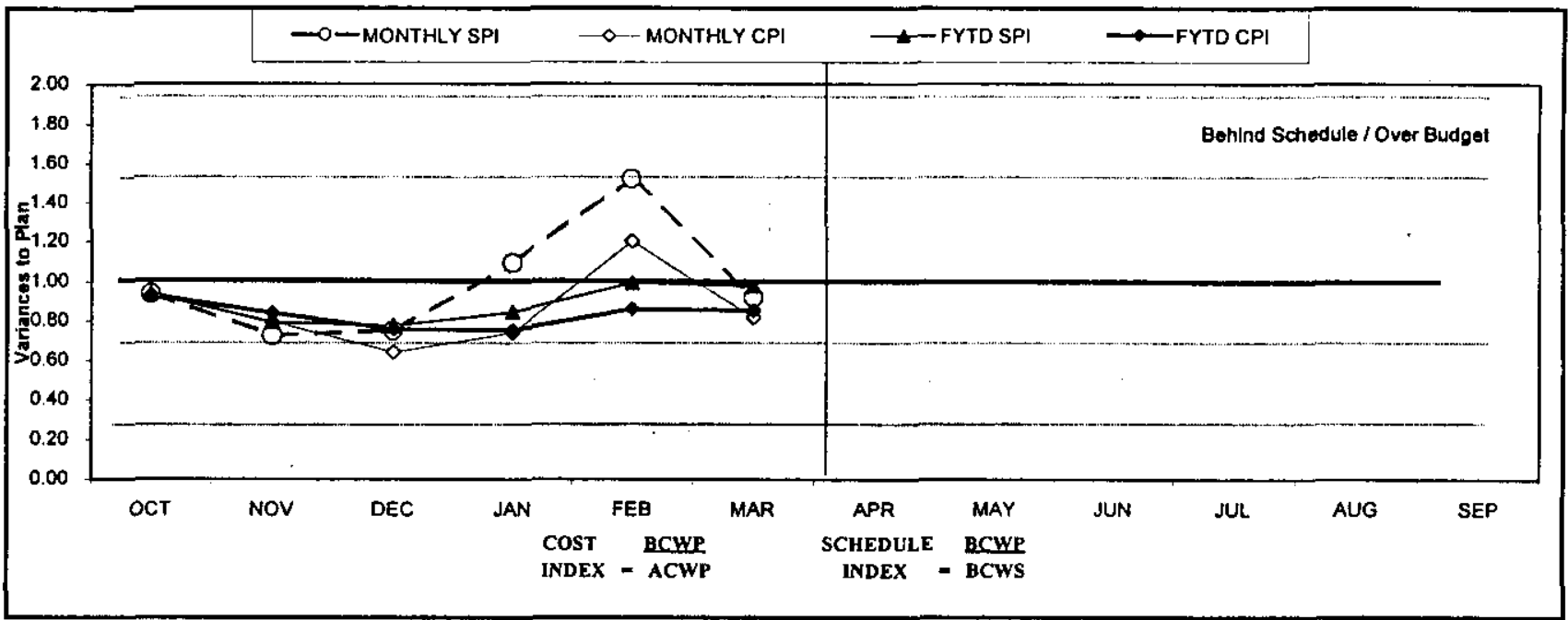

\begin{tabular}{|c|c|c|c|c|c|c|c|c|c|c|c|c|}
\hline FY 2000 & $\mathrm{OCT}$ & NOV & DEC & JAN & FEB & $\overline{\mathrm{MAR}}$ & $\overline{A P R}$ & MIAY & JUN & JUL & AUG & SEP \\
\hline MONTHLY SPI & 0.94 & 073 & 0.73 & 1.09 & 1.52 & 0.92 & & & & & & \\
\hline MONTHLY CPI & 0.93 & 0.79 & 0.64 & 0.74 & 1.20 & 0.82 & & & & & & \\
\hline FYTD SPI & 0.94 & 0.79 & 0.78 & 0.85 & 0.99 & 0.98 & & & & & & \\
\hline FYTD CPI & 0.93 & 0.84 & 0.76 & 0.75 & 0.86 & 0.85 & & & & & & \\
\hline MONTHLY BCWS & 58,574 & 519,209 & 515,681 & $\$ 12,081$ & 515,753 & $\$ 20,085$ & $\$ 16,200$ & 519,684 & 515,440 & S14,073 & 518,415 & $\$ 19,880$ \\
\hline MONTHLY BCWP & 58,049 & 513,968 & 511,770 & $\$ 13,221$ & $\$ 23,909$ & $5|8,5| 1$ & & & & & & \\
\hline MONTHLY ACWP & 58,626 & 517,581 & 518,370 & 517,831 & $\$ 19,906$ & $\$ 22,611$ & & & & & & \\
\hline FYTD BCWS & 58,574 & 527.783 & 543,463 & 555,544 & 571,297 & $\$ 91,382$ & $\mathbf{S 1 0 7 , 5 8 2}$ & $\$ 127,266$ & 5142,706 & $\$ 136,778$ & $\$ 175,193$ & $\$ 195,073$ \\
\hline FYTD BCWP & 58,049 & $\$ 22,016$ & 533,786 & $\$ 47,008$ & 570,917 & 589,428 & & & & & & \\
\hline FYTD ACWP & $\$ 8,626$ & $\$ 26.207$ & $\$ 44,577$ & 562,408 & $\$ 82,314$ & $\$ 104,925$ & & & & & & \\
\hline
\end{tabular}

\section{COST VARIANCE ANALYSIS: ( $\$ 15.5 \mathrm{M})$}

\section{WBS/PBS}

\subsection{1/WM01}

Title

Description/Cause: The unfavorable cost variance of $\$ 15.5 \mathrm{M}(17.0$ percent $)$ is due to engineering, testing, transition and administrative support underestimated for FY $2000(78 \%)$; KW punchlist items not in baseline (13\%); and Hanford Site assessments higher than baseline (9\%).

Impact: These overruns were anticipated changes foreseen during the contingency analysis and will be allocated through change control. Additional unanticipated cost impacts, i.e., rate 
increases, Corrective Action Management, Hanford Security, and fee allocation are likely to have an adverse impact unless outside funding sources are made available. In addition, Change Requests (CRs) have been developed and reviewed and are on hold pending source availability for $\mathrm{KW}$ punchlist items, engineering, testing and administrative support.

Corrective Action: Pursue other Hanford funding to cover site issues and prioritize SNI work within available SNF budget.

\section{SCHEDULE VARIANCE ANALYSIS: ( $\$ 2.0 M)$ WBS/PBS Title}

\subsection{1/ WM01 Spent Nuclear Fuel Project}

Description /Cause: The unfavorable schedule variance of $\$ 2.0 \mathrm{M}(2.2$ percent $)$ is primarily a result of $\mathrm{K}$ East basin work that has been stopped pending approval of the sludge acceleration strategy, upon which the workscope will be deferred to later years (55\%). In addition, site-wide spent nuclear fuel work has been stopped as a result of site workscope prioritization (37\%). Impact: No impact to schedule baseline is anticipated as CR approval and implementation is expected to either defer or eliminate this workscope.

Corrective Action: Approve and implement CRs SNF-2000-009, "Sludge Acceleration Strategy," and SNF-2000-016, "Defer Site-Wide SNF Project Activities to Align with Site Prioritization."

\section{ISSUES}

There are no technical, DOE, Regulator or external issues identified at this time.

\section{Baseline Change Requests Currently in Process (\$000)}

\begin{tabular}{|c|c|c|c|c|c|c|c|c|c|}
\hline $\begin{array}{l}\text { PROJECT } \\
\text { CHANGE } \\
\text { NUMBER }\end{array}$ & $\begin{array}{c}\text { DATE } \\
\text { ORIGIN. }\end{array}$ & BCR TITLE & $\begin{array}{l}\text { FYOO COST } \\
\text { IMPACT } \$ 000\end{array}$ & SCH & TECH & $\begin{array}{l}\text { DATE } \\
\text { TO CCB }\end{array}$ & $\begin{array}{c}\text { CCB } \\
\text { APR'VD }\end{array}$ & $\begin{array}{c}\text { RL } \\
\text { APRVD }\end{array}$ & CURRENT STATUS \\
\hline $\begin{array}{l}\text { SNF-2000-000 } \\
\text { SNF-2000-010 } \\
\text { SNF-2000-013 } \\
\text { SNF-2000-014 } \\
\text { SNF-2000-016 }\end{array}$ & $\begin{array}{l}1 / 31 / 00 \\
1 / 31 / 00 \\
3 / 6 / 00 \\
3 / 20 / 00 \\
3 / 24 / 00\end{array}$ & $\begin{array}{l}\text { Sludge Acceleration Strategy } \\
\text { SNF Prolect FY2000 MYWP } \\
\text { Revised Rate Impacts } \\
\text { Delayed Scope for TGA } \\
\text { Sample Disposal } \\
\text { FY2000 Budget Authority } \\
\text { Increase } \\
\text { Defer Site-Wide SNF Project } \\
\text { Activities to Algn with Site- } \\
\text { Wide Prioritization }\end{array}$ & $\begin{array}{l}\$ 1,300 \\
(\$ 1,300)\end{array}$ & $\begin{array}{l}\mathbf{Y} \\
\mathbf{N} \\
\mathbf{Y} \\
\mathbf{N} \\
\mathbf{Y}\end{array}$ & $\begin{array}{l}\mathbf{Y} \\
\mathbf{N} \\
\mathbf{Y} \\
\mathbf{N} \\
\mathbf{N}\end{array}$ & $2 / 24 / 00$ & $2 / 25 / 00$ & $4 / 7 / 00$ & $\begin{array}{l}\text { Received DOE HO } \\
\text { approval } 4 \pi / 00 . \\
\text { in preparation. } \\
\text { Transmitted to FDH CCA } \\
3 / 28 / 00 \text {. On Hold. } \\
\text { Transmitted to FDH CCA } \\
3 / 28 / 00 \text {. On Hold. } \\
\text { In Project Controls } \\
\text { Review. }\end{array}$ \\
\hline \multicolumn{10}{|c|}{ ADVANCE WORK AUTHORIZATIONS } \\
\hline & & Nothing to report & & & & & & & \\
\hline
\end{tabular}


PHMC Environmental Management Performance Report 4 16 12000

Section D-Spent Nuclear Fuel

\section{SPENT NUCLEAR FUELS - WBS 1.3 MILESTONE ACHIEVEMENT}

\begin{tabular}{|c|c|c|c|c|c|c|c|c|}
\hline \multirow[b]{2}{*}{ MILESTONE TYPE } & \multicolumn{4}{|c|}{ FISCAL YEAR-TO-DATE } & \multicolumn{3}{|c|}{ REMAINING SCHEDULED } & \multirow[b]{2}{*}{\begin{tabular}{|} 
TOTAL \\
FY \\
2000
\end{tabular}} \\
\hline & $\begin{array}{c}\text { Completed } \\
\text { Early }\end{array}$ & $\begin{array}{l}\text { Completed } \\
\text { On } \\
\text { Schedule }\end{array}$ & $\begin{array}{c}\text { Completed } \\
\text { Late }\end{array}$ & Overdue & $\begin{array}{l}\text { Forecast } \\
\text { Early }\end{array}$ & $\begin{array}{c}\text { Forecast } \\
\text { On } \\
\text { Schedule }\end{array}$ & $\begin{array}{c}\text { Forecast } \\
\text { Late }\end{array}$ & \\
\hline Enforceable Agreement & 2 & $\underline{0}$ & 의 & 0 & $\underline{0}$ & 0 & 0 & \\
\hline DOE-HQ & 0 & $\underline{0}$ & 0 & 0 & 0 & 0 & 0 & \\
\hline $\mathrm{RL}$ & 0 & 0 & 0 & 1 & 0 & 3 & $\underline{0}$ & 4 \\
\hline Total Project & 2 & 0 & 0 & 1 & 0 & 3 & 0 & 6 \\
\hline
\end{tabular}

\section{Status as of $4 / 18 / 2000$}

\section{Green}

Tri-Party Agreement / EA Milestones

\begin{tabular}{|l|l|l|}
\hline \multicolumn{1}{|c|}{ Number } & \multicolumn{1}{|c|}{ Milestone Title } & \multicolumn{1}{c|}{ Status } \\
\hline $\begin{array}{l}\text { M-34-14A (S06- } \\
\text { 97-009) }\end{array}$ & $\begin{array}{l}\text { "Complete K West Basin Cask } \\
\text { Facility Modules" }\end{array}$ & $\begin{array}{l}\text { due 2/29/00 - Completed on } \\
\text { schedule }\end{array}$ \\
\hline $\begin{array}{l}\text { M-34-04 (S01- } \\
\text { 99-124), }\end{array}$ & $\begin{array}{l}\text { "Submit Remedial Design } \\
\text { Report/Remedial Action Work } \\
\text { Plan for the K Basins" }\end{array}$ & $\begin{array}{l}\text { due 3/31/00 - Completed over 1 month } \\
\text { early }(2 / 10 / 00) .\end{array}$ \\
\hline M-34-05 (T01) & $\begin{array}{l}\text { "Submit Report on Quantities, } \\
\text { Character, and Management of K } \\
\text { Basins Debris" }\end{array}$ & due 5/31/00 - On schedule \\
\hline $\begin{array}{l}\text { M-34-16 (S00- } \\
\text { 01-900) }\end{array}$ & $\begin{array}{l}\text { "Initiate removal of K West } \\
\text { Basin Spent Nuclear Fuel" }\end{array}$ & due 11/30/00 - On schedule. \\
\hline M-34-06-T01 & $\begin{array}{l}\text { "Initiate K West Basin Spent } \\
\text { Nuclear Fuel Canister Cleaning } \\
\text { Operations" }\end{array}$ & due 12/31/00 - On schedule. \\
\hline
\end{tabular}

DNFSB Commitments

\begin{tabular}{|l|l|l|}
\hline & Nothing to report. & \\
\hline & & \\
\hline
\end{tabular}

\section{MILESTONE EXCEPTION REPORT}

\begin{tabular}{|c|c|c|}
\hline lumber/NWBS Level & Milestone Title & $\begin{array}{l}\text { Baseline } \\
\text { Date }\end{array}$ \\
\hline
\end{tabular}

\section{OVerdue - 1}

S07-97-053 RL CSB FSAR and Project FSAR Approval 03/01/00 04/18/00 1.3.1 
Cause: RL Directed changes to remove conservatism

Impact: None

Corrective Action: Was completed on April 18.

\section{Performance Objectives}

Readiness for Fuel Movement (RC-1-1.a-I) - Contractor completion of construction and operational testing, Management Self-Assessment, and Independent ORR by $9 / 14 / 00$ to begin moving fuel by $11 / 30 / 00$. Start of fuel movement is currently on track for $11 / 30 / 00$.

Phased Startup Initiative (PSI) (RC-1-1.a-II) - Complete PSI Phases $1 \& 2$ by April 15,2000 . This includes successful Cold Testing of IWTS \& FRS. This activity is behind schedule due to required changes to the IWTS Control System Software.

Accelerate Fuel Movement (RC-1SS-1) - Accelerate start of fuel movement by two months. Assumes no problems during first fuel movement and no ORR or MSA discrepancies.

Phased Startup Initiative (PSI) (RC-1SS-2) - Complete Phases $3 \& 4$ by August 15, 2000. This includes completion of FRS/lWTS system testing using SNF (real fuel) and completion of CCD2. This activity is on schedule.
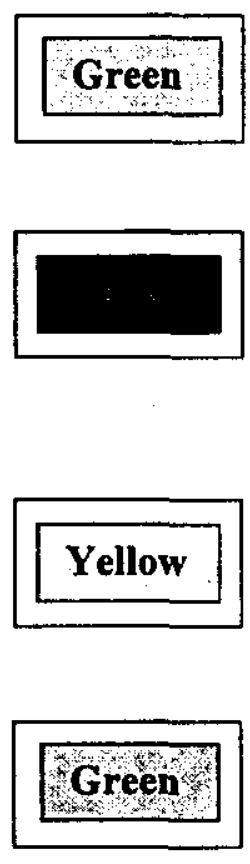

\section{KEY INTEGRATION ACTIVITIES}

- Spent nuclear fuel (SNF) final disposition interface activities, including Office of Civilian Radiation Waste Management (OCRWM) Quality Assurance (QA) Program implementation, ongoing with National SNF Program.

- $\quad$ K Basins sludge removal and Shippingport (PA) Pressurized Water Reactor Core 2 SNF removal implementation activities ongoing with Waste Management Project.

- $\quad 324$ Building (B Cell) SNF removal acceptance criteria and conceptual design reviews ongoing with River Corridor Project.

- $\quad$ Neutron Radiography Facility, Training, Research and Isotope Production, General Atomics (TRIGA), and FFTF SNF relocation planning ongoing with FFTF Project.

- Input provided to BHI on recovery actions required if SNF is discovered during upcoming reactor basins deactivation.

- Completed assessment and documentation for the Canister Storage Building's readiness to support the receipt of Immobilized High Level Waste (IHLW) from ORP. 
PHMC Environmental Management Performance Report-May 2000 Section E-Advanced Reactors Transition Program (ART)
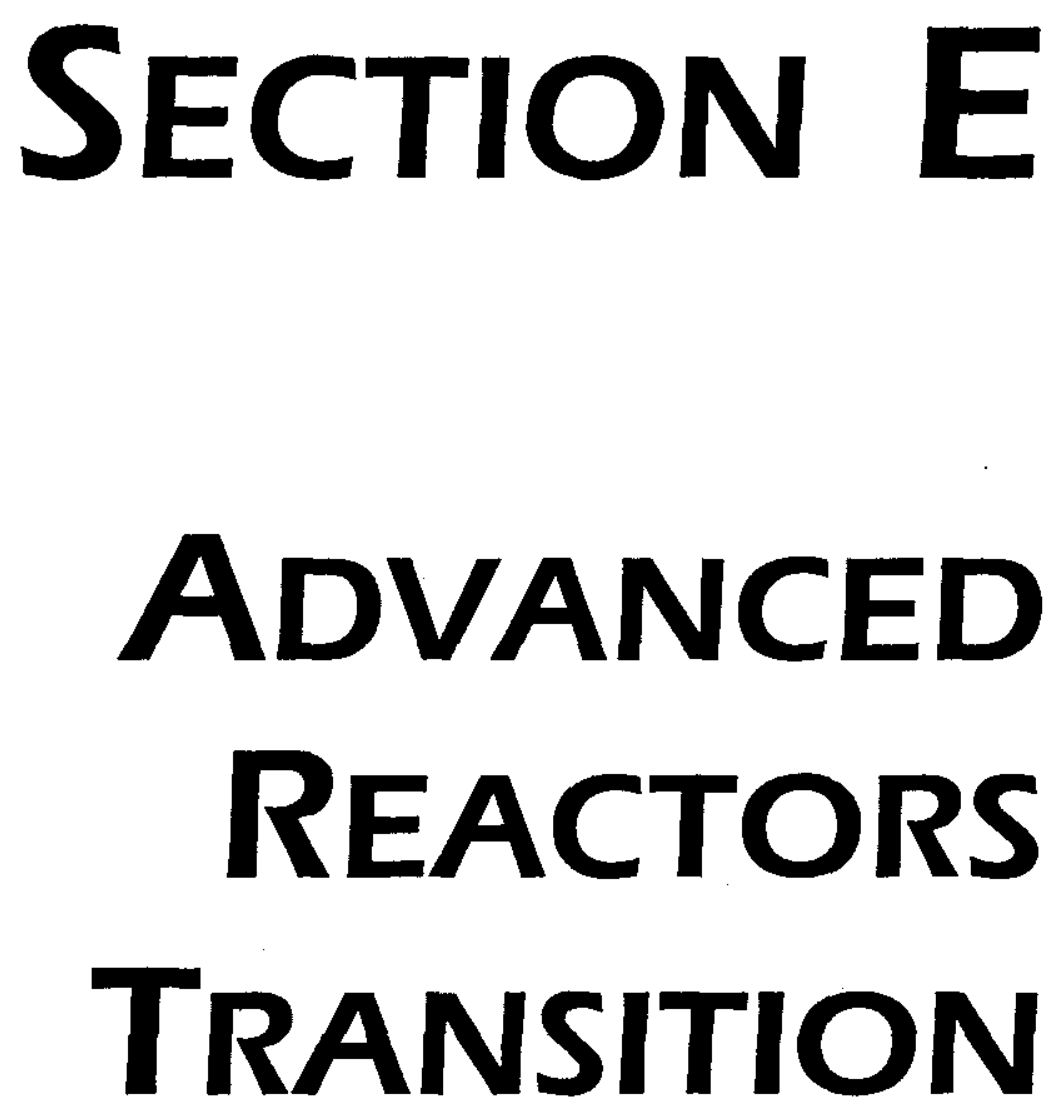

Project Managers

\author{
O. A. Farabee, RL \\ Phone: (509) 376-8089 \\ D. B. Klos, FDH \\ Phone: (509) 373-3574
}




\section{SUMMARY}

The Advanced Reactors Transition (ART) Program, WBS 1.12.1.1, PBS RL-TP1 1, consists of the 309 Building and the Nuclear Energy (NE) Legacies activities.

NOTE: Unless otherwise noted, the Safety, Conduct of Operations, Milestone Achievement, and Cost/Schedule data contained herein is as of March 31, 2000. All other information is as of April $18,2000$.

In March the ART mission area technical accomplishments included continued surveillance and maintenance activities on the 309 Building and NE Legacy facilities. Low pH rinse water from two T-plant tanks cleaning operation was sent to the process sewer. Plans for final rinse of the large T-plant tank were finalized. Eddy-current examination of the NaK cooling loop was completed; showing that very little $\mathrm{NaK}$ remains in the system (the bulk NaK was drained and shipped offsite in 1998). Procedures for obtaining a gas sample from the NaK cooling loop are being developed. Concepts and procedures for connecting a water vapor-nitrogen cleaning system to the loop to react remaining residues are being developed. The $309 \mathrm{Bldg}$. / Plutonium Recycle Test Reactor (PRTR) ion exchange column was stabilized, removed, and shipped for burial.

Fiscal-year-to-date milestone performance (EA, DOE-HQ, and RL) shows that there are no milestones due.

\section{ACCOMPLISHMENTS}

- Continued surveillance and maintenance activities on 309 Building and NE legacies.

- Sent low $\mathrm{pH}$ rinse water from two T-plant tanks cleaning operation to process sewer. Finalized plans for final rinse of large tank.

- $\quad$ Completed eddy-current examination of the NaK cooling loop; showing that very little $\mathrm{NaK}$ remains in the system (the bulk NaK was drained and shipped offsite in 1998). Developing procedures for obtaining a gas sample from loop. Developing concepts and procedures for connecting a water vapor-nitrogen cleaning system to loop to react remaining residues.

- $\quad$ The 309 Bldg. / PRTR ion exchange column was stabilized, removed, and shipped for burial.

\section{SAFETY}

Safety data for ART is included in a separate FFTF report. 


\section{CONDUCT OF OPERATIONS / ISMS STATUS}

\section{CONDUCT OF OPERATIONS}

Conduct of operations data for ART is included in a separate FFTF report.

\section{ISMS STATUS}

Preparations continue for the FH DOE Phase I Verification scheduled for mid April. This review will examine the FH/FFTF ISMS system description and all implementing documents.

\section{BREAKTHROUGHS / OPPORTUNITIES FOR IMPROVEMENT}

No breakthroughs or opportunities for improvement have been identified at this time.

\section{UPCOMING ACTIVITIES}

- $\quad$ Complete the cleaning of sodium residue from T Plant tank TK-3.

- Initiate cleaning of the sodium potassium (Nak) residuals from the 337B Building cold trap cooling loop.

- Initiate general cleanout of lower containment level of the 309 Bldg. / PRTR facility.

\section{Cost Performance $(\$ M):$}

\begin{tabular}{|l|c|c|c|}
\hline & BCWP & ACWP & VARIANCE \\
\hline Advanced Reactors Transition & $\$ 0.6$ & $\$ 0.6$ & $+\$ 0.0$ \\
\hline
\end{tabular}

There is no cost variance.

\section{Schedule Performance (\$M):}

\begin{tabular}{|l|c|c|c|}
\hline & BCWP & BCWS & VARIANCE \\
\hline Advanced Reactors Transition & $\$ 0.6$ & $\$ 0.6$ & $+\$ 0.0$ \\
\hline
\end{tabular}

There is no schedule variance. 


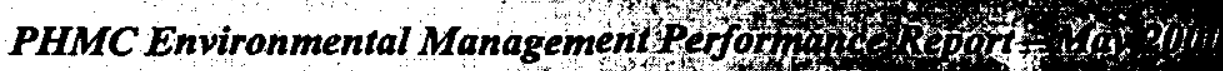

Section E-Advanced Reactors Transition $110 \mathrm{H}$

\section{FY 2000 Cost/Schedule Performance - All Fund Types Cumulative to Date Status - $(\$ 000)$}

FYTD

By PBS

\begin{tabular}{llllllll}
\hline BCWS BCWP ACWP & SV & $\%$ & CV & $\%$ & PEM
\end{tabular}

PBS TP11 Advanced Reactors

WBS 1.12 Transition

\begin{tabular}{llllllllllll}
$\$$ & 627 & $\$$ & 637 & $\$ 601$ & $\$$ & 9 & $1 \%$ & $\$$ & 36 & $6 \%$ & $\$ 1,472$ \\
\hline$\$$ & 627 & $\$$ & 637 & $\$ 601$ & $\$$ & 9 & $1 \%$ & $\$$ & 36 & $6 \%$ & $\$ 1,472$
\end{tabular}

Total

$\begin{array}{llllllllllll} & 627 & \$ & 637 & \$ 601 & \$ & 9 & 1 \% & \$ & 36 & 6 \% & \$ 1,472\end{array}$

\section{COST/SCHEDUle Performance INDices (MARCH 2000 AND FYTD)}

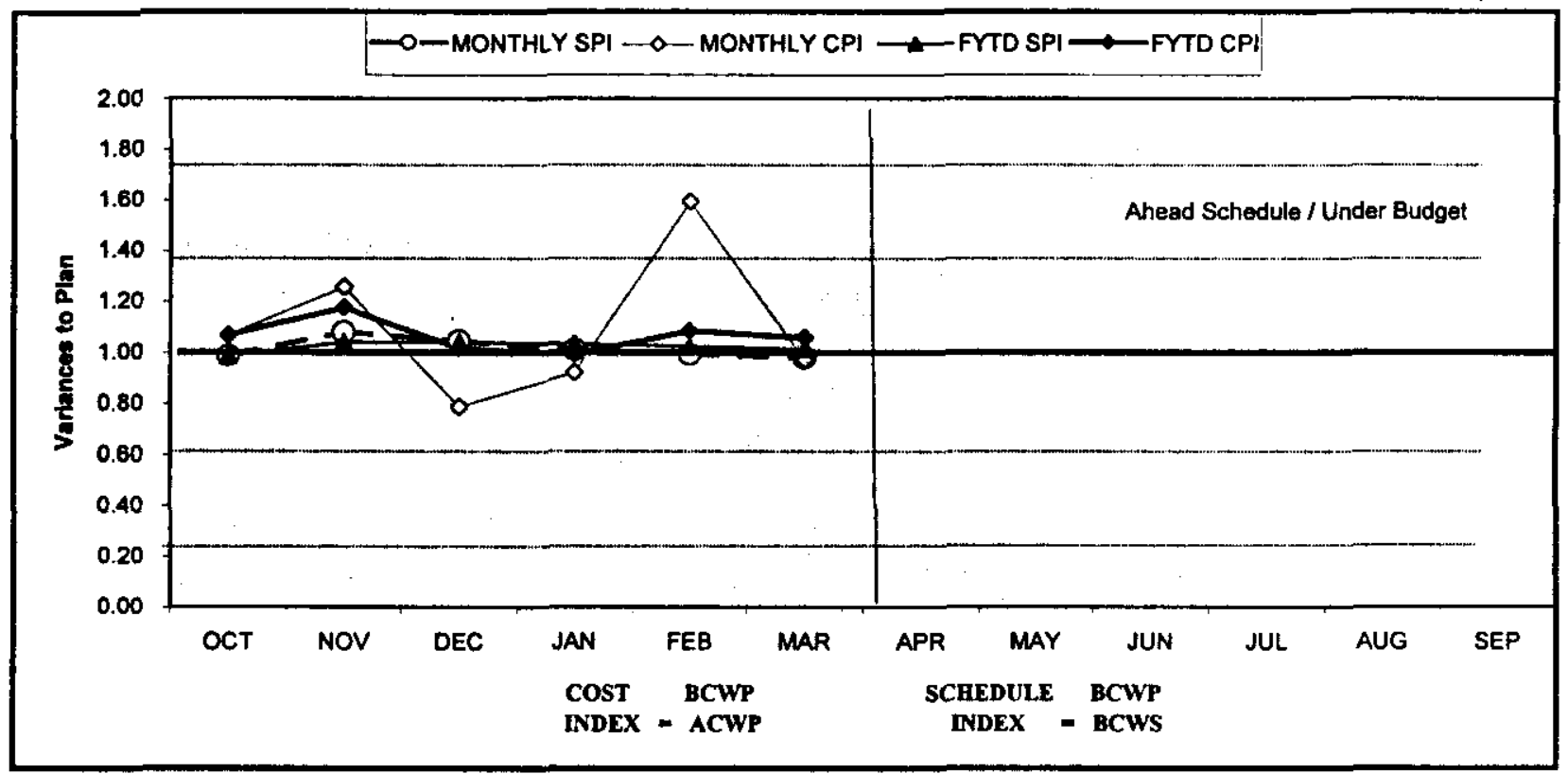

\begin{tabular}{|c|c|c|c|c|c|c|c|c|c|c|c|c|}
\hline FY 2000 & OCT & NOV & DEC & JAN & FEB & MAR & APR & MAY & JUN & JUL & AUG & SEP \\
\hline MONTHLY SPI & 0.99 & 1.08 & 1.05 & 1.01 & 0.98 & 0.98 & & & & & & \\
\hline MONTHLY CPI & 1.07 & 1.28 & 0.79 & $0 . \overline{82}$ & 7.59 & 0.97 & & & & & & \\
\hline FYTO SPI & 0.89 & 1.04 & 1.04 & 1.03 & 1.02 & 1.01 & & & & & & \\
\hline FYTD CPI & 1.07 & 1.18 & 1.02 & 0.99 & 1.05 & 1.06 & & & & & & \\
\hline MONTHLY BCWS & $\$ 78$ & $\$ 113$ & 588 & $\$ 93$ & $\$ 116$ & $\$ 139$ & $\$ 116$ & $\$ 145$ & $\$ 110$ & $\$ 128$ & $\$ 177$ & $\$ 170$ \\
\hline MONTHIY BCWP & $\$ 78$ & $\$ 122$ & $\$ 92$ & $\$ 94$ & $\$ 115$ & $\$ 136$ & & & & & & \\
\hline MONTHLY ACWP & $\$ 73$ & $\$ 87$ & $\$ 117$ & $\$ 102$ & $\$ 72$ & $\$ 140$ & & & & & & \\
\hline FYTD BCWS & $\$ 79$ & $\$ 192$ & $\mathbf{\$ 2 8 0}$ & $\$ 373$ & 3489 & 3627 & $\$ 743$ & $\$ 887$ & $\$ 997$ & $\$ 1.125$ & $\$ 1,302$ & $\$ 1,472$ \\
\hline FYTD BCWP & $\$ 78$ & $\$ 200$ & $\$ 292$ & $\$ 386$ & $\$ 501$ & $\$ 637$ & & & & & & \\
\hline FYTD ACWP & $\$ 73$ & $\$ 170$ & $\$ 287$ & $\$ 389$ & $\$ 461$ & $\$ 601$ & & & & & & \\
\hline
\end{tabular}

\section{ISSUES}

There is nothing to report at this time. 


\section{COST VARIANCE ANALYsIS: $(+\$ 0.0 \mathrm{M})$}

WBS/PBS

1.12/TP11

\section{Title}

Advanced Reactors Transition

Description and Cause: None.

Impact: None.

Corrective Action: None.

\section{SCHEDULE VARIANCE ANALYSIS: $(+\$ 0.0 \mathrm{M})$}

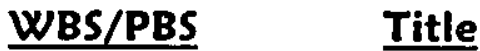

\subsection{2/TP11 Advanced Reactors Transition}

Description and Cause: None.

Impact: None.

Corrective Action: None.

\section{Baseline Change Requests Currently in Process $(\$ 000)$}

\begin{tabular}{|c|c|c|c|c|c|c|c|c|c|}
\hline $\begin{array}{l}\text { PROJECT } \\
\text { CHANGE } \\
\text { NUMBER }\end{array}$ & $\begin{array}{l}\text { DATE } \\
\text { ORIGIN. }\end{array}$ & BCR TTLE & $\begin{array}{l}\text { FYOO COST } \\
\text { IMPACT } \$ 000\end{array}$ & SCH & TECH & $\begin{array}{c}\text { DATE TO } \\
\text { CCB }\end{array}$ & $\begin{array}{c}\text { CCB } \\
\text { APRVD }\end{array}$ & $\begin{array}{c}\mathbf{R L} \\
\text { APRVD }\end{array}$ & $\begin{array}{c}\text { CURRENT } \\
\text { STATUS }\end{array}$ \\
\hline ART-2000-003 & $2 / 11 / 00$ & FY 1999 Carry Over Funds and Scope & 218 & $\mathbf{x}$ & $\mathrm{X}$ & $2 / 12 / 00$ & $2 / 17 / 00$ & $3 / 9 / 00$ & Approved \\
\hline \multicolumn{10}{|c|}{ ADVANCE WORK AUTHORIZATIONS } \\
\hline & & Nothing to report. & & & & & & & \\
\hline
\end{tabular}

\section{MILESTONE ACHIEVEMENT}

\begin{tabular}{|c|c|c|c|c|c|c|c|c|}
\hline \multirow[b]{2}{*}{ MILESTONE TYPE } & \multicolumn{4}{|c|}{ FISCAL YEAR-TO-DATE } & \multicolumn{3}{|c|}{ REMAINING SCHEDULED } & \multirow[b]{2}{*}{$\begin{array}{l}\text { TOTAL } \\
\text { FY } 2000\end{array}$} \\
\hline & $\begin{array}{l}\text { Completed } \\
\text { Early }\end{array}$ & $\begin{array}{c}\text { Completed } \\
\text { On } \\
\text { Schedule }\end{array}$ & $\begin{array}{c}\text { Completed } \\
\text { Late }\end{array}$ & Overdue & $\begin{array}{c}\text { Forecast } \\
\text { Early }\end{array}$ & $\begin{array}{c}\text { Forecast } \\
\text { On } \\
\text { Schedule }\end{array}$ & $\begin{array}{c}\text { Forecast } \\
\text { Late }\end{array}$ & \\
\hline Enforceable Agreement & 0 & 0 & 0 & 0 & $\underline{0}$ & 0 & 0 & 0 \\
\hline DOE-HQ & 0 & $\underline{0}$ & $\underline{0}$ & 0 & $\underline{0}$ & 0 & 0 & 0 \\
\hline $\mathrm{RL}$ & 0 & $\underline{0}$ & 0 & 0 & $\underline{0}$ & 0 & 0 & 0 \\
\hline Total Project & 0 & 0 & 0 & 0 & 0 & 0 & 0 & 0 \\
\hline
\end{tabular}

Fiscal-year-to-date milestone performance (EA, DOE-HQ, and RL) shows that there are no milestones due. 
PHMC Environmental Management Pefformance Report $34,1,000$

Section E-Advanced Reactors Transition (ART)

Tri-Party Agreement / EA Milestones

Nothing to ruport DNFSB Commitments

Nothing to report.

\section{MiLESTONE EXCEPTION REPORT}

Number/WBS Level

Milestone Title

Baseline

Forecast

OVERDUE - 0

\section{FORECAST LATE - 0}

\section{Performance Objectives}

Nothing to report at this time.

\section{KeY INTEGRATION ACTIVITIES}

Nothing to report at this time. 
PHMC Environmental Management Performance Report-May 2000

Section F-EM - 50
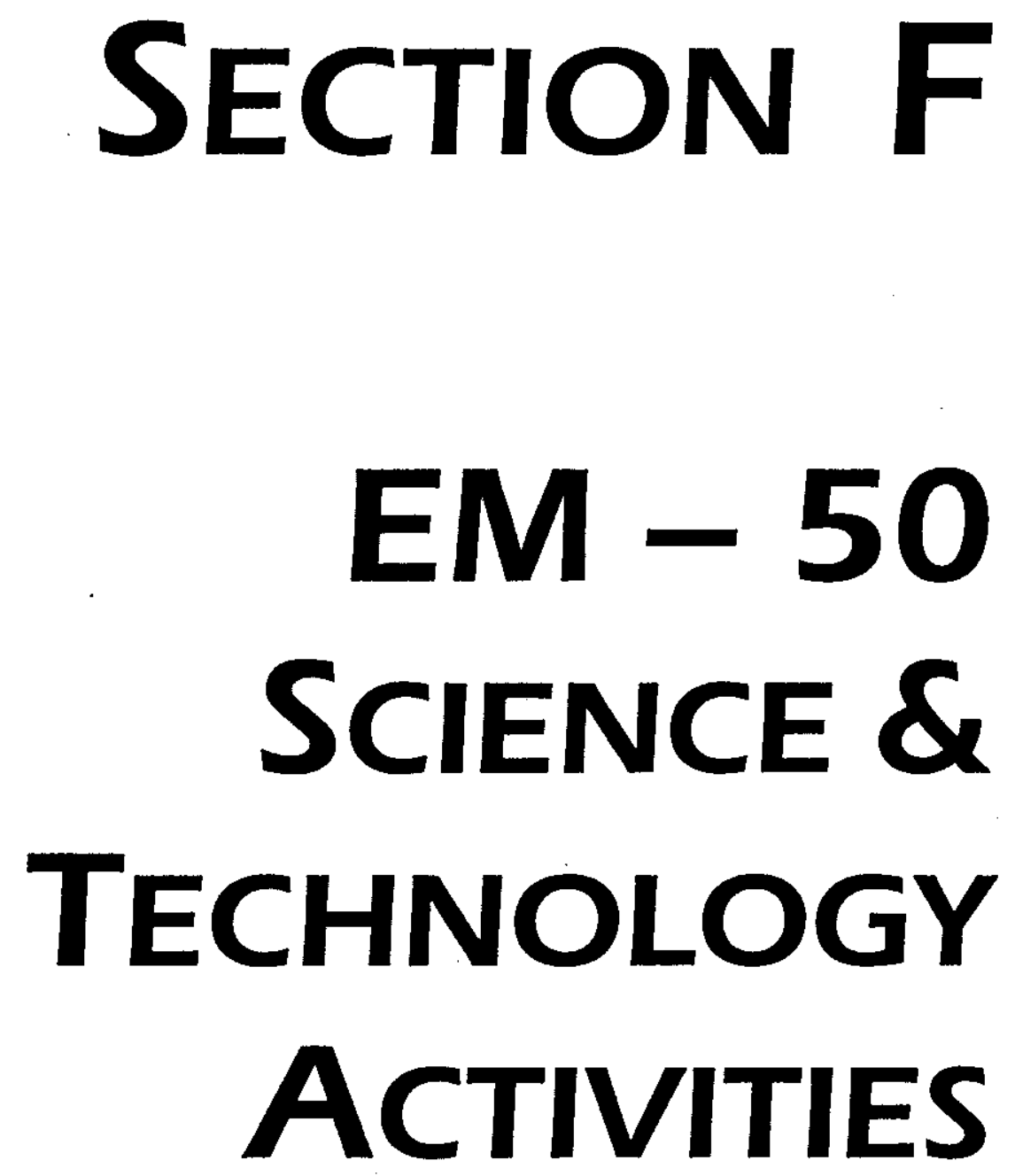


\section{EM-50 Milestone ACHiEvement}

\begin{tabular}{|c|c|c|c|c|c|c|c|c|}
\hline \multirow[b]{2}{*}{ MILESTONE TYPE } & \multicolumn{4}{|c|}{ FISCAL YEAR-TO-DATE } & \multicolumn{3}{|c|}{ REMAINING SCHEDULED } & \multirow[b]{2}{*}{$\begin{array}{l}\text { TOTAL } \\
\text { FY } 2000\end{array}$} \\
\hline & Completed Early & $\begin{array}{l}\text { Completed On } \\
\text { Schedule }\end{array}$ & $\begin{array}{c}\text { Completed } \\
\text { Late }\end{array}$ & Overdue & $\begin{array}{l}\text { Forecast } \\
\text { Early }\end{array}$ & $\begin{array}{l}\text { Forecast } \\
\text { On } \\
\text { Schedule }\end{array}$ & $\begin{array}{c}\text { Forecast } \\
\text { Late }\end{array}$ & \\
\hline Enforceable Agreement & 0 & 0 & $\bar{c}$ & 0 & $\overline{0}$ & $\overline{0}$ & $\bar{c}$ & $\overline{0}$ \\
\hline DOE-HQ & 0 & 0 & $\tau$ & 0 & 0 & 1 & c & 7 \\
\hline RL & 0 & 0 & 1 & 2 & 0 & 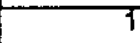 & c & 4 \\
\hline Total Project & 0 & 0 & 1 & 2 & $\overline{0}$ & 2 & 0 & 5 \\
\hline
\end{tabular}

\section{EM-50 EXCEPTIONS}

Number Level Milestone Title Date Date

\section{OVERDUE - 2}

49MW21/C-2 RL Produce Report Mapping the Matrix Space 11/15/99 Proposed 2.1.1 (AMT) in Hanford Waste Boxes

Cause: Activities at WRAP were focused on preparing shipments to WIPP.

Impact: None

Corrective Action: Funding for this TTP was returned to the Mixed Waste Focus Area. This task is cancelled.
49MW21/B-4 RL
Issue Software Test Reports
$12 / 01 / 99$
Proposed
2.1.1 (AMT)
in Hanford Waste Boxes
Deletion

Cause: Activities at WRAP were focused on preparing shipments to WIPP.

Impact: None

Corrective Action: Funding for this TTP was returned to the Mixed Waste Focus Area. This task is cancelled. 
Yanford cleanup activities develop assets - people, experience, land, buildings, research and Itraining facilities - that can have a positive affect on our future. They can help solve national and global problems in food production, global warming, pollution and nuclear nonproliferation. The prime contractors and subcontractors at Hanford are implementing economic development initiatives aimed at weaning the Tri-Cities from dependence on federal cleanup dollars. These initiatives are being supported with grants and by freeing up valuable site resources for use by the private sector. Examples of these initiatives are a new industrial building to attract new businesses to the area, job-creation efforts, and providing technical assistance to entrepreneurs. The Volpentest HAMMER Training and Education Center is included in this outcome. HAMMER provides training for the Hanford Site cleanup mission and the DOE complex. The Center also augments economic diversification by creating a state-of-the-art regional training industry for students from across the nation and around the world. 
PHMC Environmental Management Performance Report-May 2000

Section G-Hammer
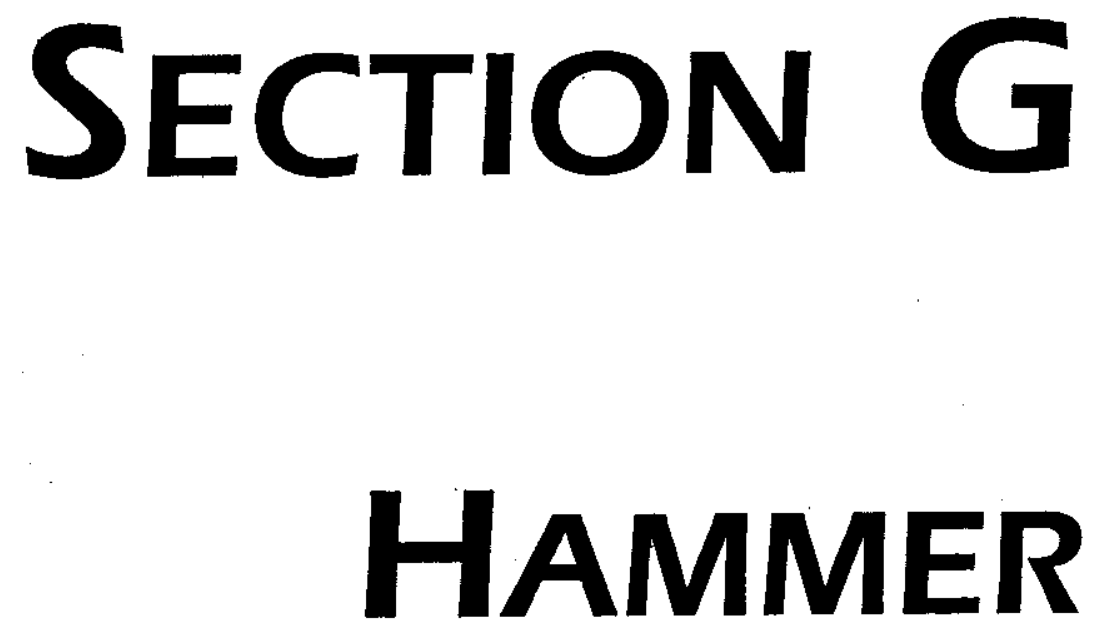

PROGRAM MANAGERS

\author{
J. E. Ollero, RL \\ Phone: (509) 376-3825
}

K. A. McGinnis, FH
Phone: (509) 376-9403 


\section{SUMMARY}

The Hazardous Materials Management and Emergency Response (HAMMER) mission area consists of the HAMMER project, WBS 1.9.1.1, Project Baseline Summary (PBS) HM01.

NOTE: Unless otherwise noted, the Safety, Conduct of Operations, Milestone Achievement, and Cost/Schedule data contained herein is as of the end of March 2000. All other information is as of April 21, 2000.

Volpentest HAMMER's first priority is to deliver hands-on training to the Hanford workforce. During March one hundred seventy-nine classes were conducted at the Volpentest HAMMER facility, for a total of 2,440 Hanford site student days. Highest attended health and safety classes included Hazardous Waste Operations, Respiratory Protection, Radiation Worker II Requalification, Basic Medic First Aid and Fire Extinguisher Training. Overall satisfaction, rated on a scale of 1 to 5 based on level one evaluations, for the month of March: Course Content 4.56, Instructor(s) 4.67, and Facility 4.59.

In a March 15, 2000 ceremony at the Volpentest HAMMER Training and Education Center, the U.S. Department of Labor, OSHA (Occupational Safety and Health Administration) and the U.S. Department of Energy formally celebrated their new partnership. This interdepartmental cooperation exemplifies a Reinventing Government initiative designed to save money by leveraging resources. The partnership will bring effective, rigorous, performance-based training programs (formerly offered only at the OSHA Training Institute in Des Plaines, Illinois) to the Tri-Cities region. HAMMER will also provide training in certain job areas not available at other locations-Electrical Power Generation and Distribution, for example. All courses will positively impact our nations' workers and the compliance officers assigned to protect that workforce.

Non-DOE customers utilizing the Volpentest HAMMER facility for training activities, via the established HAMMER User Agreement process, included OSHA - Office of Training and Education, Energy Northwest, Holmes \& Narver, Bonneville Power Association, City of Nez Perce, WA State Criminal Justice Training Commission, Douglas County Sheriff, and the US District Court-Probation. These training activities generated approximately $\$ 8,500$ of revenue for HAMMER. Generating revenue is included in the FY 2000 MYWP workscope activities for HAMMER, and will assist in reducing costs to DOE of providing site training.

Fiscal-year-to-date milestone performance (EA, DOE-HQ and RL) shows that one of one milestones (100 percent) was completed on or ahead of schedule this reporting period.

\section{ACCOMPLISHMENTS}

- $\quad$ Trained 2,440 Hanford site student days at HAMMER.

- Established new interdepartmental partnership. 
- $\quad$ Eight non-DOE customers utilized the Volpentest HAMMER facility for training activities.

HAMMER currently has no status to report in the areas of ISMS Status, Breakthroughs and Opportunities for Improvement.

\section{UPCOMING ACTIVITIES}

- The first FY 2000 Foreign Border Enforcement Training course will be presented to Moldova students April 25 - May 4, 2000.

- $\quad$ The second Foreign Border Enforcement Training course will be presented in June 2000.

- The Fire Operations Product Line will be developing programs that employ HAMMER props to train individuals who must meet new technical rescue standards.

- The Fire Operations Product Line is working with the U. S. Forest Service to establish training plans for fire fighters that rappel from helicopters. The rappelling course may involve construction of a new prop that could be used for other types of training - SWAT responders and military customers, for instance.

- $\quad$ HAMMER continues to work with the Criminal Justice Training Commission and Washington State Tactical Officer's Association to develop a Basic SWAT School to be held at HAMMER April 30 - May 5, 2000.

\section{Cost Performance (\$M):}

\begin{tabular}{|l|c|c|c|}
\hline & BCWP & ACWP & VARIANCE \\
\hline HAMMER & $\$ 3.0$ & $\$ 2.7$ & $\$ 0.4^{*}$ \\
\hline
\end{tabular}

* Rounding

The $\$ 0.4$ million (12\%) favorable cost variance is due to several factors. Further information at the PBS level can be found in the following Cost Variance Analysis details.

\section{Schedule Performance (\$M):}

\begin{tabular}{|l|c|c|c|}
\hline & BCWP & BCWS & VARIANCE \\
\hline HAMMER & $\$ 3.0$ & $\$ 3.0$ & $\$ 0.0$ \\
\hline
\end{tabular}

The schedule variance is insignificant. 


\section{FY 2000 COSt/SChedule PeRformanCE - All Fund TYPES Cumulative to Date Status - $(\$ 000)$ \\ FYTD}

PBS HM01

\begin{tabular}{llllllll}
\hline BCWS BCWP ACWP SV & $\%$ & CV & $\%$ & PEM
\end{tabular}

WBS 1.9.1 Hammer

$\begin{array}{lllllllllll}\$ 3,027 & \$ 3,027 & \$ 2,656 & \$(0) & 0 \% & \$ 371 & 12 \% & \$ 6,193\end{array}$

Total $\quad \begin{array}{llllllllll}\$ 3,027 & \$ 3,027 & \$ 2,656 & \$(0) & 0 \% & \$ 371 & 12 \% & \$ 6,193\end{array}$

\section{COSt/SChedule Performance INDICES (MARCH 2000 AND FYTD)}

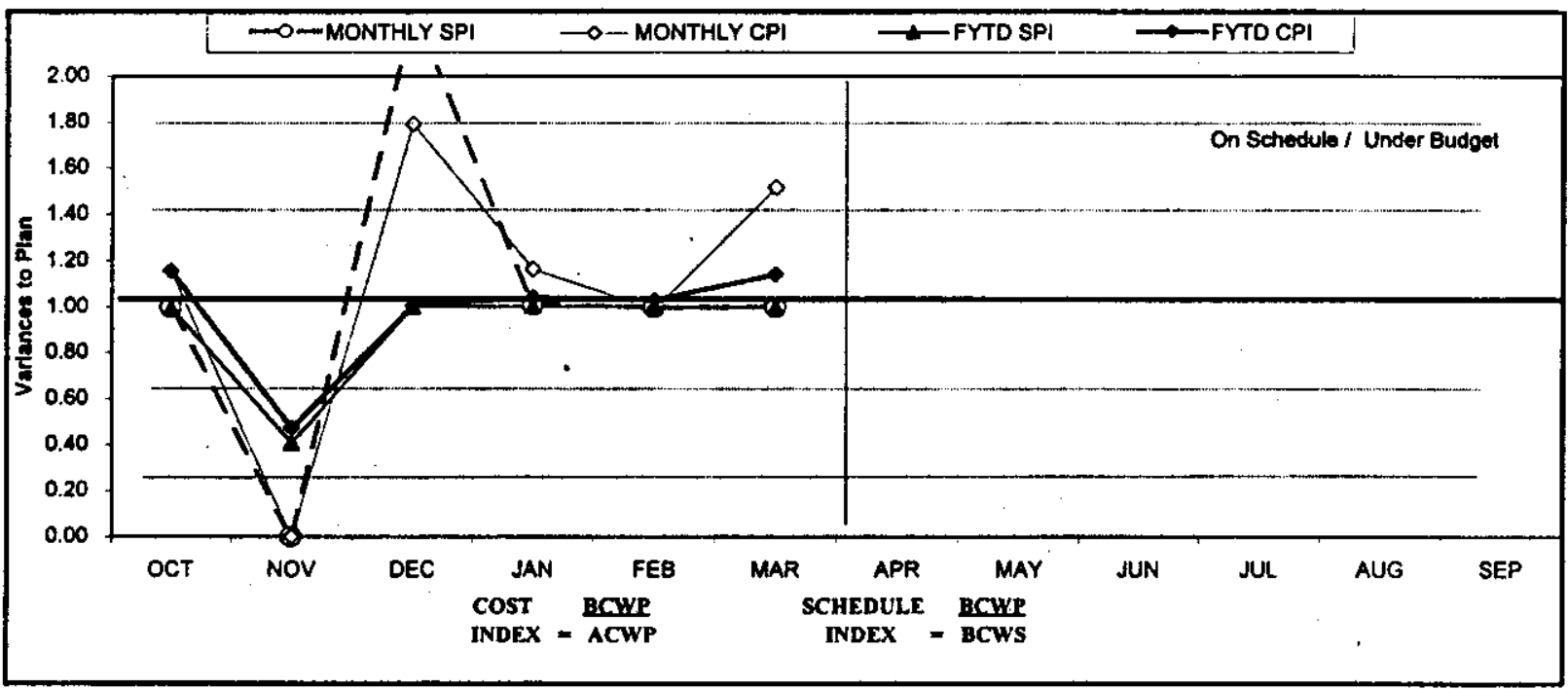

\begin{tabular}{|c|c|c|c|c|c|c|c|c|c|c|c|c|}
\hline FY 2000 & OCT & Nov & DEC & JAN & FEB & MAR & $\mathbf{A P R}$ & MAY & JUN & JUL & AUG & SEP \\
\hline MONTHLY SPI & 0.99 & 0.00 & 2.28 & 1.01 & 1.00 & 1.00 & & & & & & \\
\hline MONTHLYCPI & 1,16 & 0.00 & 1.79 & 1.16 & 0.99 & 1.51 & & & & & & \\
\hline FYTDSPI & 0.99 & 0.41 & 1.00 & 1.00 & 1.00 & 1.00 & & & & & & \\
\hline FYTD CPI & 1.16 & 0.47 & 1.01 & 1.04 & 1.03 & 1.14 & & & & & & \\
\hline MONTHLY BCWS & \begin{tabular}{|ll}
5 & 352 \\
\end{tabular} & \begin{tabular}{|l|l|}
5 & 507 \\
\end{tabular} & $3 \%$ & 418 & 440 & 914 & 528 & 589 & 447 & 447 & 589 & 565 \\
\hline MONTHLY BCWP & 5350 & 5 & 904 & 422 & 438 & 913 & & & & & & \\
\hline MONTHLY ACWP & $5 \quad 303$ & $\$ \quad 439$ & 505 & 363 & 443 & 603 & & & & & & \\
\hline FYTD BCWS & \begin{tabular}{|l|l}
5 & 352 \\
\end{tabular} & \begin{tabular}{|ll}
5 & 859 \\
\end{tabular} & 1,255 & 1,673 & S 2,113 & 3,027 & $5 \quad 3,555$ & S 4,144 & 4,591 & 5,039 & $5 \quad 5,628$ & $5 \quad 6.193$ \\
\hline FYTD BCWP & 5350 & $5 \quad 350$ & 1.254 & 1,676 & $\begin{array}{ll}5 & 2,114 \\
\end{array}$ & 3,027 & & & & & & \\
\hline FYTD ACW? & \begin{tabular}{|l|l|}
$\mathbf{S}$ & 303 \\
\end{tabular} & \begin{tabular}{|ll}
542 \\
\end{tabular} & 1.247 & 1,610 & 2,053 & 2,656 & & & & & & \\
\hline
\end{tabular}

\section{COST VARIANCE ANALYSIS: $(\$ 0.4 \mathrm{M})$}

\section{WBS/PBS TITLE}

\subsubsection{1/HM01 HAMMER}

Description and Cause: The $\$ 0.4$ million (12\%) favorable cost variance is due to a combination of the following items: lag in purchase order contract placement, efficiencies realized through 
staff vacancies and other resources, costed over plan fee (from $90 \%$ to $100 \%$ ), and telephone and computer assessments.

Impact: Minimal.

Corrective Action: Purchase order contracts will be reviewed to identify what is causing the delay, and current efficiencies will be utilized to offset current overrun to fee and as̀sessments.

\section{SCHEDULe VARIANCE ANALYSIS: (\$0.0M)}

\section{$\underline{\text { WBS }} \quad \underline{\text { TITLE }}$}

\subsubsection{1/HM01 HAMMER}

Description and Cause: There is no variance.

Impact: None.

Corrective Action: None.

\section{ISSUES}

Nothing to report at this time.

\section{Baseline Change Requests Currently in Process (\$000)}

\begin{tabular}{|l|c|c|c|c|c|c|c|c|c|}
\hline $\begin{array}{c}\text { PROJECT } \\
\text { CHANGE } \\
\text { NUMBER }\end{array}$ & $\begin{array}{c}\text { DATE } \\
\text { ORIGIN. }\end{array}$ & BCR TITLE & $\begin{array}{c}\text { FYOO COST } \\
\text { IMPACT } \$ 000\end{array}$ & SCH & TECH & $\begin{array}{c}\text { DATE } \\
\text { TO CCB }\end{array}$ & $\begin{array}{c}\text { CCB } \\
\text { APRVD }\end{array}$ & $\begin{array}{c}\text { RL } \\
\text { APRVD }\end{array}$ & $\begin{array}{c}\text { CURRENT } \\
\text { STATUS }\end{array}$ \\
\hline & & Nothing to report. & & & & & & & \\
\hline \multicolumn{7}{|c|}{ ADVANCEWORK AUTHORIZATIONS } \\
\hline
\end{tabular}

\section{MiLestone ACHIEVEMENT}

\begin{tabular}{|c|c|c|c|c|c|c|c|c|}
\hline \multirow[b]{2}{*}{ MILESTONE TYPE } & \multicolumn{4}{|c|}{ FISCAL YEAR-TO-DATE } & \multicolumn{3}{|c|}{ REMAINING SCHEDULED } & \multirow[b]{2}{*}{$\begin{array}{l}\text { TOTAL } \\
\text { FY } 2000\end{array}$} \\
\hline & $\begin{array}{c}\text { Completed } \\
\text { Early }\end{array}$ & $\begin{array}{c}\text { Completed } \\
\text { On Schedule }\end{array}$ & $\begin{array}{c}\text { Completed } \\
\text { Late }\end{array}$ & Overdue & $\begin{array}{l}\text { Forecast } \\
\text { Early }\end{array}$ & $\begin{array}{c}\text { Forecast On } \\
\text { Schedule }\end{array}$ & $\begin{array}{c}\text { Forecast } \\
\text { Late }\end{array}$ & \\
\hline Enforceable Agreement & 0 & 0 & 0 & 0 & 0 & 0 & 0 & 0 \\
\hline DOE-HQ & 0 & 0 & 0 & 0 & 0 & $\underline{0}$ & 0 & 0 \\
\hline $\mathrm{RL}$ & 1 & 0 & 0 & 0 & 0 & 4 & $\underline{0}$ & 5 \\
\hline Total Project & 1 & 0 & 0 & 0 & 0 & 4 & 0 & 5 \\
\hline
\end{tabular}

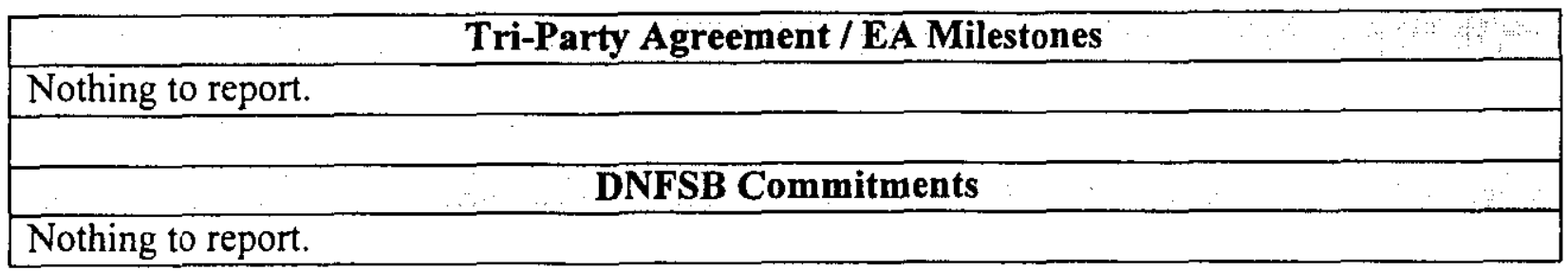


PHMC Environmental Management Performance Report $-M a y, 2000$

Section $G$ - HAMMER

\section{MILESTONE EXCEPTION REPORT}

Number/WBS Level Milestone Title

Baseline

Forecast

Date

Date

Overdue - 0

ForeCAST LATE - 0 


\section{MUltiple}

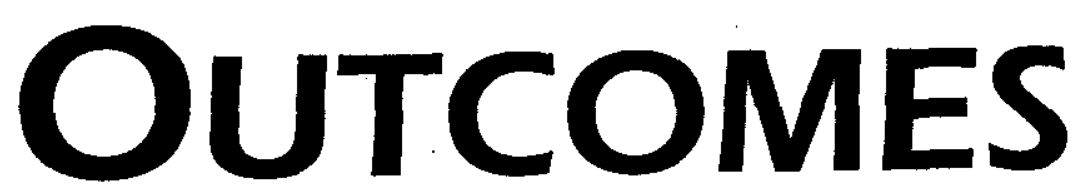

Projects that bridge more than one outcome are included here. These projects include

Pandlord, Support, and National Programs. Further descriptions are included in each section. 

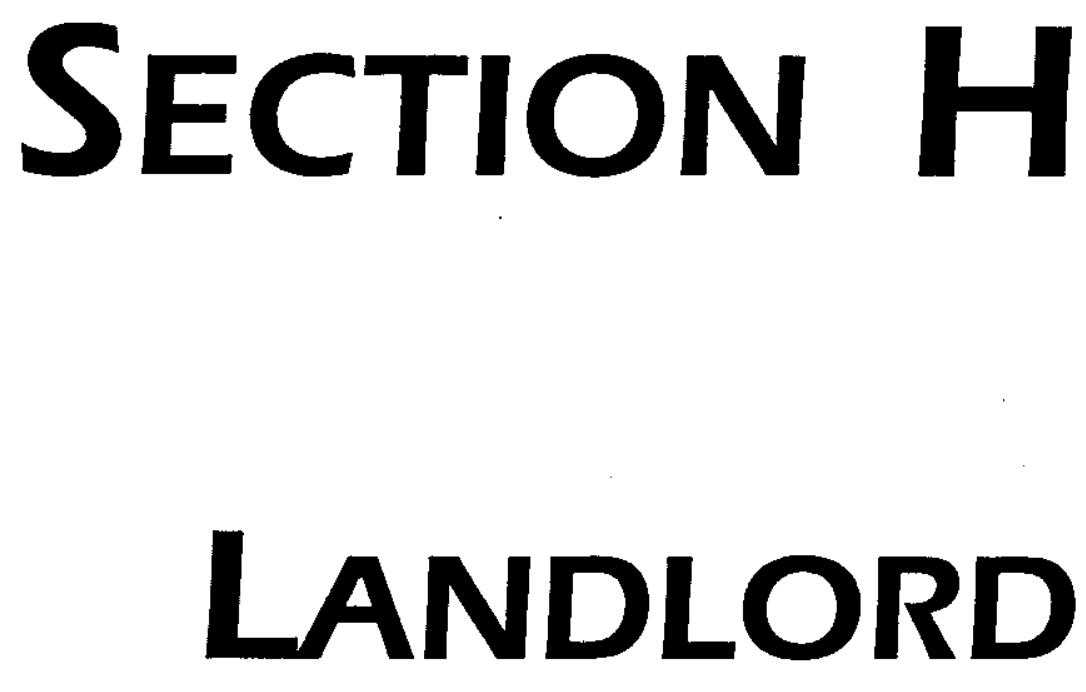

PROJECT MANAGERS

\author{
S. H. Wisness, RL \\ Phone: (509) 373-9337 \\ D. S. Kelly, FH \\ Phone: (509) 376-7334
}




\section{SUMMARY}

The Landlord mission area consists of the Landlord Project, WBS 1.5.1, Project Baseline Summary (PBS) RL-TP13.

NOTE: Unless otherwise noted, the Safety, Conduct of Operations, Milestone Achievement, and Cost/Schedule data contained herein is as of March 31,2000. All other information is as of April 26, 2000.

Radiological surveys of PX railcars continue as part of the Equipment Dispositioning Project. The nuclear licenses for the well car-recycling vendor are being reviewed by DynCorp Radiological Controls in preparation for shipment of the well car.

Final preparations were made for removal of asbestos, a fire hydrant, steam line poles, and foreign material in the French Drain from the Bunker Tanks site in 300 Area. Fieldwork is expected to commence the week of April 17. The 384 Powerhouse Day-Tanks Remediation Report was completed and transmitted to RL for subsequent submittal to Ecology.

Planning and scheduling of initial actions to clean a well drilling slab yard was started as part of the legacy site cleanup activities. NEPA documentation was completed and tumbleweeds were removed to provide access to materials at the site.

Reclassification forms and general descriptions were completed for the Waste Information Data System (WIDS) sites that are proposed to be used as inert and demolition landfills for the powerhouses in 200 East and 200 West. In conjunction with this activity, waste determinations for coal were obtained and regulatory requirements for reclassification of such sites were researched. RL has signed the reclassification form. The final step is to obtain regulator concurrence.

Fiscal-year-to-date milestone performance (EA, DOE-HQ, Field Office, and RL) shows one milestone overdue for completion of Definitive Design for Project L-314, "Law Enforcement and Security Training Center Renovations". A Baseline Change Request is in process to delete this milestone. Workscope has been deferred due to funding reductions directed by RL.

\section{ACCOMPLISHMENTS}

Definitive Design for Project L-312, “2101M and MO-235 and Associated Facilities Storm Drainage Resolution," was issued for construction. The construction bid package has been prepared and fixed price construction bids were received on April 13, 2000.

\section{SAFETY}

FY 1999 performance was stable for case rates, but was very unstable in terms of severity (days away and restricted). FY 2000 appears to have been stable. Safety Cost Index has been moved 
to Green, as it appears that the current data are stable at a good rate. Also, OSHA recordable case rate has been below average for 6 months in a row. If next month is also below average, that will be a significant improving trend.
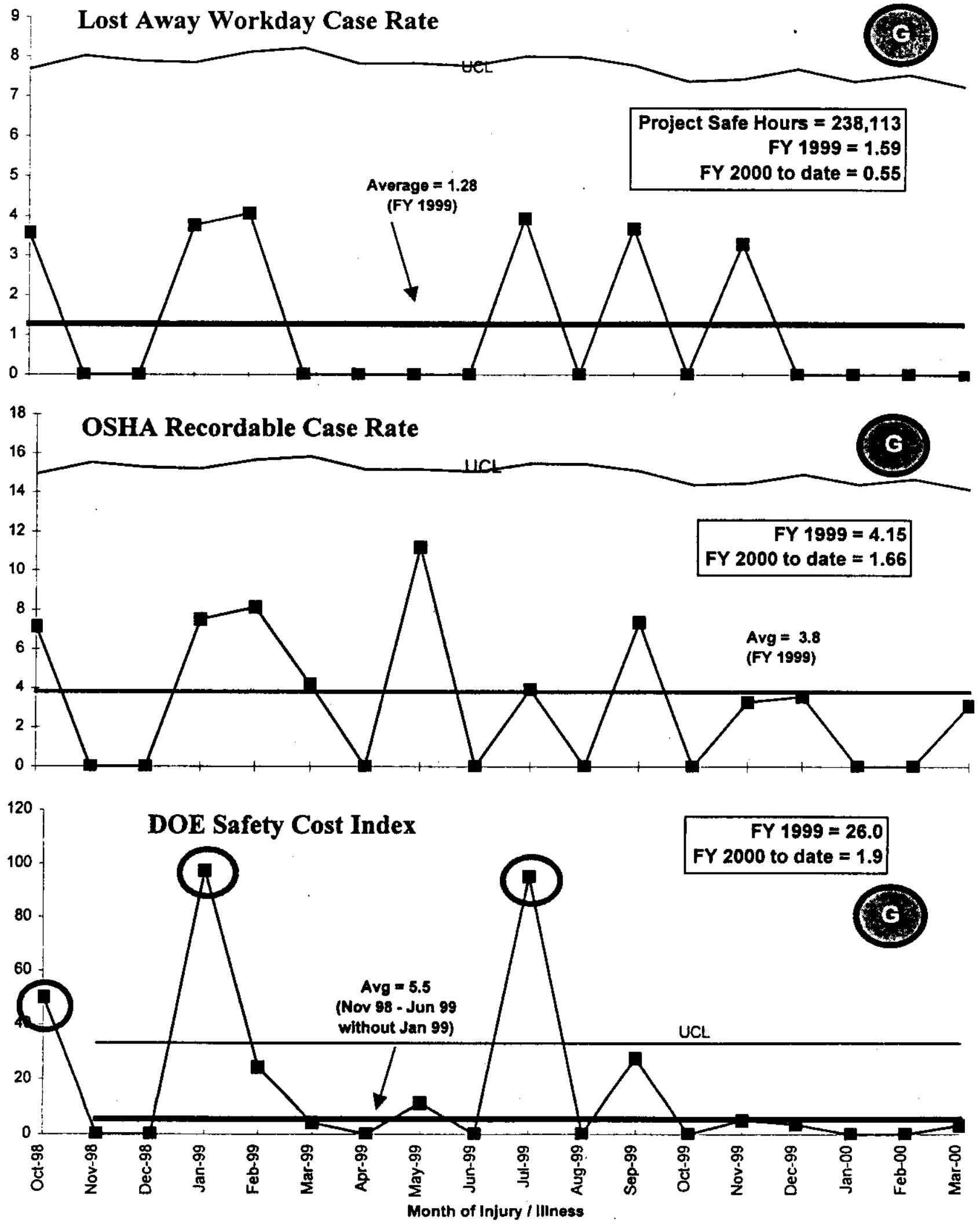


\section{ISMS Status}

Green

- Continue to resolve the 16 concerns identified in DynCorp's ISMS Verification report. All 16 items are on schedule to be completed by July 1, 2000.

\section{BREAKTHROUGHS / OPPORTUNITIES FOR IMPROVEMENT}

\section{Breakthroughs}

- $\quad$ Nothing to report at this time.

\section{Opportunities for Improvement}

- A new "fit-for-mission" philosophy that provides visibility and priority to Landlord Project budget requirements is required. This philosophy supports mission requirements as compared to past "run-to-failure" practices and aligns with current risk management practices and RL's three critical outcomes. Efforts are being made to communicate these funding requirements across the site and the project continues to work with the operations to incorporate the necessary infrastructure upgrade projects into the baseline to address the aging infrastructure systems.

\section{UPCOMING ACTIVITIES}

- Complete Definitive Design for Project L-309, "Replace Portion of Main Water Lines," which replaces approximately 1,500 feet of the sanitary water lines in 200 East Area that is inadequate to support the 241-AP Tank Farm facilities by April 28, 2000. This section of piping installed in 1982 as a temporary line is beyond its design life and cannot support the facility's needs.

- $\quad$ Complete final Project Priority List for fiscal years 2001, 2002, and 2003 by May 17, 2000. The finalized PPL supports the development of the Landlord Project FY 2001 Multi-Year Work Plan.

- Complete Definitive Design for Project L-310, "Distribution Water Line" which replaces a 2.5-mile section of the 24" export water line in the 200 West Area by May 26, 2000. 


\section{Cost Performance (\$M):}

\begin{tabular}{|l|c|c|c|}
\hline & BCWP & ACWP & VARIANCE \\
\hline Landlord & $\$ 5.1$ & $\$ 3.0$ & $\$ 2.1$ \\
\hline
\end{tabular}

The $\$ 2.1$ ( $42 \%$ percent) favorable cost variance is mainly attributed to the auction of six cranes for which a credit was received. Further information at the PBS level can be found in the following Cost Variance Analysis details.

\section{Schedule Performance $(\$ M)$ :}

\begin{tabular}{|l|c|c|c|}
\hline & BCWP & BCWS & VARIANCE \\
\hline Landlord & $\$ 5.1$ & $\$ 6.3$ & $-\$ 1.2$ \\
\hline
\end{tabular}

The $\$ 1.2$ (19 percent) unfavorable schedule variance is mainly attributed to two ambulances that are behind the scheduled delivery date and funding reductions that impacted work scope related to Project L-314, Law Enforcement and Security Training Center. Renovations for water and restroom facilities will be deferred. Further information at the PBS level can be found in the following Schedule Variance Analysis details.

\section{FY 2000 Cost/Schedule Performance - All Fund Types Cumulative to Date Status - $(\$ 000)$}

FYTD

By PBS

\begin{tabular}{lllllll}
\hline BCWS & BCWP & ACWP & SV & $\%$ & CV & $\%$
\end{tabular}

PEM

PBS TP13

WBS 1.5
Landlord
S $6,280 \$ 5,078$
$\$ 2,998$
S $(1,202)-19 \%$ \& 2,080
$41 \% \$ \quad 14,328$
Total
\$ 6,280
\$ 5,078
\$ 2,998
S $(1,202)-19 \%$ \& 2,080
$41 \% \$ 14,328$ 


\section{COST/SChedule Performance Indices \\ (MARCH 2000 AND FYTD)}

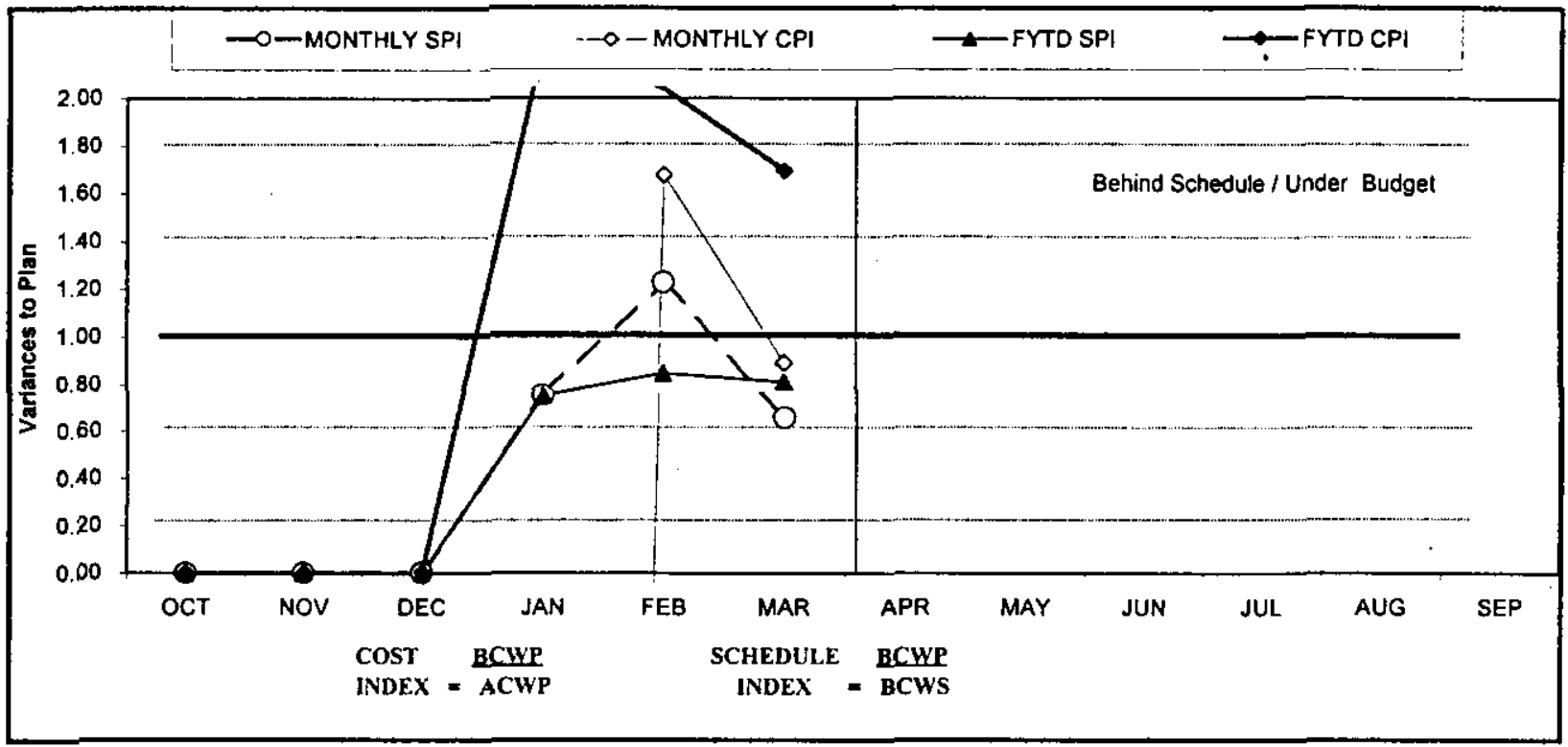

\begin{tabular}{|c|c|c|c|c|c|c|c|c|c|c|c|c|}
\hline FY 2000 & $\overline{\mathrm{OCY}}$ & Nov & DEC & JAN & FEB & MAR & APR & MAY & JUN & JUL & AUG & SEP \\
\hline MONTHL Y SPI & 0.00 & 0.00 & 0.00 & 0.75 & 1.22 & 0.66 & & & & & & \\
\hline MONTHL Y CPI & 0.00 & 0.00 & 0.00 & -19.59 & 1.68 & 0.89 & & & & & & \\
\hline FYTD SPI & 0.00 & 0.00 & 0.00 & 0.75 & 0.84 & 0.81 & & & & & & \\
\hline FYTD CPI & 0.00 & 0.00 & 0.00 & 2.24 & 2.04 & 1.69 & & & & & & \\
\hline MONTHLY BCWS & so & 50 & so & 54,048 & 51,016 & 51,215 & $\$ 1,115$ & 51,385 & $\$ 1,145$ & 51,186 & 51,430 & $\$ 1,786$ \\
\hline MONTHLY BCWP & so & 50 & so & 53.036 & $\$ 1,243$ & 5800 & & & & & & \\
\hline MONTHI Y ACWP & (\$197) & $\$ 943$ & 5767 & $(5155)$ & 5741 & 5899 & & & & & & \\
\hline FYTD BCWS & so & 50 & 50 & $\$ 4,048$ & $\$ 5,065$ & 56,280 & 57,395 & $\$ 8,780$ & $\$ 9,926$ & 511,111 & $\$ 12,541$ & $\$ 14,328$ \\
\hline FYTD BCWP & 50 & 50 & So & $\$ 3,036$ & $\$ 4,279$ & $\$ 5,078$ & & & & & & \\
\hline FYTD ACWP & (\$197) & 5746 & 51,513 & 51,358 & $\$ 2,099$ & $\$ 2,998$ & & & & & & \\
\hline
\end{tabular}

\section{COST VARIANCE ANALYsIS: $\quad(+\$ 2.1 \mathrm{M})$}

\section{WBS/PBS}

\subsection{1/TP-13} trade in of six cranes for which a credit was received. Procurement of one new crane will be received next year (long lead procurement). In addition, the Municipal Planning Process and the Infrastructure Plan are underruning because they are behind schedule. Demolition cost for building 609C for Project L-270, Emergency Services Renovation was less than planned. Workscope for this project is being completed on a fixed price contract and construction cost will be higher than planned, making up the difference. Also, line item funding that has been returned (for Headquarters $10 \%$ Reprogramming) is still in the baseline and reflecting a cost variance. Impact: No impact to overall project and/or final cost.

Corrective Action: A requisition has been entered into Passport to procure the new crane, which replaces the six sold at auction. A Baseline Change Request is in process that defers workscope and also reprograms line item funding on completed projects. 


\section{SCHEDUle VARIANCE ANALYsis: (-\$ 1.2M)}

\section{WBS/PBS}

\subsection{1/ TP13}

\section{Title}

Description /Cause: The $\$ 1.2$ million (19\%) unfavorable schedule variance is mainly attributed to two ambulances that are behind the scheduled delivery date. Also, funding reductions have impacted start of Project L-314, Law Enforcement and Security Training Center. Definitive Design for the renovations of water and restroom facilities will be deferred and documented on a Baseline Change Request. The Municipal Planning Process and the Infrastructure Plan are behind schedule due to priorities related to completion of the Comprehensive Land Use Plan. Construction to install a new system to replace the chlorinating system at the 200 West Area Water Treatment Plant was planned as a fixed price contract. A Plant Force Work Review deemed the work to be plant forces, resulting in a schedule variance. Definitive Design has been completed and procurement contracts started for materials.

Impact: Funding reductions require that scope be deferred for Project L-314 through a Baseline Change Request. Ambulances are on order and should be received soon with no impact. Other project delays are projected to be overcome with no overall impact to the project.

Corrective Action: A Baseline Change Request has been processed (LPM-2000-005) that defers workscope related to funding reductions. Definitive Design for Project L-314, Law Enforcement and Security Training Center will begin in FY 2001 and road refurbishment work has also been deferred.

\section{ISSUES}

There are no technical, DOE, Regulator or external issues identified at this time.

\section{Baseline Change Requests Currently in Process (\$000)}

\begin{tabular}{|c|c|c|c|c|c|c|c|c|c|}
\hline $\begin{array}{l}\text { PROJECT } \\
\text { CHANGE } \\
\text { NUMBER }\end{array}$ & $\begin{array}{c}\text { DATE } \\
\text { ORIGIN. }\end{array}$ & BCR TITLE & $\begin{array}{l}\text { FYO0 COST } \\
\text { IMPACT } \$ 000\end{array}$ & $\mathrm{SCH}$ & TECH & $\begin{array}{l}\text { DATE TO } \\
\text { CCB }\end{array}$ & $\begin{array}{c}\text { CCB } \\
\text { APR'VD }\end{array}$ & $\begin{array}{c}\text { RL } \\
\text { APRVD }\end{array}$ & $\begin{array}{l}\text { CURRENT } \\
\text { STATUS }\end{array}$ \\
\hline LPM-00-00! & $11 / 3 / 99$ & $\begin{array}{l}\text { MYWP Baseline Modification } \\
\text { (Bridge BCR FY00, 01, 02) }\end{array}$ & $\$ 4,642$ & $\mathrm{x}$ & $\mathrm{x}$ & $1 / 11 / 00$ & $1 / 14 / 00$ & $1 / 27 / 00$ & Approved by RL. \\
\hline LPM-00-003 & $12 / 8 / 99$ & Document FY99 Carryover Funds & $\$ 1,793$ & & $\mathbf{x}$ & $12 / 13 / 00$ & $1 / 3 / 00$ & $1 / 3 / 00$ & Approved by RL \\
\hline LPM-00-005 & $3 / 23 / 00$ & $\begin{array}{l}\text { Document Rate Increase, Funding } \\
\text { Reductions, and Impacts to } \\
\text { Milestones }\end{array}$ & $\$<318>$ & $\mathrm{x}$ & $\mathrm{x}$ & $4 / 13 / 00$ & & & $\begin{array}{l}\text { Recommended changes } \\
\text { from FH Change Control } \\
\text { Boerd being } \\
\text { incorpornted. }\end{array}$ \\
\hline \multicolumn{10}{|c|}{ ADVANCE WORK AUTHORIZATIONS } \\
\hline - & $3 / 20 / 0$ & $\begin{array}{l}\text { L-298, Rogd Refurbishment } \\
\text { (Rattlesnake Barricade } \\
\text { Modifications) }\end{array}$ & $\$ 110$ & & $\mathrm{x}$ & - & - & $3 / 23 / 00$ & $\begin{array}{l}\text { Scope being added } \\
\text { to baseline per BCR } \\
\text { LPM-00-005. }\end{array}$ \\
\hline
\end{tabular}


PHMC Environmental Management Performance Repon 13 , 2000

Section $\boldsymbol{H}$-Landlord

\section{MILESTONE ACHIEVEMENT}

\begin{tabular}{|c|c|c|c|c|c|c|c|c|}
\hline \multirow[b]{2}{*}{ MILESTONE TYPE } & \multicolumn{2}{|c|}{ FISCAL YEAR-TO-DATE } & \multirow[b]{2}{*}{$\begin{array}{c}\text { Completed } \\
\text { Late }\end{array}$} & \multirow[b]{2}{*}{ Overdue } & \multicolumn{3}{|c|}{ REMAINING SCHEDULED } & \multirow[b]{2}{*}{$\begin{array}{c}\text { TOTAL } \\
\text { FY } 2000\end{array}$} \\
\hline & $\begin{array}{c}\text { Completed } \\
\text { Early }\end{array}$ & $\begin{array}{c}\text { Completed } \\
\text { On Schedule }\end{array}$ & & & $\begin{array}{c}\text { Forecast } \\
\text { Early }\end{array}$ & $\begin{array}{c}\text { Forecast } \\
\text { On } \\
\text { Schedule }\end{array}$ & $\begin{array}{c}\text { Forecast } \\
\text { Late }\end{array}$ & \\
\hline Enforceable Agreement & 0 & 0 & 0 & $\overrightarrow{0}$ & 0 & 0 & 0 & 0 \\
\hline DOE-HQ & 0 & 0 & 0 & 0 & 0 & 0 & 0 & 0 \\
\hline $\mathbf{R L}$ & 0 & 0 & 0 & 1 & 0 & 12 & 0 & 13 \\
\hline Total Project & 0 & 0 & 0 & 1 & 0 & 12 & 0 & 13 \\
\hline
\end{tabular}

Nothing to report.

Tri-Party Agreement / EA Milestones

Nothing to report.

DNFSB Commitments

\section{MILESTONE EXCEPTION REPORT}

Number/WBS Level

Milestone Title

Baseline

Forecast

\section{OVerdue - 1}
LLP-00-445 RL
Complete Definitive Design for Project
$03 / 03 / 00$
N/A
1.5.1
L-314, "Law Enforcement and Security
Training Center Renovations"

Date

Date

Cause: Workscope has been deferred due to funding reductions directed by RL.

Corrective Action: A Baseline Change Request is in process to delete this milestone.

\section{FORECAST LATE - 0}




\section{Performance Objectives}

The items listed below are not Performance Incentives. They are performance goals (i.e., milestones and goals between FH and the subcontractor).

\begin{tabular}{|c|c|c|}
\hline Outcome & Performance Goals & Status \\
\hline \multirow{6}{*}{$\begin{array}{c}\text { Restore the River } \\
\text { Corridor for } \\
\text { Multiple Uses } \\
\& \\
\text { Transition the } \\
\text { Central Plateau }\end{array}$} & $\begin{array}{l}\text { Replace 1,500 Feet of 2-inch Sanitary } \\
\text { Water Line from 272AW Building } \\
\text { Along Canton Ave. in the } 200 \text { East } \\
\text { Area }\end{array}$ & $\begin{array}{l}\text { Definitive Design is approximately } 90 \% \text { complete and on } \\
\text { schedule to complete by April } 28,2000 \text {. The current status } \\
\text { supports construction completion on schedule by September } \\
29,2000 \text {. }\end{array}$ \\
\hline & $\begin{array}{l}\text { Provide Vegetation and Animal } \\
\text { Control to Reduce/Minimize the } \\
\text { Spread of Contamination }\end{array}$ & $\begin{array}{l}\text { Treated } 3,000 \text { acres fiscal year to date. Activities continue } \\
\text { as scheduled. }\end{array}$ \\
\hline & $\begin{array}{l}\text { Disposition } 38 \text { Abandoned Legacy } \\
\text { Non-Radioactive Waste Sites }\end{array}$ & Project remains on schedule. \\
\hline & $\begin{array}{l}\text { Complete Installation of } 100 \mathrm{~K} / \mathrm{D} \\
\text { Emergency Notification Sirens which } \\
\text { will Complete the Total Integration of } \\
\text { All Outside Sirens }\end{array}$ & $\begin{array}{l}\text { Definitive Design for the retrofit of emergency sirens at } \\
100 \mathrm{~K} / \mathrm{D} \text { was completed on February } 17,2000 \text { as scheduled } \\
\text { and supports completion of the siren modification at } 100 \mathrm{~K} / \mathrm{D} \\
\text { by July } 28,2000 \text {. }\end{array}$ \\
\hline & $\begin{array}{l}\text { Complete Emergency Services } \\
\text { Renovation of the } 200 \text { Area Fire } \\
\text { Station }\end{array}$ & $\begin{array}{l}\text { Demolition of } 609 \mathrm{C} \text { was completed on February } 23,2000 \text {, } \\
\text { two months ahead of schedule. Construction completion of } \\
\text { the new Administration/Dormitory wing is approximately } \\
\text { one month ahead of the scheduled completion date of April } \\
6,2001 \text {. }\end{array}$ \\
\hline & $\begin{array}{l}\text { Shutdown Approx. } 20 \text { Vacant Office } \\
\text { Facilities - Deactivate } 25 \text { Vacant } \\
\text { Facilities }\end{array}$ & $\begin{array}{l}10 \text { facilities have been shutdown for the fiscal year and } 16 \\
\text { facilities have been deactivated. Project remains on } \\
\text { schedule. }\end{array}$ \\
\hline $\begin{array}{l}\text { Put Assets to } \\
\text { Work for the } \\
\text { Future }\end{array}$ & $\begin{array}{l}\text { Disposition One Well Car and One } \\
\text { Flat Car - Surveillance and } \\
\text { Maintenance of Legacy Rail Cars at } \\
\text { 212R Awaiting Disposition }\end{array}$ & $\begin{array}{l}\text { Radiological survey and samples of the flat car is complete. } \\
\text { Preliminary investigation into an option to prepare the } \\
\text { Burlington Northem Santa Fe flat cars for free release at } \\
\text { Hanford was initiated. The National Environmental Policy } \\
\text { Act Categorical Exclusion review package was received by } \\
\text { DOE-RL and has started internal reviews. }\end{array}$ \\
\hline
\end{tabular}

\section{KEY INTEGRATION ACTIVITIES}

Continue to support $\mathrm{RL}$ on the following activities to implement the Comprehensive Land Use Plan (CLUP) for the Hanford Site:

- $\quad$ Finalizing the CLUP implementation vision, goals, and objectives.

- Developing a presentation on the CLUP Land and Facility Use Process (municipal approach).

- $\quad$ Establishing a Hanford Site Planning Advisory Board made up of cooperating agencies and Tribal representatives. 
- Developing Area and Resource Management Plans (c.g., Landlord Infrastructure Master Plan).

- $\quad$ Finalizing the CLUP Hanford Site Implementing Directive to institutionalize the CLUP sitewide.

\section{Building Deactivation}

Building Deactivation as of March 31,2000

60

50

40

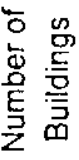

DFYOO MYWP

EM Mgnt Commitm't

- FY00 Current Baseline

GFYTD Planned

DFYTD Actual

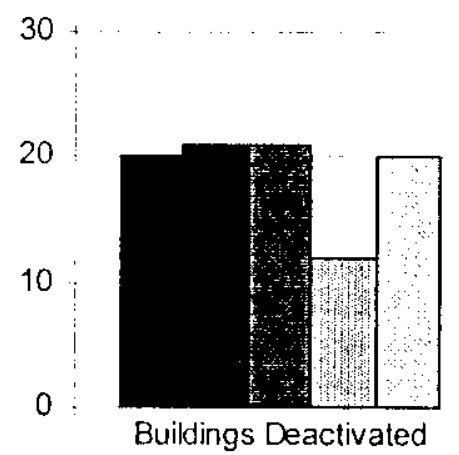

Buildings Deactivated

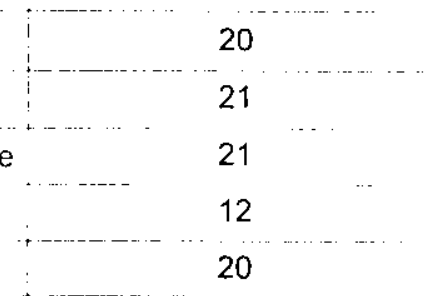

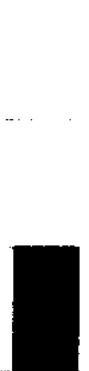

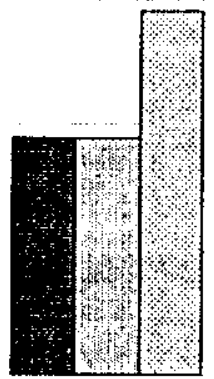

Bldg. Not Yet Deactivated

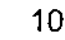

0

19

19

29

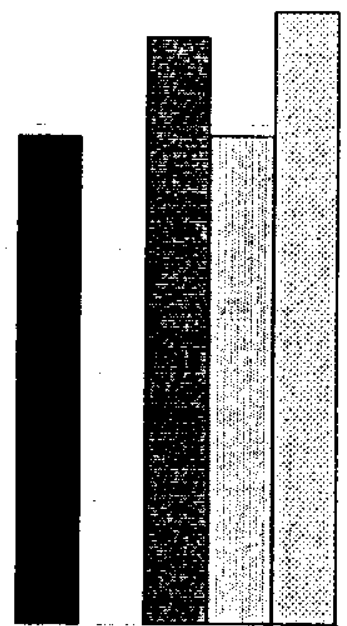

Post Deactivation

39

0

47

39

49

Buildings Deactivated: More buildings were vacated this period than planned and some of these additional buildings were deactivated because the action was simple and relatively inexpensive. See buildings not yet deactivated for more information.

Buildings Not Yet Deactivated: These totals represent buildings in queue for deactivation. The baseline and planned totals represent the number expected remaining at the end of the year. This is dependent on actions of other projects and is not within Landlord control. Comparisons from period to period are not meaningful. Buildings flow from this category and impact the totals in buildings deactivated and those in post deactivation.

Post Deactivation Monitoring: More buildings were vacated this period than planned. These buildings were deactivated and are now in post deactivation. 


\section{FACILITY DeCOMmISSIONING - CleANUPS}

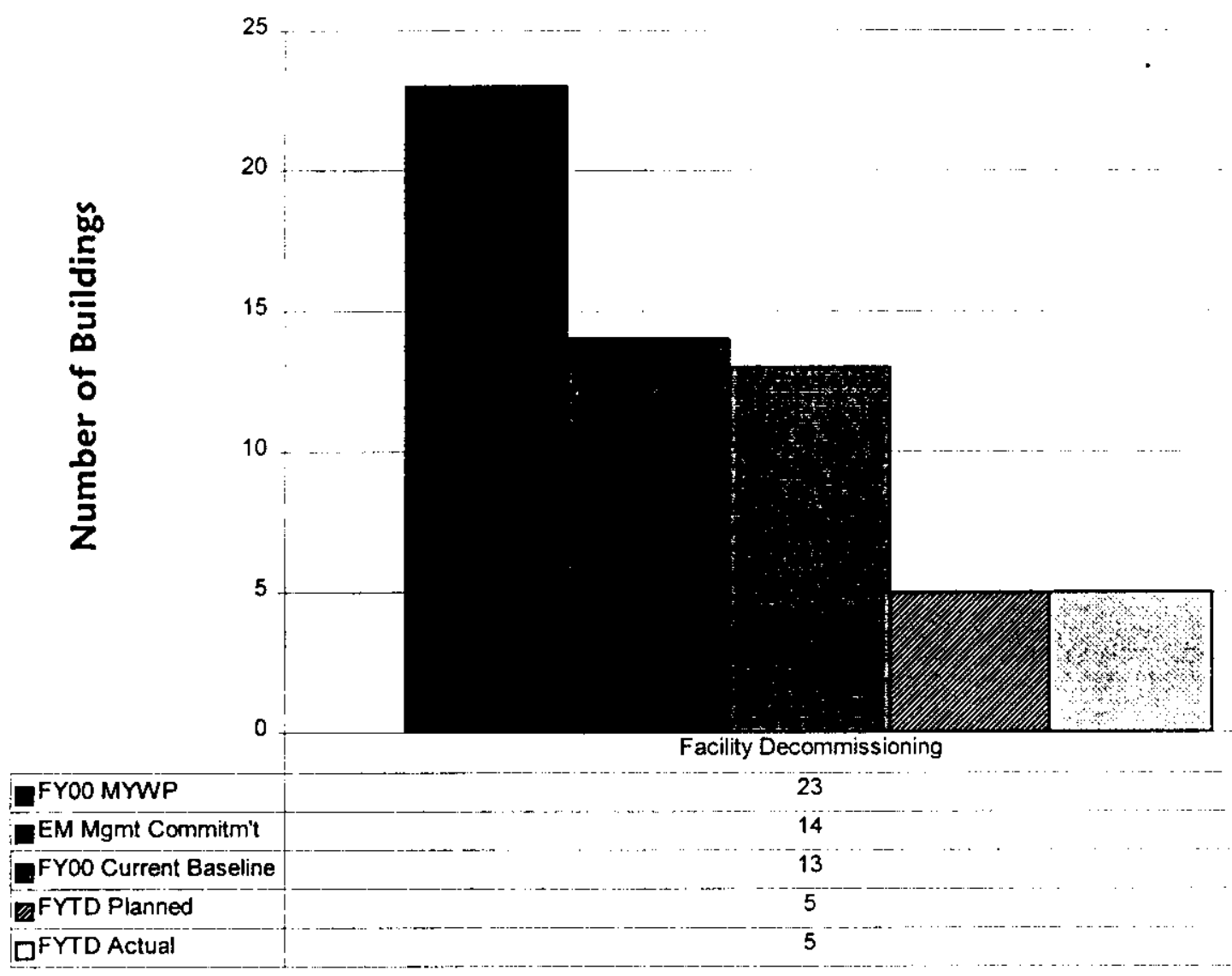

Facility Decommissioning: Five facilities were decommissioned FYTD as planned. 

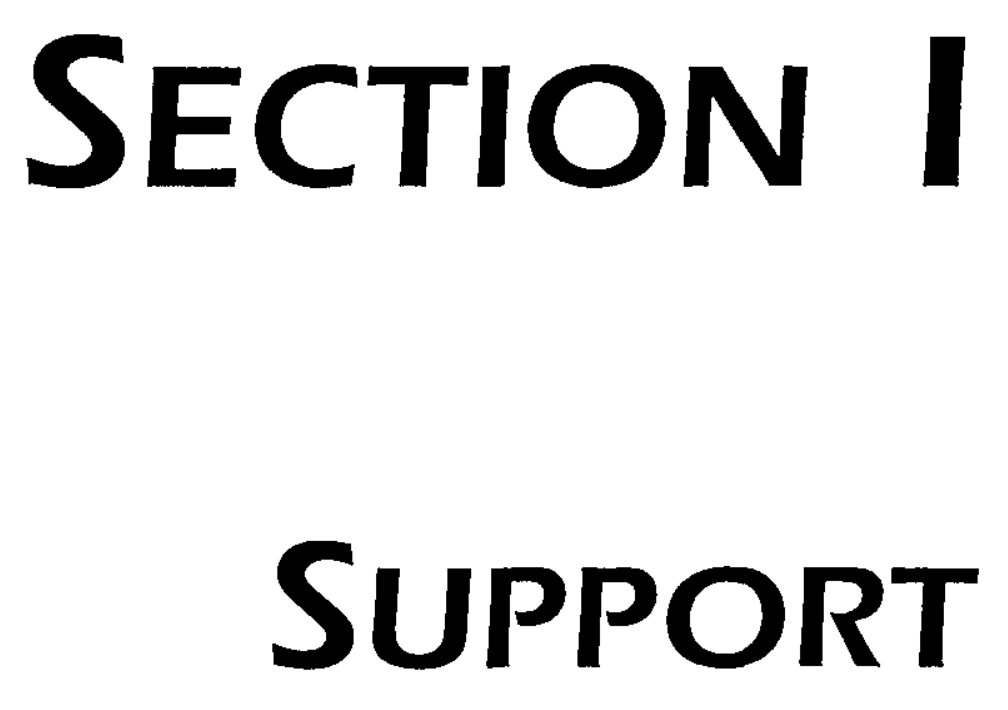

PROJECT MANAGERS

SP\&I W. W. Ballard, RL G. J. McCleary, FH

SSE W. W. Ballard, RL M. L. Grygiel, FH

ECP S. H. Wisness, RL

$$
\text { J. W. Hales, FH }
$$

PSRP S. H. Wisness, RL

R. L. Dirkes, PNNL
(509) 376-6657

(509) 372-8385

(509) 376-6657

(509) 372-2983

(509) 373-9337

(509) 376-4069

(509) 373-9337

(509) 376-8177 


\section{SUMMARY}

Mission Support, Project Baseline Summary (PBS) OT01, consists of four sub-projects:

- $\quad$ Planning and Integration [Work Breakdown Structure (WBS 1.8.2.1)]

- $\quad$ Systems Engineering (WBS 1.8.2.2)

- $\quad$ Environmental Compliance (WBS 1.8.2.3)

The Environmental Compliance Program is composed of two elements. These two elements were stand-alone programs known as the Hanford Environmental Management Program (HEMP) and the Effluent and Environmental Monitoring Program (EEM) prior to FY99. Although there is a single program, these elements retain their identity on the Integrated Priority List as two separate Units of Analysis.

- $\quad$ Public Safety and Resource Protection (WBS 1.8.2.4)

In addition, Richland Directed Activities, PBS OT04, is included in this section. It consists of general site requirements such as:

- $\quad$ Resource Conservation and Recovery Act [RCRA] Mixed Waste Fee (management fee)

- Department of Health (DOH) Oversight (air monitoring)

- Downwinder Litigation

- Permits/site support [State of Washington (air emissions program)]

- $\quad$ Emergency Preparedness Grants

- State of Oregon Hanford Oversight

- $\quad$ Payment in Lieu of Taxes

- Hanford Advisory Board/Miscellaneous Grants (Hanford Openness Panel)

- Uranium Mass Balance Project (Paducah)

- National Security Analysis (formerly declassification of documents)

- Other minor financial assistances and contracts.

NOTE: Unless otherwise noted, the Safety, Conduct of Operations, Milestone Achievement, and Cost/Schedule data contained herein is as of March 31,2000. All other information is as of April $26,2000$.

Fiscal-year-to-date milestone performance (EA, DOE-HQ, and RL) shows that 18 of 20 milestones ( 90 percent) were completed on or ahead of schedule, 1 milestone ( 5 percent) was completed late and 1 milestone (5 percent) is overdue. The Milestone Achievement details, found following cost and schedule variance analysis, provide further information on all milestone types.

\section{Site Planning and Integration (SP\&I)}

Project Baseline Summary (PBS) Activities - Budget Module training in the HQ Integrated Planning Accountability and Budget System (IPABS) was provided for the projects during a kickoff meeting in early March. This is a new module to collect the Budget Formulation 
data for the FY 2002 Budget. The Projects submitted text in the Fluor IPL module for prioritization. This text was batch fed into the IPABS for the PBS Budget Formulation data. The draft submission of this data was sent on April 7,2000.

Integrated Priority List (IPL) Activities - Work continued on the IPL to ensure that the database was consistent with the IPL submitted to RL on February 25, 2000. The remainder of the contractors' data was loaded into the IPL module for integration. SP\&I prepared for the presentation of the draft FY 2002 IPL to the Site Management Board (SMB). Subsequent decisions were integrated into the IPL. The data included in the IPL module was used to produce the "Blue Book" for the FY 2002 Public Meetings held from March 15-24, 2000. The "Blue Book" provided a summary of the benefits for each Unit of Analysis on the IPL as well as the regulatory drivers that require the work to be done. The IPL was batch fed to the HQ IPABS on April 14,2000 after being converted to the EM peer review work classification categories.

\section{Geographic Site Level (GSL) and Hanford Site Summary Level (SSL)}

Submissions — Data was collected from all site contractors for completion of the DOE-HQ GSL and SSL requests. These summaries portray the life cycle costs by Category/Subcategory, discuss the top 10 risks at the site and the mechanisms for continuous feedback and improvements for safety and health.

UNICALL - Numerous crosscuts were requested by the FY 2002 DOE HQ CFO's UNICALL which are not collected by the HQ Environmental Management Program. To date, crosswalks submitted include: Nuclear Safeguard and Security Draft exhibit and the Draft Energy - Arms Control - Non Proliferation exhibit.

FY 2002 Fluor 10 percent Base Operations Reduction — In early March, impact statements were collected from the Projects on the directed 10 percent Base Operations reduction. The impacts were categorized as: no impact, reduced work level or scope while still completing the mission, reductions requiring changes to procedures or $\mathrm{RL}$ support/approval, deferred work scope, and deleted work scope. Nearly 5 percent of the identified work scope would require deferrals or deletions. Work continues and the results will be incorporated into the upcoming MYWP updates.

Summary Schedule Modeling Tool - Work continued on developing a summary schedule product for use in assessing various EM work-scope schedule alternatives. The source for this product is detailed project schedules. Meetings were held with project personnel, including BHI, to obtain necessary crosscutting data elements to support product criteria. The PHMC portion of the product is on schedule to be provided in early May. It is anticipated that this product will replace summary schedules currently prepared/updated by project organizations on a monthly basis.

Central Milestone Module (CMM) Modifications - New milestone reports were developed in CMM to support IPABS reporting requirements. Modifications are also underway to allow controlled update of baseline milestone information by project personnel, as opposed to 
a central system administrator. It is anticipated that there will be an improved timeliness of baseline updates as a result of these changes.

FYSF/EAC Review - The review and analysis of Fiscal Year Spend Forecast (FYSF) data from the projects continues. After a series of meetings with the Chief Operating Officer (COO), actions to address projected problems in some areas as well as providing funding sources for a number of stretch and super stretch initiatives were recommended. SP\&I is now working closely with the projects to implement those actions selected by the $\mathrm{COO}$.

Performance Management Meetings - The first quarterly PHMC Services / Support / Comprehensive Performance Incentives (PI)s meeting was held on March 16, 2000. Addressed were the Site Services organizations (including Landlord, Safeguards and Security, and Emergency Preparedness), the Analytical Services Labs, and performance relating to FH's Comprehensive Performance Incentive. The next quarterly meeting (scheduled for June 6, 2000) will also include Information Resource Management activities.

Environmental Management Performance Report (EMPR) - The April EMPR was delivered on April 7, 2000 as planned. The May EMPR schedule has been accelerated one and one-half weeks as requested to support the mid-year review with DOE-HQ. Currently, delivery of bound copies is planned for May 5, 2000.

Business Management Oversight Process (BMOP) Status - FH BMOP point of contacts are in the process of determining the existing documents and reports which demonstrate the fulfillment of BMOP criteria. Some FH functional managers are working to modify or delete BMOP sections. If necessary, SP\&I will prepare a response to the BMOP plan identifying any expectations that $\mathrm{FH}$ is unable to adhere to within existing baselines.

\section{SYSTEMS ENGINEERING AND INTEGRATION (SEI)}

Technical Baseline Products - Systems Engineering and Integration continued to support the projects in the PBS submittal.

SEI continues to support the Schedule Options Study.

Management Systems Solutions - FH Systems Engineering and Integration is working with CH2M Hill (CHI) Systems Engineering to determine future support to the Hanford Site Technical Database (HSTD) as the source of data for various HQ data calls. Based on recent organizational actions taken at CHI, there is a concern that future support to the HSTD may be discontinued.

SEI is performing a review of the management system descriptions to determine if they reflect SEI requirements.

The reconfiguration of the Configuration Management Plan and its implementing documentation is continuing. It will be released for review upon approval of HNF-PRO-589. 
SEl Infrastructure - FH has decided to integrate the Hanford Site Technical Database (HSTD), Standards Requirements Identification Documents (S/RIDs) and Project Hanford Management System (PHMS) into a single requirements management system. A contract has been put in place with Structural Dynamics Research Corporation (SDRC) to procure the SLATE software, which will serve as the platform, for the single system.

Systems Engineering and Integration is in the process of building a hyperlink capability for the HSTD products. This will allow for easy navigation between documents to facilitate reviews and traceability verification.

Project Support — FH SEI and FH Waste Management (WM) are working with BHI to resolve a conflict between $\mathrm{BHI}$ 's planned cleanup dates and PHMC's planned turnover of waste sites to $\mathrm{BHI}$.

SEI is coordinating project inputs to stream disposition data to HQ for use in developing an integrated disposition plan for wastes and materials across the DOE complex.

SEI is facilitating efforts with the ER contractor to plan life cycle disposition of all buildings and waste sites at Hanford.

\section{Environmental Compliance Program (ECP)}

\section{RCRA Permit Revision and Implementation}

- Continued coordination and preparation for an Appeal of the Modification E proposed Permit modifications.

- Held strategy meeting for Corrective Action portion on the Resource Conservation and Recovery Act (RCRA) Permit issued on March 28, 2000. Reviewed and provided interpretation of the Permit revision, if the Permit has authority over the TPA, and when and if Ecology might use the Permit to enforce TPA milestones.

- Coordinated Sitewide input for the Class 1 modifications for quarter ending March 31, 2000. Completed a 14-day review of the modifications on March 10,2000, and incorporated comments. Transmitted the Class 1 modification package on March 29, 2000, which included modifications to Attachment 4, PUREX Storage Tunnels, Liquid Effluent Retention Facility (LERF)/Effluent Treatment Facility (ETF), 242-A Evaporator, 305-B Storage Facility, and 325 HWTUs. The modification was transmitted on March 29.

- $\quad$ Reviewed and commented on T Plant permitting strategy.

- $\quad$ Reviewed and commented on DYNCORP waste management plan for the emergency decontamination facility.

- Developed cost and impacts for Hanford RCRA Permit Modification E draft permit conditions.

- $\quad$ Supported FH Emergency Preparedness on permit modifications for the Hanford Emergency Management Plan DOE/RL-94-02.

- $\quad$ Provided Hanford Site RCRA compliance history to PNNL for the 1999 Site Environmental Report. 
Air

- Functioned as the Point-of-Contact for FH with the Washington State Department of Health (WSDOH) Olympia and Richland offices, regarding the Washington State Radioactive Air Emissions Program. Continued to assist with communications between WSDOH, DOE-RL, and facilities including PFP, B Plant, and 222-S laboratory regarding compliance questions, strategies, and permitting associated with radioactive air emission compliance.

- $\quad$ Assisted with the development of compliance strategy for replacement of the 222-S Laboratory main stack, \#296-S-21. Delay of project funding resulted in a delay in final decision regarding whether to permit or claim an exemption from radioactive air emissions permitting for the replacement activities.

- Provided, as requested, a summary of applicable regulatory requirements pertaining to the latest positions taken in recent letters from the WSDOH and Environmental Protection Agency (EPA) regarding location of the Maximally Exposed Individual (MEI) for purposes of modeling offsite radiological dose due to airborne emissions.

- $\quad$ Assisted PFP with regulatory analysis, and arrangement of immediate telecon with WSDOH, to document allowance of continued preliminary work on the cementation preparatory activities, including relocation of an interior door, and installation of a brace structure. These actions were allowed for completion by WSDOH, but with a requirement that no further actions be taken towards construction until the applicable Notice of Construction (NOC) was approved.

- $\quad$ Provided management and integration support to RL in billing verification and tracking asbestos Notice of Intent (NOI) approvals for the PHMC contractors as well as BHI, Johnson Controls Incorporated, and PNNL.

\section{Inspections/Assessments}

- $\quad$ Performed facility assessments:

- PFP [RCRA, Emergency Planning and Community Right-to-Know Act (EPCRA), Toxic Substance Control Act (TSCA), Clean Water Act (CWA), Clean Air Act (CAA), National Environmental Policy Act (NEPA)],

- WRAP - Chemical Management System (CMS),

- $200 \mathrm{LWC}-\mathrm{CMS}$,

- T-Plant - EPCRA,

- $222 \mathrm{~S}-\mathrm{CMS}$,

- WSCF - CMS,

- $\quad$ Solid Waste Treatment - CMS,

- $\quad$ Solid Waste Disposal - CMS,

- $\quad$ Supported State Regulatory Inspections at:

- 200 Area Effluent Treatment Facility (ETF) — Washington State Department of Ecology (WSDE),

- K-Basins - Washington State Department of Health (WSDOH),

- TRUSAF - WSDOH,

- T-Plant - WSDOH,

- WRAP - WSDOH. 
- Defined and initiated the 600 Area Inspection Program.

- Performed the 200 West Area RCRA Permit Inspection.

\section{Compliance}

- Initiated work to proceed as Lead Action Coordinator (LAC) for the Center of Expertise (COE), addressing the compliance orders associated with the 244-AR Vault Notice of Violation issued to ORP on March 15th. The LAC is to determine how the compliance orders might potentially impact $\mathrm{FH}$ facilities.

- $\quad$ Provided compliance update to 1999 Site Environmental Report.

- Coordinated and Facilitated FH Project meetings to review impacts of missed hold times on Waste Sampling and Characterization Facility (WSCF) samples and drafted an action plan to resolve the issue.

- $\quad$ Responded to DOE request for Notice of Deficiency (NOD) response data compilation March 22, 2000.

- Continued recovery actions for the WSCF Test Method deviation issue and associated sitewide impacts, including:

- Issued 2 status updates for the RCRA Focus Action Plan

- $\quad$ Submitted General Information Update \#2 to the EPA and Ecology

- $\quad$ Reviewed/commented on BNFL wastewater compliance permitting strategy for RL-OSS.

- Maintained operation of Exercise Action Tracking System (EATS)/issued 4 weekly EATS compliance status reports

- $\quad$ Provided compliance action presentation to Department of Health (DOH) at Routine Technical Assistance Meeting (RTAM).

- Met with DOH representative and secured closure for seven open enforcement/compliance actions.

- $\quad$ Facilitated discussions on purgewater management within FH and with BHI.

- Developed draft letter for Analytical Services in response to M-32 alleged violations.

\section{Spill and Release Reporting}

- Coordinated the reporting activities for six (6) non-reportable releases of a hazardous substance and /or a petroleum product released to the environment. All of these releases were cleaned up and disposed of per state and federal requirements. There were three (3) reportable events, with a release to the environment and six (6) reportable code noncompliance events that were reported directly to the off site regulatory agency(s) by the FH Environmental Single Point of Contact (SPOC). The HNF-PRO-453, Spill and Release Reporting Procedure is being integrated with HNF-PRO-060, Occurrence Reporting Procedure and will be updated for clarity and more specific guidance for roles and responsibilities for spill and release reporting within the PHMC.

\section{Project Support/Coordination}

- $\quad$ Supported ES\&H involvement in FH process for confirming readiness to proceed with certifying that they are prepared to support the next phase of the ORP/BNFL vitrification 
plant. The evaluation and final results were completed and reviewed. The evaluation result was presented to FH President's Office.

\section{Chemical Management}

- The Chemical Management Value Engineering study completed during the week of March 6 - 10 was considered a success. Many process improvements and cost saving measures were developed and shared with senior management. Senior management embraced the proposals.

- A letter was sent confirming that FH will be using the PNNL-developed Chemical Management System (CMS) database as the inventory and main procurement tool for the Chemical Management Program.

\section{Management and Administrative Support}

- The E\&R website continues to expand to provide users with a one-stop-shop for environmental and regulatory information.

- The Environmental Action Tracking System had high level visibility during the recent negotiations with the EPA and Ecology. Senior RL management requested several reports which were generated from tech data within the system.

\section{Public Safety and Resource Protection (PSRP)}

The PSRP Program was conducted in accordance with the scope, milestones, and budget defined in the FY 2000 PSRP Program (PBS \#RL-OT01) Multi-Year Work Plan during March.

\section{ACCOMPLISHMENTS}

- The deliverable, Support for Richland Public meeting, was completed on March 15, 2000.

- The deliverable, RL/PHMC Senior Monthly Project Review - January was completed on March 10, 2000.

- The deliverable, Monthly EMPR was delivered on March 14, 2000.

- The deliverable, Submit Final FY 2002 IPL was completed on February 25, 2000.

- The deliverable, Submit Suggested Changes to Budget Update Guidance (BUG), was completed on March 29, 2000.

- $\quad$ The deliverable, Submit Draft PBS Part "A" Information, was completed on March 16, 2000.

- The deliverable, Submit the Primary Budget - Nuclear Safeguard and Security Draft Exhibit for the UNICALL, was completed on March 17, 2000.

- The deliverable, Submit the Primary Budget - Attachments E, F, G, \& H Exhibits to RL for the UNICALL, was completed on March 10, 2000.

- $\quad$ The deliverable, Submit the Primary Budget - Draft Energy - Arms Control - Non Proliferation Exhibit for the UNICALL, was completed on March 24, 2000.

- $\quad$ The deliverable, IRB Corporate Forum support, was completed on March 6, 2000.

- The deliverable, IRB Corporate Forum presentation, was completed on March 8, 2000. 
- The deliverable, Logistics Support for FY 2002 Public Meetings Requirements - TPA, was completed on March 15, 2000.

- $\quad$ The deliverable, Submit PBS (Part A) for SP\&I was completed on February 25, 2000.

- Approximately 2000 data inconsistencies between IPABS and Hanford waste records found in FY99 have been resolved. A comparison during April identified only two differences; both were a DOE-HQ control number that can be easily resolved.

- A hyperlinked version of the Hanford Strategic Plan, the Hanford Site Environmental Management Specification (HSEMS), and Multi-Year Work Plans was demonstrated to the Schedule Options Group.

- The Site Model was updated and key elements integrated. Model assumptions are continuing.

- A NEPA Activity Report was completed on April 12, 2000.

- Issue Quarterly NESHAP Status Report for EPA was completed on April 4, 2000.

- An Ecosystem Monitoring data summary to be included in the CY 1999 Annual Environmental Report was submitted on March 15. This completes PNNL Key Milestone RLOT012001, "Provide Ecosystem Monitoring Project Summary Information for the Annual Hanford Site Environmental Report" as scheduled in the FY 2000 PDP.

- $\quad$ The Surface Environmental Surveillance Project (SESP) conducted a Public Environmental Surveillance Forum at the Richland Best Western Tower Inn on March 9. DOE, PNNL, and the Washington State Department of Health sponsored the forum. The forum was well attended by students, members of the public (including retired Hanford workers), the press, and current Hanford employees.

- A one-week Cultural Resource survey of the north Vernita land area was completed in March. The survey documented several cultural resources that had not been previously recorded and also documented the extensive damage that has occurred in the area resulting from public access. The survey was also significant because it was conducted in cooperation with students from Central Washington University.

\section{ISMS STATUS}

The Environmental Compliance Program completed the following:

- ISMS interviews, final ISMS report, and input into Waste Management Project corrective action management plan.

- Designed and fabricated a poster for ISMS workshop.

- Presented EMS/LSMS Integration Overview in ISMS Workshop III.

- Led a breakout session at the ISMS Workshop titled "Integrated Chemical Management" with a panel consisting of staff from Fire Department, Industrial Hygiene, Pollution Prevention, PFP Operations, and Emergency Planning and Community Right-to-Know Act (EPCRA) Reporting.

- Completed Environment and Regulation and Environmental Services ISMS Briefing Books.

\section{UPCOMING ACTIVITIES}

- Submit Revision of 91-28 to be completed by May 1, 2000.

- $\quad$ Provide RL with Air/Water Permitting Schedule to be completed by May 1, 2000. 
- Annual Portable/Temporary Radioactive Air Emissions Units (PTRAEU) and HEPA Vacuum (HVU) Report to be completed by May 15, 2000.

- Annual Radionuclide Air Emissions Report to be completed by May 15, 2000.

- Annual polychlorinated biphenyl (PCB) Document Log for June to be completed by May 23, 2000.

- $\quad$ Emergency Planning and Community Right-to-Know Act (EPCRA) Section 313 Toxic Chemical Release Inventory to be completed by May 23, 2000.

\section{Cost Performance (\$M):}

\begin{tabular}{|l|c|c|c|}
\hline & BCWP & ACWP & VARIANCE \\
\hline Mission Support 1.8 & $\$ 20.3$ & $\$ 18.0$ & $\$ 2.3$ \\
\hline
\end{tabular}

The $\$ 2.3$ million (11 percent) favorable cost variance is due to several factors. Further information at the PBS level can be found in the following Cost Variance Analysis details.

\section{SChedule Performance ( $\$ M)$ :}

\begin{tabular}{|l|c|c|c|}
\hline & BCWP & BCWS & VARIANCE \\
\hline Mission Support 1.8 & $\$ 20.3$ & $\$ 23.5$ & $-\$ 3.2$ \\
\hline
\end{tabular}

The \$3.2 million (14 percent) unfavorable schedule variance is due to several factors. Further information at the PBS level can be found in the following Schedule Variance Analysis details.

\section{FY 2000 Cost/Schedule Performance - All Fund Types Cumulative to Date STATUS - $(\$ 000)$}

$$
\text { FYTD }
$$

\begin{tabular}{|c|c|c|c|c|c|c|c|c|c|}
\hline \multicolumn{2}{|c|}{ By PBS } & BCWS & BCWP & ACWP & \multirow{2}{*}{$\begin{array}{c}\text { SV } \\
\text { \$ }(2,183)\end{array}$} & \multirow{2}{*}{$\begin{array}{c}\% \\
-29 \%\end{array}$} & \multirow{2}{*}{$\begin{array}{c}\text { CV } \\
\$(1,920)\end{array}$} & \multirow{2}{*}{$\begin{array}{c}\% \\
-36 \%\end{array}$} & \multirow{2}{*}{$\begin{array}{c}\text { PEM } \\
\$ 22,044\end{array}$} \\
\hline $\begin{array}{l}\text { PBS OT04 } \\
\text { WBS1.8.1 }\end{array}$ & $\begin{array}{l}\text { RL Directed } \\
\text { Support }\end{array}$ & \$ 7,448 & $\$ 5,264$ & $\$ 7,184$ & & & & & \\
\hline $\begin{array}{l}\text { PBS OT01 } \\
\text { WBS } 1.8 .2\end{array}$ & $\begin{array}{l}\text { Mission } \\
\text { Support Other } \\
\text { MYPs }\end{array}$ & $\$ 16,003$ & $\$ 15,001$ & $\$ 10,792$ & $\$(1,002)$ & $-6 \%$ & $\$ 4,210$ & $28 \%$ & $\$ 24,869$ \\
\hline & Total & $\$ 23,451$ & $\$ 20,266$ & \$ 17,976 & $\$(3,185)$ & $-14 \%$ & $\$ 2,290$ & $11 \%$ & $\$ 46,913$ \\
\hline
\end{tabular}




\section{Cost/SChedule Performance Indices \\ (MARCH 2000 AND FYTD)}

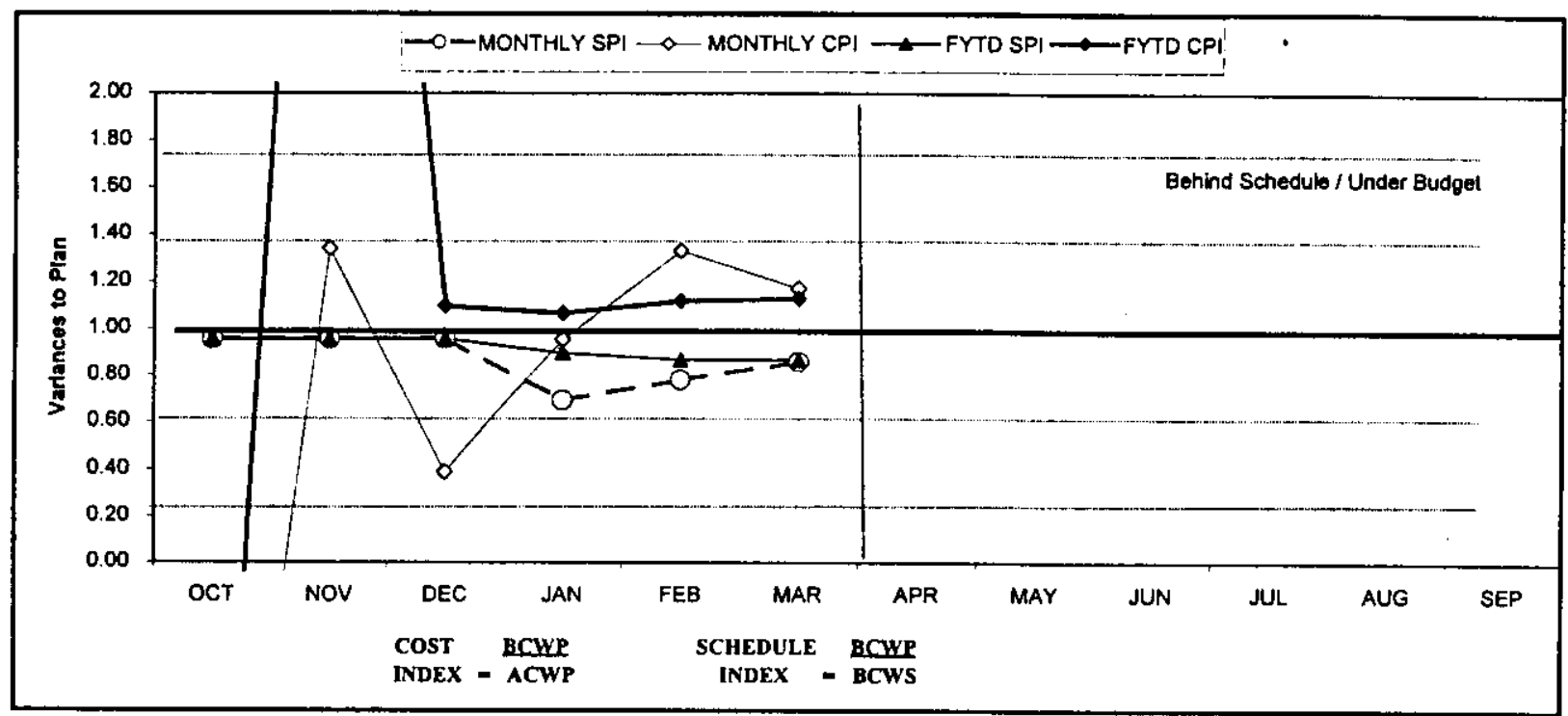

\begin{tabular}{|c|c|c|c|c|c|c|c|c|c|c|c|c|}
\hline FY 2000 & OCT & Nov & DEC & JAN & FE. B & $\overline{\text { MAR }}$ & APR & MAY & JUN & JUL & AUG & SEP \\
\hline MONTHLYSPI & 0.96 & 0.96 & 0.96 & 0.69 & 0.78 & 0.86 & & & & & & \\
\hline MONTHLY CPI & -2.27 & 1.34 & 0.39 & 0.95 & 1.33 & 1.17 & & & & & & \\
\hline FYTD SPI & 0.96 & 0.96 & 0.96 & 0.90 & 0.87 & 0.86 & & & & & & \\
\hline FYTD CPI & -2.27 & 5.83 & 1.09 & 1.07 & 0.12 & 1.13 & & & & & & \\
\hline MONTHLY BCWS & $\$ 3,493$ & 53,716 & 53,221 & $\$ 3,080$ & 54,487 & $S 5,454$ & $\$ 2,495$ & $\$ 2,809$ & 52,354 & 55,021 & $\$ 5,435$ & 55,348 \\
\hline MONTHLY BCWP & $\$ 3.339$ & 53,552 & 53,087 & $\$ 2,126$ & $\$ 3,492$ & 54,669 & & & & & & \\
\hline MONTHLY ACWP & $(\mathbf{S 1 . 4 7 3 )}$ & 52,655 & 57,936 & $\$ 2,232$ & 52,630 & 53,996 & & & & & & \\
\hline FYTD BCWS & 53,493 & 57,209 & $\$ 10,430$ & 513,510 & $\$ 17,997$ & $\$ 23.451$ & 525,946 & $\$ 28,753$ & $\$ 31,109$ & $\$ 36,129$ & $\$ 41,565$ & $\$ 46,913$ \\
\hline FYTD BCWP & 53,339 & $\$ 6,891$ & 59,978 & 512,104 & $\$ 15,596$ & 520,266 & & & & & & \\
\hline FYTD ACWP & $(\$ 1,473)$ & 51,182 & 59,118 & $\$ 11,350$ & $\$ 13,980$ & $\$ 17,976$ & & & & & & \\
\hline
\end{tabular}

\section{COST VARIANCE ANALYSIS: (+2.3M)}

$\underline{\text { WBS/PBS }}$

\subsection{2/OT01}

Description/Cause: The favorable cost variance of $\$ 4.2 \mathrm{M}$ (28 percent) is a combination of off setting factors. Within the Systems Engineering function (1.8.2.2) there is a 24.3 percent unfavorable cost variance that is driven by details in initiating several scheduled activities:

1) The Interface Management Plan,

2) Systems Engineering Assessment,

3) Infrastructure Needs Modeling.

This unfavorable cost variance is offset by a favorable cost variance of 5 percent in Site Planning and Integration (1.8.2.1) and an 11 percent favorable cost variance in the Environmental Compliance Program (ECP) (1.8.2.3). There is also a 12 percent favorable cost variance in the Public Safety and Resource Protection Program (1.8.2.4) driven by less than anticipated activity in some level-of-effort activities and cost not yet accrued associated with the off-site relocation of elk.

Impact: No impact.

Corrective Action: No corrective action required. 


\subsection{1/OT04 RL Directed Support}

Description/Cause: The $\$ 1.9$ million (36 percent) unfavorable cost variance is due to payments in lieu of taxes to Benton, Franklin and Grant Counties are not due to be paid until September / October time frame.

Impact: No impact.

Corrective Action: No corrective action required.

\section{SCHEDULE VARIANCE ANALYSIS: $(-\$ 3.2 \mathrm{M})$}

\subsection{2/OT01 Mission Support}

Description/Cause: The $\$ 1.0$ million (six percent) unfavorable schedule variance is within acceptable reporting thresholds.

Impact: No impact.

Corrective Action: No corrective action required.

\subsection{1/OT04 RL Directed Support}

Description/Cause: The $\$ 2.2$ million (29 percent) unfavorable schedule variance is due to payments in lieu of taxes to Benton, Franklin and Grant Counties are not due to be paid until September / October time frame.

Impact: No impact.

Corrective Action: No corrective action required.

\section{ISSUES}

Issue: Update of project baselines for the impacts of company overhead rate and organizational changes associated with the PHMC restructure (including the ORP split) have not been made pending project submission and approval by $R L$ of baseline change requests.

Impact: Existing Performance Baselines do not reflect potential scope impacts, which impede ability to maintain project performance baselines. Also limits usability of organizational reports.

Corrective Action/Status: Projects indicated that change requests would not be submitted until mid-April potentially impacting the ability to implement the changes in the baseline for April reporting.

\section{DOE/REGULATOR/EXTERNAL ISSUES}

Issue: EPA and Ecology signed the final version of the Resolution of Dispute between Ecology and the DOE regarding Land Disposal Restriction (LDR) issues on March 29, 2000. The DOE has a 30-day window in which to decide whether to challenge the document and prepare a rebuttal.

Impact: A challenge would likely result in a litigation process.

Corrective Actions/Status: Environmental Services personnel continue to support the DOE in evaluating the March 29 Resolution of Dispute and the necessary actions to carry out the requirements as written. 
Issue: In recent letters, EPA and WSDOH requested that the legal definition of the Maximally Exposed Individual (MEI) to radionuclides from the Hanford Site be changed to include certain onsite locations. These locations include non-DOE facilities within the Hanford site boundary, where a member of the public has "unrestricted access".

Impacts: The potential impacts of this new MEI definition will not be fully understood until the modeling effort is complete.

Corrective Action/Status: A statement of work has been prepared to obtain PNNL modeling support.

Issue: SESP staff has not encountered any new significant problems as they continue to work with the contract analytical laboratory to resolve technical problems with the analyses of samples for Tritium and Strontium-90.

Impact: Impacts are minor. They are being managed with periodic contact with the contract laboratory.

Corrective Action/Status: Based on an audit performed in July 1999, the contract analytical laboratory has responded to all of the eight findings/observations. The last outstanding audit item (a self-assessment report) was completed in March:

Documentation on resolution of spiking levels is forthcoming and all work at the laboratory has been completed to closeout this observation. Issuance of the selfassessment will close out the audit. Project staff continue to monitor the contract laboratory closely and they have been very responsive to quick turnaround requests for the elk roundup in March.

\section{Baseline Change Requests Currently in Process}

(\$000)

\begin{tabular}{|c|c|c|c|c|c|c|c|c|c|}
\hline $\begin{array}{l}\text { PROJECT } \\
\text { CHANGE } \\
\text { NUMBER }\end{array}$ & $\begin{array}{c}\text { DATE } \\
\text { ORIGIN. }\end{array}$ & BCR TITLE & $\begin{array}{l}\text { FY00 COST } \\
\text { IMPACT } 5000\end{array}$ & SCH & TECH & $\begin{array}{l}\text { DATE } \\
\text { TO CCB }\end{array}$ & $\begin{array}{c}\text { CCB } \\
\text { APR'VD }\end{array}$ & $\begin{array}{c}\mathbf{R L} \\
\mathbf{A P R} \cdot \mathrm{VD}\end{array}$ & $\begin{array}{c}\text { CURRENT } \\
\text { STATUS }\end{array}$ \\
\hline SPI-2000-002 & $10 / 22 / 99$ & FY T999 Carryover Scope & $\$ 248$ & $X$ & $\mathrm{X}$ & $2 / 3 / 00$ & $2 / 3 / 00$ & & In process \\
\hline SPI-2000-006 & $2 / 37 / 00$ & $\begin{array}{l}\text { Modeling Tool \& IPL Module } \\
\text { Scope Additions FY } 2000\end{array}$ & $\$ 117$ & $\mathrm{x}$ & $\mathrm{X}$ & $2 / 17 / 00$ & $2 / 17 / 00$ & & In Process \\
\hline PSR-2000-001 & & $\begin{array}{l}\text { Alignment of Budget/Scope } \\
\text { to Funding Allocation and } \\
\text { Incorporation of FY } 1999 \\
\text { Carry Over }\end{array}$ & $\$ 193$ & $\mathbf{x}$ & & & & & \\
\hline PSR-2000-003 & & $\begin{array}{l}\text { Adjust project baseline to reflect } \\
\text { repricing changes to Basis of } \\
\text { Estimate, FY } 1999 \text { SAR } \\
\text { Implementation in FY } 2000 \text { and } \\
\text { incorporation of carry over. }\end{array}$ & $\$ 138$ & $\mathrm{x}$ & $\mathrm{x}$ & & & & \\
\hline \multicolumn{10}{|c|}{ ADVANCE WORK AUTHORILATIONS } \\
\hline & & Nothing to report. & & & & & & & \\
\hline
\end{tabular}




\section{Milestone ACHIEVEMENT}

\begin{tabular}{|r|r|r|r|r|r|r|r|r|}
\hline & \multicolumn{3}{|c|}{ FISCAL YEAR-TO-DATE } & \multicolumn{2}{c|}{ REMAINING SCHEDULED } & \\
\cline { 2 - 8 } MILESTONE TYPE & $\begin{array}{c}\text { Completed } \\
\text { Early }\end{array}$ & $\begin{array}{c}\text { Completed } \\
\text { On Schedule }\end{array}$ & $\begin{array}{c}\text { Completed } \\
\text { Late }\end{array}$ & Overdue & $\begin{array}{c}\text { Forecast } \\
\text { Early }\end{array}$ & $\begin{array}{c}\text { Forecast } \\
\text { On } \\
\text { Schedule }\end{array}$ & $\begin{array}{c}\text { Forecast } \\
\text { Late }\end{array}$ & $\begin{array}{c}\text { TY } \\
\mathbf{2 0 0 0}\end{array}$ \\
\hline Enforceable Agreement & 9 & 2 & 0 & 1 & 0 & 14 & 0 & 26 \\
\hline DOE-HQ & 0 & 0 & 0 & 0 & 0 & 2 & 0 & 2 \\
\hline RL & 4 & 3 & 1 & 0 & 0 & 15 & 0 & 23 \\
\hline Total Project & 13 & 5 & 1 & 1 & 0 & 31 & 0 & 51 \\
\hline
\end{tabular}

\begin{tabular}{|c|c|c|c|}
\hline \multicolumn{4}{|c|}{ Tri-Party Agreement / EA Milestones } \\
\hline Number & Milestone Titie & Baseline Date & $\begin{array}{c}\text { Actual } \\
\text { Completion } \\
\text { Date/Status }\end{array}$ \\
\hline ECP-00-302 & $\begin{array}{l}\text { RCRA Permit Class } 1 \text { Mod Notification Quarter } 1 \text { (For } \\
\text { Year 2000-2046) }\end{array}$ & $10 / 01 / 1999$ & $09 / 30 / 1999$ \\
\hline ECP-00-702 & RCRA RPTS/DOCS Closure/Post Closure Cost Est. to RL & $10 / 22 / 1999$ & $10 / 06 / 1999$ \\
\hline ECP-00-901 & Issue Quarterly NESHAP Status RPT to RL for EPA & $10 / 22 / 1999$ & $10 / 20 / 1999$ \\
\hline EPC-00-306 & $\begin{array}{l}\text { Annual Asbestos Notification of Intent (For Year 2000- } \\
\text { 2046) }\end{array}$ & $12 / 31 / 1999$ & $12 / 14 / 1998$ \\
\hline ECP-00-303 & $\begin{array}{l}\text { RCRA Permit Class } 1 \text { Mod Notification Quarter } 2 \text { (For FY } \\
\text { 2000-2046) }\end{array}$ & $01 / 01 / 2000$ & $12 / 16 / 1999$ \\
\hline ECP-00-902 & Issue Quarterly NESHAP Status RPT to RL for EPA & $01 / 28 / 2000$ & $01 / 17 / 1999$ \\
\hline ECP-00-410 & Annual PTRAEU Report to DOE-RL (For FY 2000-2046) & $02 / 01 / 2000$ & Overdue \\
\hline ECP-00-701 & Annual Noncompliance Report to RL & $02 / 17 / 2000$ & $02 / 09 / 2000$ \\
\hline ECP-00-503 & $\begin{array}{l}1999 \text { Hanford Site Annual Dangerous Waste Report (FY } \\
\text { 2000-2046) }\end{array}$ & $02 / 22 / 2000$ & $02 / 22 / 2000$ \\
\hline ECP-00-501 & Tier II Emergency \& Hazardous Chemical Inventory & $02 / 23 / 2000$ & $02 / 23 / 2000$ \\
\hline ECP-00-003 & $\begin{array}{l}\text { Biennial Assess. Of Info. \& Data Access Needs EPA/ECO } \\
(2000-2046)\end{array}$ & $03 / 31 / 2000$ & $03 / 06 / 2000$ \\
\hline ECP-00-801 & Transmit EIS/ODIS Data to INEEL (FY 2000-2046) & $04 / 01 / 2000$ & \\
\hline ECP-00-802 & $\begin{array}{l}\text { Issue Annual Non-Radioactive Airborne Emissions Report } \\
\text { (FY 2000-2046) }\end{array}$ & $04 / 01 / 2000$ & \\
\hline ECP-00-304 & $\begin{array}{l}\text { RCRA Permit Class I Mod Notification Quarter } 3 \text { (For FY } \\
\text { 2000-2046) }\end{array}$ & $04 / 02 / 2000$ & \\
\hline ECP-00-904 & Issue Quarterly NESHAP Status Report To RL for EPA & $04 / 21 / 2000$ & \\
\hline ECP-00-803 & $\begin{array}{l}\text { Issue Annual Radionuclide Air Emissions Report (For FY } \\
\text { 2000-2046) }\end{array}$ & $06 / 15 / 2000$ & \\
\hline ECP-00-502 & EPCRA Section 313 Toxic Chemical Release Inventory & $06 / 23 / 2000$ & \\
\hline ECP-00-504 & Annual PCB Document Log - June & $06 / 23 / 2000$ & \\
\hline ECP-00-305 & $\begin{array}{l}\text { RCRA Permit Class I Mod Notification Quarter } 4 \text { (For FY } \\
\text { 2000-2046) }\end{array}$ & $07 / 02 / 2000$ & \\
\hline ECP-00-505 & PCB Annual Report - July & $07 / 07 / 2000$ & \\
\hline ECP-00-507 & Annual LDR Report (M-26-01) & $07 / 21 / 2000$ & \\
\hline ECP-00-906 & Issue Quarterly NESHAP Status Report to RL for EPA & $07 / 28 / 2000$ & \\
\hline ECP-00-703 & $\begin{array}{l}\text { Coordinate RCRA Pipe Mapping and Marking (For FY } \\
\text { 2000-2046) }\end{array}$ & $09 / 21 / 2000$ & \\
\hline ECP-00-301 & RCRA General Facility Inspections (For FY 2000-2046) & $09 / 30 / 2000$ & \\
\hline \multicolumn{4}{|c|}{ DNFSB Commitments } \\
\hline & Nothing to report. & & \\
\hline
\end{tabular}




\title{
MILESTONE EXCEPTION REPORT
}

\author{
Number/WBS Level \\ Milestone Title \\ Baseline \\ Forecast \\ Date \\ Date

\section{OVERdue - 1} \\ ECP-2000-410 HQ

\subsubsection{4} \\ Annual Portable/Temporary Radioactive \\ Air Emissions Units (PTRAEU) and HEPA \\ Vacuum (HVU) Report to RL \\ $02 / 01 / 00 \quad 06 / 15 / 00$
}

Cause: The 02/01/00 milestone due date does not reflect the due date specified in the Technical Workscope Description for this activity. The $06 / 15 / 00$ due date for this milestone in the Technical Workscope Description is the correct due date.

Impact: No impact.

Corrective Action: Change Request ECP-2000-004 has been submitted to change the date in CMM to $06 / 15 / 00$. Change Requested expected to be approved by $05 / 01 / 00$.

\section{Performance Objectives}

Nothing to report at this time.

\section{KeY INTEGRATION ACTIVITIES}

Systems Engineering and Integration is supporting FH WM's effort to obtain planned turnover dates for all PHMC waste sites per RL request. Comparing this data with information in the Hanford Site Technical Database (HSTD) identified 133 waste sites with planned cleanup completion dates prior to turnover of the waste sites to BHI. SEI and WM are working with BHI to assess impacts of the possibility of an earlier turnover date.

SEI is working with CHI to determine future support needs to the Hanford Site Technical Database (HSTD). There is a potential for the data from RL and Office of River Protection (ORP) to begin to diverge.

SEI supported the Readiness to Proceed evaluation conducted by the ORP. 
PHMC Environmental Management Performance Report-May 2000 Section J-National Programs
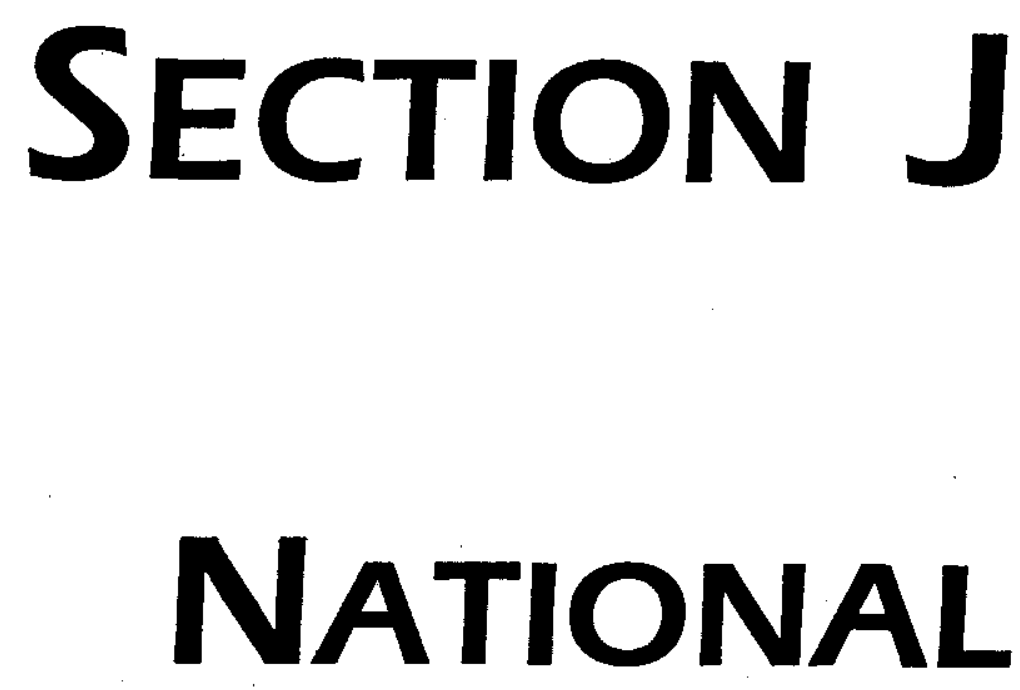
PROGRAMS 


\section{Introduction to National Programs}

DOE EM is responsible for a variety of National Programs. DOE-HQ typically provides operations policy and programmatic guidance to one or more field office that serve as lead for individual programs. FH currently supports the following National Programs: Transportation and Packaging (PBS OT02) and Pollution Prevention and Waste Minimization (PBS WM07).

Transportation and Packaging provides full-service transportation and packaging capabilities. Packaging services for radioactive and hazardous cargo is provided, including regulatory safetybasis documentation, certification, and licensing. Packaging plans and logistical studies for major shipping campaigns are also provided, as well as approved training courses in transportation safety and waste management. Transportation and traffic logistics management, engineering and operational support to offsite customers, carrier selection and evaluation, automated transportation management systems used by the U.S. Department of Energy (DOE) complex and commercial vendors, and international transport of hazardous and radioactive packages are other services provided.

Pollution Prevention and Waste Minimization (P2/WMin) coordinates the development and implementation of a Hanford Site P2/WMin Program to comply with Federal, state, and DOE directives. The program's purpose is to achieve Site objectives through effective and efficient methodologies tailored to generator activities and operations.

\section{FY 2000 Cost/SCHedule Performance - All Fund Types Cumulative to Date Status - (\$000) as of March 31, 2000}

\begin{tabular}{|c|c|c|c|c|c|c|c|c|c|c|c|c|}
\hline & \multirow[b]{2}{*}{ By PBS } & \multicolumn{10}{|c|}{ FYTD } & \multirow[b]{2}{*}{ PEM } \\
\hline & & \multicolumn{2}{|c|}{ BCWS } & \multicolumn{2}{|c|}{ BCWP } & \multicolumn{2}{|c|}{ ACWP } & \multirow{2}{*}{$\begin{array}{c}\text { SV } \\
\text { \$ (157) }\end{array}$} & \multirow{2}{*}{$\begin{array}{c}\% \\
-16 \%\end{array}$} & \multirow{2}{*}{$\begin{array}{c}\text { CV } \\
\$(69)\end{array}$} & \multirow{2}{*}{$\begin{array}{c}\% \\
-9 \%\end{array}$} & \\
\hline $\begin{array}{l}\text { PBS OT02 } \\
\text { WBS } 1.11\end{array}$ & $\begin{array}{l}\text { Transportation \& } \\
\text { Packaging (RL 7601) }\end{array}$ & $\$$ & 962 & $\$$ & 805 & $\$$ & 874 & & & & & $\$ 1,972$ \\
\hline PBS WM07 & $\begin{array}{l}\text { Waste Minimization } \\
\text { (RLHQ 7770) }\end{array}$ & $\$$ & 1,025 & $\$$ & 1,025 & $\$$ & 954 & $\$-$ & $0 \%$ & $\$ 71$ & $7 \%$ & $\$ 3,801$ \\
\hline & Total & $\$$ & 1,987 & $\Phi$ & 1,830 & 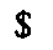 & ,828 & $\$(157)$ & $-8 \%$ & $\$ 2$ & $0 \%$ & $\$ 5,773$ \\
\hline
\end{tabular}

\section{ACCOMPLISHMENTS}

- The updated Safety Analysis Report Packaging (SARP) HNF-SD-017, Rev.2, for (Onsite) Multi-Canister Overpack Cask was completed and issued to RL April 12, 2000.

- Six Transportation and Packaging Project Hanford Management System Procedures have been updated and issued.

- The Washington State Department of Ecology awarded the Hanford Site Recycling Program with the Waste Prevention, Reduction and Recycling Annual Best Federal Facility Award. 


\section{Cost/Schedule Performance INDices (MARCH 2000 AND FYTD)}

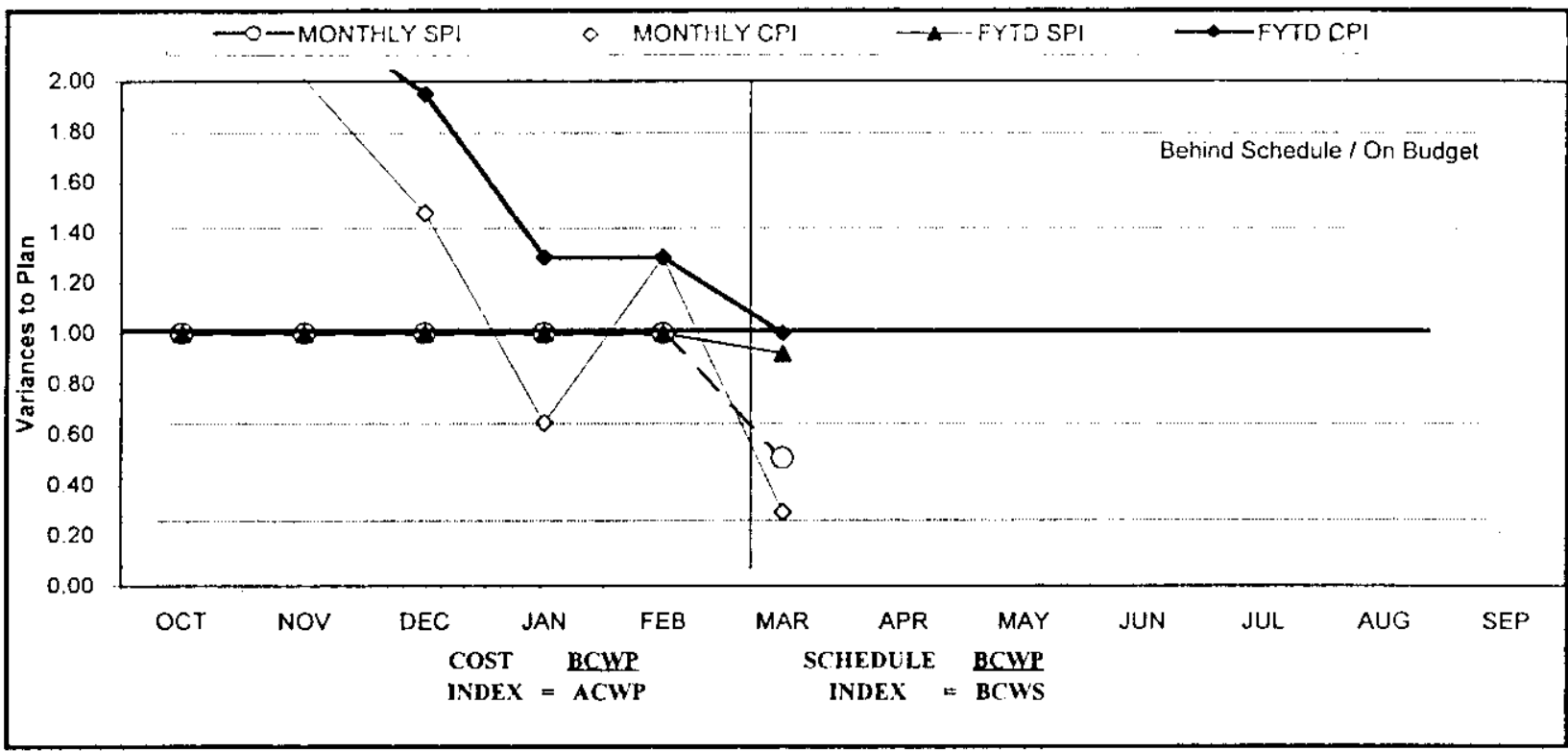

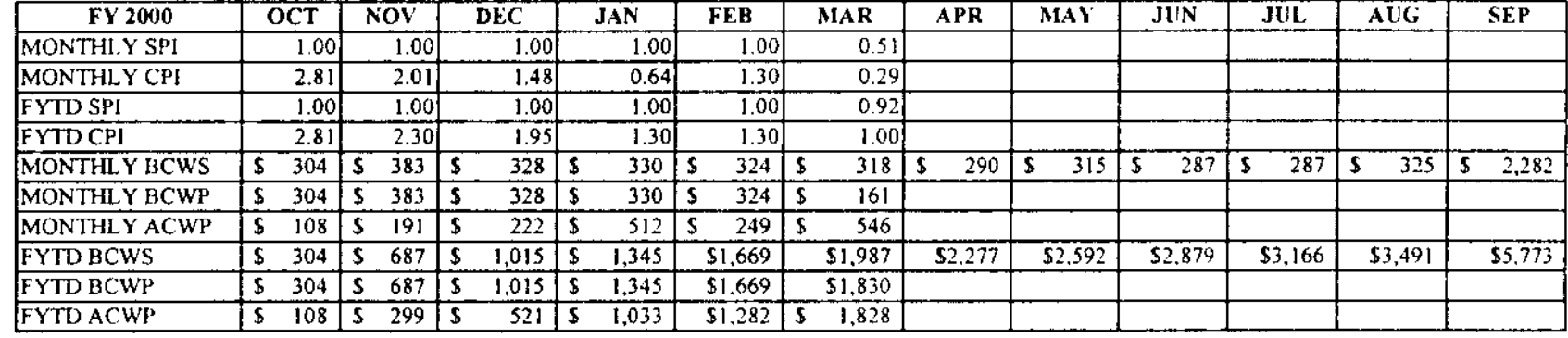

COST VARIANCE ANALYsIS: $(+\$ 0.0 \mathrm{M})$

WBS/PBS

Title

There is no cost variance.

\section{SCHEDULE VARIANCE ANALYSIS: (-\$0.2M)}

WBS/PBS

Title

The schedule variance is within established thresholds. 


\section{Richland Operations Office Environmental Restoration}

\section{Environmental Management Performance Report}

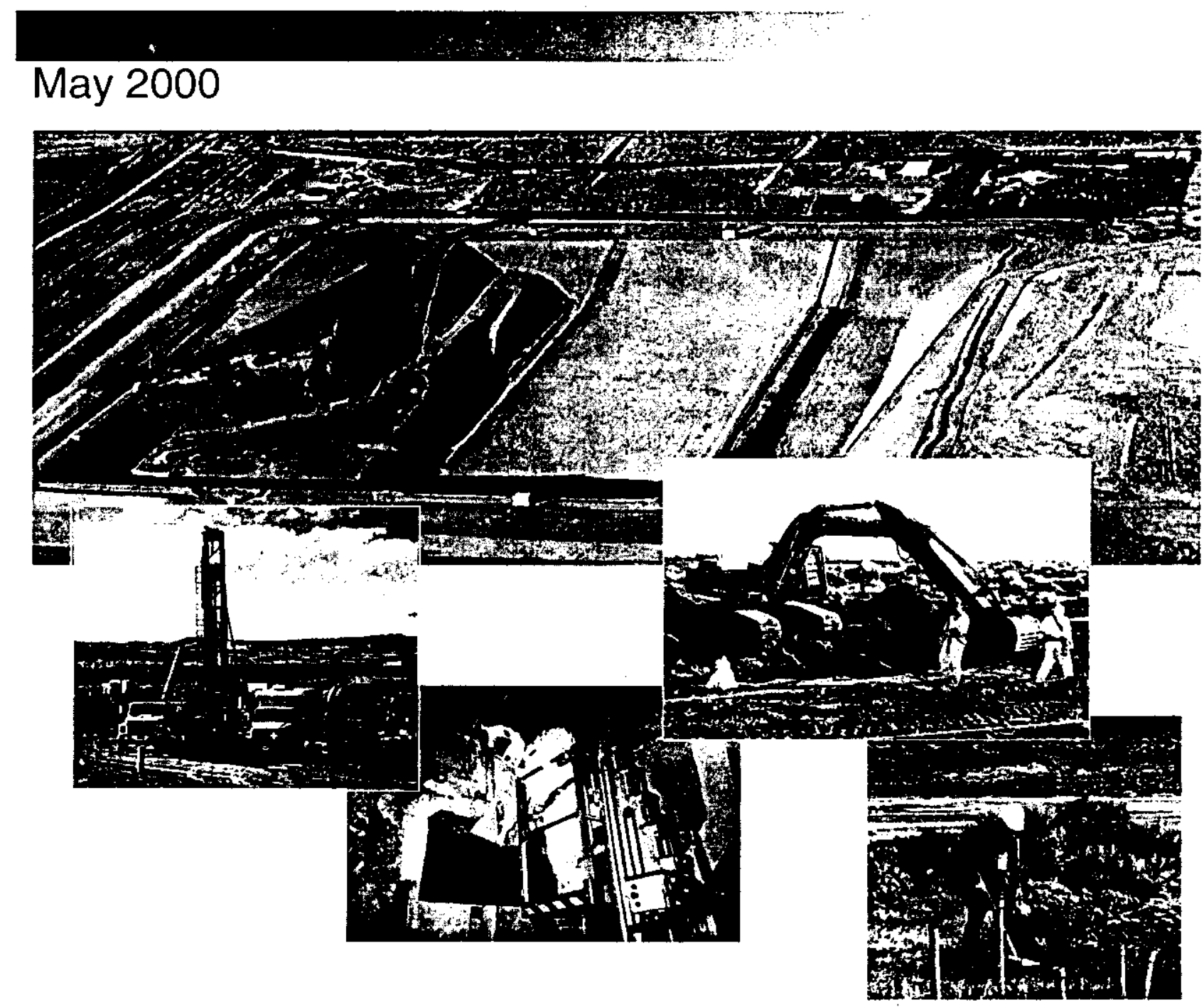

Foched on Progress...

Focused on Outcomes!

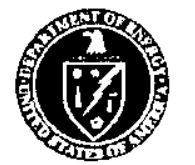

Department of Energy

Richland Operations Office

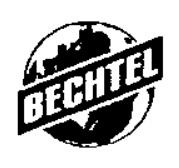

Bechtel Hanford, Inc.

Environmental Restoration Contractor 


\section{ENVIRONMENTAL MANAGEMENT PERFORMANCE REPORT ENVIRONMENTAL RESTORATION \\ MAY 2000}

\section{TABLE OF CONTENTS}

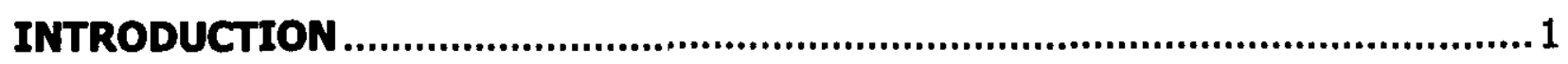

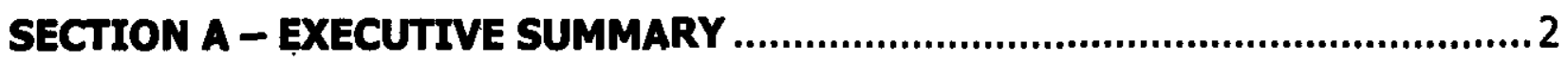

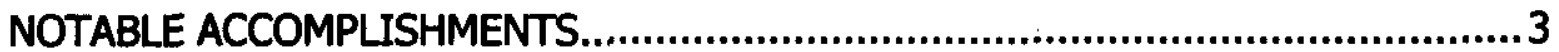

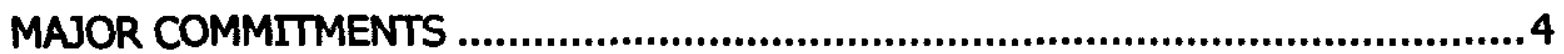

SAFETY/ISMS/CONDUCT OF OPERATIONS................................................. 5

REGULATORY/EXTERNAL/DOE-RL \& HQ ISSUES AND REQUESTS......................... 8

TOTAL COST/SCHEDULE OVERVIEW ..............................................................10

PERFORMANCE OBJECTIVES................................................................. 11

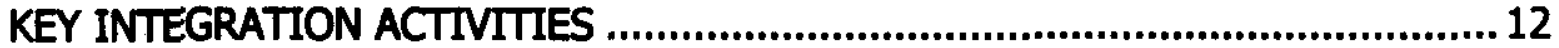

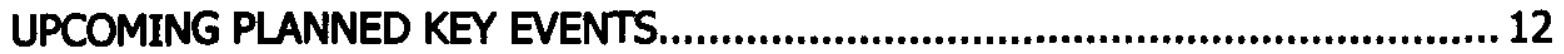

SECTION B - RESTORING THE RIVER CORRIDOR PROJECT SUMMARIES ..... 13

REMEDIAL ACTION AND WASTE DISPOSAL PROJECT ................................... 13

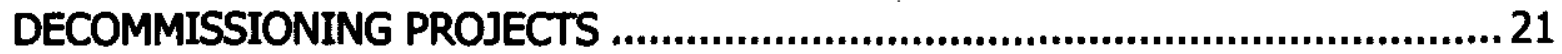

PROGRAM MANAGEMENT AND SUPPORT ..................................................... 26

SECTION C - TRANSITIONING THE CENTRAL PLATEAU PROJECT SUMMARIES............................................................................ 30

GROUNDWATER/VADOSE ZONE INTEGRATION PROJECT ...................................330

SURVEILLANCE/MAINTENANCE AND TRANSITION PROJECTS............................. 38 


\section{ENVIRONMENTAL MANAGEMENT PERFORMANCE REPORT ENVIRONMENTAL RESTORATION \\ MAY 2000}

\section{INTRODUCTION}

The monthly Environmental Restoration (ER) Environmental Management Performance Report consists of three sections: Section A - Executive Summary, Section B - Restoring the River Corridor Project Summaries, and Section C Transitioning the Central Plateau Project Summaries.

Section A - Executive Summary. This section provides an executive level summary of Bechtel Hanford, Inc.'s (BHI) performance information for the current reporting month and is intended to bring to Management's attention that information considered to be most noteworthy. The Executive Summary begins with a description of notable accomplishments that are considered to have made the greatest contribution toward safe, timely, and cost-effective cleanup. Major commitments are summarized that encompass Hanford Federal Facility Agreement and Consent Order (Tri-Party Agreement) milestones and FYOO Management Commitment milestones. Safety statistics are also included. Issues that require management and/or regulator attention and resolution status are addressed. Fiscal year-to-date ERC Project cost and schedule variance analysis is summarized. The Key Integration Activities section highlights site activities that cross contractor boundaries and demonstrates the shared value of working as a team to accomplish the work. The Executive Summary ends with a listing of major upcoming planned key events within a 90-day period.

Section B - Restoring the River Corridor. This section contains more detailed monthly activity information and performance status for the three projects within the 'Restoring the River Corridor' outcome. These three projects consist of the Remedial Action and Waste Disposal Project, Decommissioning Projects, and the Program Management and Support (PM\&S) Project.

Section C - Transitioning the Central Plateau. This section contains more detailed monthly activity information and performance status for the two projects within the 'Transitioning the Central Plateau' outcome. These two projects consist of the Groundwater/Vadose Zone (GW/VZ) Integration Project and the Surveillance/Maintenance and Transition (SM\&T) Projects.

Information in this report is identified with a green, yellow, or red text box used as an indicator of the overall status. Green indicates work or issue resolution is satisfactory and generally meets or exceeds requirements; yellow indicates that significant improvement is required; and red indicates unsatisfactory conditions requiring immediate corrective actions. 
ENVIRONMENTAL MANAGEMENT PERFORMANCE REPORT

ENVIRONMENTAL RESTORATION

MAY 2000

\section{Section A: Executive Summary}




\section{ENVIRONMENTAL MANAGEMENT PERFORMANCE REPORT ENVIRONMENTAL RESTORATION \\ MAY 2000}

\section{SECTION A - EXECUTIVE SUMMARY}

\section{Financial / Performance measures data as of month-end March.}

All other data as of April 20, unless otherwise noted.

\section{NOTABLE ACCOMPLISHMENTS:}

Approximately $90 \%$ of the underground piping in $100 \mathrm{H}$ Area has been removed. Baseline change proposals $(B C P)$ are being prepared to address additional contaminated plumes being found in both $100 \mathrm{D}$ and $\mathrm{H}$ Areas.

The 100 F Area design package was completed in mid-April.

The 100-NR-1 remediation contract was awarded on April 13. Soil remediation is scheduled to begin in July.

$R L$ issued a letter to the regulators on March 29 declaring completion of Tri-Party Agreement Milestone M-16-08B, Complete Remediation and Backfill of 19 Liquid Waste Sites in the 100-BC-1 and 100-BC-2 Operable Units, on February 25, five weeks ahead of the March 31 milestone date. All scheduled work has been completed at the $100 \mathrm{~B} / \mathrm{C}$ Area. Only pipeline and burial ground remediation remains to be completed.

The $D$ and H Reactor's Engineering Evaluation/Cost Analysis (EE/CA) and the D Reactor Auditable Safety Analysis (ASA) were submitted to RL in March. RL review is in progress.

The F Reactor safe storage enclosure (SSE) pourback subcontractor began mobilization and preparation for the valve pit work.

Four waste minimization targets were completed in conjunction with the waste reduction incentives: 1) redeployment of a concrete crusher to Ohio, 2) recycled excessed absorbents to another Environmental Restoration (ER) project, 3) recycled flatbed trailer and generator, and 4) recycled 1,100 drum overpacks.

All five groundwater pump and treat systems operated at or above the planned $90 \%$ availability levels through March.

The FY 2000 In Situ REDOX Manipulation (ISRM) well installations were completed on April 24 in the $100 \mathrm{D}$ Area. Sixteen wells were drilled and installed to planned depth.

The GroundwaterNadose Zone (GWNZ) draft Science and Technology Roadmap was submitted to RL on April 14. The revision of the Roadmap includes the risk technical element and provides the basis for Fy 2002 workscope.

The peer review of the System Assessment Capability (SAC) Revision O Design Document and Detailed Software Design Document were completed.

Removal of legacy waste at the KE Reactor is approximately $90 \%$ complete. Legacy waste removal at KW Reactor is approximately $45 \%$ complete.

Washington Department of Health approved the final design package for the water treatment plant replacement system at the $N$ Reactor site. The subcontractor continued installation of the new piping system. 


\section{ENVIRONMENTAL MANAGEMENT PERFORMANCE REPORT \\ ENVIRONMENTAL RESTORATION \\ MAY 2000}

\section{MAJOR COMMITMENTS:}

\section{Tri-Party Agreement Milestones}

Twelve Tri-Party Agreement milestones have been completed through March, all ahead of schedule. RL issued a letter to the regulators on March 29 declaring completion of Tri-Party Agreement Milestone M-16-08B, Complete Remediation and Backfill of 19 Liquid Waste Sites in the 100-BC-1 and 100-BC-2 Operable Units, on February 25, five weeks ahead of the March 31 milestone date.

\begin{tabular}{|c|c|}
\hline Total Tri-Party Agreement Milestones Due in FYOO & 16 \\
\hline Total Planned Through March & 12 \\
\hline Total Completed Through March & 12 \\
\hline
\end{tabular}

\begin{tabular}{|l|c|}
\hline Remaining Milestones to be Completed in Froo & $\mathbf{4}$ \\
\hline Forecast Ahead of Schedule & 1 \\
\hline Forecast On Schedule & 3 \\
\hline Unrecoverable & 0 \\
\hline
\end{tabular}

\section{High Visibility Project Milestones:}

Transmit Update of the Vadose Zone Science and Technology Roadmap (PBS VZO1) due April 30.

Status: Draft was provided to DOE on April 14.

Complete Installation of the Wells and Initiate Injection of the Barrier for Phase II of the In Situ REDOX Manipulation Project (PBS ERO8) due September 30.

Status: Forecasted to be complete by September 30. (Well installation completed on April 24.)

Complete the Semi-Annual GroundwaterNadose Zone Report (December 1999 - March 2000) due May 31.

Status: Forecasted to be completed by May 31.

\section{Other Major Milestones:}

Develop and Implement Integrated Safety Management (ISM) due September. 30.

Status: On schedule. 


\section{ENVIRONMENTAL MANAGEMENT PERFORMANCE REPORT \\ ENVIRONMENTAL RESTORATION \\ MAY 2000}

\section{SAFETY/ISMS/CONDUCT OF OPERATIONS (Total ER Contract):}

ERC First Ald Case Rate per 200,000 Hours

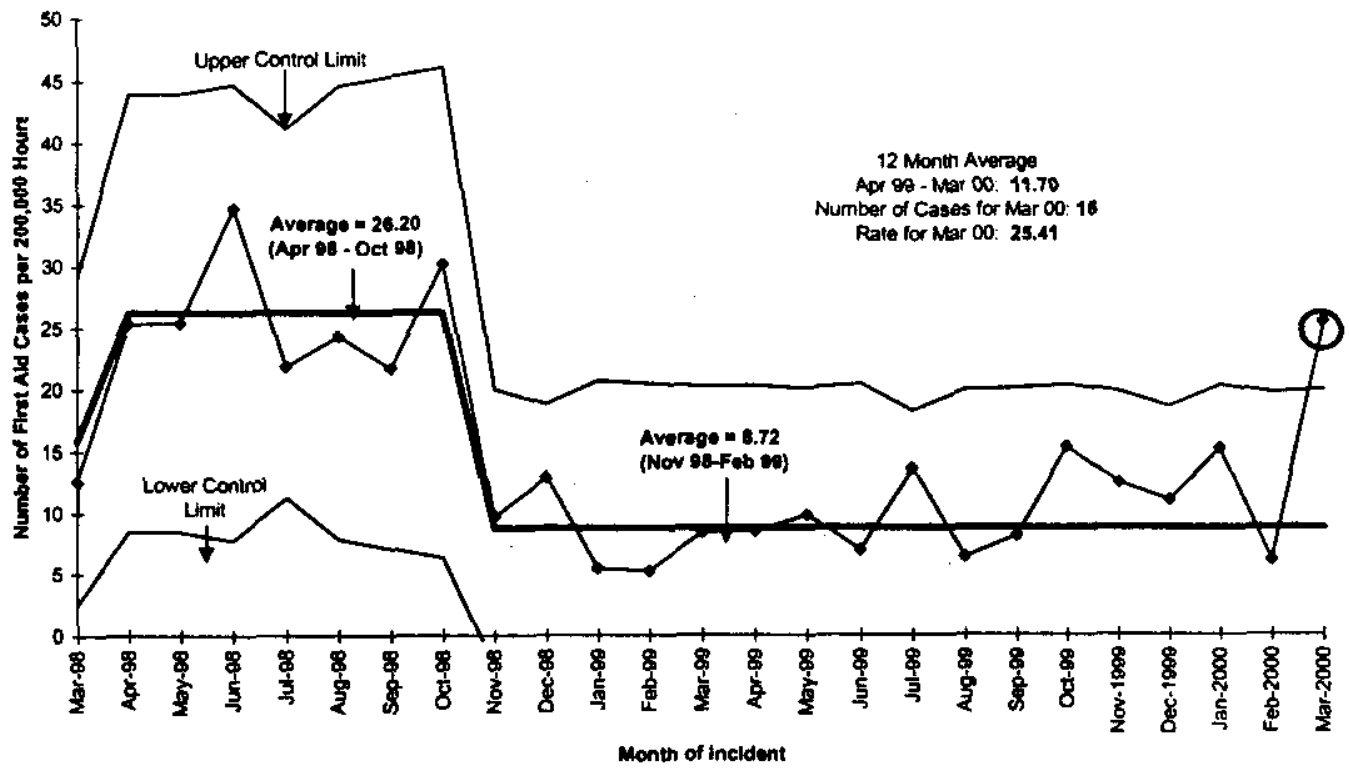

The ERC expertenced a sienificant increase in firct aid cases during March primarily due to strains and abrasions.

ERC Recordablo Caso Rato/200,000 Mours

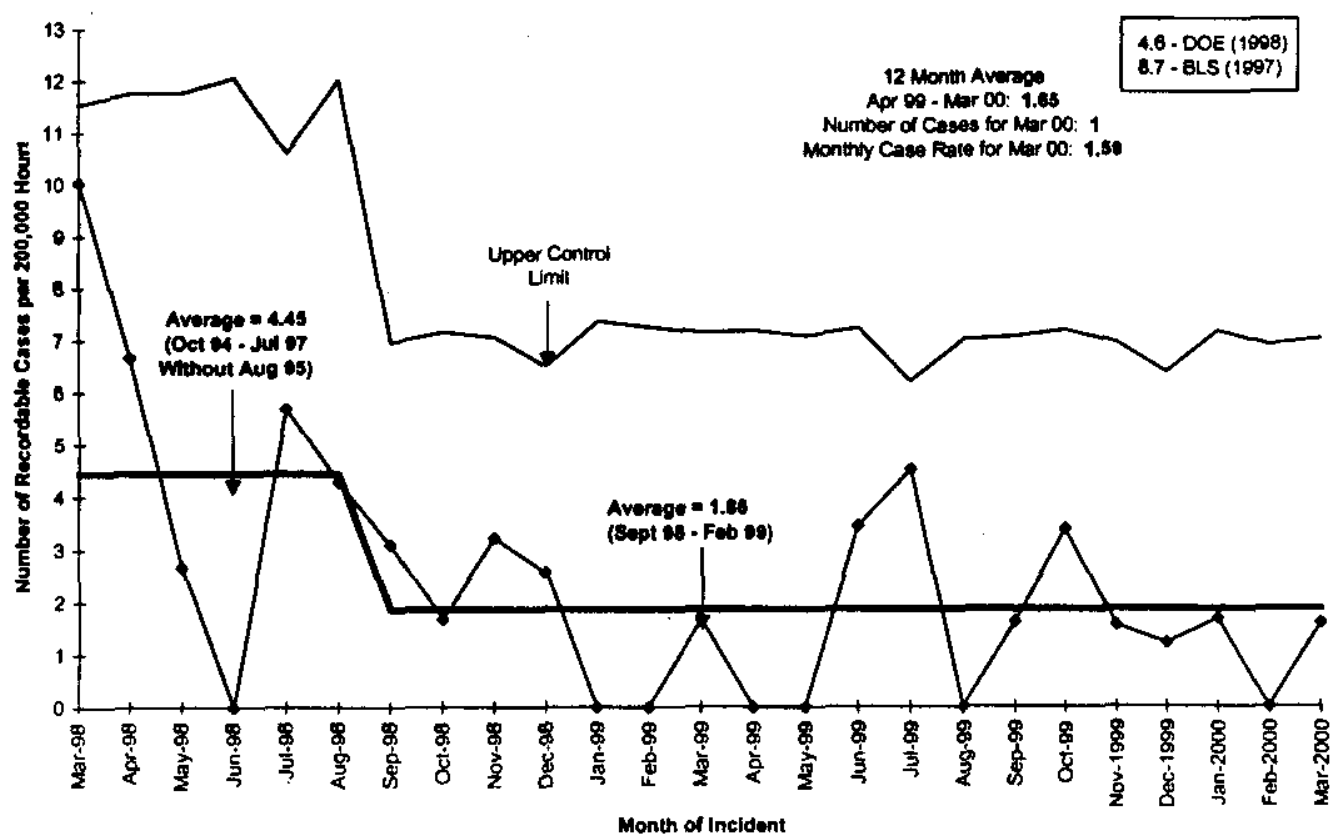

The ERC Recordable Case Rate has been below the-baseline average for five consecutive months. 


\section{ENVIRONMENTAL MANAGEMENT PERFORMANCE REPORT ENVIRONMENTAL RESTORATION \\ MAY 2000}

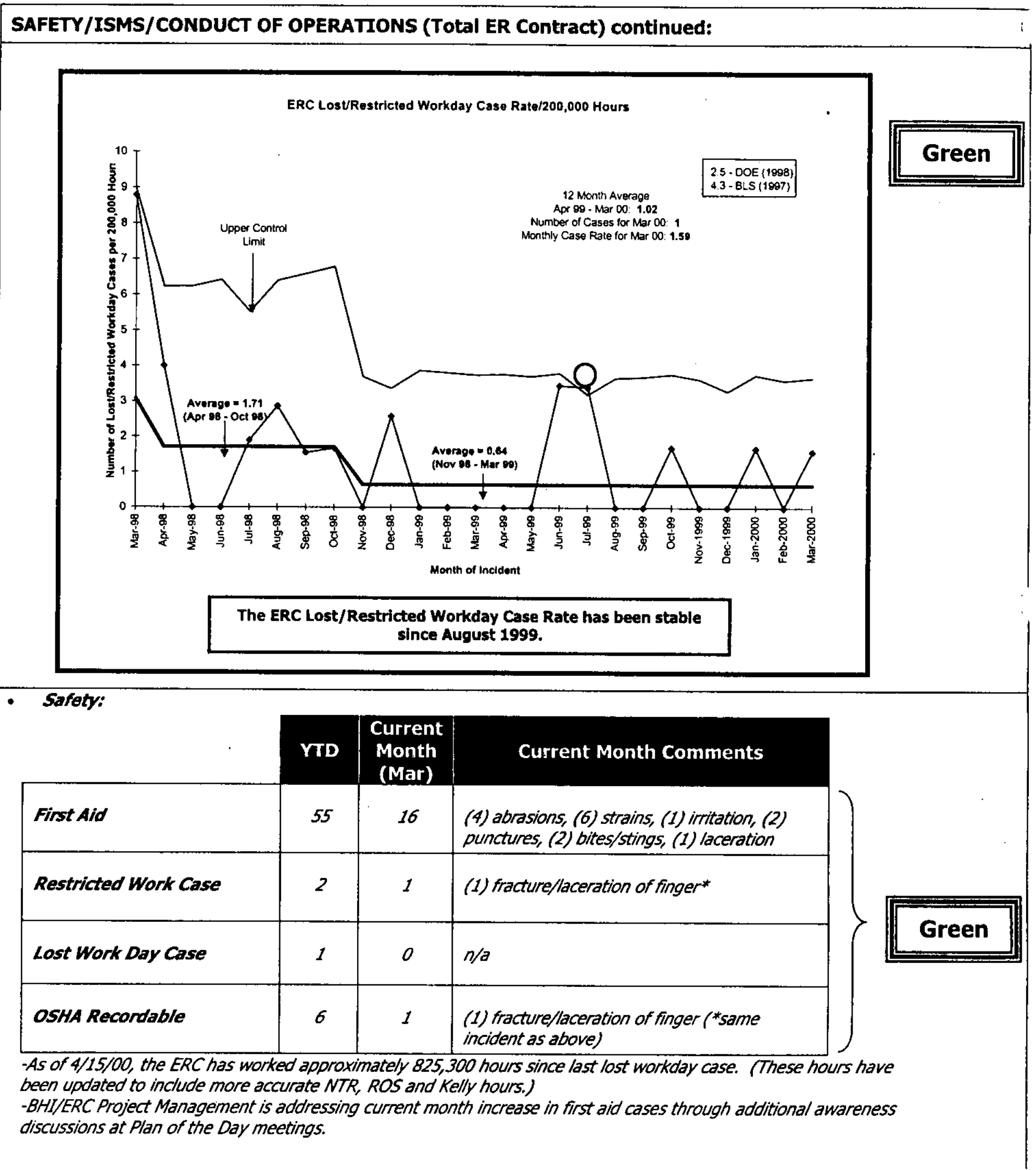




\section{ENVIRONMENTAL MANAGEMENT PERFORMANCE REPORT ENVIRONMENTAL RESTORATION \\ MAY 2000}

\section{SAFETY/ISMS/CONDUCT OF OPERATIONS (Total ER Contract) continued:}

- ISMS:

DOE EM Perfomance Agreement: Develop and implement Integrated Safety Management (ISM) September 30.

Status: On March 23, the DOE ISMS Verification Team Leads met with BHI Senior Management to debrief them on the results of the verification. They also met with DOE-RL Senior Management later that day and made a presentation to them on their conclusions as to the status of ISMS Implementation at BHI.

The Verification Team recommended that Keith Klein approve the BHI ISM Description Document (BHI-01199) after incorporation of the following:

- Descriptions of the Detailed Work Planning, Results Management Team, and Baseline Change Proposal budgeting and business planning processes;

- measures to monitor and evaluate system effectiveness; and

- discussion of line management roles and responsibilities in a project matrix organization.

The Verification Team also recommended that Keith Klein consider the ERC ISMS to be adequately implemented. The team identified five opportunities for improvement that serve as a focal area to further strengthen and continuously improve the ERC ISMS implementation.

The Verification Team also identified several "Noteworthy Practices" which they cited as evidence of a commitment to ISMS that should be reinforced and continued.

- Conduct of Ops:

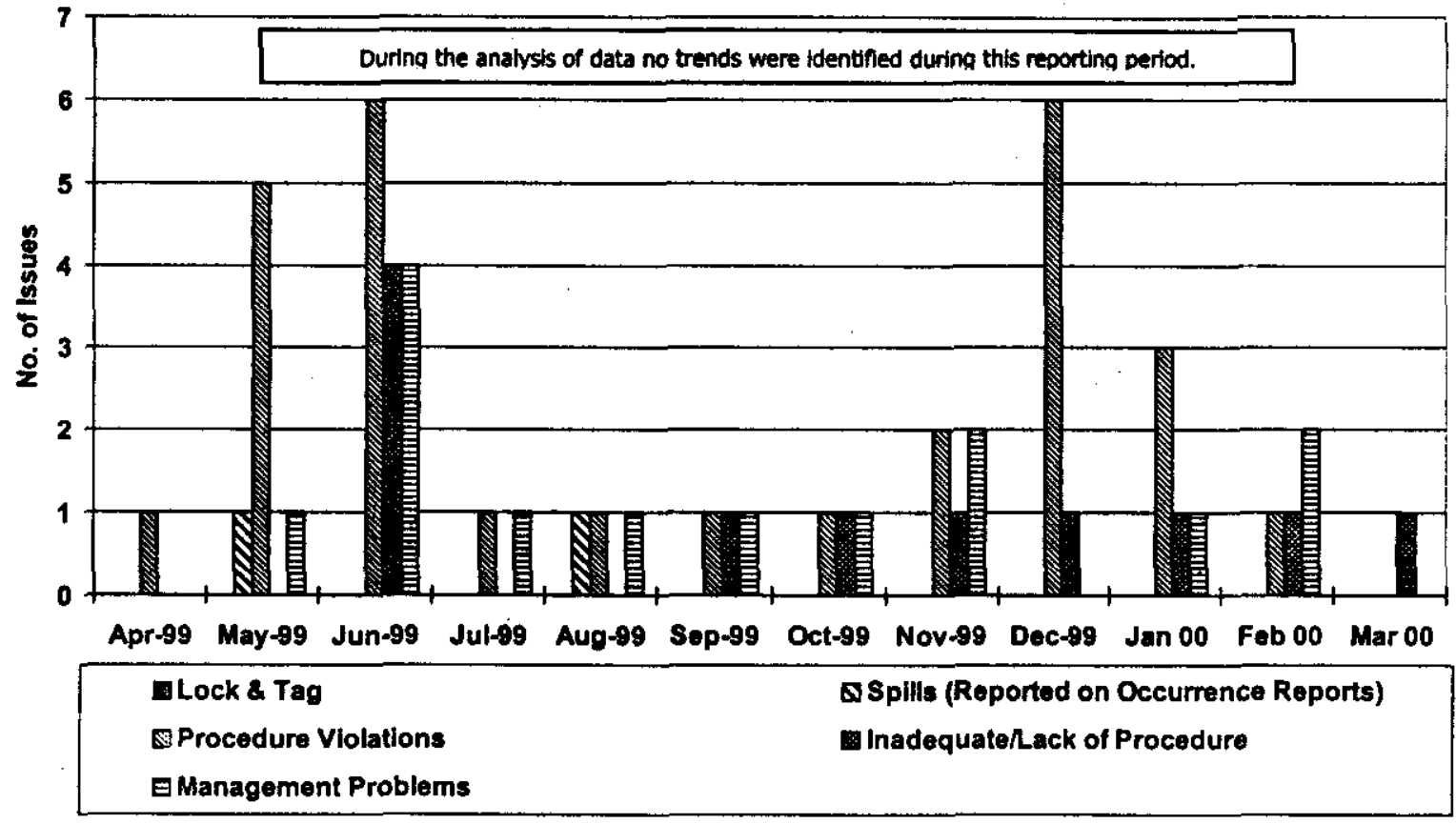

ERC-CATS (Computer-Aided Tracking System) Trend Data 4/1/99 through 3/31/00

\begin{tabular}{|c|c|c|c|c|c|c|c|c|c|c|c|c|}
\hline & Apre0 & Moyele & Junet & Jwen & Aug $=0$ & Supen & atep & Novele & $D_{0<-\infty 8}$ & $\operatorname{dan} \theta 0$ & $F \infty \infty \infty$ & $\operatorname{mar} \infty$ \\
\hline Lock \& TEP & 0 & 0 & 0 & 0 & 0 & 0 & 0 & 0 & 0 & 0 & 0 & 0 \\
\hline $\begin{array}{l}\text { Spllls (Reported on } \\
\text { Occurtence Reports) }\end{array}$ & 0 & 1 & 0 & 0 & 1 & 0 & 0 & 0 & 0 & 0 & 0 & 0 \\
\hline Procadure Volations & 4 & 5 & $\div$ & 1 & 1 & 9 & $\frac{1}{1}$ & $\frac{5}{2}$ & 5 & $\frac{\pi}{3}$ & 1 & 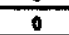 \\
\hline $\begin{array}{l}\text { Inadequaten ack of } \\
\text { Procedure }\end{array}$ & 0 & 0 & 4 & 0 & 0 & 1 & 1 & 1 & 1 & 1 & 1 & 1 \\
\hline Monzogoment Problems & 0 & 1 & 4 & 1 & 1 & 1 & 1 & 2 & $\div$ & 1 & $\frac{\pi}{2}$ & 0 \\
\hline
\end{tabular}

Each potential trend is reviewed and evaluated for impact on the project, and then given the appropriate level of attention based on a graded approach. 


\section{ENVIRONMENTAL MANAGEMENT PERFORMANCE REPORT ENVIRONMENTAL RESTORATION MAY 2000}

SAFETY/ISMS/CONDUCT OF OPERATIONS (Total ER Contract) continued: March Conouct of Ops Issues;

Inadequate/Lack of Procedure: Condition Description: The Craft Supervisor was obsenving pipe removal activities in the 233-S " Plutonium Concentration Facility Viewing Room. This is a posted High Contamination Area (HCA) and everyone in the room was wearing a double layer of anti-contamination clothing. The Craft Supervisor was also wearing an extra set of puncture resistant gloves. While applying duct tape over the end of a recently cut pipe, the Craft Supervisor's right hand contacted a sharp piece of metal on the pipe which punctured his gloves and resulted in a small cut to the palm of his hand.

Corrective Action Plan: (1) Revise the Activity Hazard Analysis (AHA) to impose additional engineered controls. Use padded silver metallic tape to cover sharp surfaces instead of duct tape. Purchase and use plastic pipe caps where size and configuration permits. (2) Revise the AHA to impose an additional administrative control that personnel performing work involving sharp objects, that cannot be restrained, will work in teams of two. One person will hold the object while the other applies tape to the sharp surface. This will allow taping without physically contacting sharp surfaces. (3) Revise the AHA to impose an additional administrative control for the personnel performing work involving sharp objects that restricts the use of thin (5-8mil) blue nitrile gloves and specifies glove combinations for direct cutting inside a radiological containment. (4) Investigate other gloves looking for combinations that provide improved puncture resistance while permitting worker dexterity and tool control. (5) As recommended by the workers, re-emphasize with the Field Superintendent and Craft Supervisor the requirement to hold a Plan of the Day Presentation, per BHI-FS-01, Field Support Administration, Procedure 1.10, Shift Tumover, Section 5.2.5 prior to the afternoon entry to discuss work performed and problems encountered during the morning. (6) Brief the entire 223-S permanently assigned project team on the details of this occurrence and the planned corrective actions. (7) Develop a lessons learned on this event and provide it to the ERC Lessons Learned Coordinator for appropriate circulation.

\section{REGULATORY/EXTERNAL/DOE-RL \& HQ ISSUES AND REQUESTS:}

Site Wide Senlority (SWS): Current BHI/THJ manual staffing totals 268 personnel. Approximately 225 position openings will become available within the Fluor Hanford organization during FY 2000. Currently, 53 BHI/THI personnel have applied for transfer through the LAMP (Labor Assets Management Program) Process. Continued loss of personnel will result in additional costs and potential impacts to critical work path activities.

Status: Lamping of ERC personnel has begun. For the months of January through March, 23 personnel have transferred to Fluor Hanford. A site-wide strategy is required to maintain trained and critical resources on ER work. Lamping of personnel has resulted in additional costs associated with the training of new personne/ without compensation from the receiving organization.

Funding: FY 2001 and FY 2002 ER funding (target) levels are below minimum compliance requirements. Submitted FY 2001 President's budget assumes ER funding target at $\$ 143 \mathrm{M}$ (revised IPL now reflects $\$ 141.9 M)$. While this funding level maintains a number of significant activities supporting site cleanup goals, it is far short of maintaining compliance with TPA other Regulatory commitments for the near term and especially beyond FY 2001. The recently submitted budget reflects a funding target for FY 2002 of $\$ 140.8 \mathrm{M}$, which is again significantly short of supporting minimum compliance requirements and for FY 2002 and beyond.

Activities, not funded, that need to be addressed in FY 2001 and FY 2002 include:

- 200 Area Characterization

- Reactor ISS

Status: Maintain current TPARegulatory commitments in FY 2000; develop impacts associated with directed funding targets for FY 2001 and FY 2002, and support DOE budget submittals and presentations, including discussions with Regulators on projected future shortfalls and prioritization of allocated funding, including adjustments to support the Detailed Work Planning update (DWP) beginning in June. 


\section{ENVIRONMENTAL MANAGEMENT PERFORMANCE REPORT ENVIRONMENTAL RESTORATION \\ MAY 2000}

REGULATORY/EXTERNAL/DOE-RL \& HQ ISSUES AND REQUESTS continued:

Emerging Work: Emergence of priority work is impacting the ERC's ability to initiate stretch and superstretch work activities.

Status: The "emerging work" issue was one of three issues included in the letter, M. C. Hughes to' $K$. A. Klein, 4/03/00, "Bechtel Hanford, Inc. Performance Incentive Impacts", CCN 078071 . The other issues identified in that letter were (1) unclear RL organization, roles and responsibilities for administration of BHI's PI administration and (2) methodology for implementing superstretch PI not being fully defined. To date, no response has been received from DOE Management. 


\section{ENVIRONMENTAL MANAGEMENT PERFORMANCE REPORT ENVIRONMENTAL RESTORATION \\ MAY 2000}

TOTAL COST/SCHEDULE OVERVIEW (Total ER Contract):

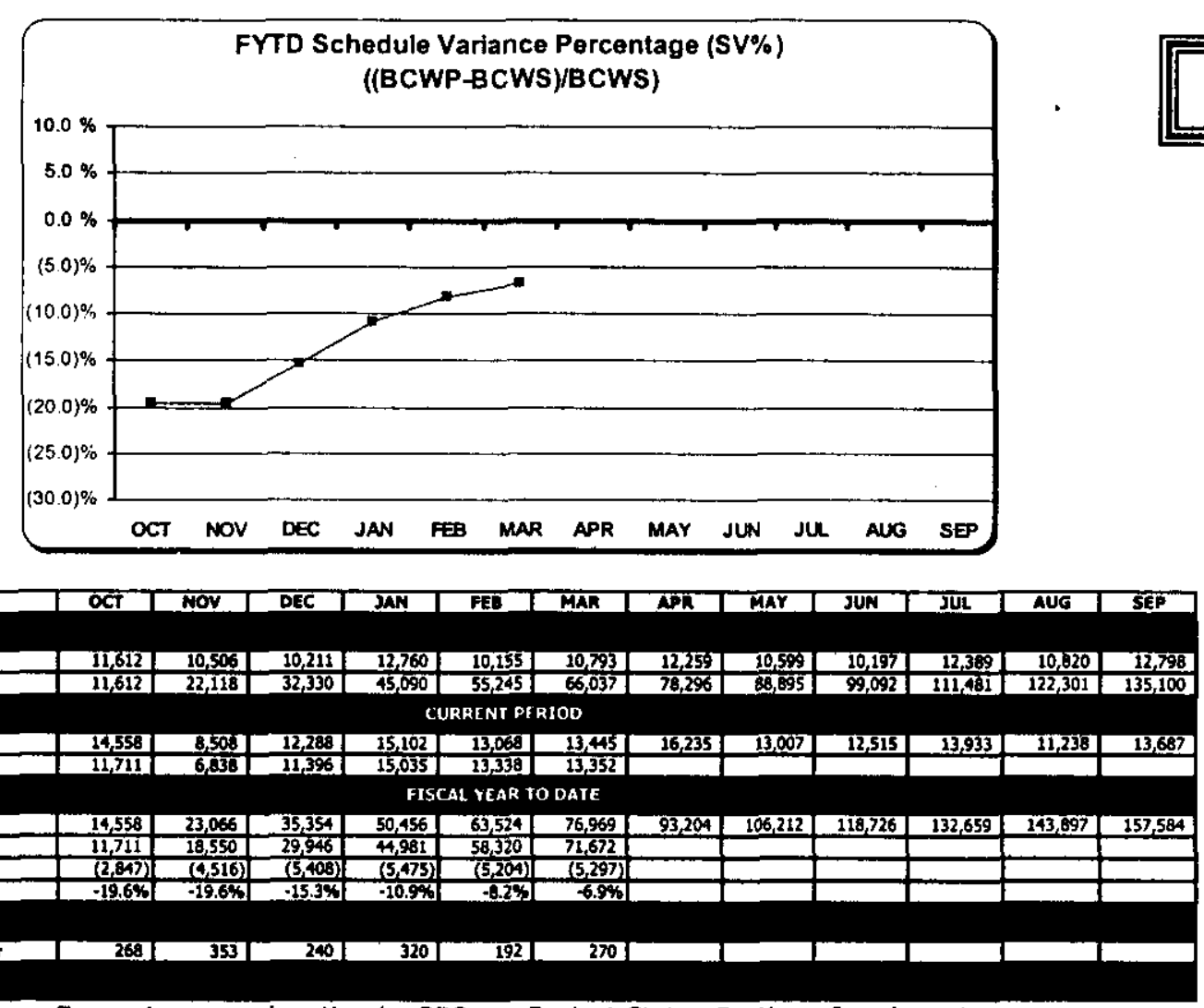

For variance explanation by PBS see Project Status Section of each project.

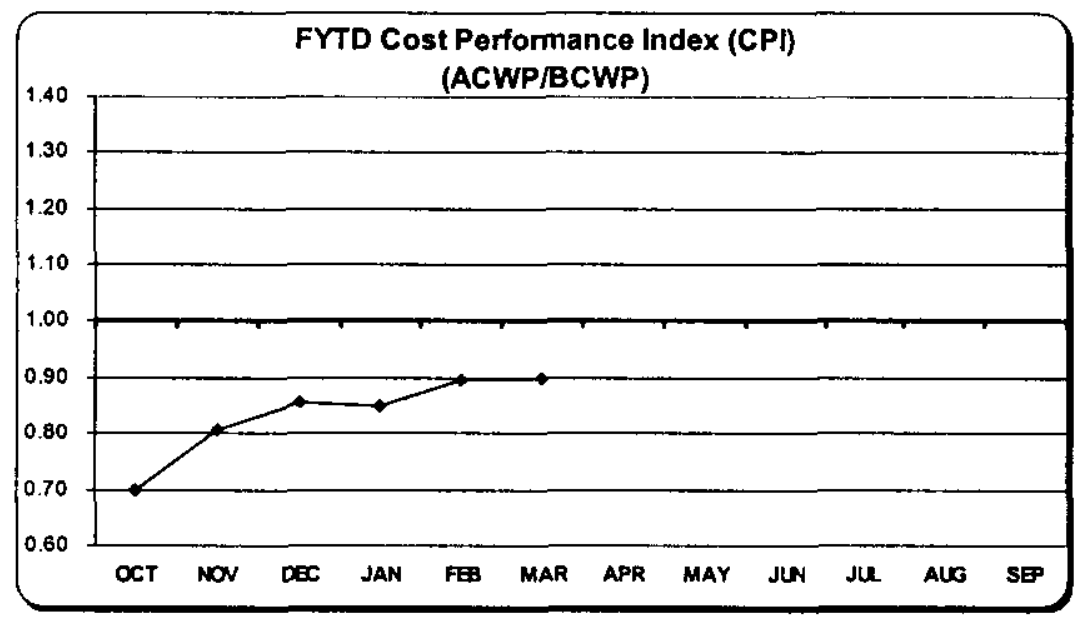

Desired performance is 1.0 or less.

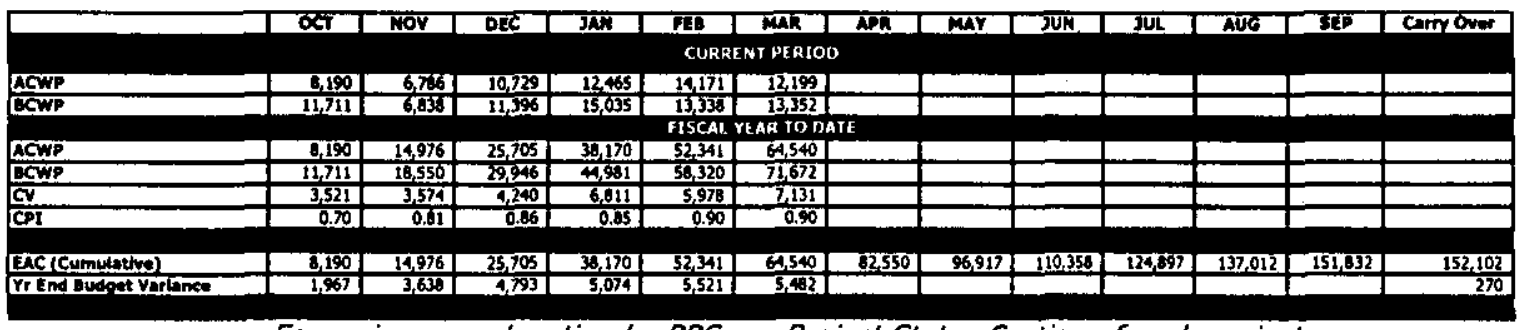

For variance explanation by PBS see Project Status Section of each project. 


\section{ENVIRONMENTAL MANAGEMENT PERFORMANCE REPORT ENVIRONMENTAL RESTORATION \\ MAY 2000}

TOTAL COST/SCHEDULE OVERVIEW (Total ER Contract) continued:

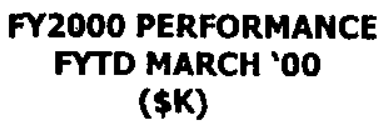

Green

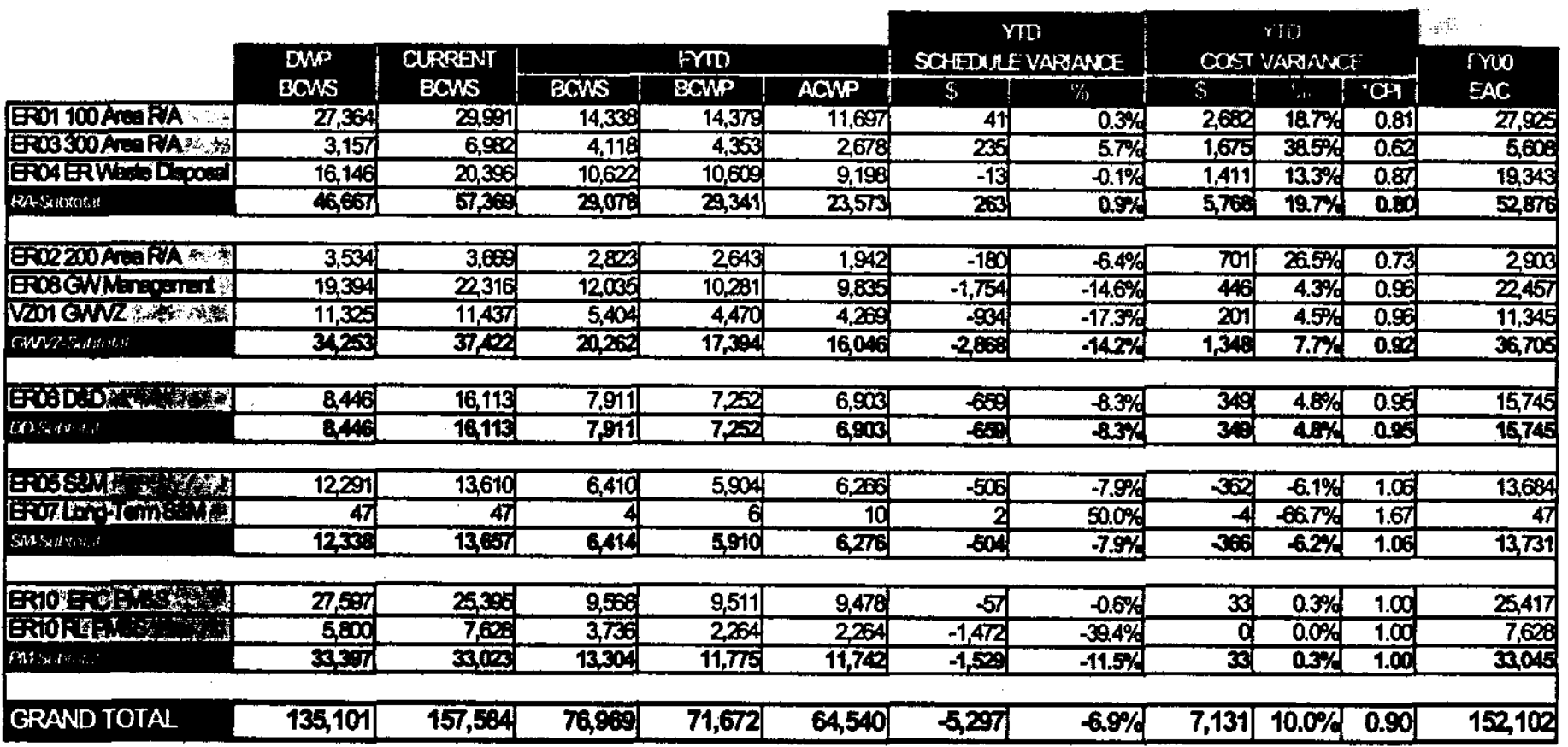

${ }^{*} C P J=A C W P / B C W P$

\section{Cost/schedulestatusi}

Cast Variance: At the end of March, the ER Project had performed \$71.7M worth of work, at a cost of \$64.5M. This accounts for a favorable cost variance of $\$ 7.1 \mathrm{M}(10 \%)$. The positive cost variance is attributed to site excavation savings reduced contract award amounts, borehole drilling and test pit trenching costs less than planned (due to efficiencies), and Fr 1999 year-end accrual reversals.

Schedule Variance; The ER Project is $\$ 5.3 \mathrm{M}$ (-6.9\%) behind schedule for March. The negative schedule variance is attributed to delayed Integration Project science and technology (S\&T) activities; undetermined Integration Project subpane/ schedules; delayed groundwater well maintenance (resin regeneration/purchase) and monitoring; 233-S Facility loadout hood waste removal (awaiting waste container procurement), and roof duct removal, sampling, and analysis; $224 B$ facility inspection/survey delayed due to inoperable exhaust system repairs; and late billings for sitewide assessments.

\section{PERFORMANCE OBJECTIVES:}

River Corridor Inituative (Complete remediation of 60 sq. miles, including Hanford townsite): Initiative is currentty identified as a superstretch item, with an approximate value of \$5.0M. High visibility public access opportumlties; also a superstretch item (bike trail, raad to B Reactor, and baat ramp at Hanford townsite). Feasibility plan completed and is in review.

Status: Preparing presentation of results for AMEW review targeted for mid-March. 


\section{ENVIRONMENTAL MANAGEMENT PERFORMANCE REPORT ENVIRONMENTAL RESTORATION \\ MAY 2000}

\section{KEY INTEGRATION ACTIVITIES:}

BHI supported Fluor Hanford in the development of a Baseline Change Request (BCR) to prepare an accelerated closure plan for the 300 Area. Walkdowns have been initiated. The project team is continuing to develop cost and schedule information in support of the BCR development. Modeling activities are. scheduled to begin the first week of May.

\section{UPCOMING PLANNED KEY EVENTS:}

Tri-Party Agreement Milestone M-93-05, Issue B Reactor Phase II Feasibility Study Engineering Design Report for Public Comment, due June 30. 


\section{Richland Operations Office Environmental Restoration \\ Environmental Management Performance Report}

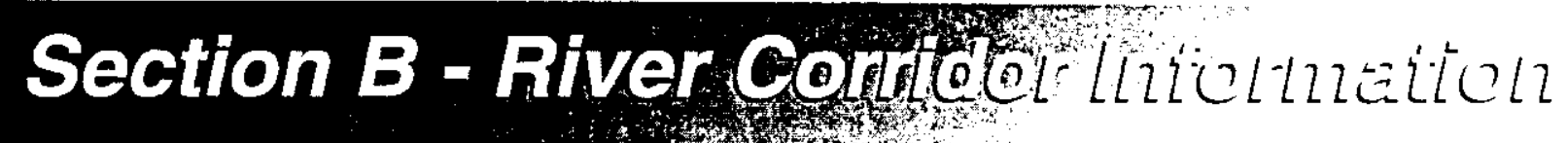

May 2000

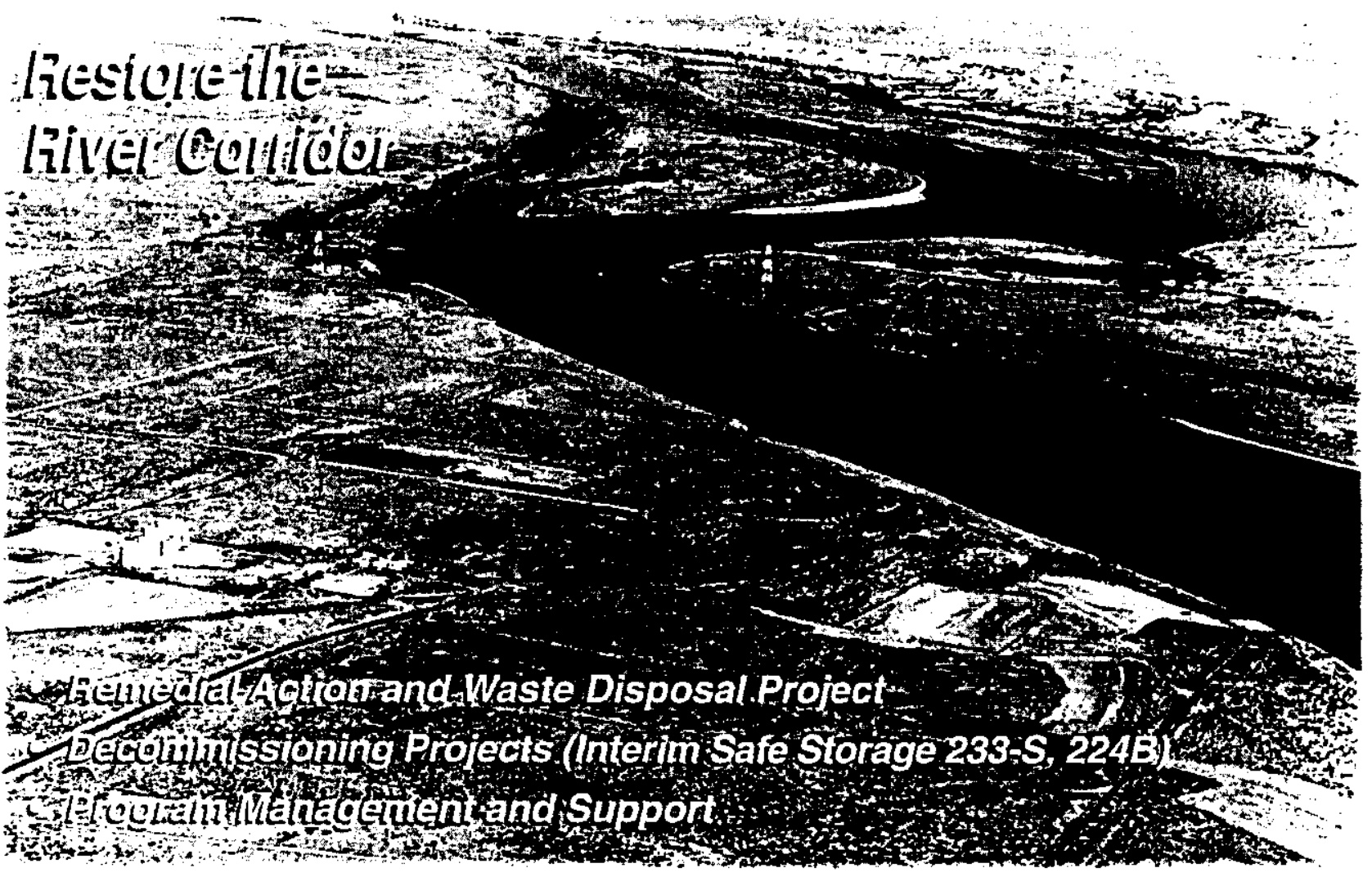

Focused on Progress...

Focused on Outcomes!

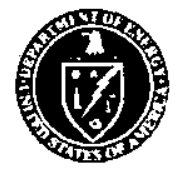

Department of Energy

Richland Operations Office

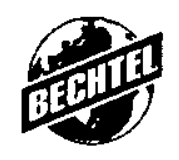

Bechtel Hanford, Inc.

Environmental Restoration Contractor 
ENVIRONMENTAL MANAGEMENT PERFORMANCE REPORT

ENVIRONMENTAL RESTORATION

MAY 2000

\section{Remedial Action and Waste Disposal Project




\section{ENVIRONMENTAL MANAGEMENT PERFORMANCE REPORT ENVIRONMENTAL RESTORATION \\ MAY 2000}

\section{SECTION B - RESTORING THE RIVER CORRIDOR}

Financial / Performance Measures data as of month-end March.

All other data as of April 20, unless otherwise noted. Remedial Action \& Waste Disposal Project (RAWD):

\section{ACCOMPLISHMENTS: RAWD}

ERDF Transportation and Operations: During March, shipments totaling 62,880 metric tons (69,314 tons) of contaminated waste were transported to the ERDF. 308,022 metric tons (339,538 tons) have been received in FY 2000. To date, 2,034,998 metric tons (2,243,213 tons) of material have been received and placed in the disposal facility. To date, waste transport has drivers driven over 3,780,000 accident free miles.

In preparation for receiving N-Cribs and K-Basins waste, the ERDF safety analysis is being revised to incorporate radionuclides that are unique to these two waste streams.

The ERDF completed its second leachate pumping campaign on March 28. In this transfer, a total of 117,000 gallons was pumped to the Liquid Processing Facility in the 200 East Area.

The RAWD is upgrading its overall waste packaging quality and safety effort. This inc/udes container maintenance, tarp and bungee inspection and replacement, and proper preparation of containers for shipping. Substantial progress is being made in all areas.

100 D Area Remedial Action: Excavation of one waste site 100-D-52 was completed and backfill of six Group 2 high priority waste sites was completed.

Pipeline remediation work included: asbestos abatement; removal of small diameter pipes near D Reactor; concrete breaking on encasements, expansion boxes, and pipe anchors; and pipe cutting and size reduction for shipment to ERDF.

Stockpiled material from the 100-D-12 waste site was identified as having chromium contamination and was shipped to ERDF. Also, plumes have been identified and a BCP for removing the additional material is in process.

Excavation of plumes from three D Area waste sites were completed. The pipeline plume west of the basin has grown considerably and a separate BCP is being prepared for the excavation activities and to relocate an existing power pole and install one additional power pole.

100 B/C Remedial Action: Complete.

$100 \mathrm{H}$ Area Remedial Action: Approximately $90 \%$ of the baseline scope underground piping in the 100$H$ Operable Unit has been removed. $A B C P$ is in process to remove an additional 8,750 tons of contaminated soil (second plume encountered on the pipeline removal work scope).

The baseline scope of the 116-H-7 Retention Basin excavation was completed. $A$ BCP is in process to remove 48,720 tons of additional plume material. Demolition of the concrete structures (approved BCP) encountered at the 100-H-24 Substation was completed.

Verification sample results received for the 1607-H-4 Septic Tank indicate Semi-volatile compounds (SVOCS) results that exceed the Remedial Action Goals (RAGs). A BCP is in process to remove an additional 1,250 tons of material.

Lead contamination was detected in verification samples collected from one of the H Area septic tanks. The project plans to perform additional lead analysis to ensure that lead concentrations detected in the excavation sidewalls and foor do not extend to the groundwater.

100 F Area Remedial Action: The 100 F Operable Unit design package was completed in mid-April.

Cultura/ Resource investigations at the 100 F Area Operable Unit were completed. 


\title{
ENVIRONMENTAL MANAGEMENT PERFORMANCE REPORT ENVIRONMENTAL RESTORATION \\ MAY 2000
}

\begin{abstract}
ACCOMPLISHMENTS continued: RAWD
300 Area Remedial Action: Drums continue to be exhumed from Landfill 1A. Most of the drums are empty and are crushed and sent to ERDF.

Additional contamination has been found in the South Process Pond. What was thought to be an increase of 5,000 tons is now estimated to be at 24,925 US tons. The increase is associated with contaminated soil discovered in the interior of the southeast dike that was assumed to be non-contaminated. Test pits were dug to define the extent of this latest plume.

Contamination in the south dike of the South Process Pond extends into the area surrounding an existing power pole to minimize power disruption. A plan has been developed to hold the pole in place with a boom truck while incrementally excavating and backfilling around the base of the pole. Field screening will be used to confirm cleanup criteria are met before each portion of backfill is placed and compacted. This plan has been reviewed with EPA. The overhead power lines will be temporarily taken out of service during these remediation activities.

100-MR-1 Remediation: Soil remediation at $100 \mathrm{~N}$ is scheduled to begin in July to meet the requirements of the Hanford Site RCRA permit. The contract was awarded on April 13 to Foster Wheeler.

100-NR-1 TSO Sites Design: Regulator comments were received on the draft Sampling and Analysis Plan for NR-1 TSD sites. Work on the Remedial Design Report/Remedial Action Workplan continues.

100 Area Assexsment: Comments on Rev. B of the Proposed Plan were received from DOE-HQ and EPA Region 10. Fact sheet preparation is underway in support of Public Comment Period scheduled for May.
\end{abstract}

\section{SAFETY/ISMS/CONDUCT OF OPS: RAWD}

See Crass-Cutting Package.

\section{BREAKTHROUGHS/OPPORTUNITIES FOR IMPROVEMENT: RAWD}

Waste Minimiation 126-F-1 Ash Plt; The project deploved two off-the-sheff technologies (geo-probe and sodium iodide detector) to perform in-situ characterization that resulted in 50\% reduction in waste site volume. Preliminary cost savings is estimated at \$5M.

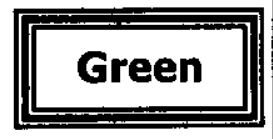

Status: The final report on the 126-F-1 Ash Pit was provided to the Return-on-investment (ROI) Program mid-April. Planning is underway to develop a sampling and analysis approach to support close-out verification sampling for the south portion of the 126-F-1 Ash Pit.

\section{LONG-TERM (6 MONTHS PLUS) IMPORTANT ITEMS: RAWD}

300-FF-2: Work is ongoing to prepare decision documents for the public review period scheduled for late May. Ecology has issues with the Preliminary Remediation Gaals (PRG's) being developed for 300-FF-2. EPA, who supports the PRG'S, will be addressing issues with Ecology with support from RL.

Stutus: The Draft B Focused Feasibility Study and Proposed Plan for the 300 FF-2 Operable was transmitted for review on April 21. Comments are expected back by mid-May. Issues related to Preliminary Remediation Gaals should be addressed by this time.

100 Area Burial Grounds: Approval of the ROD is planned by August 30.

Status: Currently tracking on schedule; no issues.

\section{MAJOR COMMITMENTS (FISCAL YEAR PLUS 6 MONTHS): RAWD}

- DOE Secretarial:

None identified at this time.

- DOE EM Performance Agreement:

None identified at this time. 


\section{ENVIRONMENTAL MANAGEMENT PERFORMANCE REPORT ENVIRONMENTAL RESTORATION \\ MAY 2000}

\begin{tabular}{|c|c|c|c|c|}
\hline \multicolumn{5}{|c|}{ MAJOR COMMITMENTS (FISCAL YEAR PLUS 6 MONTHS) continued: RAWD } \\
\hline TPA Milestol & & & & \\
\hline Milestone & Description & $\begin{array}{l}\text { Due } \\
\text { Date }\end{array}$ & $\begin{array}{l}\text { (F)/(A) } \\
\text { Date }\end{array}$ & \\
\hline$M-15-23 B$ & $\begin{array}{l}\text { Submit 300-FF-2 Focus Feasibility Study (FFS) and } \\
\text { Proposed Plan (PP) for Regulator Review }\end{array}$ & $11 / 30 / 99$ & $11 / 22 / 99(A)$ & \\
\hline$M-15-00 B$ & $\begin{array}{l}\text { Complete all } 300 \text { Area Operable Unit Pre-ROO Site } \\
\text { Investigations under Approved Work Plan Schedules }\end{array}$ & $12 / 31 / 99$ & $11 / 22 / 99(A)$ & \\
\hline$M-16-92 B$ & $\begin{array}{l}\text { ERDF Cells } 3 \text { \& } 4 \text { Ready to Accept Remediation } \\
\text { Waste }\end{array}$ & $12 / 31 / 99$ & $12 / 09 / 99(A)$ & \\
\hline$M-15-00 A$ & $\begin{array}{l}\text { Complete all Remaining } 100 \text { Area Operable Unit Pre- } \\
\text { ROD Site Investigations under Approved Work Plan } \\
\text { Schedules (100-KR-2, 100-KR-3, 100-FR-2, } \\
100-I U-2 \text {, and 100-IU-6) }\end{array}$ & $12 / 31 / 99$ & $12 / 21 / 99(A)$ & Green \\
\hline$M-16-08 B$ & $\begin{array}{l}\text { Complete Remediation and Backfill of } 22 \text { Waste } \\
\text { Sites in the 100-BC-1 and 100-BC-2 Operable Units } \\
\text { as Defined in the Remedial Design Report/Remedial } \\
\text { Action Work Plan for the } 100 \text { Area }\end{array}$ & $3 / 31 / 00$ & $3 / 24 / 00(F)$ & \\
\hline$M-16-13 A$ & Initiate Remedial Action for 100-FR-1 Operable Unit & $9 / 29 / 00$ & $6 / 01 / 00(F)$ & \\
\hline$M-16-03 E$ & $\begin{array}{l}\text { Complete Remediation of the Waste Sites in the } \\
300-F F-1 \text { Operable Unit (excluding the 618-A Burial } \\
\text { Ground), to Include Excavation, Verification, and } \\
\text { Backfilling }\end{array}$ & $12 / 31 / 00$ & $12 / 31 / 00(F)$ & \\
\hline$* * M-16-26 B$ & $\begin{array}{l}\text { Complete Remediation, Backfill and Revegetation of } \\
51 \text { Liquid Waste Sites and Process Effluent Pipelines } \\
\text { in the 100-BC-1, 100-BC-2, 100-DR-1, 100-DR-2, } \\
\text { and 100-HR-1 Operable Units as defined in the } \\
\text { Remedial Design Report/Remedial Action Work Plan } \\
\text { for the 100 Area (DOE/RL-96-17) }\end{array}$ & $2 / 28 / 01$ & $2 / 28 / 03(F)$ & Ye \\
\hline
\end{tabular}

- DNFSB Commitment:

None identified at this time.

\section{PERFORMANCE OBJECTIVES: $R A W D$}

\begin{tabular}{|l|l|l|}
\hline \multicolumn{1}{|c|}{ Outcome } & \multicolumn{1}{|c|}{ Performance Indicator } & \multicolumn{1}{|c|}{ Status } \\
\hline $\begin{array}{l}\text { Restore the River Corridor } \\
\text { for Multiple Uses }\end{array}$ & $\begin{array}{l}100 / 300 \text { Area waste excavation, } \\
\text { disposal and backfill/regrade. }\end{array}$ & $\begin{array}{l}\text { Baseline work is projected to be } \\
\text { completed per PI requirements. }\end{array}$ \\
\hline
\end{tabular}

Green 


\section{ENVIRONMENTAL MANAGEMENT PERFORMANCE REPORT ENVIRONMENTAL RESTORATION \\ MAY 2000}

PEFORMANCE MEASURES: RAWD - (River and Plateau)

\begin{tabular}{|c|c|c|c|c|c|c|}
\hline & $\begin{array}{l}\text { DWP } \\
\text { FY00 }\end{array}$ & $\begin{array}{l}\text { FYo0 Mgmt } \\
\text { Commitments }\end{array}$ & $\begin{array}{c}\text { Current Baseline } \\
\text { (Incl. Baseline } \\
\text { Changes) }\end{array}$ & $\begin{array}{l}\text { Forecast } \\
\text { For } \\
\text { FYoO }\end{array}$ & $\begin{array}{l}\text { Completed } \\
\text { YTD }\end{array}$ & \\
\hline Waste Sites & 24 & 41 & 40 & 40 & 10 & \\
\hline $\begin{array}{l}100 \text { Area Burial } \\
\text { Ground } \\
\text { Asssessments }\end{array}$ & 0 & 47 & 47 & 47 & $47^{d}$ & \\
\hline $\begin{array}{l}300-F F-2 \\
\text { Ascessments }\end{array}$ & 119 & 118 & 119 & 119 & $119^{a, b}$ & Green \\
\hline Other Assessments & 2 & 2 & 2 & 2 & $0^{0}$ & \\
\hline Tons & $389 K$ & $N a$ & $624 K$ & $624 K$ & $340 K$ & \\
\hline
\end{tabular}

\section{STRETCH AND SUPERSTRETCH GOALS: RAWD}

\section{FY00 "Stretch" Goals \\ Scope \\ Approved \\ Dollars (K) $\quad$ BCPs (K)}

Perform Excavation in Unfunded Sites in 100 B/C MR-1, FR-1, 100, and 300 Area and Plumes:

(1) Extended Plumes at 316-1 S. Pond (BCP-20043)

(2) Additional P/umes at 100-DR (BCP-20050)

(3) Additional P/umes at 100-HR (BCP-20119)

(4) Additional P/umes at 100-HR (BCP-20130)

(5) Additional Plumes at 300-FF (BCP-20113)

(6) Additional P/umes at 100-DR (BCP-20116)

(7) Defer Bachfill at 100-DR (BCP-20166)

$\$ 1,202.8 K$ $\$ 905.8 K$ $\$ 240.3 K$ $\$ 426.7 K$ $\$ 669.4 K$ $\$ 175.2 K$ (\$93.2K) $\$ 3,445.0 K$ 


\section{ENVIRONMENTAL MANAGEMENT PERFORMANCE REPORT ENVIRONMENTAL RESTORATION \\ MAY 2000}

STRETCH AND SUPERSTRETCH GOALS continued: RAWD

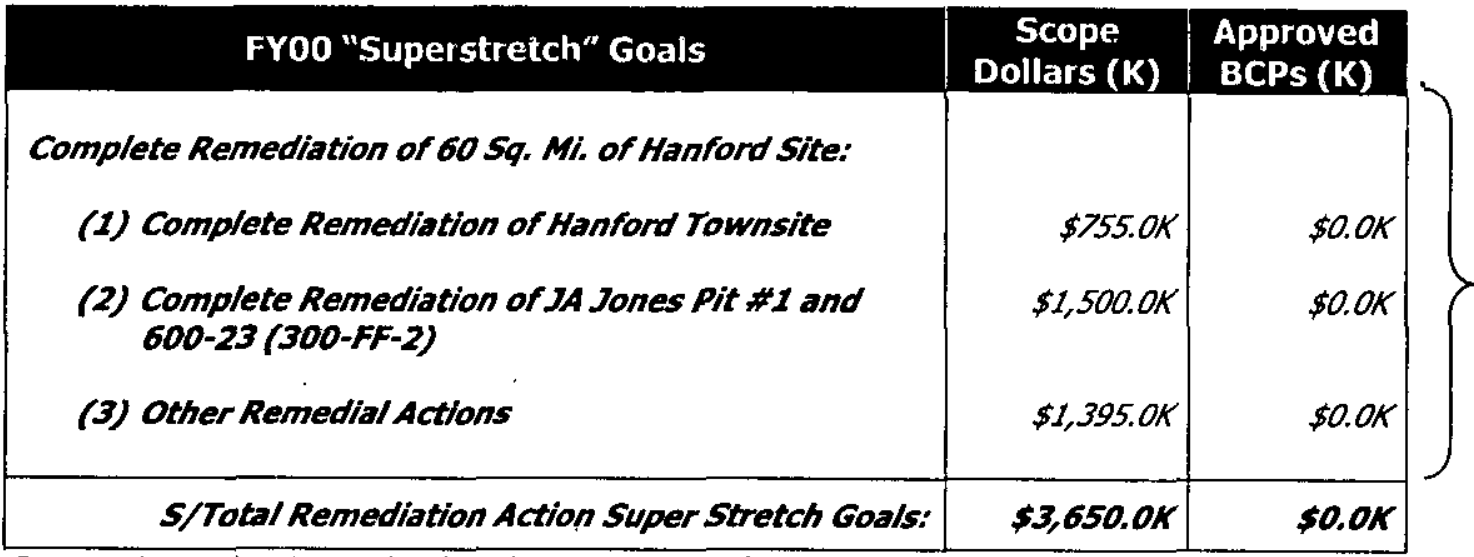

Status: Plan and estimate developed, current work efforts focusing on stretch activities at this time.

\section{PROJECT STATUS (COST/SCHEDULE/MAJOR BASELINE CHANGE: RAWD}

\section{- Schedule:}

\begin{tabular}{|c|c|c|c|}
\hline \multirow{2}{*}{ Remedial Action \& Waste Disposal Project } & BCWS & BCWP & Variance \\
\hline & $\$ \mathbf{K}$ & $\$ \mathbf{K}$ & $\$ \mathbf{K}$ \\
\hline ERO1 1OO Area Remedim/ACOOHS & 14,338 & 14,379 & 41 \\
\hline ERO3 300 Area Remedial Actions & 4,118 & 4,353 & 235 \\
\hline EROA ER Waste Dispasal & 10,622 & 10,609 & -13 \\
\hline 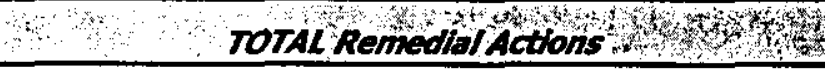 & 29,078 & 29,341 & 263 \\
\hline
\end{tabular}

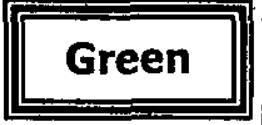

PBS-ER-01 - 100 Area Remedial Action

Schedule Variance $=[+\$ 41 K ;+0.3 \%][$ Last Month: $(+\$ 60 K) ;(+0.5 \%)]$

Cause: Ahead of schedule on NR-1 crib remediation site prep; offset by delays at FR from plume growth and at HR due to arsenic contamination in the soil.

Resolution: FR plumes will require a Baseline Change Proposal; ER is working with the regulators to resolve arsenic cleanup standard.

\section{PBS-ER-03 - 300 Area RemedialAction}

Schedule Variance $=[+\$ 235 K) ;(+5.7 \%)][$ Last Month: $(-\$ 217 K) ;(-6.4 \%)]$

Cause: Excavation of landfill $1 B$ is ahead of schedule; expect early completion.

Resolution: None required; will complete ahead of schedule based on tonnage quantities.

PBS-ER-04 - Envirommental Restoration Waste Disposal

Schedule Variance $=[(-\$ 13 K) ;(-0.1 \%)][$ Last Month: $(-\$ 48 K) ;(-0.5 \%)]$

Cause: On schedule.

Resolution: None required. 


\section{ENVIRONMENTAL MANAGEMENT PERFORMANCE REPORT ENVIRONMENTAL RESTORATION \\ MAY 2000}

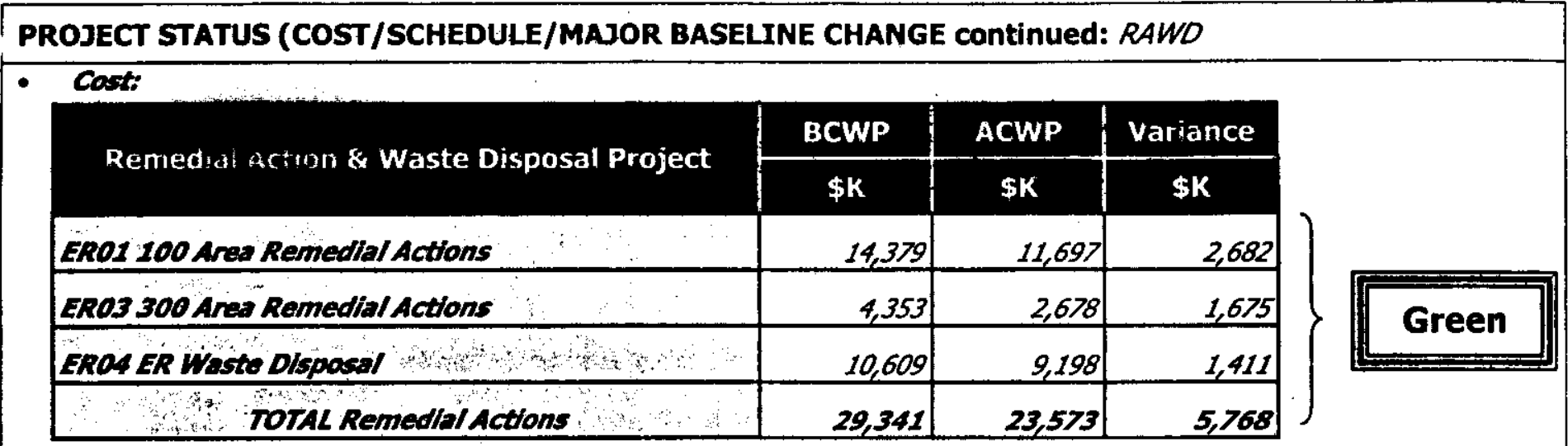

PBS-ER-01 - 100 Area Remedial Action

Cost Variance $=[+\$ 2682 K ;+18.7 \%]$ [Last Month: $+\$ 2165 K ;+18.2 \%]$

Cause: DR contract award on small sites excavation was less than budgeted; FR savings in site prep and staff reductions; labor savings on B/C backfill activities.

Resolution: Savings will be used to perform other remediation work.

PES-ER-03 - 300 Area Remedial ACtion

Cost Vaniance $=[+\$ 1675 K ;+38.5 \%$ ] [Last Month: $+\$ 1019 K ;+32.2 \%$ ]

Cause: Management and administrative cost efficiencies at Landfills $1 \mathrm{~A} 1 \mathrm{1B}$, and $\$ 500 \mathrm{~K}$ under accrual in South Process Pond remediation.

Resolution: Savings will be used to perform other remediation work.

PBS-ER-04 - Environmental Restoration Waste Disposal

Cost Variance $=[+\$ 1411 K ;+13.3 \%$ ] [Last Month: $+\$ 1275 K ;+14.6 \%]$.

Cause: Reflects FY 1999 over accrual.

Resolution: Savings will be used to perform other remediation work.

\section{REGULATORY ISSUES: RAWD}

Tri-Party Agreement Milestone: (1) Milestone M-16-26B due February 28, 2001. Complete remediation and backfill of 51 liquid waste sites at $B / C, D R$ and HR is impacted by $B / C$ pipelines.

Status: A resolution with the regulators is required to be negotiated. The path forward is to submit a Tri-Party Agreement Change Package to the regulators for review and evaluate out year funding and prionities.

Arsenic Strategy for 100 Area Remediation: Variance sampling was completed in November 1999 for 1607-H2 and 1607-H4 septic systems. Arsenic data in the overburden and shallow zone soils exceeded Remedial Action Gaals (RAGs), (Hanford Background). The average ranged from $8-11 \mathrm{mg} / \mathrm{kg}$, maximum $30 \mathrm{mg} / \mathrm{kg}$; Hanford Background $6.5 \mathrm{mg} / \mathrm{kg}$. Records indicate that no arsenic was used in processes at the $100 \mathrm{H}$ Area Historical research indicates lead arsenate was used as a pesticide in pre-Hanford agricultural lands (predominantly orchards). Application rates were as high as $250 \mathrm{lb}$. per acres per year. Lead arsenate pesticide was used from the early 1900's to 1942. By 1942, Hanford agricultural land is estimated at 13,000 acres dry land farming and 18,000 acres in irrigation districts. 


\section{ENVIRONMENTAL MANAGEMENT PERFORMANCE REPORT ENVIRONMENTAL RESTORATION \\ MAY 2000}

REGULATORY ISSUES: RAWD

Status: The plan to address the elevated arsenic levels encountered during the confirmation sampling activities was pulled back by the Washington State Department of Ecology during the March Unit Managers Meeting. This delay may cause the recently negotiated completion date for Tri-Party Agreement Milestone M-16-26C, Complete Remediation and Backfill of 10 Liquid Waste Sites in the 100 H Operable Unit by May 31, 2001 to slip. The initial indication is that Ecology will want to obtain additional arsenic samples throughout the 100 Areas of the Hanford site prior to resolving the issue. It may cause up-to a three-month delay in confirmation sampling and verification package activities for the 100 H Operable Unit remediation activities.

Discussion of the issue with Washington State Department of Ecology and the U.S. Environmental Protection Agency is planned during the May 2000 brown bag meeting. If no progress is made during the brown bag meeting, a letter will be issued requesting resolution of the Pre-Hanford Arsenic Issue from the Washington State Department of Ecology and the U.S. Environmental Protection Agency.

EXTERNAL ISSUES (i.e. HAB, Congress, etc.): RAWD

None identified at this time.

DOE-RL \& HQ ISSUES/REQUESTS (not covered elsewhere): RAWD

None identified at this time.

INTEGRATION ACTIVITIES: RAWD

None identified at this time. 


\section{ENVIRONMENTAL MANAGEMENT PERFORMANCE REPORT}

ENVIRONMENTAL RESTORATION

MAY 2000

\section{Decommissioning Projects (D\&D)}




\section{ENVIRONMENTAL MANAGEMENT PERFORMANCE REPORT ENVIRONMENTAL. RESTORATION \\ MAY 2000}

\section{SECTION B - RESTORING THE RIVER CORRIDOR}

\section{Financial / Performance Measures data as of month-end March.}

All other data as of April 20, unless otherwise noted.

Decommissioning Projects (D\&D):

ACCOMPLISHMENTS: D\&D

233-S: Completed viewing room airline piping removal.

Completed $L-18$ cubicle rad survey.

Removed three $3^{d}$ floor process hood front face PMMA panels (non-TRU by NDA).

Removed four large supply duct sections from the 233-S building roof.

Initiated cutting process hood stainwell supply duct.

224B: Completed initial radiological survey and walkdown at 2248 offices and storage areas.

Drafted memorandum of agreement to allow access for engineering planning and DQO development.

ISS: The 105-D \& H Reactor Engineering Evaluation/Cost Analysis (EE/CA) and the 105-D Auditable Safety Analysis (ASA) drafts were submitted to DOE-RL in March. (Completes PI \#3A \& partial completion of 4A.) $R L$ evaluation is in progress.

Began demolition of the North Reactor Slab5 and tunnel at 105-DR Reactor in mid-March.

Completed demolition preparation activities at 105-DR Gas Recirculation tunnel and South Sample Rooms.

F Reactor SSE pourback subcontractor began mobilization and preparation on work for the pourbacks in the valve pit at $F$ Reactor.

105-B Safe Storage: The draft B Reactor Safe Storage Phase II Feasibility Study is 30\% complete. The project team reviewed the document and provided comments to the subcontractor.

Digital recording of artifact collection being conducted by Columbia River Exhibition of History, Science, and Technology (CREHST).

U.S. Corps of Engineers evaluation of B Reactor for suitability as a long-term repository for artifacts and records.

\section{SAFETY/ISMS/CONDUCT OF OPS: $D \& D$}

See Cross-Cutting Package.

\section{BREAKTHROUGHS/OPPORTUNITIES FOR IMPROVEMENT: D\&D}

None identified at this time.

\section{LONG-TERM (6 MONTHS PLUS) IMPORTANT ITEMS: D\&D}

None identified at this time.

\section{MAJOR COMMITMENTS (FISCAL YEAR PLUS 6 MONTHS): D\&D}

- DOE Secretarial:

None identified at this time. 


\section{ENVIRONMENTAL MANAGEMENT PERFORMANCE REPORT ENVIRONMENTAL RESTORATION \\ MAY 2000}

\begin{tabular}{|c|c|c|c|c|c|c|c|}
\hline MAJOR COMM & IENTS (FIS & AL YEAR I & 6 MONTH & con & ed: $D \& D$ & & \\
\hline $\begin{array}{l}\text { DOE EM Pef } \\
\text { 224-B: Comp } \\
\text { Complete draf }\end{array}$ & $\begin{array}{l}\text { ormance Agre } \\
\text { te draft EECA a } \\
\text { SAP and submi }\end{array}$ & $\begin{array}{l}\text { arment: } \\
\text { nd submit to reg } \\
\text { to regulators - }\end{array}$ & $\begin{array}{l}\text { tors - July } 200 \\
\text { otember } 2000 .\end{array}$ & & & - & Yellay \\
\hline - TPA MIlesto & 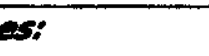 & & & & & & \\
\hline Milestone & & Descript & & & Due Date & $\begin{array}{c}\text { (F)/(A) } \\
\text { Date }\end{array}$ & \\
\hline M-93-05 & $\begin{array}{l}\text { Issue B React } \\
\text { Design Report }\end{array}$ & $\begin{array}{l}\text { of Phase II Feast } \\
\text { for Public Comm }\end{array}$ & ty Study Engine & ering & $6 / 30 / 00$ & $6 / 30 / 00$ (F) & Green \\
\hline $\begin{array}{l}\text { DNFSB Com } \\
\text { None identified }\end{array}$ & $\begin{array}{l}\text { aitment: } \\
\text { at this time. }\end{array}$ & & & & & & \\
\hline PERFORMANC & OBJECTIVE & $D \& D$ & & & & & . \\
\hline Outc & me & Peiforman & Indicator & & Status & & \\
\hline $\begin{array}{l}\text { Restore the } \\
\text { for Multiple }\end{array}$ & ver Corridor & $\begin{array}{l}\text { Reactor ISS an } \\
\text { faclities for de }\end{array}$ & $\begin{array}{l}\text { reparation of } \\
\text { nmissioning. }\end{array}$ & $\begin{array}{l}\text { Basel } \\
\text { projec } \\
\text { requir }\end{array}$ & $\begin{array}{l}\text { te reactor ISS } \\
\text { ted to be comp } \\
\text { ements. }\end{array}$ & $\begin{array}{l}\text { onk is } \\
\text { eted per PI }\end{array}$ & \\
\hline & & $\begin{array}{l}\text { Maintain facilit } \\
(233-5) \text {. }\end{array}$ & until D\&D & $\begin{array}{l}F Y 20 \\
B C P-2 \\
2000 . \\
\text { drafte }\end{array}$ & $\begin{array}{l}10 \text { work reseque } \\
0141 \text {, approved } \\
\text { New performal } \\
\text { d and submitted }\end{array}$ & $\begin{array}{l}\text { nced via } \\
\text { March 14, } \\
\text { ice indicators } \\
\text { for approval. }\end{array}$ & Green \\
\hline $\begin{array}{l}\text { Transibion Ce } \\
\text { to Support Lo } \\
\text { Waste Manas }\end{array}$ & $\begin{array}{l}\text { tral Plateau } \\
\text { g-Term } \\
\text { ment }\end{array}$ & $\begin{array}{l}\text { Maintain facilith } \\
(224-B) \text {. }\end{array}$ & until D\&D & $\begin{array}{l}\text { 224B } \\
\text { inope } \\
\text { and } \\
\text { EE/C } \\
\text { appro } \\
\text { suppo } \\
\text { ventil } \\
\text { comp } \\
\text { fiscal } \\
\text { estab } \\
\text { perfo } \\
\text { revisi }\end{array}$ & $\begin{array}{l}\text { baseline work in } \\
\text { able B-Plant ex } \\
\text { gulator refusal } \\
\text { Project has d } \\
\text { ch to conduct } \\
\text { tof the DQO w } \\
\text { tion. The SAP } \\
\text { eted before the } \\
\text { ear if regulator } \\
\text { shed. If not, th } \\
\text { mance measure } \\
n \text { n. }\end{array}$ & $\begin{array}{l}\text { pacted by } \\
\text { haust system } \\
\text { to review } \\
\text { langed the } \\
\text { valkdowns in } \\
\text { ithout } \\
\text { can be } \\
\text { end of the } \\
\text { support is re- } \\
\text { is } \\
\text { will require }\end{array}$ & 110 \\
\hline PERFORMAN & URE & & & & & & \\
\hline & & $\begin{array}{l}\text { DWP } \\
\text { FYO0 }\end{array}$ & $\begin{array}{r}\text { Current Bas } \\
\text { (Incl. Base } \\
\text { Change }\end{array}$ & $\begin{array}{l}\text { seline } \\
\text { eline } \\
\text { s) }\end{array}$ & $\begin{array}{l}\text { Forecast } \\
\text { For FyO0 }\end{array}$ & $\begin{array}{c}\text { Completed } \\
\text { YTD }\end{array}$ & \\
\hline Facilities & & 0 & $4^{c}$ & & $4^{c}$ & $3^{d}$ & Green \\
\hline $\begin{array}{l}{ }^{6} 116-0,116- \\
116-0,116-\end{array}$ & $19-D R$ and & Fingl Remons & 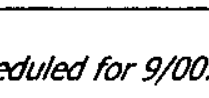 & & & & \\
\hline
\end{tabular}




\section{ENVIRONMENTAL MANAGEMENT PERFORMANCE REPORT ENVIRONMENTAL RESTORATION \\ MAY 2000}

STRETCH AND SUPERSTRETCH GOALS: D\&D

\begin{tabular}{|l|r|r|}
\hline \multicolumn{1}{|c|}{ FY00 "Superstretch" Goals } & \multicolumn{1}{|c|}{$\begin{array}{c}\text { Scope } \\
\text { Dollars (K) }\end{array}$} & $\begin{array}{c}\text { Approved } \\
\text { BCPs (K) }\end{array}$ \\
\hline $\begin{array}{l}\text { *Continue F Reactor Interim Safe Storage (ISS) } \\
\text { (BCP-20151) }\end{array}$ & $\$ 2,000.0 \mathrm{~K}$ & $\$ 1490.8 \mathrm{~K}$ \\
\hline Public Access to Hanford Townsite and B Reactor & $\$ 750.0 \mathrm{~K}$ & $\$ 0.0 \mathrm{~K}$ \\
\hline S/Total D\&D Super Stretch Goals: & $\$ 2750.0 \mathrm{~K}$ & $\$ 1490.8 \mathrm{~K}$ \\
\hline
\end{tabular}

*Status: Requires funding support outside of ER to execute Superstretch.

\section{PROJECT STATUS (COST/SCHEDULE/MAJOR BASELINE CHANGE): D\&D}

\section{- Schedules}

\begin{tabular}{|c|c|c|c|}
\hline \multirow{2}{*}{ Decommissioning Projects } & BCWS & BCWP & Variance \\
\hline & $\$ K$ & $\mathbf{\$ K}$ & $\$ K$ \\
\hline ERO6 Decontamination a Decommistorioning & 7,911 & 7,252 & -659 \\
\hline ototal D\&D & $\geqslant 911$ & 7,252 & -659 \\
\hline
\end{tabular}

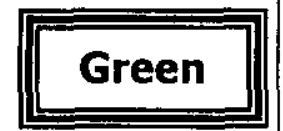

PBS-ER-06 - Decontamination and Decommissioning

Schedule Variance $=[(-\$ 659 K) ;(-8.3 \%)]$ [Last Month: $(-\$ 528 K) ;(-8.2 \%)]$

Cause: 233-5 decommissioning delay in removal of roof duct and decon due to replacement of deteriorated glove bag; late receipt of waste containers and CAM equipment at 233-S.

Resolution: Duct removal started in late February and completed in mid-March - will correct variance; procurement will increase in next few months and place purchases back on schedule.

Cause: $224 B$ entry was restricted due to inoperable B-Plant exhaust system.

Resolution: Initiated planning for walkdowns without facility ventilation.

- Cost:

\begin{tabular}{|c|c|c|c|c|}
\hline \multirow{2}{*}{ Decommissioning Projects } & BCWP & ACWP & Variance & \\
\hline & $\$ \mathbf{K}$ & $\$ \mathbf{K}$ & $\$ \mathbf{K}$ & \\
\hline ERO6 Decontamination a Decommissioning & 2,252 & 6,903 & 349 & $\Gamma_{n}$ \\
\hline TOTAL D\&D & $\geqslant 252$ & 6,903 & 349 & en \\
\hline
\end{tabular}

PBS-ER-06 - Decontamination and Decommissioning

Cost Variance $=[+\$ 349 K ;+4.8 \%]$ [Last Month: $+\$ 272 K ;+4.6 \%]$

Cause: Sample analysis cost is significantly lower than expected.

Resolution: Savings will be used to perform other remediation work.

Cause: 233-5 - Additional cost to correct air flow and installing electrical upgrades in the viewing room; unexpected difficulties resulted in extra cost to remove glovebag from the Loadout Hood area.

Resolution: Cost overruns are being trended. Engineering controls have been implemented to resume characterization activities. 


\section{ENVIRONMENTAL MANAGEMENT PERFORMANCE REPORT ENVIRONMENTAL RESTORATION \\ MAY 2000}

\section{REGULATORY ISSUES: D\&D}

D\&H Reactor Impacts of TPA milestones: The acceleration of the Reactor ISS has gotten out of sync with the current $M-93$ milestones, especially the competitive procurement and renegotiating milestones for $D R, D$, and $H$ at the same level of detail as $F$ and $C$ reactors.

Status: The new Ecology lead for D\&O was briefed on that status of D\&D by the DOE and BHI PMS. The issues that have been raised by EPA concerning the TPA milestones was discussed and Ecology agreed to contact EPA. The EE/CA for 105-D \& H was sent to Ecology for review to keep the process moving until the issues can be resolved.

105-B Reactor Safe Storage: Discussion with the EPA on the Tri-Party Agreement Milestone M-93-05, "Issue B Reactor Phase II Feasibility Study Engineering Design Report for Public Comment" (6/30/00), indicate that the document would meet the milestone requirements but would not be issued for public comment. The EPA has requested that the feasibility study be expanded to include all building hazards (induding expanded tour route) and an EE/CA be prepared and submitted for public comment. Currently, the project does not have a dear path forward relative to hazard identification and resolution. Funding has not been authorized for hazard reduction.

Status: Work with appropriate RL personnel to determine a path forward.

EXTERNAL ISSUES (i.e. HAB, Congress, etc.): D\&D

None identified at this time.

DOE-RL \& HQ ISSUES/REQUESTS (not covered elsewhere): D\&D

2248: EPA has declined to participate in FY 2000 assessment activities because they do not support FY 2001-2003 DWP funding that would lead to near term 224B decommissioning.

Status: LaCk of EPA comment on the EE/CA will prevent completion. Lack of EPA participation in walkdowns of the facility and the DQO process will prevent development of the Sample and Analysis Plan.

INTEGRATION ACTIVITIES: D\&D

None identified at this time. 
ENVIRONMENTAL MANAGEMENT PERFORMANCE REPORT

ENVIRONMENTAL RESTORATION

MAY 2000

\section{Program Management and Support (PM\&S)}




\section{ENVIRONMENTAL MANAGEMENT PERFORMANCE REPORT ENVIRONMENTAL RESTORATION \\ MAY 2000}

\section{SFCTION B - RESTORING THE RIVER CORRIDOR}

inancial / Performance measures data as of month-end mate

All other data as of April 20, unless atherwise noted.

\section{Program Management \& Support (PM\&S):}

ACCOMPLISHMENTS: PM\&S

Compliance Quality Safety. \& Health

Safety \& Health: The FY $20002^{\text {nd }}$ Quarter Security Self-Assessment Report was issued. This assessment focused on the ERC physical security and badging programs. Two areas of improvement were noted. These are being addressed by BHI Security and the functional organizations.

The new SH-O1, ERC Safety and Health Program manual was issued on March 2.

Activities related to implementation of the revised 10CFR835 activities included:

- Received comments from the projects, the functions, and selected craft workers (RCTs) on the draft Radiological Program Protection Manual (RPPM).

- Developed the following procedures for new Radiological Control manual: Radiation Safety Training, \& Radiological Training for Line Management

- Completed Technical Review of RadWorker training module for plutonium/uranium hazards

Compliance and Quallty Programs/Price Anderson Amendment Act (PAAA): The annual 200 West Area inspection was conducted by site contractors and the Washington State Department of Ecology on March 21. The inspection is a requirement of the sitewide Resource Conservation and Recovery Act (RCRA) permit. No concerns or violations were noted as a resutt of the inspection.

An independent assessment of the corrective action plan submitted to the Environmental Protection Agency (EPA) and Ecology in response to the Notice of Violations (NOVs) concerning management of IOW (tri-butyl phosphate) is ongoing. BHI management has directed Compliance and Quality Programs (CQP) to conduct an independent assessment to verify that commitments made in the response letter have been addressed and implemented, and is effective. Fieldwork will be completed by the end of March, with a proposed final report issued on April 10.

External Affairs: Provided support to DOE's FY 2002 Budget Workshop held on March 15 in Richland. Finalized and forwarded to DOE's Public Involvement Manager the questions and comments from the ER and Waste Management breakout sessions at the Workshop, which will be incorporated into all the comments received at the various meetings for development of a response to comment.

Project Procurement and Property Management: Procurement/Property management personnel attended an overview of a new property system put on by PNNL. Data fields are currently being mapped into this system, which will be on line in June, when all of the other Hanford site contractors complete their system input. Per DOE direction, BHI will wait until FHI completes their package and purchase a single site license thus saving about \$40K over purchasing three licenses. Additional Business Process Improvement meetings were conducted March 28 through 30.

Design Engineering: Initiated activities to coordinate the use of System Leve/ Automation Tools for Engineers (SLATE) with the PHMC. The PHMC is following the BHI lead of implementing SLATE for requirements management. BHI is working with the PHMC to standardize database schema and share specialty processes that enhance our ability to share information.

Technology Application: Submitted F Reactor Fuel Storage Basin Cleanout proposal in response to the Accelerated Site Technology Deployment (ASTD) Program Fy 2000 call for proposals.

Envirommental Technologies: The Environmental Radiological Measurements Plan was issued. The plan describes the process and requirements for planning, performing, and evaluating environmental radiological measurements used for restoration and remediation decisions.

Completed the Decisional Draft "Guidance for Radiological Release of DOE Nonreal Property at Hanford" (BHI-01338). The draft defines the process that will be used for the release of nonreal property (e.g., tools, equipment, steel, concrete rubble) from radiological controls at the Hanford Site. 


\section{ENVIRONMENTAL MANAGEMENT PERFORMANCE REPORT ENVIRONMENTAL RESTORATION \\ MAY 2000}

ACCOMPLISHMENTS: PM\&S

Completed four targets for the Waste Minimization performance incentive: (1) re-deployment of concrete crusher to Ohio, (2) recycled un-needed absorbents to another ERC project, (3) recycled flat bed trailer and generator, and (4) recycled 1,100 drum overpacks.

Planning \& Controls: Rev. 1 Rates - Received DOE-RL approval of Fiscal Year 2000 Revision 1 Provisional Billing Rates.

DWP Rate Development - Started development of rates for the Fiscal Years 2001 through 2003 Detailed Work Plan.

SAFETY/ISMS/CONDUCT OF OPS: PM\&S

See Cross-Cutting Package.

BREAKTHROUGHS/OPPORTUNITIES FOR IMPROVEMENT: PM\&S

None identified at this time.

LONG-TERM (6 MONTHS PLUS) IMPORTANT ITEMS: PM\&S

Planning \& Controls; Mid-Year Review - May 8-9

Detail work planning process for FY 2001 - FY 2003 - Kick-off meeting - June 1

MAJOR COMMITMENTS (FISCAL YEAR PLUS 6 MONTHS): PM\&S

- DOE Secretarial:

None identified at this time.

- DOE EM Performance Agreement:

None identified at this time.

- TPA Milestones:

None identified at this time.

- DNFSB Commitment:

None identified at this time.

PERFORMANCE OBJECTIVES: PM\&S

None identified at this time.

PERFORMANCE MEASURES: PM\&S

None planned in FY 2000.

STRETCH AND SUPERSTRETCH GOALS: PM\&S

None identified at this time. 


\section{ENVIRONMENTAL MANAGEMENT PERFORMANCE REPORT ENVIRONMENTAL RESTORATION \\ MAY 2000}

\section{PROJECT STATUS (COST/SCHEDULE/MAJOR BASELINE CHANGE): PM\&S}

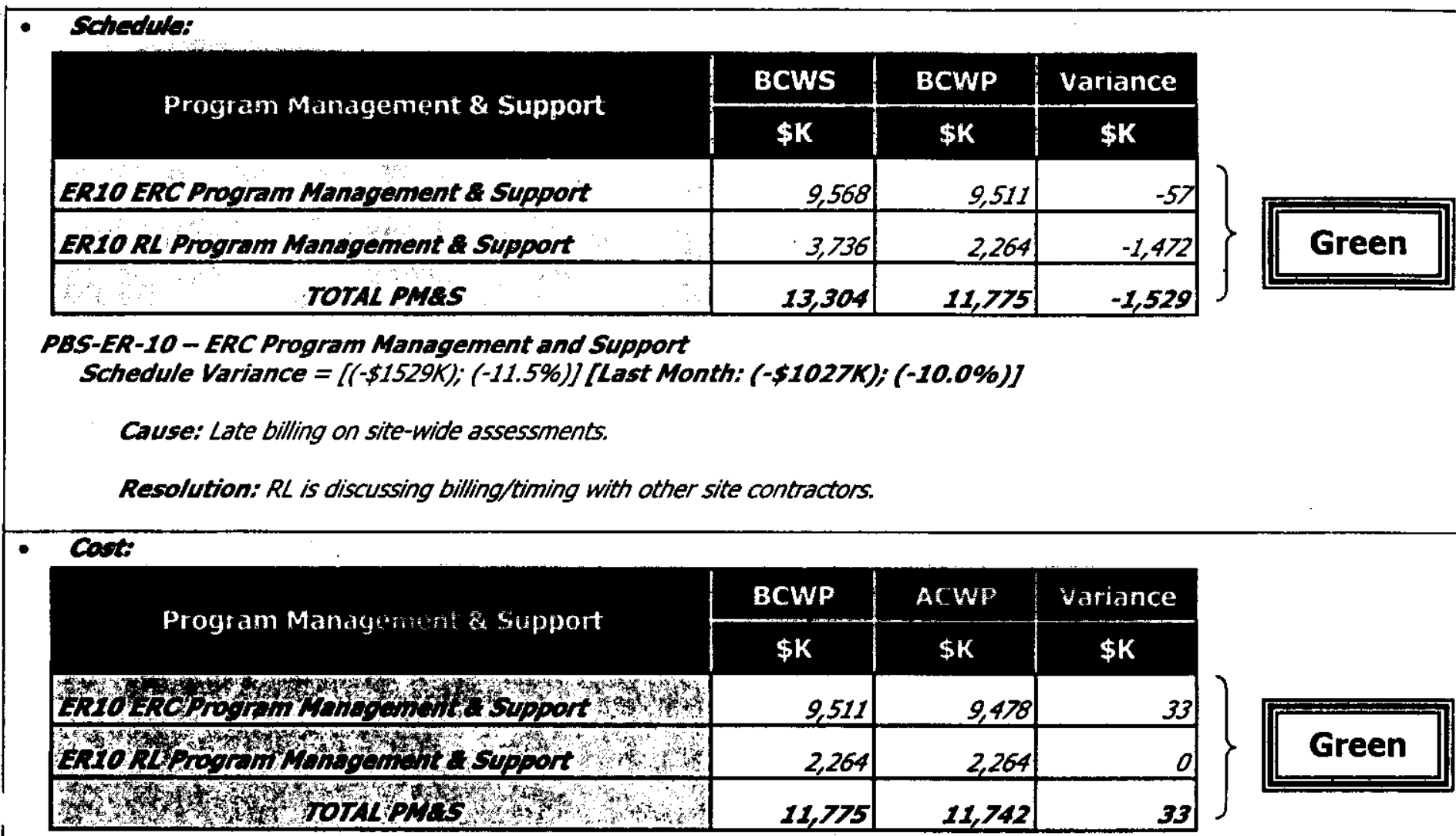

PAS-ER-10 - ERC Program Management and Support

Cost Variance $=[+\$ 33 K ;+0.3 \%]$ [Last Month: $+\$ 44 K,+0.5 \%]$

On Budget.

\section{REGULATORY ISSUES: PM\&S}

None identified at this time.

EXTERNAL ISSUES (i.e. HAB, Congress, etc.): PM\&S

None identified at this time.

DOE-RL \& HQ ISSUES/REQUESTS (not covered elsewhere): PM\&S

None identified at this time.

\section{INTEGRATION ACTIVITIES: PM\&S}

None identified at this time. 


\section{Richland Operations Office \\ Environmental Restoration \\ Environmental Management Performance Report}

\section{Section C - Central Plateau Intollzzicitolz}

May 2000

Transition the Central Plateau

- Groundwater / Vadose Zone Integration Project.

- Survellance / Malntenance \& Transition Projects

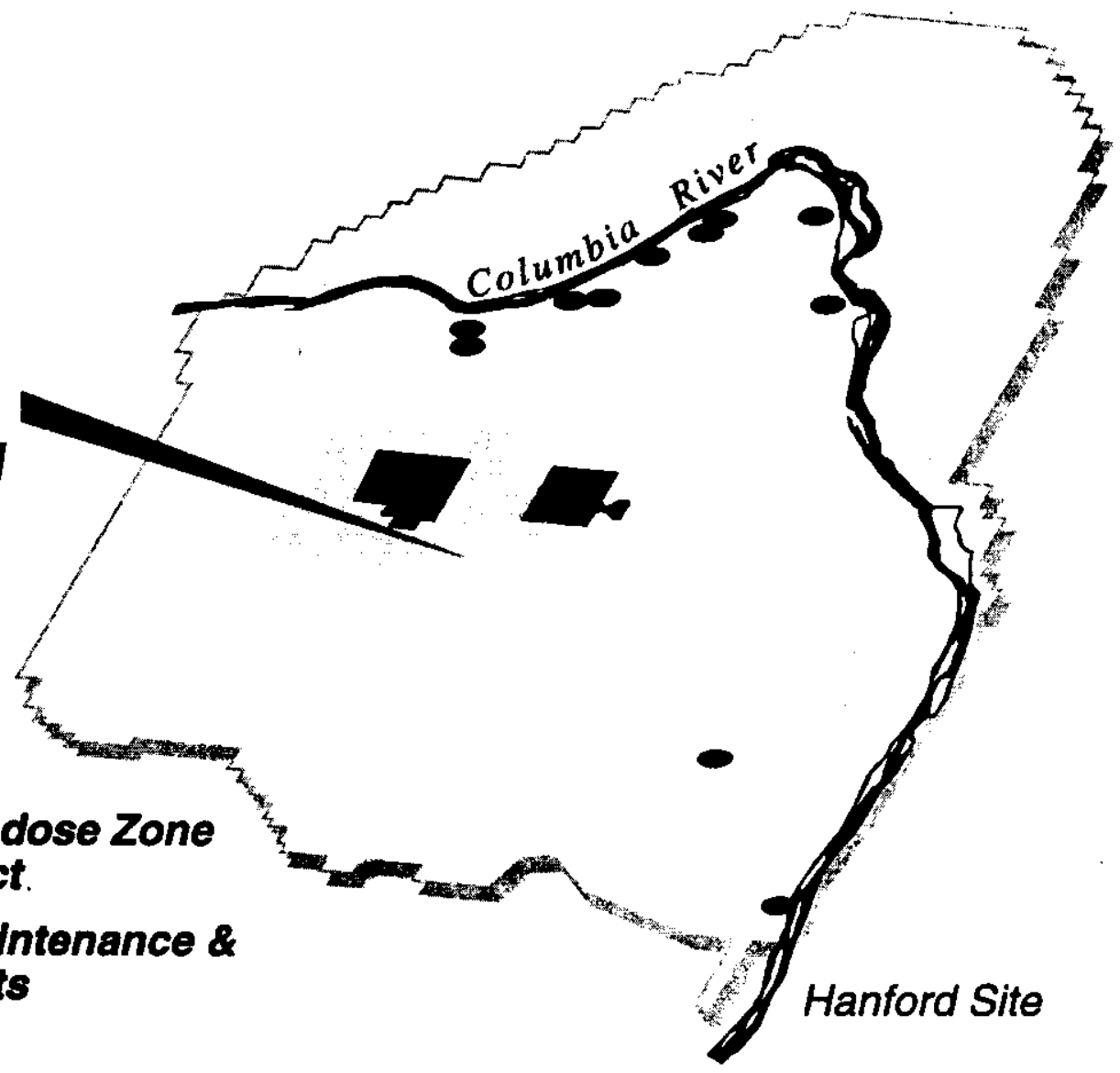

Focused on Progress...

Focused on Outcomes!

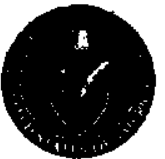

Department of Energy

Richland Operations Office

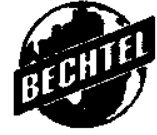

Bechtel Hanford, Inc.

Environmental Restoration Contractor 
ENVIRONMENTAL MANAGEMENT PERFORMANCE REPORT ENVIRONMENTAL RESTORATION CONTRACT MAY 2000 


\section{ENVIRONMENTAL MANAGEMENT PERFORMANCE REPORT ENVIRONMENTAL RESTORATION CONTRACT \\ MAY 2000}

\section{SECTION C - TRANSITIONING THE CENTRAL PLATEAU}

Financial / Performance Measures data as of month-end March.

All other data as of April 20, unless otherwise noted.

Groundwater/Vadose Zone Integration (GW/VZ):

\section{ACCOMPLISHMENTS: $G W / V Z$}

General Project: Conducted contractor Project Retreat with team members to identify integration areas, scope summary, assumptions and key deliverables between four work groups: Modeling and Assessment, Characterization/Monitoring, Remediation, and Data Interpretation/Conceptual Modeling in preparation for the upcoming FY 2001 -FY 2003 DWP process.

200 Area Assessment: Worked with Science and Technology (S\&T) to coordinate 200 Area field characterization work with sampling needs for S\&T actinide mobility investigations.

Long-Term Monitoring: Distributed data reports and developed a process and a map to show recent analysis results posted on the FY 1999 plume map. These address corrective actions resulting from the tritium off normal occurrence report.

Tritium Investigation: Received over $95 \%$ of the data from the Phase I sampling event from the laboratory.

Conducted a Data Quality Objective (DQO) status meeting with members of the technical tearn in support of developing and issuing the DQO Summary Report. This report will be the basis of the scope for Phase II Tritium Investigation.

Completed and provided to DOE-RL a letter to address Ecology's request for re-evaluation of historical Tritium data near the 618-11 Burial Grounds.

Pump and Treat Systems: All groundwater pump and treat systems have operated above planned avallability levels through March.

ISRM Drilling/Injection: Completed FY 2000 ISRM well installations. Sixteen wells have been drilled and completed total depth. Project on schedule.

Science \& Technology: Submitted the S\&T Roadmap for Project review and comment. The revision of the roadmap includes the risk technical element and provides the basis for fy 2001 work scope.

Completed coordination plans between Representative Sites and RPP Vadose Zone on the SX-108 slant bore hold. This work will provide S\&T input to the RPPS-SX Field Investigation Report.

System Assessment Capability: Completed Peer Review of SAC Rev. O Design Document and Detailed Software Design Document.

Characterization of Systems: Received technical staff comments on the Conceptual Model Approach paper and commenced document revision.

Public Involvement: Met with DOE-RL and DOE-HQ to develop a scope and schedule for the May 2000 Semi-Annual Report to Congress.

Drafted a response letter for DOE-RL concerning Governor Locke's inquiring about the Tritium Investigation.

\section{Green}

SAFETY/ISMS/CONDUCT OF OPS: GWNZ

See Cross-Cutting Package.

BREAKTHROUGHS/OPPORTUNITIES FOR IMPROVEMENT: GW/VZ

None identified at this time. 


\section{ENVIRONMENTAL MANAGEMENT PERFORMANCE REPORT ENVIRONMENTAL RESTORATION CONTRACT \\ MAY 2000}

LONG-TERM (6 MONTHS PLUS) IMPORTANT ITEMS continued: $G W / Z Z$

KeY ISRM FY2000 Activities:

FY 2001 Activities: (Planned Activities)

Activities: Drill and install 24 JSRM Barrier Wells. Utilize all wells for ISRM Barrier emplacement. [Approximately 240 meters of additional ISRM Barrier length to be constructed in FY 2001.]

Drill and install 4 ISRM compliance wells.

FY 2002 Activities: (Planned Activities)

Activities: Drill and install 24 ISRM Barrier Wells. Utilize all remaining wells for ISRM Barrier emplacement.

[Approximately 240 meters of additional ISRM Barrier length to be constructed in FY 2002.]

Demobilize evaporation pond (FY 2002 or FY 2003 Activity).

MAJOR COMMITMENTS: GWNZ

- DOE Secretarial:

None identified at this time.

- Fr 2000 Management Commitment Milestones:

Transmit Update of the Vadose Zone Science and Technology Roadmap (PBS VZO1) due April 30.

Status: Draft was provided to DOE on April 14.

Complete Installation of the Wells and Initiate Injection of the Barrier for Phase II of the In Situ REDOX Manipulation Project (PBS ERO8) due September 30.

Status: Forecasted to be complete by September 30. (Well installation completed on April 24.) Complete the Semi-Annual Groundwater/Nadose Zone Report (December 1999 - March 2000) due May 31.

Status: Forecasted to be completed by May 31. 


\section{ENVIRONMENTAL MANAGEMENT PERFORMANCE REPORT ENVIRONMENTAL RESTORATION CONTRACT MAY 2000}

(5) MAJOR COMMITMENTS continued: GW/VZ

\section{- TPA Milestones:}

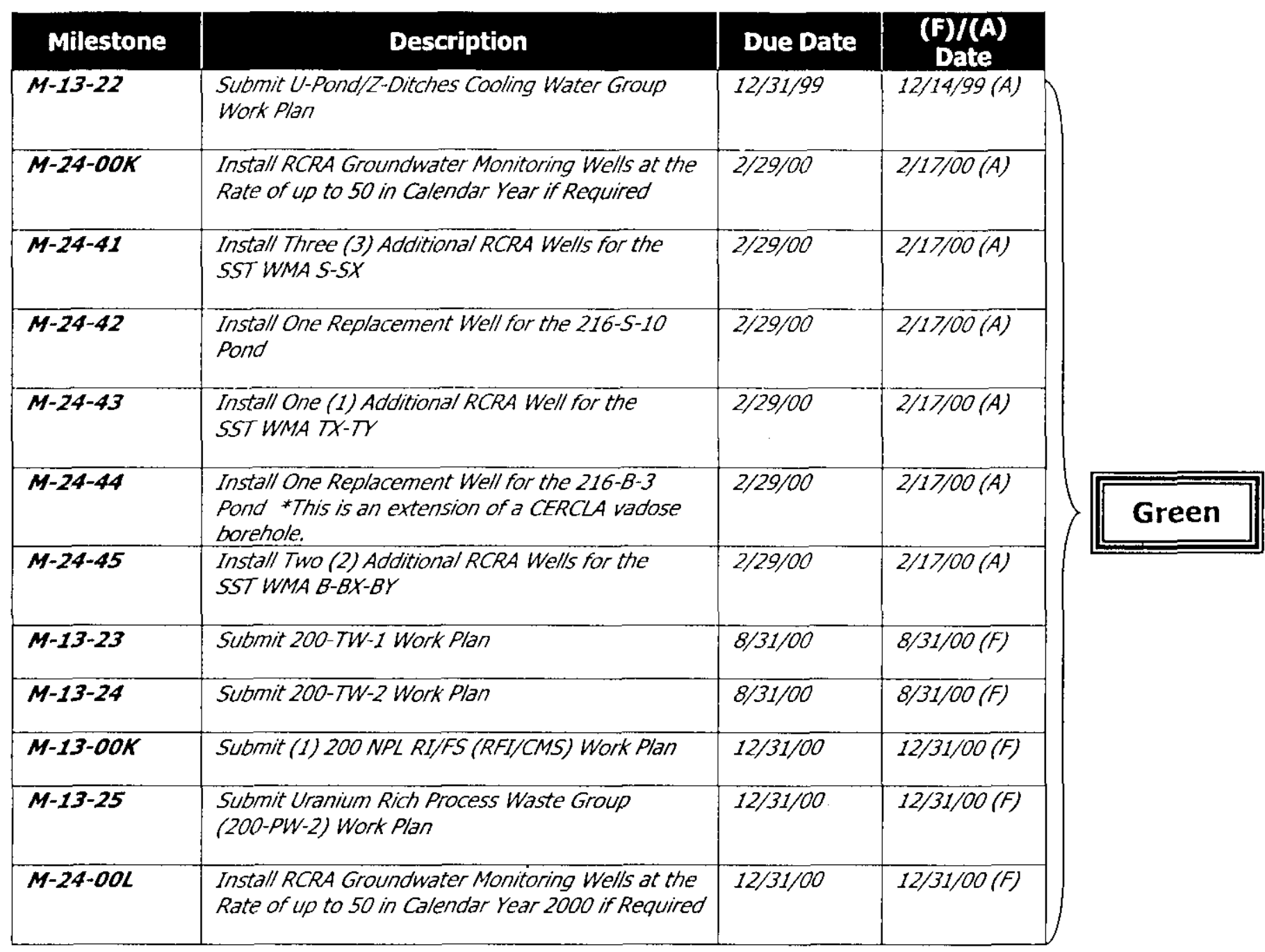

- DNFSB Commitment:

None identified at this time. 


\section{ENVIRONMENTAL MANAGEMENT PERFORMANCE REPORT ENVIRONMENTAL RESTORATION CONTRACT \\ MAY 2000}

PERFORMANCE OBJECTIVES: GW/VZ - (River and Plateau)

\begin{tabular}{|c|c|c|}
\hline Outcome & Performance Indicator & Status \\
\hline $\begin{array}{l}\text { Restore the River Corridor for } \\
\text { Multiple Uses }\end{array}$ & $\begin{array}{l}\text { Manage groundwater plumes per } \\
\text { interim RODs. }\end{array}$ & $\begin{array}{l}\text { Baseline work is projected to be } \\
\text { completed per PI requirements, } \\
\text { BCP-20065 was submitted and } \\
\text { approved to extend the ISRM } \\
\text { drilling schedule as a result of } \\
\text { late signing of the } 100-H R-3 \\
\text { ROD. }\end{array}$ \\
\hline \multirow{3}{*}{$\begin{array}{l}\text { Transition Central Plateau to } \\
\text { Support Long-Term Waste } \\
\text { Management }\end{array}$} & $\begin{array}{l}\text { Complete system assessment } \\
\text { capability. }\end{array}$ & $\begin{array}{l}\text { Baseline work projected to be } \\
\text { completed per PI requirements }\end{array}$ \\
\hline & Soil sites assessments. & $\begin{array}{l}\text { Baseline work projected to be } \\
\text { completed per PI requirements. }\end{array}$ \\
\hline & $\begin{array}{l}\text { Manage groundwater plumes per } \\
\text { interim RODs }\end{array}$ & $\begin{array}{l}\text { All measures projected to meet } \\
\text { PI requirements; all baseline } \\
\text { work projected to be completed } \\
\text { per PI requirements. }\end{array}$ \\
\hline
\end{tabular}

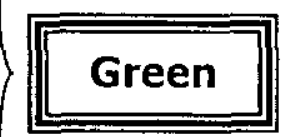

PERFORMANCE MEASURES: GW/VZ

None planned in FroO.

\section{STRETCH AND SUPERSTRETCH GOALS: GW/ZZ}

\begin{tabular}{|c|r|r|}
\hline \multicolumn{1}{|c|}{ FYOO "Stretch" Goals } & \multicolumn{1}{c|}{$\begin{array}{c}\text { Scope } \\
\text { Dollars (K) }\end{array}$} & $\begin{array}{r}\text { Approved } \\
\text { BCPs (K) }\end{array}$ \\
\hline $\begin{array}{l}\text { Groundwater Management-Resin Purchase: } \\
\text { (1) Resin Purchase (BCP-20115) }\end{array}$ & $\$ 406.6 \mathrm{~K}$ & $\$ 406.6 \mathrm{~K}$ \\
\hline $\begin{array}{l}\text { Complete Partitioning of Interwell Treatment at 200-ZP-1 } \\
\text { and 200-ZP-Z }\end{array}$ & $\$ 299.4 \mathrm{~K}$ & $\$ 0.0 \mathrm{~K}$ \\
\hline S/Total GW-Vadose Zone Stretch Goals: & $\$ 706.0 \mathrm{~K}$ & $\$ 406.6 \mathrm{~K}$ \\
\hline
\end{tabular}




\section{ENVIRONMENTAL MANAGEMENT PERFORMANCE REPORT ENVIRONMENTAL RESTORATION CONTRACT MAY 2000}

STRETCH AND SUPERSTRETCH GOALS continued: $G W / V Z$

\begin{tabular}{|c|c|c|}
\hline FYoo "Superstretch" Goals & $\begin{array}{c}\text { Scope } \\
\text { Dollars (K) }\end{array}$ & $\begin{array}{l}\text { Approved } \\
\text { BCPs (K) }\end{array}$ \\
\hline $\begin{array}{l}\text { Provide Permanent Solution for Hanford Groundwater } \\
\text { Plumes }\end{array}$ & $\$ 750.0 K$ & $\$ 0.0 K$ \\
\hline $\begin{array}{l}\text { Complete Remediation of } 60 \mathrm{Sq} \text {. Mi. of Hanford Site: } \\
\text { (1) Verify and administratively close } 170 \text { wells } \\
\text { (2) Decommissioning of } 200 \text { wells }\end{array}$ & $\begin{array}{l}\$ 450.0 \mathrm{~K} \\
\$ 900.0 \mathrm{~K}\end{array}$ & $\begin{array}{l}\$ 0.0 K \\
\$ 0.0 K\end{array}$ \\
\hline S/Total GW - Vadose Zone Super Stretch Goals: & $\$ 2,100.0 K$ & $\$ 0.0 K$ \\
\hline
\end{tabular}

Status: Plan and estimate developed, current work efforts focusing on stretch activities at this time.

\section{PROJECT STATUS (COST/SCHEDULE/MAJOR BASELINE CHANGE): GW/NZ}

\section{- Schedule:}

\begin{tabular}{|c|c|c|c|c|}
\hline \multirow{2}{*}{ Groundwater Vadose Zone Integration } & BCWS & BCWP & Variance & \\
\hline & $\$ K$ & $\$ \mathbf{k}$ & $\$ \mathbf{K}$ & \\
\hline ER02 200 Area Remedial Actions & 2,823 & 2,643 & -180 & \\
\hline EROS Groundwater Management & 12,035 & 10,281 & $-1,754$ & Green \\
\hline VZ01 Groundwater/Vadose Zone & 5,404 & 4,470 & -934 & \\
\hline TOTAL Groundwater & 20,262 & 17,394 & $-2,868$ & \\
\hline
\end{tabular}

PBS-ER-02 - 200 Area Remedial Action (Assessment)

Schedule Variance $=[(-\$ 180 K) ;(-6.4 \%)]$ [Last Month: $-\$ 111 K ;-3.8 \%]$

Cause: Miscellaneous assessment work rescheduled.

Resolution: None required.

PBS-ER-OB - Groundwater Management

Schedule Variance $=[(-\$ 1754 K) ;(-14.6 \%)][$ Last Month: $(-\$ 2024 K) ;(-19.9 \%)]$

Cause: Groundwater Monitoring sample collection and analysis (PNNL) fell behind schedule in October/November, due to difficulties in obtaining NCO bargaining unit personnel, and has not yet recovered.

Resolution: Additional NCOs have been added and a recovery schedule implemented; unexpected sampling at the 618-11 Burial Ground will impact recovery timing; full recovery is not expected before summer.

Cause: Waste shipments and regeneration at Pump and Treat units have been delayed due to waste disposition issue; no significant impact.

Resolution: Waste regeneration shipments have been scheduled through Fluor Hanford.

Cause: Delays in shipment of waste to ERDF.

Resolution: Will recover when waste issues resolved and shipped. 


\title{
ENVIRONMENTAL MANAGEMENT PERFORMANCE REPORT ENVIRONMENTAL RESTORATION CONTRACT MAY 2000
}

(7) PROJECT STATUS (COST/SCHEDULE/MAJOR BASELINE CHANGE) continued: $G W / V Z$

\begin{abstract}
Cause: Resin purchase and resin regeneration delayed due to waste issues.
Resolution: Resin has been purchased so schedule variance will correct itself. Regeneration issues resolved.
\end{abstract}

Cause: Waste collection and offsite waste analysis slower than anticipated.

Resolution: Labor end contract issues have been resolved, recovery progressing but uncertain if full recovery can be achieved.

PBS-VZ-O1 - Groundwater/Vadose Zone

Schedule Variance $=[(-\$ 934 K) ;(-17.3 \%)][$ Last Month: $(-\$ 811 K) ;(-18 \%)]$

Cause: Peer review subpanel meeting was rescheduled; National Academy of Science meeting was rescheduled.

Resolution: Expect full recovery.

Cause: Resource availability has delayed system characterization efforts.

Resolution: Additional staffing was added March 28; expect full recovery.

Cause: Resource availability delayed science and technology efforts on Roadmap planning and transport modeling.

Resolution: Subcontract staff has been added to supplement existing staff; expect late completion of Roadmap but well within FY 2000; expect recovery of transport modeling by September.

\section{- Cost:}

\begin{tabular}{|c|r|r|r|}
\hline \multirow{2}{*}{ Groundwater Vadose Zone Integration } & \multicolumn{1}{c|}{ BCWP } & \multicolumn{1}{c|}{ ACWP } & Variance \\
\cline { 2 - 4 } & \multicolumn{1}{c|}{$\$ \mathrm{~K}$} & \multicolumn{1}{|c|}{$\$ \mathrm{~K}$} & \multicolumn{1}{|c|}{$\$ \mathrm{~K}$} \\
\hline ER02 200 Area Remedial Actions & 2,643 & 1,942 & 701 \\
\hline ERO8 Groundwater Management & 10,281 & 9,835 & 446 \\
\hline VZO1 Groundwater/Vadose Zone & 4,470 & 4,269 & 201 \\
\hline roTAL Groundwater & 17,394 & 16,046 & $\mathbf{1 , 3 4 8}$ \\
\hline
\end{tabular}

PBS-ER-02 - 200 Area Remedial Action (Assessment)

Cost Variance $=\left[+\$ 701 K_{;}+26.5 \%\right]$ [Last Month: $\left.+\$ 964 K ;+34.6 \%\right]$

Cause: Efficiencies learned in prior work were applied to Gable Mountain and B-Pond test pit trenching, resulting in savings; number of samples required was reduced. Borehole drilling was combined with RCRA drilling resulting in cost savings.

Resolution: Savings will be used to perform other remediation work.

PBS-ER-08-Groundwater Management Cost Variance $=[+\$ 446 K ;+4.3 \%$ ] [Last Month: $+\$ 259 K ;+3.2 \%$ ]

Cause: Fewer support personnel were required than planned to support data evaluation, GIS support, and statistical analysis.

Resolution: Savings will be used to perform other remediation work.

PBS-VZ-O1 - Groundwater/Vadose Zone

Cost Variance $=\left[+\$ 201 K_{;}+4.5 \%\right][$ Last Month: $+\$ 150 \% ;+4.1 \%]$ 


\section{ENVIRONMENTAL MANAGEMENT PERFORMANCE REPORT ENVIRONMENTAL RESTORATION CONTRACT MAY 2000}

PROJECT STATUS (COST/SCHEDULE/MAJOR BASELINE CHANGE) continued: GW/VZ

Cause: Costs of system assessment capability development less than planned.

Resolution: Savings will be used to perform ather remediation work.

\section{REGULATORY ISSUES: $G W / V Z$}

200-ZP-2: Regulatory agencies desire continued operation of the 200-ZP-2 vapor extraction unit (not included in DWP).

Status: Project personne/ met with EPA (Doug Sherwood), to discuss the need to restart ZP-Z pending completion of the cost estimate to perform the Portitioning Interwell Tracer Test (PITT) test. Decision to be made to either restart ZP-2 or initiate the PITT test by June 1. PITT test estimate is complete and BHI internal management review is in process. Forecasted date to send to $D O E$ is May $\mathcal{B}$. A BCP for $Z P$-2 restart has also been completed.

200-UP-1: Regulatory agencies desire continued operation of the 200-UP-1 pump and treat system (not included in DWP).

Status: BHI received direction from the Contracting Officer Representative (COR) to extend operations until the end of FY 2000. The Groundwater Project will also include operations of UP-1 per FY 2001 -FY 2003 DWP. BCP-20163 has been approved to extend operations to the end of FY 2000.

Well Installation: RL provide funds for CY-2000 GW RCRA Well installation.

Status: On April 19, agreement was reached with Ecology to install fifteen RCRA groundwater monitoring wells for calendar year 2000 (TPA Milestone M-24-00L). Specific well locations need to be identified. Also, Ecology agreed milestone could be extended beyond December 31, if required.

200 Area Assessment: RL direction is needed on proceeding with the 200-PW-2 Work Plan. Initiating work on the 200-PW-Z OU is not consistent with funding levels nor RL's path forward strategy for the 200 Area.

Status: The 200-PW-2 Work Plan is currently on hold pending deferral of 200-PW-2 activities, and will require a TPA change. TPA Milestone M-13-25 requires that the draft A 200-PW-2 work plan be submitted to the regulators by December 31. Meeting this milestone requires that work plan/DQD activities be initiated on May 1. Briefing with DOE management took place on April 21.

618-11 Burial Ground Tritium: A high tritium value was identified in a monitoring well for the 618-11 Burial Ground.

Status: A DQO summary report for the Phase II plume investigation near Burial Ground 618-11 is currently being revised. A brief plan of key characterization activities was summarized from this report to aid in review in document review. The Phase I report on the February sampling event is under review.

EXTERNAL ISSUES (i.e. HAB, Congress, etc.): $G W / Z$

None identified at this time.

\section{DOE-RL \& HQ ISSUES/REQUESTS (not covered elsewhere): GW/VZ}

None identified at this time.

INTEGRATION ACTIVITIES: $G W / V Z$

None identified at this time. 


\section{Surveillance/Maintenance and Transition Project (SM\&T)}




\section{ENVIRONMENTAL MANAGEMENT PERFORMANCE REPORT ENVIRONMENTAL RESTORATION CONTRACT \\ MAY 2000}

\section{SECTION C - TRANSITIONING THE CENTRAL PLATEAU}

Financial / Performance measures data as of month-end March.

All other data as of April 20, unless otherwise noted.

\section{Surveillance/Maintenance \& Transition Project (SMBT):}

ACCOMPLISHMENTS: SM\&T

Completed mobilization of equipment and began the sealing of the passive vents at RARA sites work ( 7 of 84 identified have been sealed).

Removal of legacy waste is approximately $90 \%$ complete at KE Reactor.

At 105-KW, about 52 of 68 boxes have been opened and approximately 280 of 370 fuel baskets have been packaged and are ready to be shipped to ERDF. Removal of all waste is approximately $45 \%$ complete.

WDOH approved the final design package for the new water treatment plant. The subcontractor continues to install the new piping system. Phase I deactivation of the existing water plant continues (Stretch Goal).

Completed the task instruction for the Pu Loadout Hood work and began developing the Readiness Assessment (RA) plan.

Continue to move equipment off the cell cover blocks, lifting the cellblocks, videoing the contents and utilizing the gamma camera to take radiological profiles of the cells in support of CDI FS. Completed development of the task instructions and work packages for the railroad tunnel door repair and railroad tunne/ concrete sampling activities.

Completed the RARA Annual Report and the ERC Spring Re-vegetation activities.

Continue to develop the task instruction and work package for $183 \mathrm{KE} / \mathrm{KW}$ Acid Tanks stabilization work.

Began the REDOX railroad cut interim stabilization and commenced backfilling. Began to

backfill/downpost all of the outdoor contaminated areas around REDOX.

SAFETY/ISMS/CONDUCT OF OPS: SM\&T

See Cross-Cutting Package.

\section{BREAKTHROUGHS/OPORTUNITIES FOR IMPROVEMENT: SM\&T}

None identified at this time.

\section{LONG-TERM (6 MONTHS PLUS) IMPORTANT TTEMS: SM\&T}

None identified at this time.

\section{MAJOR COMMITMENTS: SMQT}

- DOE Secretarial:

None identified at this time.

- DOE EM Performance Agreement:

None identified at this time.

- TPA Milestones:

None identified at this time.

- DNFSB Commitment:

None identified at this time. 


\section{ENVIRONMENTAL MANAGEMENT PERFORMANCE REPORT ENVIRONMENTAL RESTORATION CONTRACT \\ MAY 2000}

\begin{tabular}{|l|l|l|}
\hline \multicolumn{2}{|c|}{ PERFORMANCE OBJECTIVES: SM\&T } & \multicolumn{1}{|c|}{ Status } \\
\hline $\begin{array}{l}\text { Oestore the River Corridor for } \\
\text { Multiple Uses }\end{array}$ & $\begin{array}{l}\text { Performance Indicator } \\
\text { Deactivation and preparation } \\
\text { for decommission. }\end{array}$ & $\begin{array}{l}\text { KE/KW legacy waste removal } \\
\text { recovery behind schedule } \\
\text { condition due to additional } \\
\text { regulatory requirements and } \\
\text { resource allocation } \\
\text { RCT's/manual). BCP-20075 } \\
\text { approved to extend schedule } \\
\text { by three weeks. Baseline work } \\
\text { is projected to be completed } \\
\text { per PI requirements. }\end{array}$ \\
\hline $\begin{array}{l}\text { Transition Central Plateau to } \\
\text { Support Long-Term Waste } \\
\text { Management }\end{array}$ & $\begin{array}{l}\text { Perform S\&M/risk reduction on } \\
\text { inactive facilities to } \\
\text { eliminate/stabilize } \\
\text { environmental, human health } \\
\text { hazards until D\&D; Perform } \\
\text { CDI activities. }\end{array}$ & $\begin{array}{l}\text { CDI baseline work projected to } \\
\text { be completed per PI } \\
\text { requirements. DoE-Waste } \\
\text { Management funding shontfalls } \\
\text { will require scope adjustment. }\end{array}$ \\
\hline
\end{tabular}

PERFORMANCE MEASURES: SM\&T

None planned in FYOO.

STRETCH AND SUPERSTRETCH GOALS: SM\&T

\begin{tabular}{|l|r|r|}
\hline \multicolumn{1}{|c|}{ FY00 "Stretch" Goals } & \multicolumn{1}{|c|}{$\begin{array}{c}\text { Scope } \\
\text { Dollars (K) }\end{array}$} & $\begin{array}{r}\text { Approved } \\
\text { BCPs (K) }\end{array}$ \\
\hline $\begin{array}{l}\text { Deactivate 183-N Water Treatment Plant (Phase I) } \\
\text { BCP-20111) } \\
\text { Deactivate 183-N Water Treatment Plant (Phase II) } \\
\text { (BCP-20175) }\end{array}$ & $\$ 131.0 \mathrm{~K}$ & $\$ 131.0 \mathrm{~K}$ \\
\hline Asbestos Abatement \& Repairs (100, 200, \& 300 Areas) & $\$ 158.8 \mathrm{~K}$ & $\$ 494.0 \mathrm{~K}$ \\
\hline $\begin{array}{l}\text { Complete the CDI Technical Work to Support the Phase II } \\
\text { Feasibility Study }\end{array}$ & $\$ 625.0 \mathrm{~K}$ & $\$ 0.0 \mathrm{~K}$ \\
\hline \multicolumn{1}{|c|}{ S/Total SM\&T - Facility Transition Stretch Goals: } & $\$ 1408.8 \mathrm{~K}$ & $\$ 289.8 \mathrm{~K}$ \\
\hline
\end{tabular}

Green 


\section{ENVIRONMENTAL MANAGEMENT PERFORMANCE REPORT ENVIRONMENTAL RESTORATION CONTRACT \\ MAY 2000}

PROJECT STATUS (COST/SCHEDULE/MAJOR BASELINE CHANGE): SM\&T

- Schedule:

\begin{tabular}{|c|r|r|r|}
\hline Surveillance/Maintenance \& Transition Project & \multicolumn{1}{|c|}{ BCWS } & \multicolumn{1}{|c|}{ BCWP } & Variance \\
\cline { 2 - 4 } & \multicolumn{1}{|c|}{$\$ \mathbf{K}$} & $\mathbf{\$ K}$ & \multicolumn{1}{|c|}{$\mathbf{K}$} \\
\hline ERO5 Surveillance \& Maintenance & 6,410 & 5,904 & -506 \\
\hline EROT Long-Term Surveillance \& Maintenance & 4 & 6 & 2 \\
\hline TOTAL SM\&T & 6,414 & 5,910 & -504 \\
\hline
\end{tabular}

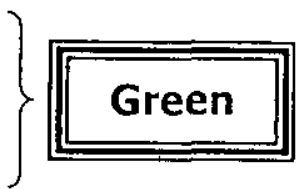

PBS-ER-05 - Surveillance and Maintenance

Schedule Variance $=[(-\$ 506 K) ;(-7.9 \%)]$ [Last Month: $(-\$ 498 K) ;(-9.5 \%)]$

Cause: Preparation and submittal of an unplanned Waste Management Plan to Regulators for 105-KE legacy waste removal delayed start of field activities.

Resolution: The Waste Management Plan has been completed, and field activities commenced in late December; additional craft resources were added to help recover schedule.

Cause: COI process cell access work delayed due to canyon crane being down for repairs.

Resolution: Crane NDE completed - recommendations implemented; schedule expected to be recovered.

Cause: 195-5 sump work behind schedule because access could not be achieved as originally planned.

Resolution: Work package is complete. WDOH agreed that NOC (air permit) is not required. BCP being written for change in scope.

PBS-ER-OT - Long-Term Surveillance and Maintenance (BCWS \$47K for FY 2000)

Schedule variance $=N / A$

- Cost:

\begin{tabular}{|c|r|r|r|}
\hline Surveillance/Maintenance \& Transition Project & BCWP & ACWP & Variance \\
\cline { 2 - 4 } & \multicolumn{1}{|c|}{$\$ \mathrm{~K}$} & $\$ \mathrm{~K}$ & $\$ \mathrm{~K}$ \\
\hline ERO5 Surveillance \& Maintenance & 5,904 & 6,266 & -362 \\
\hline EROT Long-Term Surveillance \& Maintenance & 6 & 10 & -4 \\
\hline TOTAL SM\&T & 5,910 & 6,276 & -366 \\
\hline
\end{tabular}

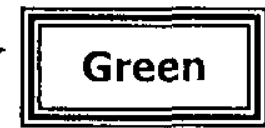

PBS-ER-05 - Surveillance and Maintenance

Cost Variance $=[(-\$ 362 K) ;(-6.1 \%)][$ Last Month: $(-\$ 161) ;(-3.4 \%)]$

Cause: Canyon crane NDE testing and repair not anticipated; PUREX shotcreting and roof inspections were unanticipated work.

Resolution: BCP approved for NDE testing; roof repair work trended.

Cause: 200 Area miscellaneous waste management and increased disposal costs for PHMC recharacterization.

Resolution: Project monitoring costs. Trends recorded.

Cause: Underruns on B Plant S\&M and RARA stabilization from work practice efficiencies. 


\section{ENVIRONMENTAL MANAGEMENT PERFORMANCE REPORT ENVIRONMENTAL RESTORATION CONTRACT MAY 2000}

PROJECT STATUS (COST/SCHEDULE/MAJOR BASELINE CHANGE) continued: SM\&T

Resolution: Underrun will be utilized for other $E R$ work.

PBS-ER-07 - Long-Term Surveillance and Maintenance (BCWS \$47K for FY 2000)

Cost Variance $=N / A$

REGULATORY ISSUES: SM\&T

None identified at this time.

EXTERNAL ISSUES (i.e. HAB, Congress, etc.): SM\&T

None identified at this time.

DOE-RL \& HQ ISSUES/REQUESTS (not covered elsewhere): SM\&T

B-Plant/Purex Roof Funding: Ensure funding is provided by Transition Projects per MOUs, to support roof repair commitments for $B$-Plant and Purex. Facilities have transitioned to ER with the commitment to fund these repairs from the releasing Project.

Status: Funding for roof repairs has not been included within the current above-the-line Integrated Priority Lists (IPL) targets.

Stack Ventilation: Problems with stack ventilation, retired filters, and other issues documented in letter, M. C. Hughes to R. Gerton, 9/28/99, "Remaining Issues for the Transition of the B-Plant Facility from DOE-Transition to ER".

Status: Facility transferred to ERC September 30, 1999. MOA with open items assigned cost/schedule responsibility received September 30. Original MOA schedule not met. The ventilation specialists brought in by Fluor Hanford has determined the resonant frequency of the ductwork matches the low flow harmonics of the fan, thus setting up severe vibrations in the ductwork. Solution is not to operate the fan in low flow conditions utilizing the input damper for modulation. Engineering report and path forward to repair the ductwork is pending; fieldwork implementation to follow.

\section{INTEGRATION ACTIVITIES: SM\&T}

None identified at this time. 


\section{Table of Contents}

INTRODUCTION 1

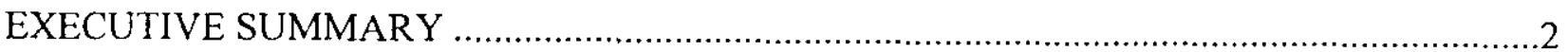

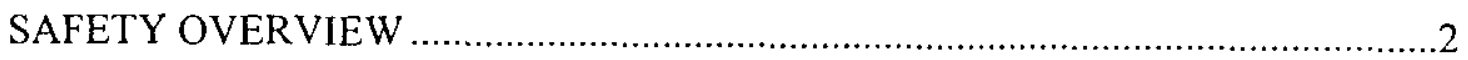

SIGNIFICANT SAFETY AND HEALTH EVENTS ..........................2

VOLUNTARY PROTECTION PROGRAM ..................................... 4

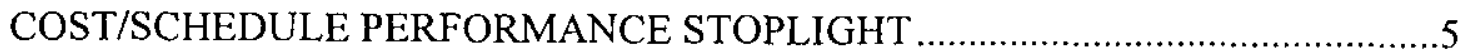

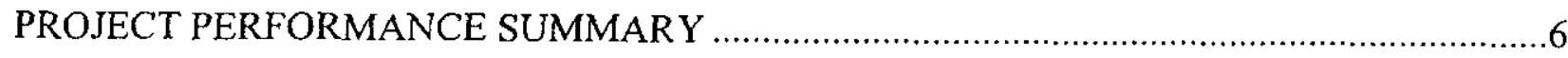

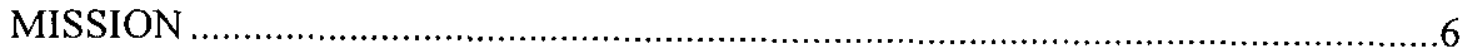

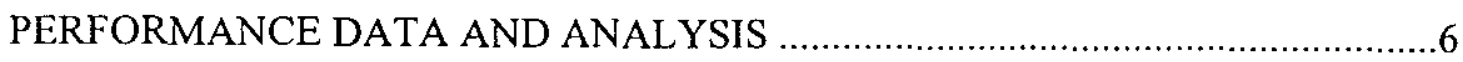




\section{Pacific Northwest National Laboratory Environmental Management Performance Report}

May 2000

PREPARED FOR THE U.S. DEPARTMENT OF ENERGY, RICHLAND OPERATIONS OFFICE OFFICE OF ENVIRONMENTAL MANAGEMENT

Pacific Northwest National Laboratory Operated for the U.S. Department of Energy by Battelle Memorial Institute 
$T$ his document provides the Department of Energy Richland Operations Office (DOE-RL) with a report of the Pacific Northwest National Laboratory (PNNL) performance by Battelle Memorial Institute and its subcontractors.

In Section A, the Executive Summary, text and graphics report the safety metrics status for all PNNL activities. Senior management's overall performance assessment of all Environmental Management activities conducted at PNNL is presented in a stoplight chart.

Section B, Project Performance Summary, provides a brief summary of the month's performance for the PNNL lead activity, PNNL Waste Management (PBS RL-ST01). Summary analyses pertaining to PNNL's support to other Project Baseline Summaries (PBSs) are addressed in the contractor's report having lead responsibility for that scope.

Unless otherwise noted, information in this report is current as of March 26, 2000. 
This section provides an executive-level summary of performance information and is intended to bring to Management's attention that information considered to be most noteworthy. The section begins with overviews of safety, followed by a stoplight chart on overall performance.

\section{Safety Overview}

$\mathrm{T}$ The focus of this section is on documenting trends in work-related injuries and illnesses.

Improvements in these rates result from the efforts of the PNNL workforce as they implement the Integrated Environment, Safety, and Health (ES\&H) Management System (ISMS), work towards achieving Voluntary Protection Program (VPP) "star" status, and accomplish work through Enhanced Work Planning (EWP). Safety and health statistical data are presented in this section followed by completed actions and planned actions for the PNNL VPP.

\section{Significant SafeTy and Health EVENTS}

Currently the PNNL Total Recordable Case Incidence Rates appear to be cycling periodically around the 2.22 baseline average and show no significant deviations from the average. The Lost Workday Case Incidence Rates demonstrate that, for eight of the past ten months, the rates have been below the 0.98 average. No notable changes have occurred in the Lost Workday Severity Rates since the last report.

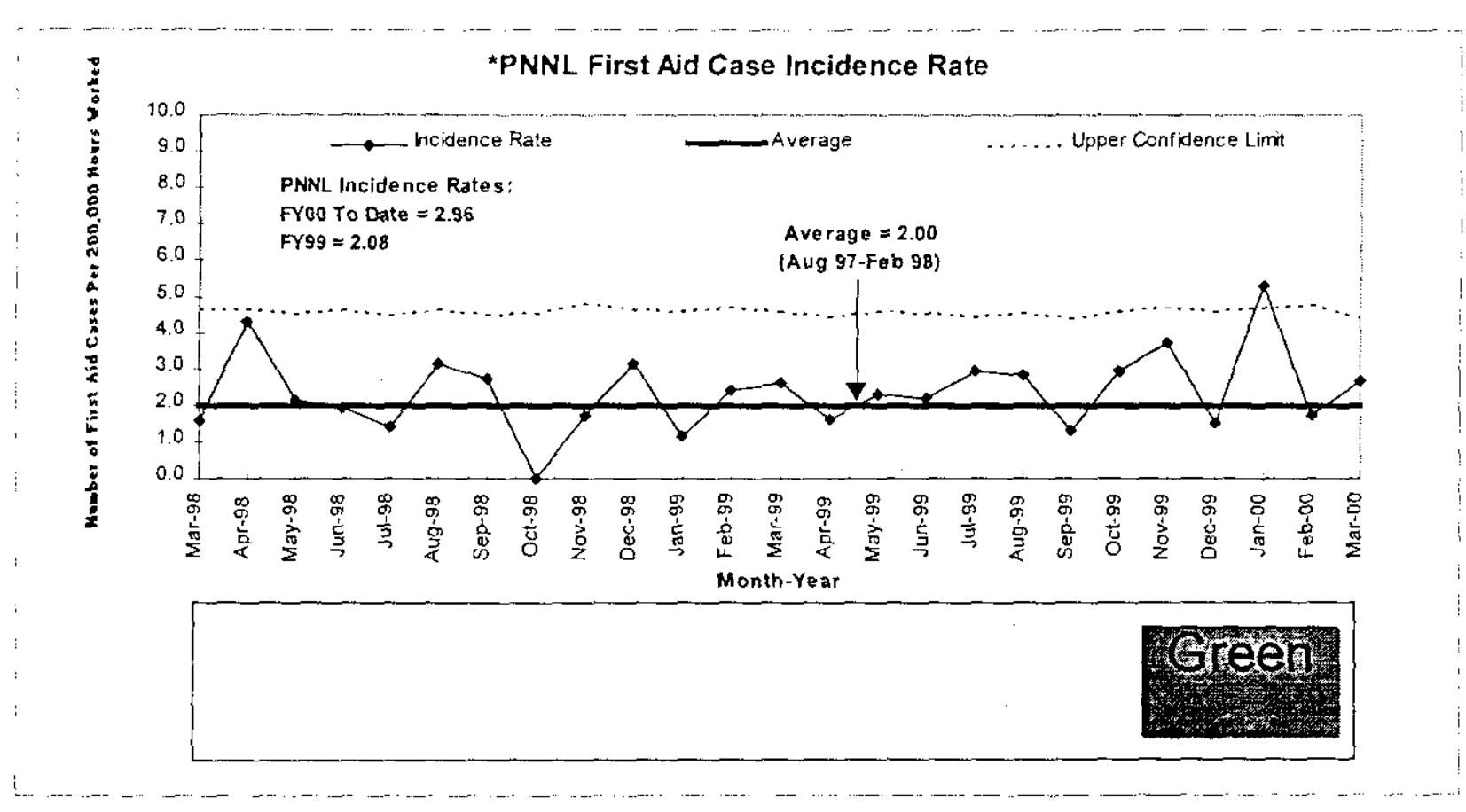


*PNNL Total Recordable Case Incidence Rate
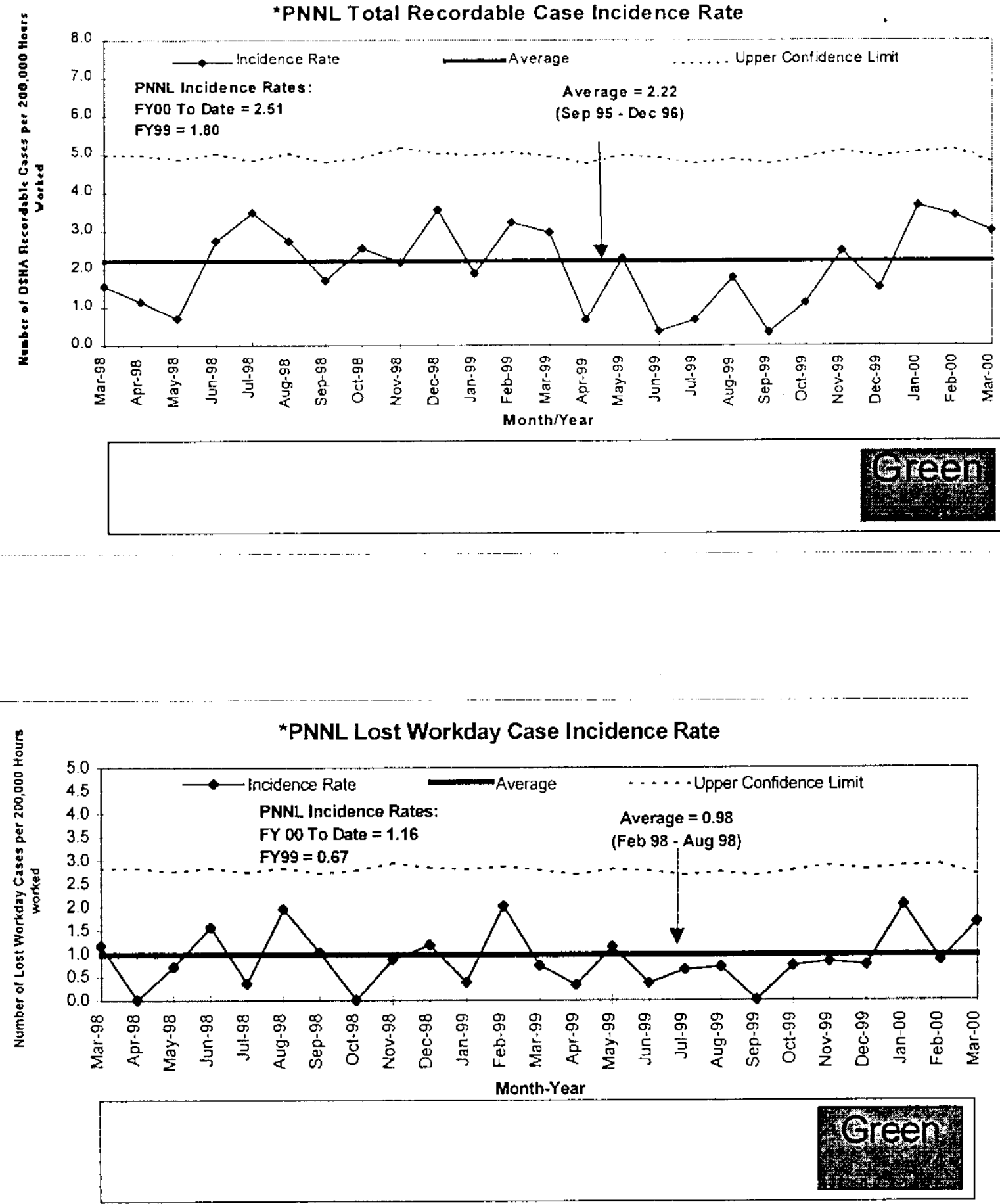

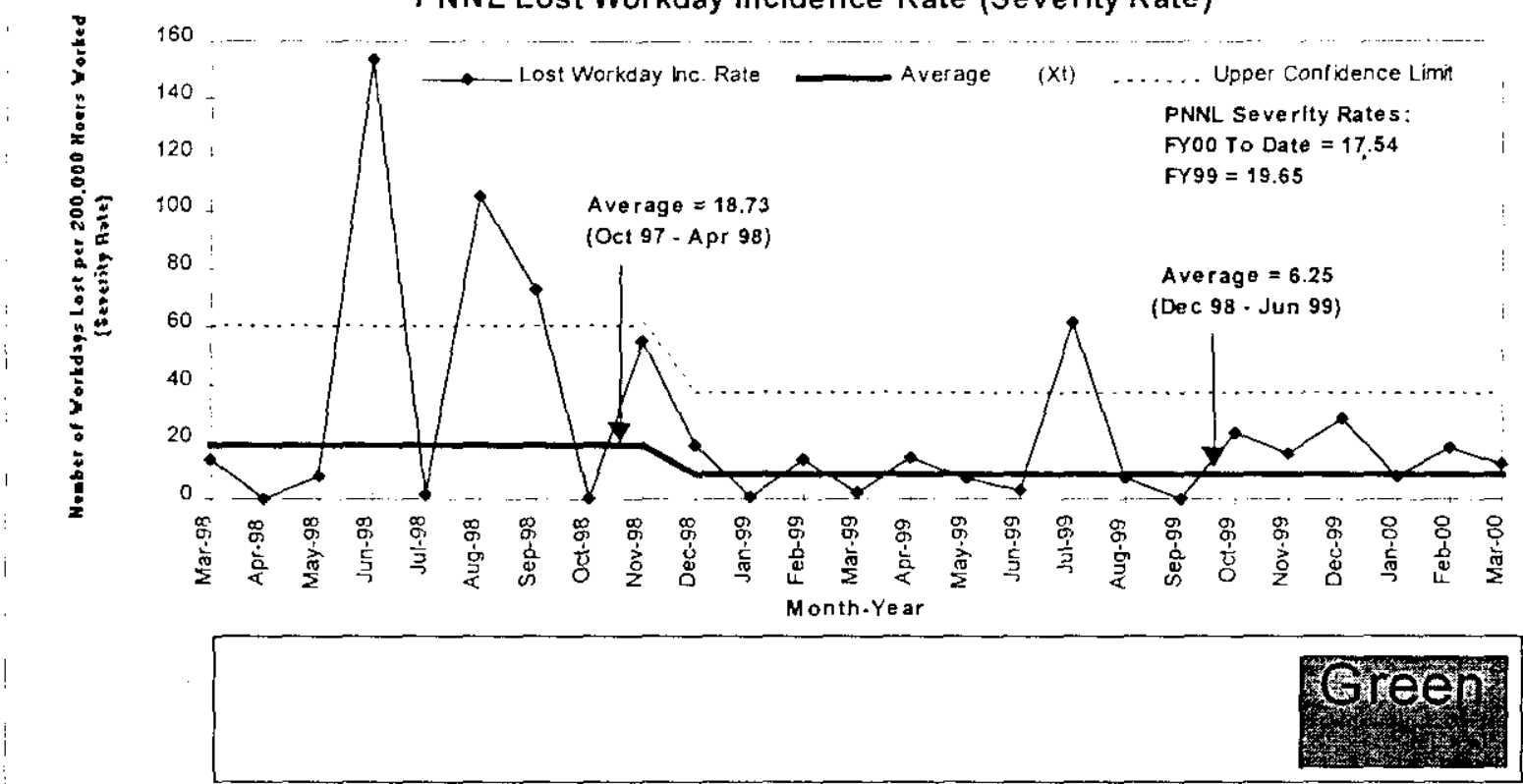

\section{Voluntary Protection Program}

PNNL is actively pursuing "star" status and is scheduled to submit a VPP "star" status application in September 2000.

PNNL VPP accomplishments include:

- increased worker communications on VPP including the development of a PNNL VPP web page (http://www.pnl.gov/vpp/)

- formation of a VPP steering committee and issuance of a PNNL VPP Management Plan

- PNNL worker participation at the VPP conference in Washington D.C.

Plans for the remainder of this year include increasing communications on VPP and participation in the Health and Safety Exposition 2000 (Pasco, WA). 


\section{Cost/Schedule Performance Stoplight}

The following rating reflects overall performance for activities conducted by PNNL. (Narrative not required when rating is green.)

Green: Satisfactory

Yellow: Significant improvement required

Red: Unsatisfactory 
This section provides cost and schedule performance, any significant issues, and upcoming baseline change requests for the period covered. In fiscal year (FY) 2000, Battelle Memorial Institute has lead responsibility over PBS RL-ST01, PNNL Waste Management WBS 1.7.1.

\section{Mission}

WBS 1.7.1 provides PNNL with waste management services and compliant operations in support of science and technology development for the multiprogram needs of the U.S. Department of Energy (DOE) Complex. These services include:

- essential surveillance and maintenance of DOE laboratory facilities assigned to PNNL for safe containment of radioactive and hazardous materials

- infrastructure required to manage wastes and effluents currently generated at the PNNL

- operational compliance services to meet regulatory requirements and operating permits including environment, safety, and health regulations

- management of legacy wastes and contamination remaining from past PNNL research operations.

\section{Performance Data and Analysis}

As of March 26, 2000 the cumulative cost of $\$ 6.1$ million and a positive cost variance of $\$ 0.4 \mathrm{M}$ results from reduced overhead rates and delayed billings. A change request is in process to revise the basis of estimate and align budget and funds. It is expected that the baseline activities will be completed within the funding allocation. The primary reasons for the cumulative schedule variance of negative $\$ 0.6 \mathrm{M}$ are described below:

- Difficulties in completing the high-dose waste container design delayed the initiation of the fabrication of the drum-handling system. Preliminary cost estimates for fabricating the drums have been obtained. Meetings have been held with other contractors regarding the shipping and receiving of the drums later this year. The actual disposal of the high-dose waste should occur as scheduled at the end of the fiscal year.

- The RLWS delay affected planned cask shipments to the 200 Area for final disposition. A change request is in process to delete waste disposal scope affected by RLWS delays.

All post-start activities have been completed on Radioactive Liquid Waste System with the exception of the final inspection of the existing tie-ins by Science Applications International Corporation (SAIC). The SAIC inspection will be completed after the first usage of the RLWS lines. A letter dated March 22, 2000 was sent to DOE-RL to document completion of the poststart activities and PNNL's intentions to add waste and operate the modified Radioactive Liquid Waste System in the RPL. 


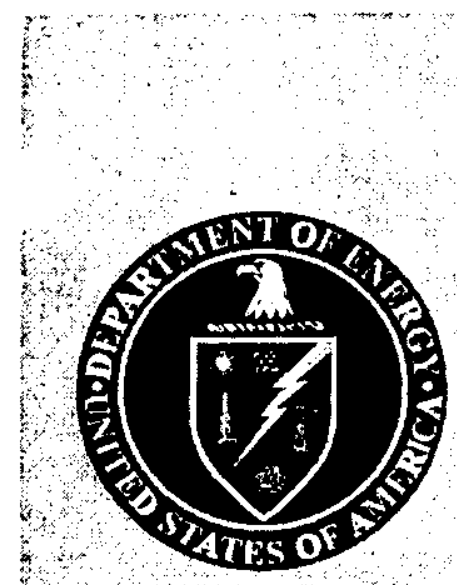

\section{Regulatory Unit}

\section{Monthly Performance Report}

March 2000

tomotom

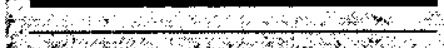

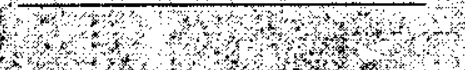

Office of Safety Regulation of the 3.T. TWRS

1. Privatization Contractor

\section{May 2000 \\ Environmental Management Performance Report Submittal}

Richland Operations

P.O. Box 550 chland, Washington ๖9352 


\section{Table of Contents}

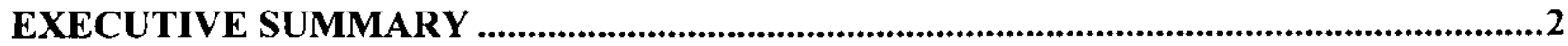

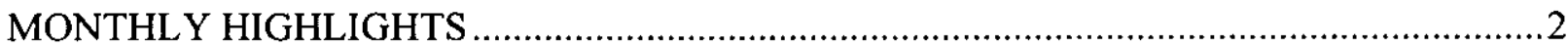

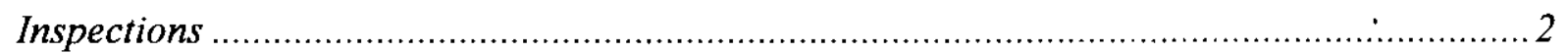

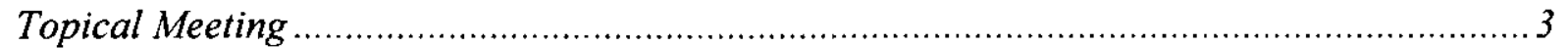

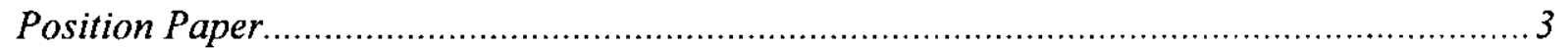

Contract Discussions ......................................................................................... 3

Industrial Health and Safety Program........................................................................ 4

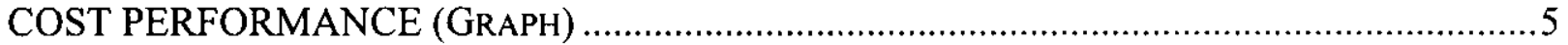

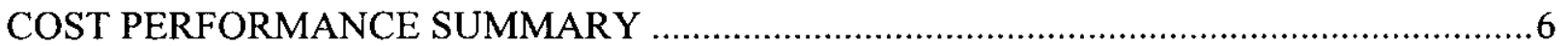

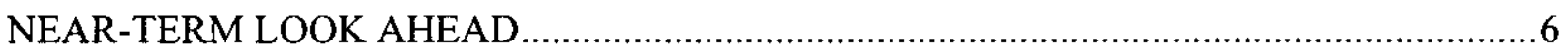

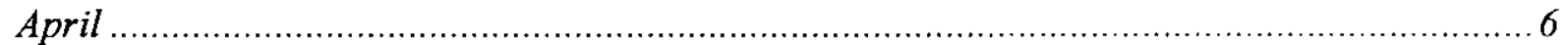

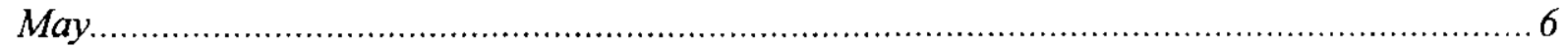

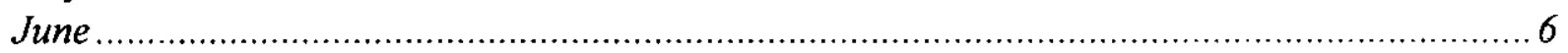

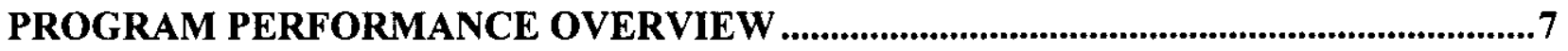

PERFORMANCE SUMMARY (ChART) - PROGRAM DIRECTION AND PROGRAM SUPPORT ...... 8

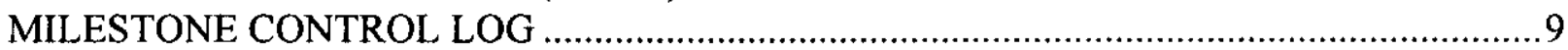

FULL-TIME EQUIVALENCY PROFILE (GRAPH) ................................................... 10

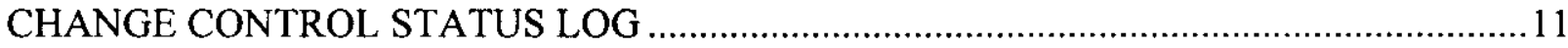




\section{EXECUTIVE OVERVIEW}




\section{EXECUTIVE SUMMARY}

Work continues to resolve significant issues prior to proceeding with Part B-2. During the reporting period, the Dose Assessment Methodology issue was closed following the RU's approval of the BNFL revised Dose Assessment Methodology. Other key issues being resolved are authorization basis (AB) maintenance, schedule for safety deliverable submission, and adherence to procedures.

The TWRS-P authorization basis maintenance process remains a significant issue. On February 24, BNFL submitted a revised response to the RU inspection findings. On March 1, the RU met with BNFL to discuss their revised response. Following the meeting, the RU determined the information presented lacked sufficient detail to conclude that BNFL's actions would completely address the issue. The RU has issued a Corrective Action Notice requesting a formal plan that provides commitments to specific corrective actions and completion dates. The RU will use the plan as a basis for monitoring progress on resolving the authorization basis maintenance issue. (The corrective action plan, which was received from BNFL on April 14, 2000, is being evaluated.)

BNFL has provided the RU with the impact on the schedule of safety deliverables due to the President's Budget providing fewer set aside funds than requested ( $\$ 450 \mathrm{M}$ versus $\$ 606 \mathrm{M}$ ) for next fiscal year. The major impact is a projected delay in the start of construction from July 2001 to December 2001. Based on this change in the start of construction, BNFL will submit the Construction Authorization Request for RU review and approval on February 1, 2001, two months later than previously planned.

Nearly all of the design phase RU inspections of BNFL have identified procedure compliance problems. To address this concern, BNFL established a team to determine the root causes of this problem. The results were presented to the RU management team during a workshop session. Related to the procedure compliance root cause investigation was an inspection Finding regarding failure to maintain the Authorization Basis (AB). In a second response to this Finding, dated February 24, 2000, BNFL presented a QA recovery plan to address the results of the root cause investigation for both the procedural compliance and $\mathrm{AB}$ maintenance issues. This second response provided BNFL's specific actions to resolve the $\mathrm{AB}$ maintenance Finding. In this response BNFL committed to align the $\mathrm{AB}$ with the Design on or before April 24, 2000. The RU has scheduled an inspection of BNFL's Corrective Action Program during the week of April 24-28, 2000, and among other things, will review the adequacy of BNFL's actions to address the AB maintenance Finding.

\section{MONTHLY HIGHLIGHTS}

\section{Inspections}

The RU performed an inspection of BNFL's Training and Qualification Programs, and identified one Finding. The inspectors found that they were unable to determine the effectiveness of the qualification process due to BNFL's lack of timely reporting. Based upon the review of recent contractor surveillances, self-assessment reports and procedure revisions, it was evident that the training and qualification processes were still undergoing development. The completion of corrective actions from 
BNFL's self-assessment of the training program had begun with a Management Training

Responsibilities and Requirements Orientation course first held on February 29, 2000, and attended by 120 contractor managers and leads.

\section{Topical Meeting}

During the March Topical Meeting the RU and BNFL discussed safety issues associated with the design of the TWRS-P melters and the associated offgas systems. Radioactive hazards were identified associated with the feed, melt, vitrified product, offgas, and NOx emissions from the low activity waste melter. These hazards were identified as significant hazards to plant workers. Strategies to prevent or mitigate the identified hazards were presented by BNFL. The next Topical Meeting is scheduled on April 25, 2000 to discuss chemical hazards.

\section{Position Paper}

The RU issued a Position paper on Conformance with Risk Goals. One component of the TWRS-P integrated safety management (ISM) process is to ensure that the risks from facility operations, including the risks from potential accidents, are limited. The paper describes an acceptable method of demonstrating conformance with the risk goals found in Section 3.0 of DOE/RL-96-0006, Top-Level Radiological, Nuclear, and Process Safety Standards and Principles for TWRS Privatization Contractor. There are three risk goals included in the radiological and nuclear safety objectives toplevel standards document DOE/RL-96-0006, which are:

1. Operations risk goal

2. Accident risk goal

3. Worker accident risk goal

The RU has established positions that describe important aspects of an acceptable method to demonstrate conformance with these goals that consider the origin and intent of the risk goals and the unique characteristics of the TWRS-P facility, the Hanford Site, and the worker population.

\section{Contract Discussions}

The RU finalized its proposed contract changes necessary for Part B-2 of the TWRS-P effort, and provided them to the ORP Contracting Officer. While these changes represent a firm RU position, there remain several areas of contention with BNFL:

1. In the area of non-radiological worker safety and health, BNFL would like to see an inspection program that is modeled after OSHA procedures and is much less intrusive than what is planned.

2. Topical meetings will continue on a quarterly basis following Construction Authorization and will utilize the existing protocol. BNFL would like to weaken the protocol, but the RU believes that it is key to the conduct of an effective Topical meeting in which issue closure is achieved.

3. BNFL is permitted to incrementally submit an authorization request, if justified, but the 
prescribed timeframe for RU review doesn't begin until the last component has been received. BNFL would like the right to reach agreement on a compressed review time. Shortening of the review time must be reserved to the sole discretion of the Regulatory Official, based on the quality and content of the submitted components.

4. The RU position on Back-fits, conformance with which is a contractual requirement of the BNFL ISMP, has been changed to address a new regulatory interpretation of an existing requirement. BNFL has taken a wide-open stance regarding the potential sources of a new interpretation. The RU believes it illogical, a hamstringing of the Regulator, and a communication inhibitor.

\section{Industrial Health and Safety Program}

The RU is continuing to define a comprehensive program for regulating non-radiological worker safety and health (IH\&S). While the start of construction is not scheduled until after the first of the calendar year, BNFL is currently defining and documenting their construction safety program. The RU is scheduled to receive the BNFL "Non-radiological Worker Safety and Health Plan" for review and approval on April 24, 2000. The status of the IH\&S regulatory program is:

- $\quad$ Policy and Memorandum of Agreement (MOA) - these documents are essential to documenting the RU's authority to regulate IH\&S. The final draft documents were issued this month for signature by EH-1, EM-1 and S-3 (Policy only) by memo from the Manager, RL.

- $\quad$ Regulatory Plan - this plan describes the process the RU will follow internally in regulating IH\&S. The Regulatory Plan was sent to BNFL for review and comment on March 3, 2000. No comments have been received to date.

- $\quad$ Position Paper - the RU's position on regulating IH\&S was revised (revision 2) and sent to BNFL for review and comment on March 2, 2000. No comments have been received to date.

- Review Guidance - BNFL comments on the draft review guidance for the Non-radiological Worker Safety and Health Plan were received. The guidance will be revised and issued in early April.

- Review Planning Handbook - A detailed description of how the RU will conduct the review of the April 24, 2000, BNFL submittal was completed and circulated for internal review. The Planning Handbook contains specific assignments by reviewer, detailed review schedules, and expanded guidance to reviewers. The final handbook will be issued in mid-April.

- Inspection Program - the Verification and Compliance Officer and his staff are defining a comprehensive IH\&S inspection program. (The basic scope of the program was provided to BNFL as part of the Regulatory Plan.) 

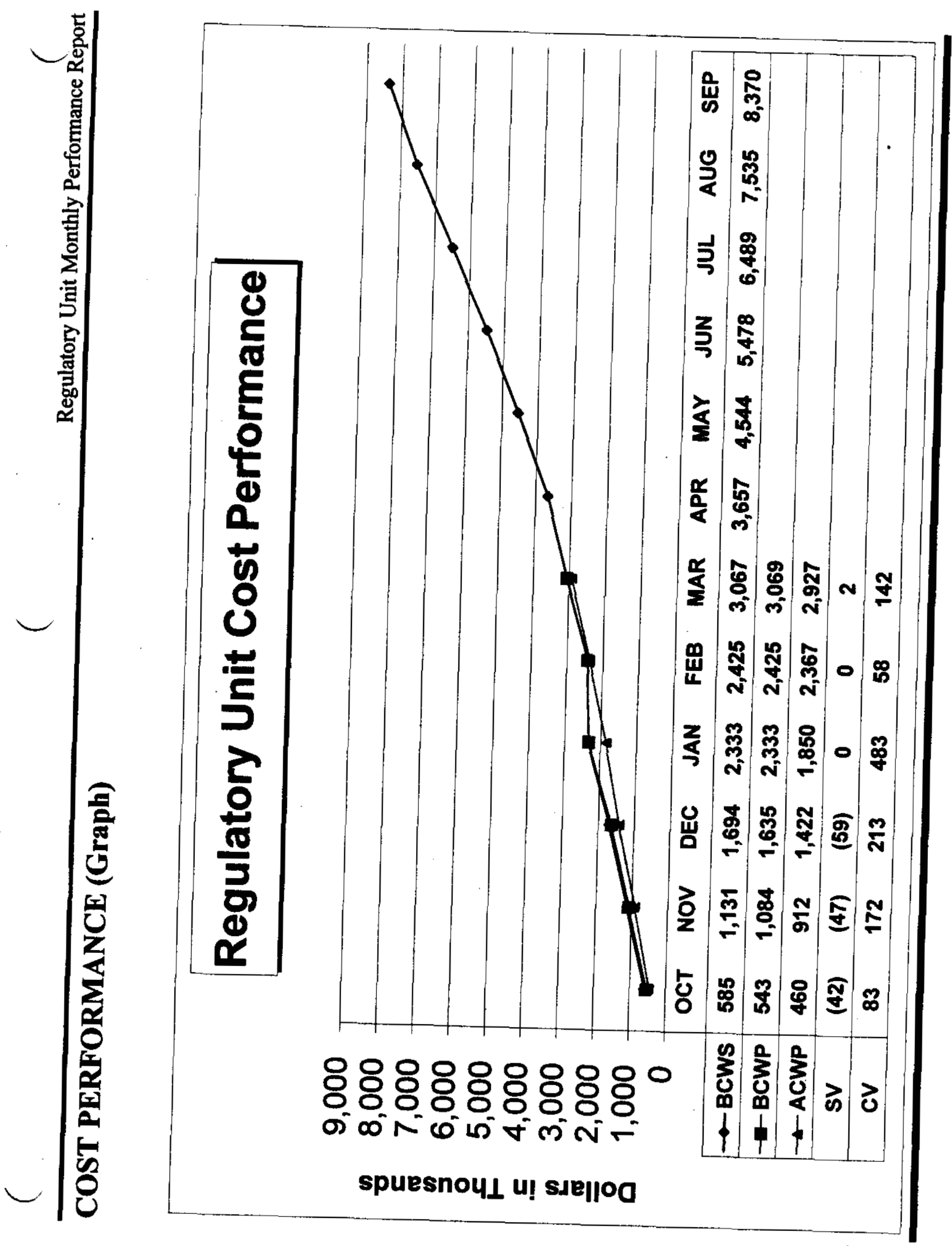


\section{COST PERFORMANCE SUMMARY}

The fiscal year-to-date cost through March reflects a favorable cost variance of $\$ 142 \mathrm{~K}$. This variance is a result of lower than anticipated costs associated with the development of the CAR planning review handbook and the resolving of Topical Issues. All activities are currently performing on or are very close to the baseline schedule.

\section{NEAR-TERM LOOK AHEAD}

\section{April}

- Issue Training \& Qualification Inspection Report

Planned Due Date

- Issue QAPIP Review Handbook

4-05-00

- Conduct Corrective Actions Inspection

$4-14-00$

- Conduct Topical Meeting on Chemical Hazards

$4-24-00$

$4-25-00$

- Commence Review of BNFL IH\&S Program Description

$4-25-00$

\section{May}

- Issue IH\&S Regulatory Plan

$5-11-00$

- Issue SAP Review Handbook

$5-12-00$

- Conduct Standards Implementation Inspection

$5-15-00$

- Issue LCA Review Handbook

$5-17-00$

- Present $14^{\text {th }}$ Quarterly Briefing to Headquarters

$5-18-00$

- Conduct Topical Meeting on $2^{\text {nd }}$ Iteration: Hazards Control Strategies

$5-23-00$

- Issue Corrective Action Inspection Report

June

- Issue CAR Review Handbook

6-09-00

- Conduct QA Inspection

$6-12-00$

- Issue Standards Implementation Inspection Report

$6-19-00$

- Commence Review of BNFL LCA Request

$6-27-00$ 


\section{PROGRAM PERFORMANCE OVERVIEW}




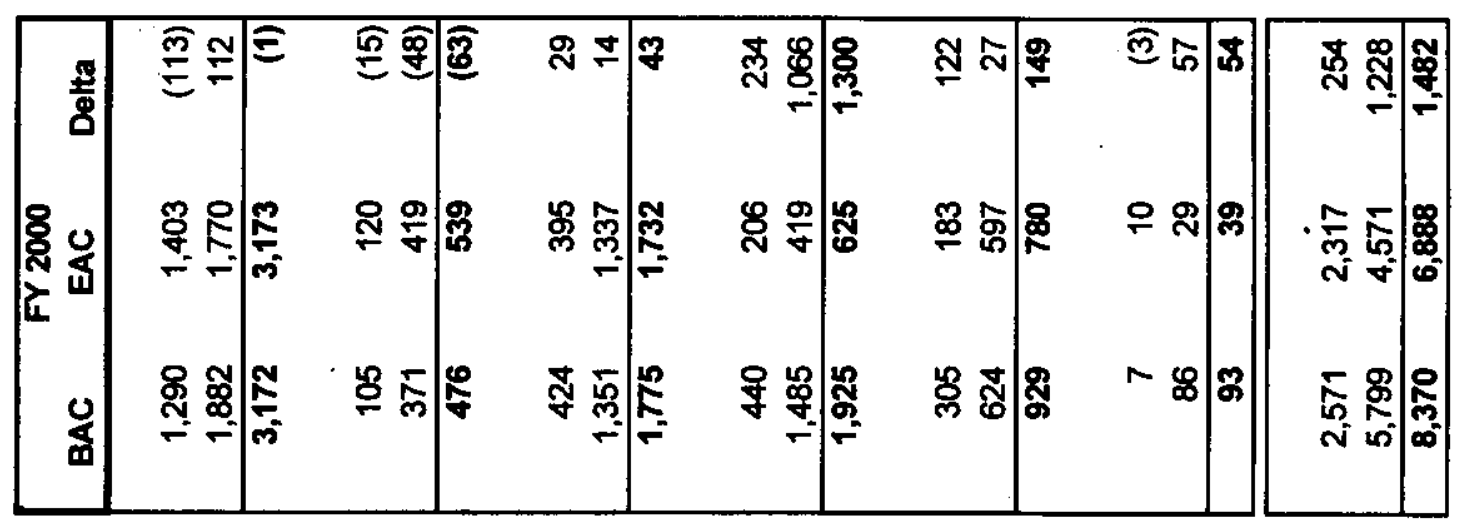

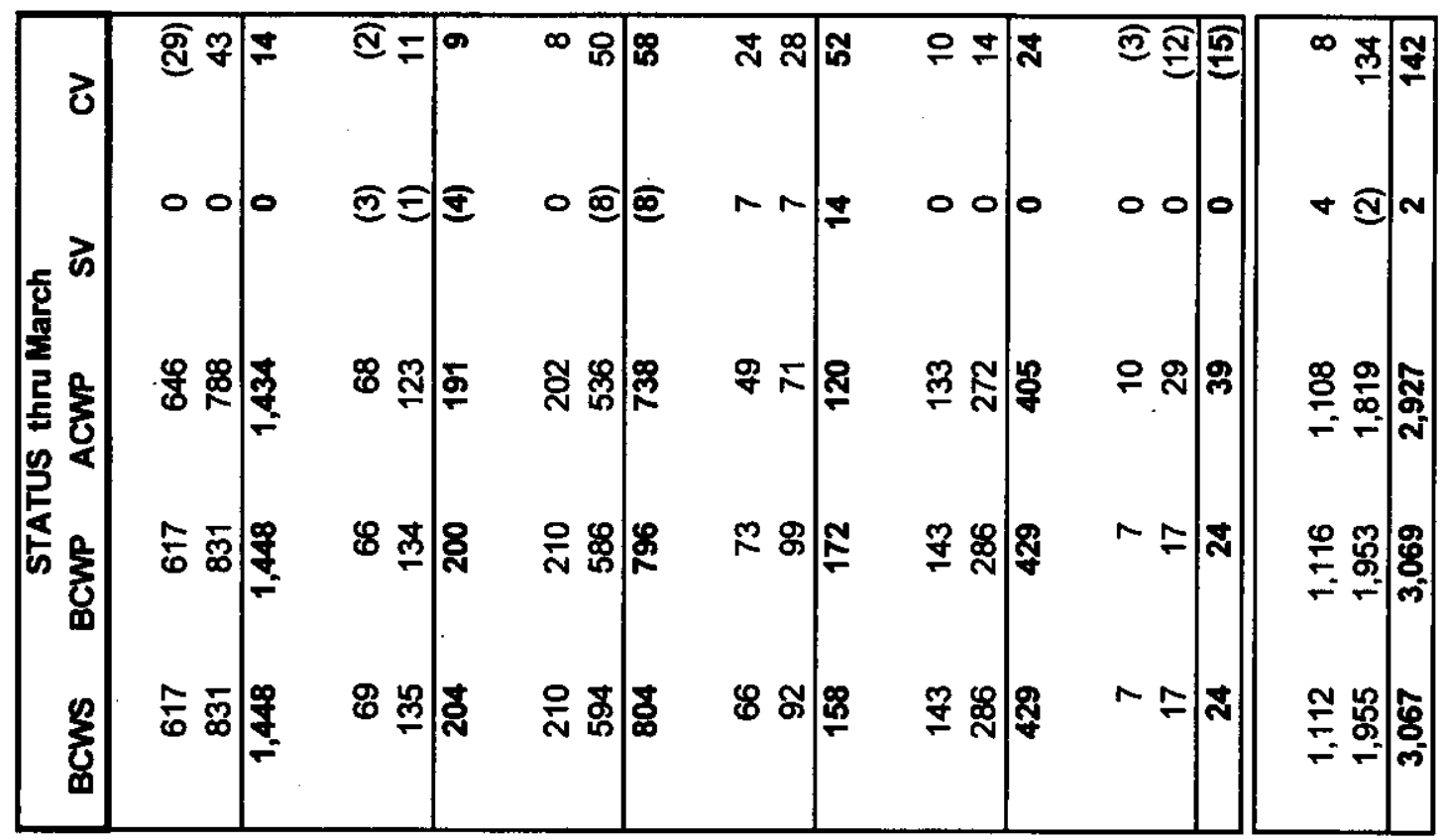

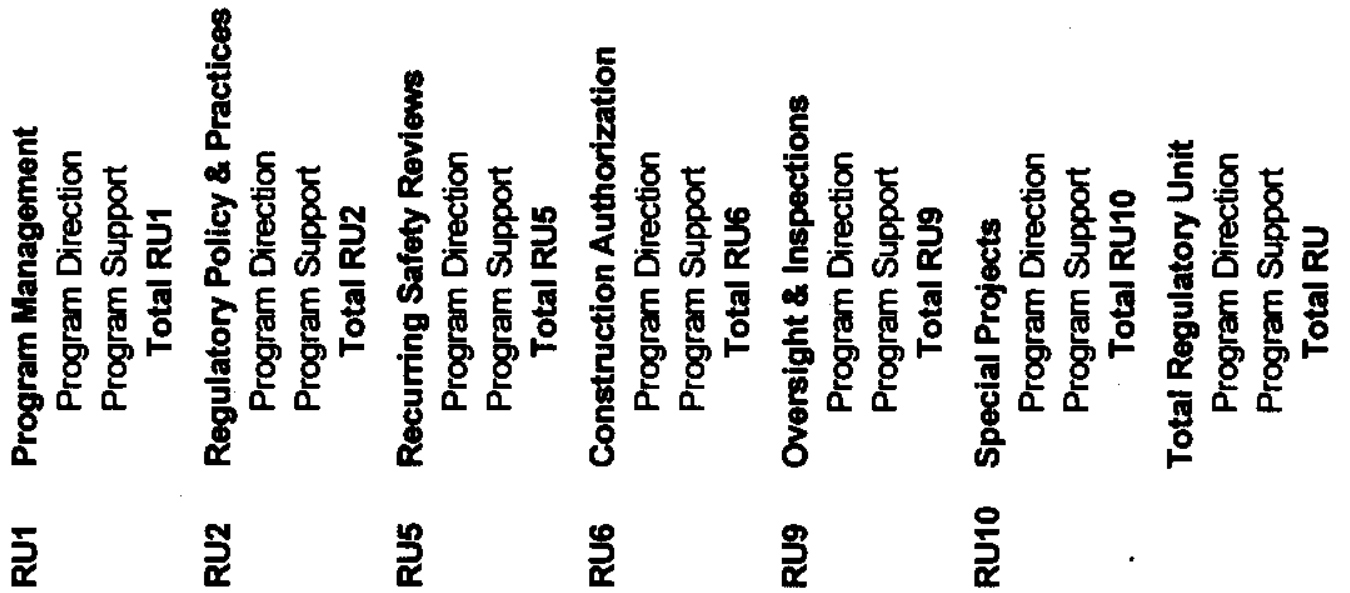


:

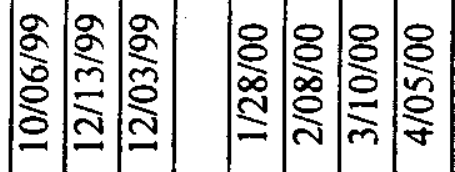

起紧

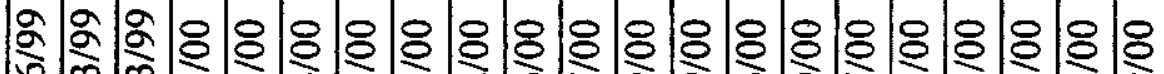

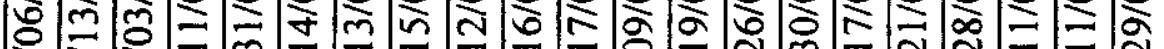

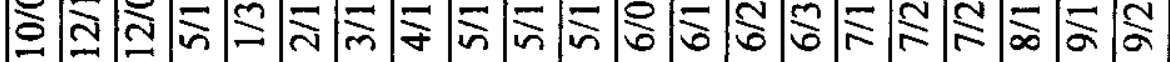

\section{呢}

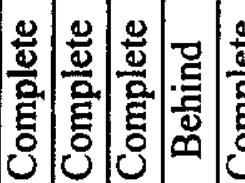

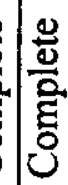

$\frac{2}{20}$

证

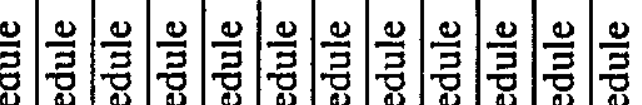

兽 రิ

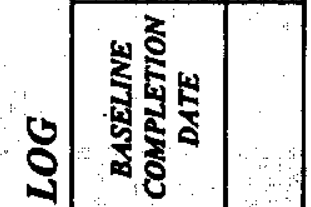

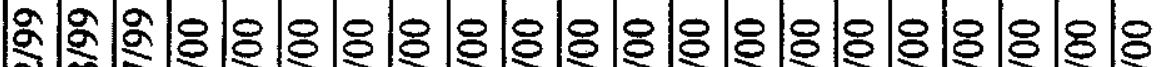

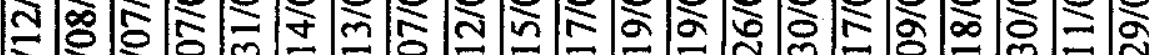

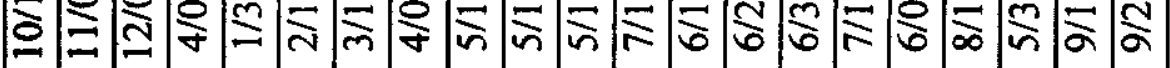

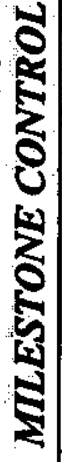

బิ)

$\frac{2}{2}$

है

3

है

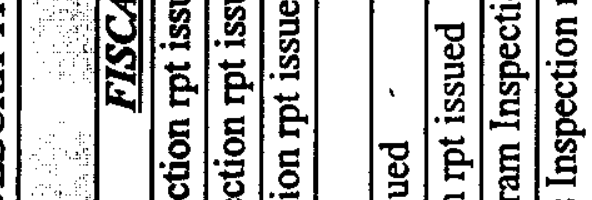

尊

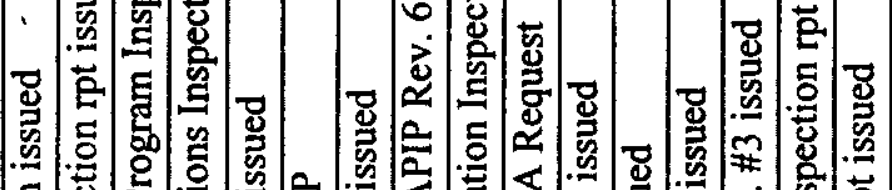

क्⿹

Б)

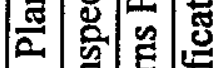

䟫

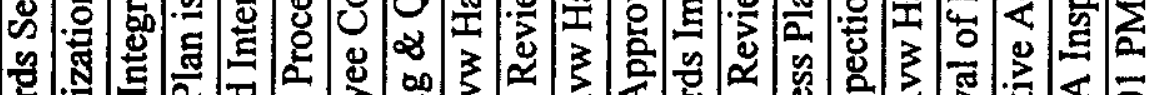

要

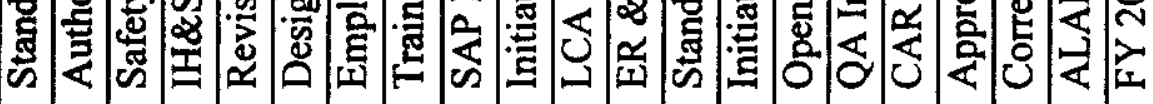

约

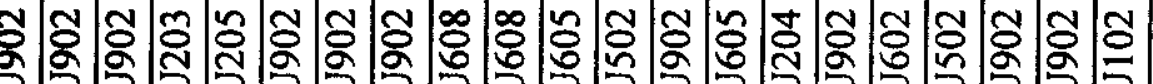

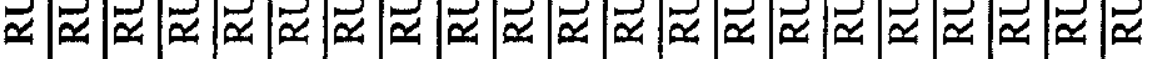

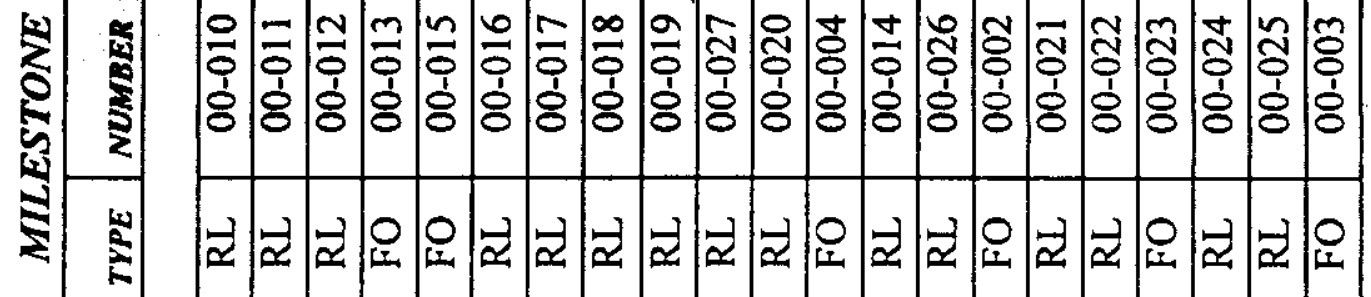



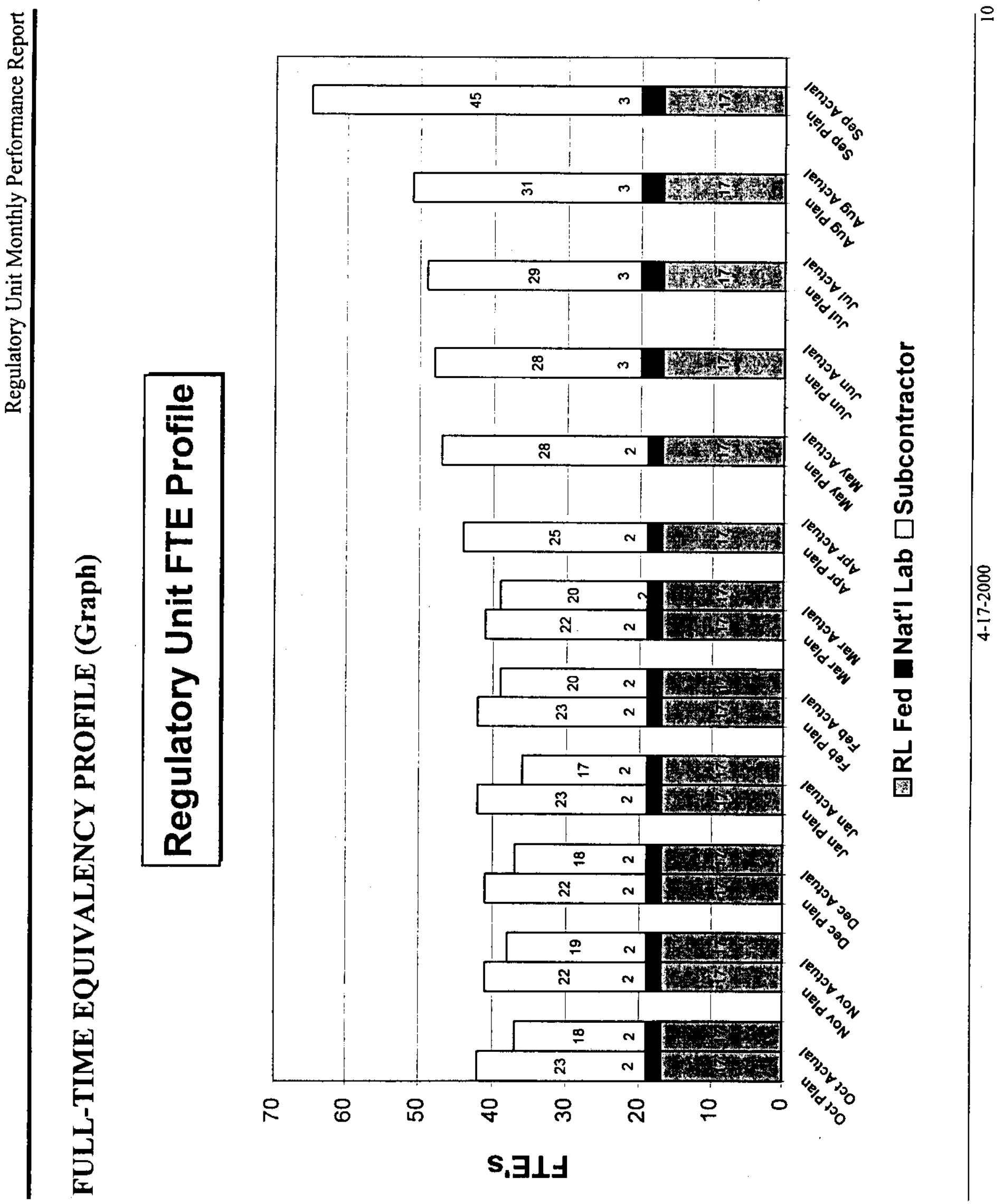

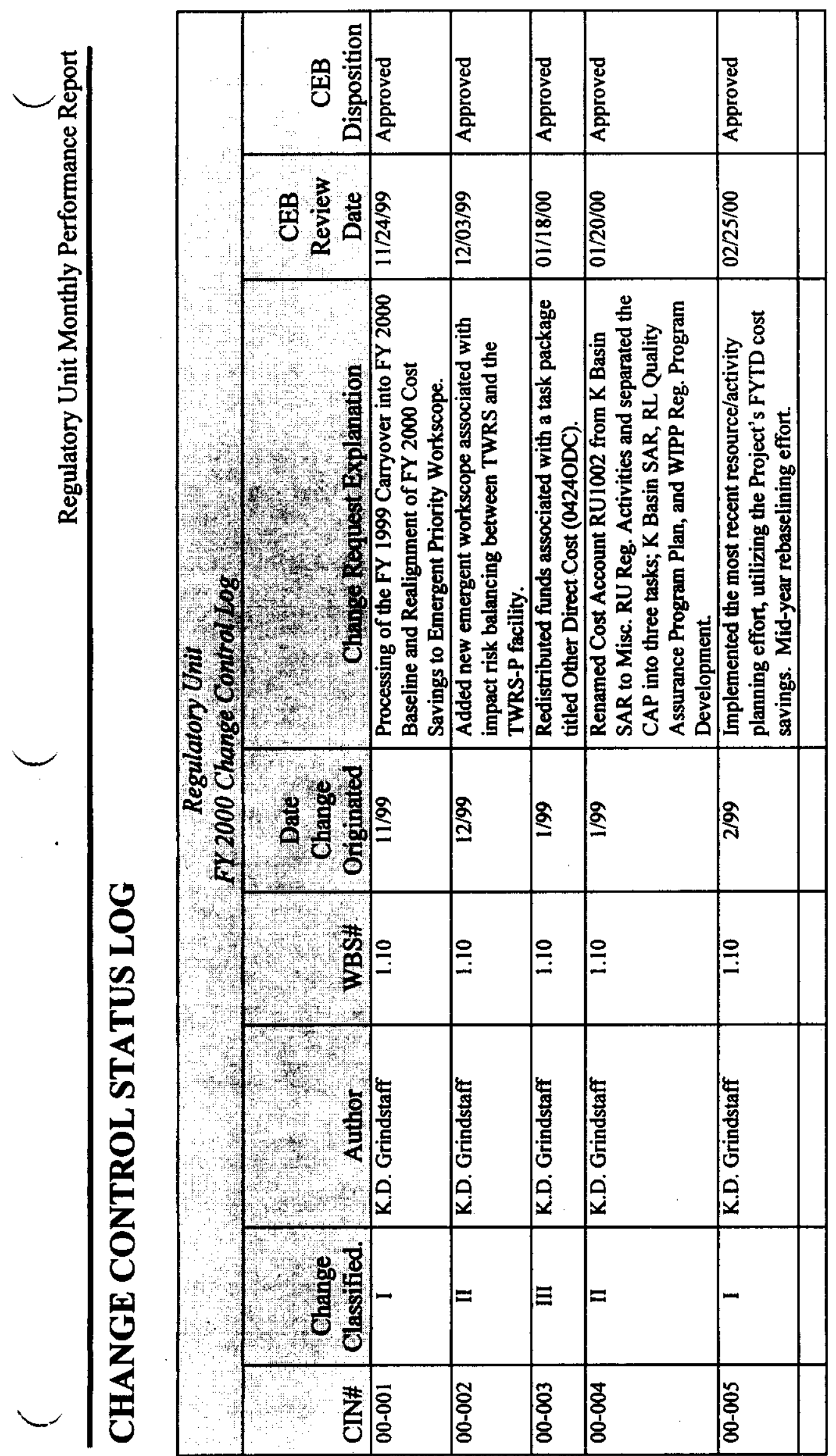
Actual cost of work performed (ACWP): The actual cost incurred and applied or distributed for the work performed within a given time period. It includes all labor categories, material, any other direct costs, subcontract work, and function overhead.

Approved baseline: The budget authorized to perform the workscope that has been agreed upon by the customer and the contractor(s). It is portrayed in the Multi-Year Work Plan with all approved changes. This baseline may or may not be fully funded, and could be more or less than the compliance baseline.

Budget at completion (BAC): The sum of budgets established to complete a program and/or project or any component of a program and/or project.

Budgeted cost of work performed (BCWP): The value for completed work measured in terms of the planned budget for that work. It is synonymous with earned value.

Budgeted cost of work scheduled (BCWS): The time-phased budgeted value of work scheduled to be accomplished over a given time period. The BCWS for a total cost account through its entire period of performance is equal to the BAC for the cost account.

Carryover Workscope: The estimated dollar amount of the workscope that was not completed during the fiscal year and which will be carried over and completed in the next fiscal year.

Compliance baseline: The budget that is required to perform the workscope necessary to be in compliance with State and Federal regulations, enforceable agreement milestones, and DNFSB milestones. The level of activity required to be in compliance assumes sufficient funding. Note: Because approved baselines are considered to be compliant, this column will likely be eliminated.

Contract Inherited: The assumed budget for the planned scope of work at the time a new contract is signed by the company responsible for performing the work.

Cost variance (CV): The difference between $B C W P$ and $A C W P(C V=B C W P-A C W P)$. At any time, it shows whether the work actually performed has cost more or less than the amount budgeted for the same work.

Cost Performance Indicator (CPI): The CPI is the ratio of $\mathrm{BCWP}$ to $\mathrm{ACWP}$, or (BCWP/ACWP).

Earhed value (EV): The periodic, consistent, and objective measurement of work performed in terms of the budget planned for that work. The EV is synonymous with the BCWP and it is compared to the BCWS to obtain schedule performance and to the ACWP to obtain cost performance. 


\section{GLOSSARY (CONTINUED)}

Estimate at completion (EAC): Cost allocated to the work breakdown structure element to date, plus the estimate of costs for authorized work remaining. Authorized work remaining includes any undistributed budget.

Fiscal Year Spending Forecast (FYSF): The estimated total that will be spent from October through September (current Fiscal Year).

Funding carryover and new Budget Authorization (BA): This funding represents both the funding allocated to perform workscope planned in the prior fiscal year, not completed, and approved to be performed in the current fiscal year, as well as new BA to perform the approved baseline workscope.

Funding target: The level of funding that is anticipated (as a result of the Integrated Priority. List process) in a given Fiscal Year based on an assumed funding level for the Site.

Multi-Year Work Plan - 10/1/XX: The Project's approved cost/schedule/technical baseline at the beginning of the fiscal year.

Project Execution Module (PEM): The Project Execution Module (PEM) of the Integrated Planning, Accountability, and Budgeting System-Information System (IPABS-IS) replaces the Progress Tracking System (PTS) as EM Headquarters' centralized system for reporting financial, milestone, performance, and other execution-year information for PBSs, sub-PBSs, TTPs, and line item construction projects. In addition, this module collects mid-year and year-end actual performance information against the agreed upon management commitments for the current execution year.

Schedule Performance Indicator (SPI): The SPI is the ratio of BCWP to BCWS, or (BCWP/BCWS).

Schedule variance (SV): The difference between BCWP and BCWS (SV = BCWP - BCWS). At any time, or for a given period of time, it represents the difference between the planned dollar value of work actually accomplished and the value of the work scheduled to be accomplished.

Work breakdown structure (WBS): A product-oriented family tree division of real estate, hardware, software, services, and data products that organize, define, and display all of the work to be performed in accomplishing the program and/or project objectives. 